U. S. DEPARTMENT OF THE INTERIOR

U.S. GEOLOGICAL SURVEY

\title{
Mineral resource assessment of selected nonmetallic and metallic resources of the Coconino National Forest, Arizona
}

by

James D. Bliss ${ }^{1}$

Open-File Report

$97-486$

This report is preliminary and has not been reviewed for conformity with U.S. Geological Survey editorial standards or with the North American Stratigraphic Code. Any use of trade, product or firm names is for descriptive purposes only and does not imply endorsement by the U.S. Government.

${ }^{1}$ U.S. Geological Survey, Tucson, Arizona 


\section{EXECUTIVE SUMMMARY \\ Assessment of selected nonmetallic and metallic resources of the Coconino National Forest, Arizona}

\section{General}

-The Coconino National Forest (CNF), located in the south-central Colorado Plateau, is an area with few base- and precious-metal mineral deposits.

-Demand for aggregate is increasing with population growth occurring in Flagstaff, Sedona, and Verde River Valley. Finding and establishing new sources of materials is a likely key future issue to be faced.

\section{Industrial Minerals}

- Scoria and cinder are unconsolidated and therefore easily mined for cinder block fabrication.

- The best sources of limestones for cement fabrication are the Redwall Limestone and the Martin Formation.

-Known gypsum deposits have grades comparable to those in production, but the deposits are small; future deposits will most likely be found in the Coconino and Moenkopi Formation.

-Industrial minerals associated with lake deposits include halite, sodium sulfate, diatomite, bentonite and various types of clays

\section{Aggregate}

-Sand and gravel deposits are scarce due to the types of bedrocks present.

- The future sources for aggregate are the Redwall Limestone, the Martin Formation, and younger basalts. Outcrops of the Redwall and Martin are either few and (or) problematic; the best source may be the more widely available younger basalts.

\section{Metals}

- Manganese is the only metal with an appreciable presence in the CNF albeit in limited amounts.

- Sources of base and precious metals are like to be from undiscovered remnants of solution-collapse breccia pipe uranium deposits. These small tonnage $(<11,000 t)$ deposits do not have uranium reported in production. 


\section{TABLES}

1 Grade requirements for lightweight aggregate for structural concrete, in percent (ASTM C 330) $\quad 44$

2 Grade requirements for lightweight aggregate for concrete masonry units, in percent (ASTM C 331) 45

3 Grade requirements for lightweight aggregate for insulating concrete in percent (ASTM C 332) $\mathbf{4 6}$

\section{FIGURES}

1 Location of the six ranger districts of the Coconino National Forest (CNF), Arizona 47

2 Location of selected deposits, prospects, and occurrences recorded in MRDS as of May 22, $1995 \quad 48$

3 Distribution of uses of pumice and pumicite in the United States in 1993

4 Degradation of Quaternary and Tertiary basaltic rocks extracted from quarries in Coconino and Yavapai Counties, Arizona ( $N=13)$, and New Mexico $(\mathrm{N}=6)$ as measured by the Los Angeles wear test (500 rotations) $\mathbf{5 0}$

5 Degradation of unconsolidated cinders, clinkers, and other Quaternary and Tertiary basaltic material extracted from pits in northern Arizona as measured by the Los Angeles degradation test (500 rotations) $\mathbf{5 1}$

6 Probable resistance of rhyolitic rocks in CNF to degradation by abrasion and impact as measured by the Los Angeles degradation test. Based on rhyolites found in New Mexico $\mathbf{5 2}$

7 Probable resistance of rocks from 18 quarries and pits in the Kaibab Formation in, or adjacent to, the CNF 53

\section{ABBREVIATIONS USED}

AASHTO American Association of State Highway and Transportation Officials

ADOT Arizona Department of Transportation

ASTM American Society for Testing \& Materials

CNF Coconino National Forest

At feet

g/t

ha

$\mathrm{km}^{2}$

m

MRDS Mineral Resource Data System, See figure 2 for locations, grams per metric ton hectares square kilometers meter Appendix $\mathrm{A}$ for list of records sorted by commodities or byproduct

NF commodities and Appendix B for full record listing.

PI National Forest

$\mathrm{ppb}$ plastic index

RD parts per billion

t Ranger district

ton metric tons unknown, but likely short ton 


\section{Appendices}

A. List of MRDS records (see Appendix B which follows) sorted by commodities or byproduct commodities including MRDS sequence numbers 54

B. Description of deposits, prospects and occurrences of selected minerals found in and adjacent to the CNF and as reported in the Minerals Resources Data System (MRDS) as of May 22, $1995 \quad 55$ 


\section{CONTENTS}

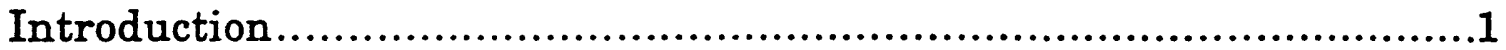

Industrial Minerals .................................................................

Introduction ...............................................................

Marine carbonate rocks .............................................3

Background.....................................................

Geology ….......................................................

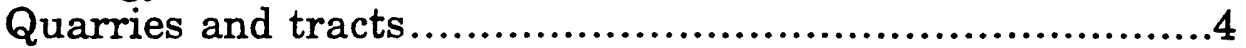

Resource estimate status ...................................5

Marine and lacustrine environments.............................5

Gypsum ........................................................

Background.............................................5

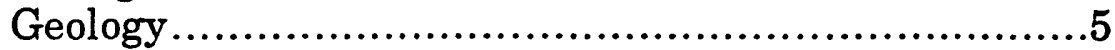

Models .................................................6

Deposits and tracts...........................................6

Resource estimate status ..............................

Lacustrine halite, sodium sulfate, and brines .................

Background ..............................................

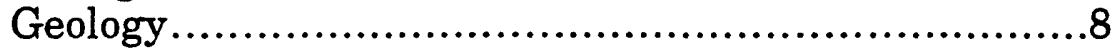

Models................................................... 8

Deposits and tracts...........................................8

Resource estimate status ..............................9

Diatomite .................................................... 9

Pliocene and Miocene clays ...................................... 9

Lacustrine limestone...............................................9

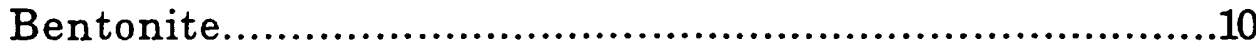

Sandstones ...........................................................

Volcanic rocks...............................................................10

Scoria, cinder, pumice and pumicite..........................11

Background..............................................11

Horticulture and landscaping .........................12

Stone washing laundries ...............................12

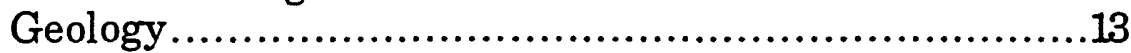

Known pits.................................................13

Definition of permissive areas ..........................14

Models....................................................14

Resource estimate status ..............................14

Basalt and related rocks..........................................15

Quaternary to Recent clays...........................................15

Other industrial minerals............................................16

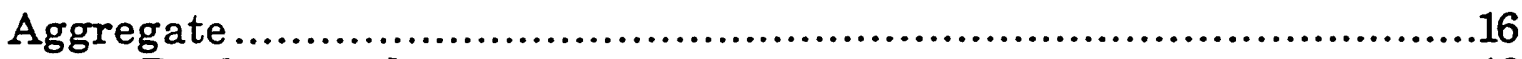

Background...........................................................

Geotechnical considerations.........................................17

Surficial alluvial aggregate..........................................19

Introduction ...................................................

Verde Valley study.................................................20

Soils .............................................................20

Sources of impurities...............................................21 
Alluvium characteristics inherited from bedrock sources ...........22

Background..............................................................................22

Basaltic volcanic rocks...........................................................22

Silicic volcanic rocks....................................................................22

Verde Formation......................................................................22

Moenkopi Formation ..................................................................22

Kaibab Formation ..................................................................22

Toroweap Formation and Coconino Sandstone..................22

Supai Formation ......................................................................23

Redwall and Martin Limestone............................................23

Tonto Group (Tapeats Sandstone only). ..............................23

Precambrian Schist................................................................23

Sources of crushed stone for construction and riprap ...............................23

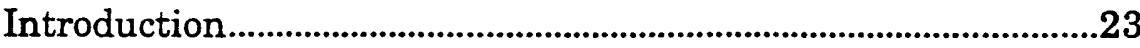

Basaltic volcanic rocks..........................................................................23

Silicic volcanic rocks .............................................................................26

Verde Formation ................................................................................27

Chinle Formation......................................................................................27

Moenkopi Formation..........................................................................27

Toroweap Formation and Coconino Sandstone..............................27

Kaibab Formation .............................................................................27

Supai Formation................................................................................28

Redwall Limestone............................................................................28

Martin Limestone ..........................................................................28

Tonto Group (Tapeats Sandstone only) ..........................................28

Precambrian schist..........................................................................29

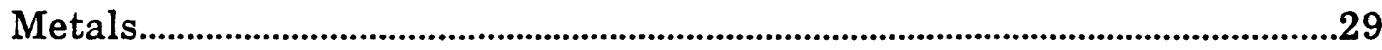

Introduction .................................................................................................29

Strata-bound manganese.............................................................................29

Replacement iron deposits ...........................................................................30

Remnants of solution-collapse breccia pipe uranium deposits..............30

Sediment-hosted $\mathrm{Cu}$ deposits, redbed type .................................................31

Other metallic deposit types..............................................................................32

Reference cited.......................................................................................................... 


\section{Introduction}

The Coconino National Forest (CNF), Arizona, contains approximately 814,000 hectares (ha) (2 million acres) in six Ranger Districts (RDs) as shown in fig. 1. The purpose of this assessment is to provide information useful to Forest Service land managers primarily concerning the quantity of metals and materials in deposits yet to be discovered in the CNF. Of course, known deposit types in or adjacent to the $\mathrm{CNF}$ are useful in identifying appropriate deposit types. Two different mineral resource assessment techniques are used: one for metals and industrial minerals and a second for uranium.

While both are types of quantitative mineral resource assessments, the first type requires mineral deposit models like those found in Cox and Singer (1986) and Bliss (1992). The procedure is described by Singer and Ovenshine (1979) and Singer and Cox, (1988) and allows predictions of how much material remains in undiscovered deposits at different levels of certainty (Root and others, 1992; Spanski, 1992). The former U.S. Bureau of Mines (BOM) also successfully used USGS assessment results in their analysis of economic potential of future mineral development within an area (the East Mojave National Scenic Area, California (U.S. Bureau of Mines, 1992) and Kootenai National Forest (NF), Idaho and Montana (Gunther, 1992)). Grade and tonnage models are needed as well as an estimate of numbers of undiscovered deposits. Deposit types lacking grade and tonnage models cannot be assessed.

The assessment of uranium in solution-collapse breccia pipe uranium deposits is handled differently. The procedure used and the assessment results are found in a previous report by Bliss and Pierson (1994). The predicted undiscovered uranium from this deposit type does not represent uranium endowments additional to those reported by Finch and others (1990), but they suggest what portion of their endowment is found within the Coconino NF, Arizona (Bliss and Pierson, 1994). One site (Appendix B, MRDS No. 101--see below for explanation of abbreviation and number) was also noted during this part of the assessment (and not noted in Bliss and Pierson, 1994) may have evidence of solution-collapse breccia pipe uranium deposits in favorable area type B (Finch and others, 1990).

Industrial minerals have been and are likely to be the primary type of mineral commodity produced in the future in the CNF. Modeling industrial mineral deposit types is not as extensive as needed (Orris and Bliss, 1991; Orris and Bliss, 1992). New types of mineral deposit models may be required (Orris and Bliss, 1989). Unfortunately, mineral deposit models are not available for most of the industrial mineral commodity types found in the CNF. Flagstone is an important industrial mineral with a long production history in the adjacent Kaibab NF. An attempt was made to develop models for flagstone in an assessment of the Kaibab NF (Bliss, 1993), but it was unsuccessful due to poor and incomplete data.

Data about mineral deposits found in or adjacent to the CNF have come from various sources. A general source for mineral deposit data is the Mineral Resource Data System (MRDS), a world-wide computer 
database with locality and commodity data. Additional sources for industrial minerals include Phillips (1987) and Houser (1992). Appendix A contains a selection of some of those records in or adjacent to the CNF as recorded in May, 1995 and are listed on figure 2 using sequence numbers. The records are also ordered by sequence number (upper left hand corner of each page) in Appendix B and specific sites are noted in the text by MRDS sequence number (MRDS No.).

Industrial minerals are covered first, followed by a brief discussion of metallic mineral deposits. Most tracts noted are bounded using stratigraphy or other geologic features which are best seen on regional maps including the following: Weir and others (1989) for the geologic map of the Sedona 30' X 60' quadrangle; Ulrich, and others (1984) for the Flagstaff $1^{\circ}$ by $2^{\circ}$ quadrangle; Moore and others (1960) for other areas of Coconino County; Arizona Bureau of Mines (1958) for other areas of Yavapai County; and Lane (1992, plate 2) for a compiled geologic map of the CNF as a whole. The San Francisco volcanic field is shown on a series of maps including Moore and Wolfe (1987) for the east part, Newhall and others (1987) for the southwest part, Ulrich and Bailey (1987) for the SP Mountain part, Wolfe, Ulrich, and Newhall (1987) for the northwest part, and Wolfe, Ulrich, Holm, and others (1987) for the central part.

A number of other reports applicable to areas in the CNF or adjacent areas were identified during preparation of the assessment. These include Chaffee and others (1996a, 1996b) release of analytical results for rock and stream-sediments collected in the CNF; a number of studies on breccia pipes including Van Gosen and Wenrich (1989), Wenrich (1985), and Wenrich and others $(1986,1988,1989)$; and reports prepared for Roadless area studies including ones for Strawberry Crater (Wolfe and Hahn, 1982; Wolfe and Hoover, 1982, Wolfe and Light, 1987), Fossil Springs (Weir and Beard, 1984; Weir and others, 1983), and West Clear Creek (Ulrich and Bielski, 1983).

Another source was the mineral-resource assessment of undiscovered resources of gold, silver, copper, lead, and zinc in the conterminous United States from 1993 through 1995 (Ludington and Cox, 1996). The assessment consists of probabilistic estimates of the amounts of undiscovered gold, silver, copper, lead, and zinc in conventional types of deposits. The assessment also identified significant known deposits and gave descriptions of the mineral deposit models used. Some tracts, mineral deposits and models used in that assessment are noted briefly here.

Four models of engineering characteristics of aggregate found in the report are prepared and depicted in the same general way as in Cox and Singer (1986). One difference is that each value is identified as belonging to a site, not an aggregate deposit, which needs either an estimate of volume and (or) of geometry. Neither were identifiable in this study. This fact, together with small sample sizes, makes these models preliminary.

This report is organized into three sections: 1) industrial minerals excluding aggregate, 2) aggregate, and 3) metals. The first section contains descriptions of geology, tracts, and other details which will not be repeated in the section on aggregate. Materials not covered elsewhere (for example, 
sand and gravel) will be discussed in greater detail in the aggregate section.

This report lacks figures showing geology. Nearly all tracts identified as permissive for various commodities (or deposit types) are identified by geologic unit(s). Readers who are serious about using the information herein need access to geologic maps (most of which are listed above.)

\section{Industrial Minerals}

\section{Introduction}

Industrial minerals are historically the most important mineral commodities produced in the CNF. This section focuses on industrial minerals with uses other than for aggregate. However, some discussion on the use of materials as a source of aggregate is often unavoidable.

Some industrial minerals are also classified as metals. For example, hematite used as a pigment is considered an industrial mineral while its use as a source of iron makes it a metal. In this assessment, hematite is discusses under the "metals" section.

\section{Marine carbonate rocks}

\section{Background}

Most carbonate rocks are produced for making cement, processed for lime, or crushed for use as aggregate in construction. Limestone or other calcareous rocks make up 75-80 percent of the raw material used to make cement (Harben and Bates, 1984). Limestone is composed of 50 percent or more calcite and dolomite, with calcite greater than dolomite. Ultra-pure limestone contains greater than 97 percent $\mathrm{CaCO}_{3}$; high calcium limestone contains greater than 95 percent $\mathrm{CaCO}_{3}$ (Harben and Bates, 1984). Cement preparation requires not only $\mathrm{CaCO}_{3}$, but also silica, alumina, and iron, which may be contributed by the clay, sand, and chert commonly found in limestones as it is quarried. These components (as well as other materials) need to be added during cement manufacture if they are absent or are insufficient in the limestone. Dolomite is tolerated in limestones up to about 5 percent of the raw material for cement manufacture (Harben and Bates, 1984).

Other uses of limestone or derivative products (e.g., lime) include dimension stone, rip rap, road metal, roofing granules, fillers (paper, asphalt), filters (water treatment), absorbents (gold leaching), ceramics, flux (steel), agriculture, glass, and well drilling fluids (Keith, 1969c; Lefond, 1983). In Arizona the copper industry uses lime in flue gas desulphurisation (O'Driscoll, 1990). Limestone is a common source of 
aggregate wherever it is found. However limestones consisting of about equal parts dolomite and calcite which are used as aggregate in cement are more likely to have alkali-carbonate reactions which may destroy concrete competency (Marek, 1991).

\section{Geology}

As noted in Lane (1992) four limestone units are found in the CNF: 1) Martin Formation, 2) Redwall Limestone, 3) Kaibab Formation, and 4) limestone facies in the Verde Formation. In Arizona the Redwall Limestone of Mississippian age is one of two formations considered best for chemical and industrial use (Keith, 1969c). The limestone is massive, strong, high calcium and low dolomite, with chert in nodules and bands as the chief impurity. This limestone and the Escabrosa Limestone have been the principal source of material for cement production in Arizona (Keith, 1969c).

\section{Quarries and tracts}

Six sites are noted for limestone in MRDS (Appendix A). All sites in CNF are in the Peaks RD. One site (MRDS No. 101) consists of a breccia site containing significant lead and may be an expression of an undiscovered solution-collapse breccia pipe uranium deposit or remnant thereof (see Introduction). Lead may be considered as a possible contaminate of the limestone (probably Kaibab Formation) if the site were to be considered as a source of crushed stone. Limestone and marble are found in several carbonate bodies within the volcanic field on the margins of San Francisco Mountain. Wolfe and others (1987b) included the Redwall Limestone and Temple Butte Formation in the unit which crops out in Little Elder Mountain (probable location of the MRDS No. 76) on the southeast margin, and White Horse Hills, northwest margin, of San Francisco Mountain. Two other sites are noted in the Kaibab Formation (MRDS Nos. 102, 103).

One site (MRDS No. 30) included in Appendix A is an important production site for limestone for use in a cement plant in the Prescott NF (fig. 2) to the west of the CNF. The Clarkdale Cement Plant limestone quarry not only produces from the Redwall Limestone but also from the Devonian Martin Formation. Lane (1992) notes that the limestone provides the necessary $\mathrm{CaCO}_{3}, \mathrm{SiO}_{2}$, and $\mathrm{MgO}$ (which is in dolomitic lenses in the limestone) needed to manufacture cement. Whole-rock analyses for limestone samples are given by Lane (1992, table 2 ).

Three samples of limestone from the Verde Formation, analyzed by the U.S. Bureau of Mines from three sites (Lane, 1992, plate 3, fig. 3), suggest they are suitable for use in cement manufacture (Lane, 1992, table 2). However, the limestone is interbedded with clays, and other materials which would make mining difficult.

Tracts are defined by the outcrop areas of stratigraphic units dominated by carbonates or containing significant carbonate members. All outcrops of the Redwall Limestone in the CNF are permissive. A portion of the Coconino Sandstone may be worked given information about limestone 
quality including impurities (i.e., chert concentrations, dolomite) and detail end-use specifications (cement, aggregate, and so forth).

\section{Resource estimate status}

Limestone is one of a number of bedded industrial mineral deposit types that lack models or strategies for quantitative assessment. Therefore, an estimate of undiscovered limestone resources is not available.

\section{Marine and lacustrine environments}

\section{Gypsum}

\section{Background}

Gypsum, or hydrous calcium sulfate $\left(\mathrm{CaSO}_{4} \cdot 2 \mathrm{H}_{2} \mathrm{O}\right)$, is the most abundant naturally occurring sulfate (Harben and Bates, 1990). Upon loss of water gypsum becomes the mineral anhydrite $\left(\mathrm{CaSO}_{4}\right)$. Use of anhydrite is minor when compared to gypsum although neither mineral is found without the other (Appleyard, 1983). Unfortunately, currently unusable anhydrite represents the larger part of the world's extensive reserves of these sulfates (Appleyard, 1983). Calcined gypsum $\left(\mathrm{CaSO}_{4} \cdot 1 / 2 \mathrm{H}_{2} 0\right)$ or plaster of Paris is an important product as a component of plasterboard and accounts for 70 percent of gypsum consumption (Harben and Bates, 1990). Harben and Bates (1984, p. 130) also notes that "uncalcined gypsum is used as a retardant in cement; as a fertilizer; as a filler in paper, paint, and toothpaste; and in the production of gypsum muds for oil well drilling." Due to the wide availability of gypsum, only readily accessible deposits at the surface are being worked. Strip mining is the common extraction method, with some operations exceeding $50 \mathrm{~m}$ in depth (Raup, 1991). Because transportation is a major contributive cost, proximity to infrastructure and markets is critical in deciding if a deposit will be worked. Gypsum and anhydrite constitute the largest known reserve of sulfur, although it is largely untapped and is currently an uneconomic source.

\section{Geology}

Gypsum and anhydrite occur as evaporites identified in rocks of Silurian age through Quaternary age (Appleyard, 1983). The proportion consisting of anhydrite increases with geologic age of the enclosing rock. Thus, younger deposits are more likely to be worked because they contain more gypsum. Gypsum is commonly found associated with other evaporites. Due to its high solubility, primary gypsum deposits are subject to considerable post-depositional modification, recrystallization, and remobilization. 


\section{Models}

Two broad types of bedded gypsum deposits are recognized for modeling purposes: marine evaporite gypsum (Raup, 1991) and lacustrine gypsum (Orris, 1992c). Both types have permissive geology in the CNF. The descriptive model by Orris (1992c) suggests that most lacustrine gypsum deposits develop in closed or nearly closed continental basins (usually fault controlled) under semiarid to arid conditions. The descriptive model by Raup (1991) notes that marine gypsum deposits develop from the evaporation of sea water in marginal marine basins.

The preliminary grade and tonnage model by Orris (1992e) for marine gypsum deposits is based on data from 14 entities that include data from a mix of districts, areas, and single deposits. Ninety percent of the deposits have a size equal to or greater than 14 million $t ; 50$ percent have a size equal to or greater than 280 million t; and 10 percent of the deposits have a size equal to or greater than 5.6 billion $t$ (Orris, 1992e, fig. 35). Ninety percent of the deposits have a gypsum grade equal to or greater than 82 percent; 50 percent have a gypsum grade equal to or greater than 91 percent; and 10 percent of the deposits have a gypsum grade equal to or greater than 99.8 percent (Orris, 1992e, fig. 36).

The preliminary grade and tonnage model by Orris (1992c) for lacustrine gypsum deposits is also based on data from 14 entities. Ninety percent of the deposits have a size equal to or greater than 0.78 million t; 50 percent have a size equal to or greater than 14 million t; and 10 percent of the deposits have a size equal to or greater than 247 billion $t$ (Orris, 1992c, fig. 35). Ninety percent of the deposits have a gypsum grade equal to or greater than 74 percent; 50 percent have a gypsum grade equal to or greater than 85 percent; and 10 percent of the deposits have a gypsum grade equal to or greater than 96 percent (Orris, 1992c, fig. 36). Lacustrine deposits tend to be both smaller and of lower grade than those for marine deposits.

\section{Deposits and tracts}

Two units found in the CNF contain evaporites and are, thus, permissive for marine gypsum deposits--Permian Coconino Sandstone and the Triassic Moenkopi Formation. The Toroweap Formation is commonly included with the Coconino Sandstone.

It is the Harrisburg Member of the Coconino Sandstone which contains evaporites. Gypsum, along with dolostone, sandstone, redbeds, chert, and minor limestone comprise the sequence (Hopkins, 1990). The member thickens to the west (up to $85 \mathrm{~m}$ ) with significant bedded gypsum present. In fact, gypsum is mined from the Harrisburg member west of Las Vegas, Nevada at the Blue Diamond Hill Mine (Hopkins, 1990). A number of undeveloped occurrences and at least one gypsum mine have been identified in either the Coconino Sandstone and (or) Toroweap Formation in northwest Arizona (Keith, 1969b). To the best of my knowledge, no significant amounts of gypsum have been identified in the Harrisburg Member in the CNF. However, the Coconino Sandstone and Toroweap Formations are permissive for bedded gypsum. 
Irregular gypsum lenses totaling $330,000 \mathrm{t}$ of material at a grade of 97.5 percent gypsum have been described by Keith (1969b) in the Moenkopi Formation (Keith, 1969b; table 31). This tonnage is much smaller than the size distribution of deposits used in the grade and tonnage model by Orris (1992e); however, the gypsum grade in this deposit is within the grade distribution of the grade and tonnage model (Orris, 1992e; fig. 36). No significant amounts of gypsum have been identified in the Moenkopi Formation in the CNF. However, as noted previously, all parts of the Moenkopi Formation are permissive for bedded gypsum.

Lacustrine gypsum is found in the Verde Formation of Pliocene and Miocene ages (Weir and others, 1989) particularly in an area of $190 \mathrm{~km}^{2}$ of evaporites extending about $16 \mathrm{~km}$ northwest, and $10 \mathrm{~km}$ southeast of Camp Verde (fig. 1) in the Verde basin (Twenter and Metzger, 1963, fig. 24). Gypsum in the Verde Formation has been mined at the Larson quarry located in a sequence of evaporites several square kilometers in area interbedded with mudstone and volcanic ash which can be $100 \mathrm{ft}(30 \mathrm{~m})$ thick (MRDS No. 1). Lane (1992) notes that the material mined is about 7075 percent gypsum. This suggest that the deposit is low grade within the context of the grade and tonnage model of lacustrine gypsum (Orris, 1992c). Also located in these evaporites is the Wingfiled-Mcledd gypsum deposit (MRDS No. 15) where gypsum was produced for use in agriculture. Another gypsum occurrence (MRDS No. 14) was noted near the Camp Verde Gypsum property (MRDS No. 20) and as part of the stratigraphic sequence at the Verde River Deposit (MRDS No. 16). Several other sites in the Verde Formation are noted for gypsum (MRDS No. 16, 21). For assessment purposes, these sites are discovered gypsum deposit(s). Perhaps the whole sequence exposed at the surface may be considered a deposit partially worked within the context of deposits described in the grade and tonnage model (Orris, 1992c). The Verde Formation is considered to be the permissive area for lacustrine gypsum.

\section{Resource estimate status}

No estimate of undiscovered deposits of either type was made. Marine gypsum deposits like those in the grade and tonnage model are large but it is unknown how extensive (or exhaustive) exploration has been for bedded gypsum deposits in the CNF. Existing data suggests that the situation for lacustrine gypsum is more promising than for the marine type. Grade may be a problem if the worked portion at Larson Quarry represents the best quality of material available. However, the presence of undiscovered deposits without outcrop for both types cannot be discounted.

\section{Lacustrine halite, sodium sulfate, and brines}

\section{Background}

Halite $(\mathrm{NaCl})$ or salt is used by the chemical and food industries and in snow and ice removal (Orris, 1992d). Lacustrine halite becomes important only locally when marine deposits are unavailable, as in Australia (Orris, 1992d). Halite is extracted by conventional mining to depths of $100 \mathrm{~m}$; and by solution mining at depths greater than $500 \mathrm{~m}$ (Orris, 1992d). Proximity 
to infrastructure and markets is critical in deciding if a deposit will be worked, because transportation is a major contributive cost. Halite need not be directly mined but may also be extracted from natural brines and sea water.

Most sodium sulfate produced is used in the manufacture of detergents, paper, and glass (Harben and Bates, 1990). Two minerals, thenardite $\left(\mathrm{Na}_{2} \mathrm{SO}_{4}\right)$ and mirabilite $\left(\left(\mathrm{Na}_{2} \mathrm{SO}_{4} \cdot \mathrm{H}_{2} \mathrm{O}\right)\right.$, commonly called Glauber's salt, are commercially important. Sodium sulfate is also extracted from brines.

\section{Geology}

Lacustrine halite occurs as either bedded or massive bodies in continental basins (Orris, 1992d). Most deposits are late Tertiary or Quaternary. Basins are closed or semi-closed and contain sediments and evaporites developed under arid conditions. Due to high solubility, halite deposits are subject to considerable post-depositional modification, recrystallization, and remobilization. Sodium sulfate is common in alkali lakes and is found with other evaporites including halite and gypsum.

\section{Models}

Only the preliminary descriptive model by Orris (1992d) without an associated grade and tonnage model is available for lacustrine halite; however a constituents model is available for sodium carbonate (sulfate, chloride) brines (Orris, 1992a). These are brines considered sufficiently concentrated to be a source of their contained constituents (G.J. Orris, 1995, oral commun.) Ninety percent of the brines have a sum of $\mathrm{Na}_{2} \mathrm{CO}_{3}$, $\mathrm{Na}_{2} \mathrm{SO}_{4}$, and $\mathrm{NaCl}$ constituents equal to or greater than $6,400 \mathrm{ppm} ; 50$ percent have a sum equal to or greater than $33,000 \mathrm{ppm}$; and 10 percent of the brines have a sum equal to or greater than 220,000 ppm (Orris, 1992a, fig. 42-44). Neither a descriptive model nor a grade and tonnage model is available for sodium sulfate minerals.

\section{Deposits and tracts}

Lacustrine halite is found in the Verde Formation of the Pliocene and Miocene ages (Weir and others, 1989) particularly in an area of $190 \mathrm{~km}^{2}$ of evaporites extending about $16 \mathrm{~km}$ northwest, and $10 \mathrm{~km}$ southeast of Camp Verde (fig. 1) in the Verde Basin (Twenter and Metzger, 1963, fig. 24). Halite in the Verde Formation has been mined, along with sodium sulfate, at the historic Camp Verde Mine (MRDS No. 21, Appendix A; fig. 2). The Verde Formation is a sequence of evaporites several square kilometers in area interbedded with mudstone and volcanic ash which can be as much as $100 \mathrm{ft}(30 \mathrm{~m})$ thick.

Not only are halite deposits recognized, but brines are also present. A saline water well near Camp Verde (MRDS No. 11) contains 177,000 ppm dissolved solids, predominantly sulfate and chloride. This well appears to be consistent with the concentrations noted in the brine model by Orris (1992a). This would still be true if only a half of the soluble solutes present are the same as those in the model. A sample collected in 1959 from a ground-water well about $4 \mathrm{mi}(6 \mathrm{~km})$ southeast of Camp Verde along West 
Clear Creek was reported to contain 90,300 ppm dissolved solids largely dominated by sodium (+ potassium) and sulfate (Twenter and Metzger, 1963, table 10). This well may also be a source of usable brines (MRDS No. 31). Detailed chemical analyses are needed for both wells as is an estimate of the size of the brine reservoir. In addition, possible discharge rates are needed.

Lane (1992) notes that a sodium sulfate deposit was mined west of Camp Verde (Camp Verde Salt Mine, MRDS No. 21). Weisman and Mcllveen (1983) describe the deposit as $46 \mathrm{~m}$ thick. It is unusual in that it contained pure mirabilite crystals.

For assessment purposes, these sites at the surface are for discovered halite/sodium sulfate deposit(s). The Verde Formation is considered to be the permissive area for lacustrine halite/sodium sulfate deposits and sodium carbonate (sulfate, chlorite) brines.

Resource estimate status

An estimate of undiscovered lacustrine halite/sodium sulfate deposits was not made, given the absence of a grade and tonnage model. At least one and perhaps two brine reservoirs of unknown sizes are inferred to exist.

\section{Diatomite}

One occurrence of diatomite is reported south of Camp Verde (MRDS No. 16). Lane (1992) cites oral communication (Ed Davidson, Superior Materials) that diatomite is present at the gypsum deposit $6 \mathrm{~km}$ southeast of Camp Verde [most likely Larson Quarry, MRDS No. 1]. Samples examined from various sites in the Verde Formation appear to be of poor quality (Lane, 1992). A descriptive model by Shenk (1991) is available; a grade and tonnage model is not.

\section{Pliocene and Miocene clays}

An unspecified type of clay is noted at the diatomite deposit south of Camp Verde (MRDS No. 16) and near Clarkdale (MRDS No. 23). Brick clay is found north of Clarkdale (MRDS No. 22) and is also suitable for use in cement manufacture. Lane (1992) noted that most clays in the Verde Formation are bentonitic, although Funnell and Wolfe (1964) as cited by Lane (1992) noted that low-expanding, high-calcium montmorillonite is found southeast of Camp Verde. See Lane (1992, table 1) for the chemical and physical characteristics of some clay samples collected in Verde Formation.

\section{Lacustrine limestone}

Three samples of limestone from the Verde Formation were collected by the BOM from three different sites (Lane, 1992, plate 3, fig. 3). The analyses indicate they are suitable for use in cement manufacture (Lane, 
1992, table 2). However, the limestones are interbedded with clay and other materials which will make mining difficult.

\section{Bentonite}

Bentonite found associated with gypsum at the Larson Quarry was used as canal-reservoir sealer and for iron ore pelletization (see MRDS No. 1, Appendix B, for details).

\section{Sandstones}

The Coconino Sandstone and Moenkopi Formation are found in the $\mathrm{CNF}$ and have been a source of sandstones usable for flagging and ashlar. In fact, flagstone (and minor ashlar ${ }^{1}$ ) production from the Coconino Sandstone is an important industry in the Kaibab NF to the west and Prescott NF southwest of the Coconino NF. Models needed for making quantitative predictions about flagstone and ashlar resources have not been developed and the attempts to do so for the assessment of the Kaibab NF were largely not successful. See Bliss (1993) for details and background material which is still valid here but will not be repeated. However, one correction is needed. Extraction of flagging is easier where the sandstone bedding slopes in the same direction as the topographic slope, however, this situation does not seem to have been critical in the siting of most existing quarries.

Minor production of flagging has come from the Moenkopi Formation but the Moenkopi has chiefly been the source of large building blocks and ashlars prior to the 1930's (Keith, 1969e). The Moenkopi does not split easily for flagging. A basal, massive sandstone has provided the best material. Keith (1969e, p. 447) reports that it consists of a "poorly to wellsorted, fine to very-fine grained, lenticular bed, 20 to 40 feet thick." This massive sandstone contains about 80 percent silica, up to 4 percent iron and aluminum oxides, and 13 percent calcium carbonate (Keith, 1969e). Although the stone forms solid blocks for use in buildings, it does not retain sharp lines and angles (Burchard, 1914). Stein (1993) gave a detailed overview of the history of production from a Moenkopi sandstone quarry located three miles south of Flagstaff.

\section{Volcanic rocks}

\section{DEFINITIONS}

Block pumice--a legal definition, includes pumice which is greater than $5.2 \mathrm{~cm}$ in one dimension (Hoffer, 1991).

\footnotetext{
${ }_{1}$ Ashlar are rectangular or square stone blocks usually smooth on two parallel sides commonly used for building facing.
} 
Pumice--light-colored, highly vesicular volcanic glass, commonly of rhyolitic composition; vesicles are fine and uniform; glassy appearance (Harben and Bates, 1990). Fragments greater than $6.4 \mathrm{~cm}$ called lump pumice; 0.4 to $6.4 \mathrm{~cm}$ called pumice (Hoffer, 1991)

Pumicite--shattered pumice consisting of grains, flakes, threads and shard of glass less then $3 \mathrm{~mm}$ in diameter (also called volcanic ash, can have diverse chemistry) (Harben and Bates, 1990)

Scoria--mafic version of pumice, fragments from $0.25 \mathrm{~mm}$ and larger, highly vesicular, red to black pyroclastic material, usually andesitic to basaltic composition; vesicles are coarse and variable; stony appearance (Harben and Bates, 1990).

Volcanic cinder--fragments less than $0.25 \mathrm{~mm}$, highly vesicular, red to black pyroclastic material usually andesitic to basaltic in composition; vesicles are coarse and variable; stony appearance (Harben and Bates, 1990). Fragments of comparable composition that are larger than $0.25 \mathrm{~mm}$ are called scoria (see above).

Scoria, cinder, pumice and pumicite

\section{Background}

Uses of scoria and volcanic cinder (or simply cinder in the discussion below) include those of aggregate, cinder block, concrete, horticulture and landscaping, abrasives, and railroad ballast. Key properties making scoria and pumice valuable in construction are: light weight, insulating ability, high fire resistance, and toughness (Harben and Bates, 1984; Mason, 1994). Pumice has somewhat more specialized uses than cinder. The most important uses of pumice and pumicite are shown in figure 3 . A particularly interesting use is in stone washing laundries particularly of jeans in which lump pumice is used to abrade and soften denim (Scott, 1992, p. 35). Pumice and pumicite are used as an abrasive material for dressing wood or metal and in domestic and industrial cleaning of surfaces (Keith, 1986d). Uses included in "Other" in figure 3 are as an absorbent, dilutent, filter aids, roofing granules, in water treatment, and as a road metal (Bolen, 1994; Osburn, 1982)

Pumice and pumicite are primarily used in the fabrication of building bricks. Construction related uses of pumice and pumicite make up approximately 70 percent of the material consumed annually (Bolen, 1994). However, among materials produced and used as lightweight aggregate (17 to 20 million tons) in 1983 to 1989 in the US, pumice and pumicite accounted for only 2 or 3 percent of the total $(350,000$ to 500,000$)$ according to Mason (1994) who used data from the former BOM. Materials used in lightweight aggregate are notable for having densities of 1.3 to 1.6 $\mathrm{t} / \mathrm{m}^{3}$ when loosely packed as compared to $2 \mathrm{t} / \mathrm{m}^{3}$ and more for crushed stone, sand, gravel, or air-cooled slags. Pumice, pumicite, and scoria with densities between 1.4 to $1.8 \mathrm{t} / \mathrm{m}^{3}$ can be used in lightweight concrete (Mason, 1994). Some pumice is pozzolan. When finely ground, it reacts chemically with lime to form a hydraulic cement at normal temperatures (Smith and Collis, 1993; Prentice, 1990). Pozzolan is sometimes used as 
part of Portland cement to increase sulfate resistance and reduce alkaliaggregate reactions (White, 1991).

Lightweight aggregate must be tested for suitability before they can be used in construction. The dry loose weight should be between 0.881 to $1.12 \mathrm{t} / \mathrm{m}^{3}$ (Mason, 1994). Aggregate requirement for structural concrete is given ASTM C 330. Table 1 lists the grade requirements of this test as fine aggregate, coarse aggregate, or as a combination of the two (Mason 1994). Two other ASTM tests are also applicable, C331 for concrete masonry units (blocks) the grading requirement for which is given in Table 2, and C332 for insulating concrete, the grading requirement for which is given in Table 3 (Mason, 1994; Geitgey, 1994).

Organic or iron oxide contaminants in lightweight aggregate can cause undesirable discoloration in concrete and need to be kept to a minimum. Hydration can cause obsidian fragments to expand and damage cement (Geitgey, 1994). Other impurities may adversely effect product integrity. Clay lumps need to be less than 2 percent by dry weight; loss on ignition should be less than 5 percent except for cinders where loss on ignition should be less than 35 percent (Mason, 1994).

Arizona Department of Transportation (1990) standard specifications do not address lightweight aggregate, perhaps because these types of concretes are unsuitable in highway structures. The Arizona Department of Transportation (1990) does stipulate the Portland-pozzolan cement meet ASTM C 595, but no special test is identified in their specifications for the pozzolan material. Hoffer (1994) noted that pumice (either as raw or calcined nature pozzolan) used in Portland-pozzolan cement should conform to requirements of ASTM C 618-78 which considers compressive strength, water requirement for flow, shrinkage during drying, and effective reduction of alkali reactivity (U.S. Bureau of Mines, 1969; White, 1991). Schmidt (1956) as cited in Geitgey (1994) described using pumice in controlling landslides in highway right of way.

\section{Horticulture and landscaping}

Mason (1994, p. 808) describes that "finer granular pumice is used in potting soils and as a hydroponic growth medium." Pumice helps to increase drainage in soil. Color of the cinder or scoria dictates how it is likely to be used in landscaping. Dark reddish brown material is found in vent areas; it becomes brown to dark gray with iridescent surface coatings at intermediate distances and becomes very dark gray to black in the outer edges of volcanic cone (Osburn, 1982). Color changes are related to a decreasing ferric to total iron ratio varying from 95 percent in the vent area to 5 percent in the outer edges of the cone (Osburn, 1982).

\section{Stone washing laundries}

Pumice functions in two different ways in the preparation of stone washed fabrics--as an abrasive and as an acid-impregnated absorbent. Both soften the garment and give it a worn look (Hoffer, 1994). The three most important physical properties of pumice important in stone washing are absorption capacity, apparent density, and abrasion loss; other factors include moisture content, impregnation rate, surface fines, and coloration 
(Hoffer, 1994). Pumice of different sizes gives different effects. Small fragments produce a more even worn look as compared to that produced by coarser fragments (Hoffer, 1994).

Pumice used as an abrasive is formed into solid blocks, granules, powders or bonded material. As pumice is brittle, wear produces a continuous new crop of fresh cutting edges during use (Mason, 1994). Examples of applications are: cleaning restaurant grills, cleaning tile, or for cosmetic skin removal. Pumice is also found in heavy-duty hand cleaners. (Mason, 1994). Suitability of pumice as a abrasive requires uniformly fine vesicular material several times smaller than the particle size of the surface to which it is applied (Geitgey, 1994). Nonpumice fragments, particularly those harder than the pumice, can cause undesirable scratches, and therefore, should be less than one percent. Less than 0.5 percent is better, as attributed by Geitgey (1994) to Hess (private commun., 1992). Preparation of pumice for abrasives is difficult and timeconsuming; suitable deposits are uncommon and these and others factors make abrasive pumice prices up to 100 times higher than those of pumice used in aggregate (Geitgey, 1994).

Three properties which give pumice a great diversity of uses are low chemical reactivity, high surface area, and high porosity. This allows pumice to have many uses as an absorbent. It can be used as a carrier for pesticides, herbicides, and fungicides among others (Mason, 1994). Mason (1994, p. 808) also notes that "lumps of pumice about $5 \mathrm{~cm}$ in diameter are used in gas grills to absorb grease drippings and reduce flaming." Scoria has been substituted for pumice in this application.

\section{Geology}

Scoria, cinders, and pumice are all products of explosive volcanism. All involve the rapid loss of dissolved fluids from volcanic material on reaching the surface. The distinction between scoria and pumice is based chiefly on composition--mafic volcanic melts yield scoria while siliceous melts yield pumice. When pumice is less than 0.16 inches $(0.4 \mathrm{~cm})$ in diameter, it is called pumicite and can be carried great distances in the atmosphere (Peterson and Mason, 1983). When scoria is less than 1 inch $(2.5 \mathrm{~cm})$ in diameter it is called cinder (Harben and Bates, 1984).

In general, scoria and cinder are deposited near the source volcanic vent. Less dense, finer grained pumice is carried farther away. The extremely fine-grained pumicite can travel thousands of kilometers. Keith (1986d) noted that pumice is chemically comparable to rhyolite, quartz latite, and dacite. Deposits are commonly lenticular and are found interbedded with lava and tuff.

Known pits

Pozzolan, a highly siliceous pumice sand, is recognized at several sites (Appendix A), one of which supplied material for concrete for the Glen Canyon Dam in 1965 (MRDS No. 38) in eastern Peaks RD. About 200,000 short tons of materials was produced (Williams and Zinkl, 1965). 
Definition of permissive areas

Wolfe, Ulrich, and Newhall (1987) and Wolfe, Ulrich, Holm, and others (1987) prepared geologic maps of the northwest part and central part of the field. Newhall and others (1987) mapped the southwest part. These maps all show a portion of the CNF.

A large number of cinder and scoria pits are particularly abundant in the Peaks RD; they also are present elsewhere in the CNF. This material has been, and will continue to be, produced. Cinder and scoria associated with volcanic cones are a resource readily identified if present. The better quality material is usually found in, or adjacent to, the youngest cones, which makes this material easy to discover. In addition, the geometry of unworked cinder cones can be one key to understanding its potential for cinder and scoria (see Improving the assessment of discovered cinder cones). Wind-fall material may not be identified so readily.

In the San Francisco volcanic field (Peaks RD, fig. 2), pumice is likely to occur in major eruptive centers with andesite, rhyolite, and dacite volcanics. Such eruptive centers include: Sitgreaves Mountain, Bill Williams Mountain, and Kendrick Peak. A portion of Kendrick Peak is in CNF; the other eruptive centers are in Kaibab NF. Pumice deposits recognized on the east flank of Bill Williams Mountain (in Kaibab NF) are poor quality as compared to 14 sources of pumice in the United States and the world (Scott, 1992). The high density and low porosity of this pumice makes it suitable only for landscaping and in road construction (Scott, 1992). Areas permissive for pumice are those with rocks of dacite and rhyolite composition.

Models

Models for making quantitative predictions about undiscovered cinder, scoria and pumice resources have not been developed; therefore an evaluation of undiscovered resources is not available. On the other hand, the CNF contains a considerable number of cones with identified cinder and scoria resources that will be exploited before less accessible deposits are considered. While estimates of volume of material in identified cinder cones are possible, models characterizing the chemical and physical properties of scoria, cinders, and pumice for appropriateness for their various uses have not been developed. A model for scoria, cinder and other unconsolidated basaltic material of durability in aggregate is available and described in aggregate section.

Resource estimate status

Osburn (1982) showed that the ratio of height to basal diameter, or the aspect ratio, is usually between $0.1-0.2$ for cinder cones that can be mined. Cones with lower aspect ratios contain more flows. Cones with an aspect ratio greater than 0.2 contain agglutinate blocks which makes extraction difficult (Osburn, 1982). Measuring aspect ratio from topographic maps can help identify which cinder cones should be considered initially as a source of cinder. 
Scott (1992) found that roughly half of the 200 or more cinder cones in the Chalendar and Williams Ranger District in the adjacent Kaibab NF have aspect ratios between 0.1 and 0.2 . Scott (1992) also found that 75 percent of all pits are located on cones with aspect ratios between 0.1 and 0.2 . No systematic relation was found by Scott (1992) between cinder cone composition type and the presence or absence of cinder quarries.

Most of the cinder and scoria in the CNF are associated with identified cinder cones. Some finer-grained material may be located beyond the cones, but represents a small amount of material in comparison with material in identified cones. Some complex cones may be difficult to assess. A portion of each cone can also be expected to contain some vesicular flows and agglutinate fragments that will make extraction difficult (Harben and Bates, 1984).

Basalt and related rocks

The main use of basalt and other dark, fine-grained igneous rocks is as crushed stone in concrete and aggregate. Harben and Bates, $(1984$, p. 63) notes that "basalt is $* * *$ melted and cast into floor tiles and acid-resistant equipment for heavy industrial use." Basalt use as a dimension stone is dependent on fashion. In the past it was not used as dimension stone because it was thought to have a somber appearance (Keith, 1969a). However, dark colored stone has become fashionable and can demand a premium price. Quarrying basalt can be difficult due to its lack of joints and its tendency to blast into irregular sized and shaped blocks. Basalt and related rocks are the highest density material used as aggregate, which precludes shipping it great distances. On the other hand, basalt's high density makes it preferable for other uses where high density is needed, given other rock characteristics are acceptable.

Abundant Tertiary and Quaternary basalts are found in the San Francisco volcanic field, which was active during the Pliocene and Pleistocene (Newhall and others, 1987). Compositionally the material is basalt and basaltic andesite with lesser amounts of andesite, benmoreite, and dacite.

A model developed for assessing basalt and related rock types is found in the section on aggregate. The CNF contains considerable identified basalt and related rocks in accessible outcrops that will be exploited before less obvious resources are considered. Possible suitability of basalt and related rock types as dimension stone in the CNF needs to be addressed and appropriate sampling has to be made in future assessments.

\section{Quaternary to Recent clays}

High silica clay is found adjacent to and likely extends under Roger Lake, $14 \mathrm{~km}$ west-southwest of Flagstaff (MRDS No. 9). Lane (1992) described the clay as a montmorillonite-kaolinite with a high bloating factor possibly suitable in fabrication of lightweight aggregate. Analysis of some of the material is reported as possibly suitable in facia brick, or tile (Lane, 
1992, table 1). An approximate endowment of the Roger Lake deposit is 18 million $t$ (Lane, 1992).

All enclosed basins, with or without lakes, within the San Francisco volcanic field should considered as possible target areas for clay deposits, possibly comparable to the one recognized at Roger Lake. The volcanics in the Roger Lake area are predominantly Pliocene (?) and Miocene basalt flows and vent deposits (Wolfe and others, 1987). Perhaps other basins with the same type and age of adjacent rocks may be particularly suitable for the development of these clays.

Two sites with clay are noted southeast and south of the CNF in the Tonto NF. One is Chris Clay deposit (MRDS Nos. 7) and the other is for Florence Ceramics (MRDS No. 8) which contains kaolinitic clay.

\section{Other industrial minerals}

Additional investigation is needed about some industrial minerals. For example, some geologic environments may be present for several other industrial mineral deposit types that are not considered in this report. This includes lacustrine borates (Orris, 1992b) in the Verde Formation for which there is little direct evidence of mineralization. Extensive exploration for borates in 1870-1880s likely left few promising sites unexamined (G.J. Orris, verbal commun., 1995) although the exploration history of the Verde basin has not been documented. Water wells in the area should also have notable levels of B (perhaps in the $50-100 \mathrm{ppb}$ ) or Li (G.J. Orris, verbal commun., 1995) which may effect the suitability of using the water in agriculture. Twenter and Metzger (1963, p. 95) describe the "water from most wells and springs is generally of a chemical quality for use by plant and animals... [with a] dissolved-solids content *** less than $500 \mathrm{ppm} . "$ Additional checking of spring and well water chemistry is needed, however. The Pliocene and Miocene ages of the Verde Formation, and the presence of contemporaneous volcanism as suggested by locally intertongued basaltic and dacitic pyroclastic deposits (Weir and others 1989) are both characteristics of basins with borates (Orris, 1992b). Given that borate minerals can be fine-grained and often recognizable only by analysis, undiscovered borate deposits cannot be completely discounted.

\section{Aggregate}

\section{Background}

Natural aggregate include both crushed stone and sand and gravel. Processing is commonly limited to crushing, washing and sizing (Langer, 1988). There is a fundamental division in the aggregate classification between that produced by crushing stone and that produced from unconsolidated surface material. Aggregate is subdivided based on grain size. Sand and gravel deposits should consist of at least 25 percent gravelsized (4.76-76.2 $\mathrm{mm}$ ) grains (Langer, 1988). Coarse aggregate include 
grains predominantly greater than sieve No. $4(4.76 \mathrm{~mm})$; most fine aggregate particles are expected to pass a No. 4 sieve (0.187-in square opening, $4.76 \mathrm{~mm}$ ), retained or passed on the intervening sieves, but with little material passing the No. 200 sieve $(0.074 \mathrm{~mm})$. A few particles may be included between the $3 / 8$-in sieve $(9.52 \mathrm{~mm})$ and No. 4 sieve $(4.76 \mathrm{~mm})$ (Huhta, 1991).

These rules define aggregate at the level of a resource base (Harris, 1984) which includes identified (and perhaps undiscovered) material, suitable and unsuitable for extraction and without regard to economics. Cox and others (1986, p. 1) define a mineral deposit as "a mineral occurrence of sufficient size and grade that it might, under the most favorable of circumstances, be considered to have economic potential." For aggregate, the word "grade" may be replaced by "geotechnical characteristics." In some regional studies, available data may only allow description of aggregate in no greater detail than resource base. Perhaps a better general definition is possible if geotechnical details, important to extractors and users, are considered.

\section{Geotechnical considerations}

Use criteria for aggregate can vary from one governmental unit to the next, reflecting local geology, climate and local attitudes concerning aggregate suitability. The intended use for the aggregate is equally important. Suitable aggregate must behave in ways that meet minimum geotechnical criteria (percent fines, grain-size distribution, durability, reactivity) to insure roadways and structures constructed with these materials have acceptable longevity and are within acceptable safety limits. One way to measure aggregate usability is to test and use only aggregate that meet standards defined by ASTM, AASHTO, and by local and state governments. For example, see the Arizona Department of Transportation (ADOT) (1990) standard specifications for road and bridge construction.

Despite the large number of standards in use, some broad generalizations are possible. Review of studies by Zdunczyk (1991), Marek (1991) and Goldman (1994) suggest some general minimum specifications; ADOT standards are given as well if available and are as follows: - soundness -- coarse aggregate should exhibit a reduction of particle sizes of less than 10 percent using ASTM Test C88. ADOT requirements for aggregate in concrete placed above $4,500 \mathrm{ft}$ elevation are that they have a reduction of particle sizes of less than 10 percent using AASHTO T 104.

- hardness and strength -- Los Angeles abrasion (wear) test of coarse aggregate gives a loss of material passing the No. 12 sieve $(1.68 \mathrm{~mm})$ of less than 30 percent using ASTM Test C131. ADOT requirements are a loss of less than 40 percent using AASHTO T 96.

- specific gravity -- should be greater than 2.55 using ASTM Tests C127 and $\mathrm{C} 128$.

- grading -- fine aggregate should contain no more than 45 percent of material between two consecutive standard sieve sizes. ADOT requires coarse aggregate gradation to conform to specifications in 
AASHTO T 43 when tested in accordance with the requirements of Arizona Test Method 201.

- fines -- no more than 5 percent of the material should be less than the No. 200 sieve $(0.074 \mathrm{~mm})$. ADOT requirements are the amount of material passing No. 200 sieve not to exceed 1.0 percent.

- fineness modulus -- a single number index used to report the degree of coarseness or fineness of fine aggregate and computation, as described by White (1991, p. 13-8), as " adding the total percentages, by weight, of an aggregate sample retained on each of a specified series of sieves, and dividing the sum by 100." Lower values indicates a finer material and higher values a coarser material. Fineness modules is important in mix design of portland and asphalt concretes, and should be between 2.3 and 3.1 .

- sand equivalent -- a test as described by Marek (1991, p. 3-39) "to indicate the relative proportion of plastic fines and dust to sand size particles;" the ratio should be no less than 77 percent using ASTM Test D2419.

- absorption--Increase in particle weight should not exceed 3 percent using ASTM Test C127.

These specifications clearly restrict the definition of a sand and gravel deposit and some crushed rocks pits; therefore the size of the aggregate resource base is reduced. For geologists and others examining or assessing sand and gravel deposits for possible consideration as a source of aggregate without use of testing facilities, two general characteristics should be noted:

(1) sand and gravel should make up at least 85 to 90 percent of the deposit. Boulders and cobbles may also be included in this calculation if they can be readily crushed. These criteria are not as stringent as those outlined by Goldman (1994). This is because the aggregate industry currently processes material with 10 to 15 percent fines (Drake, 1995). Increased percentage of fines adds expense during extraction, dredging, hauling and disposal or stockpiling. The single problem shared by nearly all aggregate facilities is the production of unusable fines. Discovering a way to use these fines is one of the biggest challenges facing the aggregate industry.

(2) sand and gravel deposits should be well graded, not well sorted. One of the most commonly held ideas among geologists unfamiliar with the aggregate industry is that well-sorted sand and gravel deposits are best. Only one or two mesh sizes may be represented in a well-sorted deposit. Such deposits are not economical because construction companies need sand and gravel aggregate with a mix of grain sizes as defined by the ASTM and other agencies. These standards stipulate that the material must have an interval of particle sizes within certain tolerances. Therefore, aggregate suppliers seek poorly sorted deposits that have wide range of needed grain sizes in a continuous sequence. These are wellgraded deposits. As the price of aggregate goes up and the number of 
readily available suitable deposits decrease, many producers will become more tolerant of sand and gravel deposits which have more silt or are better sorted. These two criteria represent only a part of the specifications which define usable aggregate.

Aggregate for specific uses, particularly in building and road construction, may require detailed evaluations of the following: fragment geometries, external coatings, impurities, fragment mineralogy and textures, flakiness, amounts of soft/friable fragments, level of hydration, alkali-silica reactivity, other types of chemical reactions, susceptibility to leaching, thermal incompatibility, excess polish and excess shrinkage. Aggregate requirements change from place to place, reflecting different climates and other local conditions. All these factors will need to be considered for modeling given adequate data and expression of assessment needs.

\section{Surficial alluvial aggregate}

\section{Introduction}

Areas that may provide a future supply of surficial alluvial aggregate are identified using three broad criteria: compilation of sites used for past production, geology and geomorphology, and soil surveys.

The qualities of aggregate deposits important to end use has been established by organizations concerned with the durability and stability of roads and others engineering structures. For example, AASHO developed a rating system with seven classes (A-1 to A-7) where A-1 is assigned to soils with the highest bearing strength (i.e., best for subgrade) and A-7 is assigned to soils which have the lowest strength when wet. ASTM has developed a large number of different standards of geotechnical measures for aggregate. The grain size distribution must be well graded. This can be demonstrated using ASTM [standard] C-33 which gives the acceptable range of grain sizes retained by various sieve sizes for use as fine grained aggregate (ASTM, 1993); 13 grade requirements have been developed of coarse aggregate (ASTM, 1993, table 2). While some standards are established with possible national and international application, local ones can be devised as well. For example, Arizona Department of Transportation (1990) has a different size requirement for fine-grained aggregate than the one given by ASTM (table 3). One useful measure of material suitability for use is the plastic index (PI). It is the range of moisture content that gives a material plastic properties (Krynine and Judd, 1957) and is used to indicate the presence of undesirable minerals in alluvium. For example, ASTM D 3515 requires PI to be 4 or less for material used in asphalt concrete mixtures (White, 1991). Other important characteristics of surficial aggregate deposits include sufficient volume to justify extraction, proximity to market and transport, accessibility (spatially and legally), and minablity. 
Verde Valley study

Cox (1995) reported on the sand and gravel resources in the Verde Valley along the southwest edge of the CNF. Six tracts with geologic units known to contain sand and gravel deposits were developed using a number of recently published large scale maps of Quaternary geology including House and Pearthree (1993), Pearthree (1993), and House (1994). The quality of sand and gravel is qualitatively described for each tract as well as for the active channels of the Verde River. Cox (1995, map 1) identified sand- and gravel-bearing units as thin $(<40$ feet) or thick $(>40 \mathrm{ft}$ ); well or poorly sorted; with or without atypical clast-lithologies (for the area); and those with or without riparian vegetation. Cox (1995) found that the details were sufficient in the large scale maps used in the study to successfully distinguish among the various types of sand and gravel resources using depositional setting or geologic age. This level of mapping of Quaternary geology is not common in Arizona for areas away from major cities.

Soils

Wheeler and Williams (1974) reported the results of a soil survey in the Long Valley area (includes all of the Blue Ridge RD, Long Valley RD, and the southern half of Beaver Creek RD; see fig. 1). Three soil series were noted as possible sources of aggregate--the Arizo which was rated good for sand and fair to good for gravel (50 to 90 percent gravel), the Cowan series which was rated good for sand but unsuitable for gravel, and the Friana soil series which was rated fair for gravel (60-70 percent gravel) but unsuitable for sand. The Arizo soil series, likely with the best quality soil in terms of clast sizes in the Long Valley Area, is mapped as a part of the Cowan soil series. The Arizo and Cowan soil series were also rated good (A-1, A-2 respectively 2 ) as a source of road fill. The Arizo is classified as very gravely coarse sand and sand 3 with $15-55$ percent passing sieve No. 4 , 10-55 percent passing sieve no. 10, 5-15 percent passing sieve no. 40 , and 0-5 percent passing sieve no. 200; the Cowan is classified as a loamy fine sand, fine sand loam, and loamy sand with 100 percent passing sieve No. 4, 100 percent passing sieve no. 10, 50-75 percent passing sieve no. 40 , and $15-30$ percent passing sieve no. 200 (Wheeler and Williams, 1974, Table 9). Depth from surface is 0 to 60 inches; depth to bedrock is usually greater than 60 inches. The Friana soil series was rated good for fill (A-1) but only below a depth of 28 inches (Wheeler and Williams, 1974, Table 10).

The Arizo series develops on various types of materials in flood plain alluvium and is particularly prominent along the West Clear Creek and the Verde River. Soil surface tends to be irregular. Wheeler and Williams (1974) noted that the primary use of the soil is as a source of sand and

\footnotetext{
2 AASHTO rating system with seven classes (A-1 to A-7) where A-1 is assigned to soils with the highest bearing strength (i.e., best for subgrade) and A-7 is assigned to soils which are the worst with the lowest strength when wet (i.e., clayey soils ).

3 U.S. Department of Agriculture standard texture classification.
} 
gravel. Impurities include calcareous material throughout $(\mathrm{pH}$ of 8.4$)$ and organic material in the upper part (as thick as $30 \mathrm{~cm}$ (12 in.)) The typical C horizon (up to $1.4 \mathrm{~m}$ thick) may contain up to 80 percent cobbles of which many have calcareous coatings (Wheeler and Williams, 1974). The Cowan series (in the which the Arizo is found) develops on flood plains and low terraces containing sandstone and limestone adjacent to the Verde River and West Clear Creek. Impurities included calcareous material throughout ( $\mathrm{pH}$ of 8.4) and organic matter in the upper part (as thick as 51 cm (20 in.)) The two soil series are mapped together and these areas can have 1) one or the other soil, 2) soils adjacent to one another, and (3) one soil overlaying the other. The proportion of the two soils is highly variable and no estimate of percentages is provided by Wheeler and Williams (1974). Total area of the Cowan and Arzio soil series is 360 ha (890 acres). [Given an average thickness of $1.8 \mathrm{~m}(6 \mathrm{ft})$, the total volume of the two soils is on the order of 6.5 million $\mathrm{m}^{3}$.] Perhaps about half the area (i.e., the Arizo series only) is appropriate ( 3.3 million $\mathrm{m}^{3}$ ) if a source of both sand and gravel is sought. The overall thinness of the sand and gravel makes this soil less attractive. Thicker sections of sand and gravel within the soil might be sought.

The Friana series develops over very gravelly, cindery clay in old lake beds and depressions. These surfaces tend to be nearly level and are found as open parks and meadows in areas with basalts covered by pine trees. They develop from various types of material including volcanic ash, cinder, and basalt in horizons that are between 0.89 to $1.5 \mathrm{~m}$ ( 35 to $60 \mathrm{in}$.) thick. Gravel is found $0.70 \mathrm{~m}$ below the surface and to a depth of about $1.4 \mathrm{~m}$ which give an average gravel thickness of $0.7 \mathrm{~m}$ which in terms most sand and gravel deposits is too thin to be considered viable as a major supply. Total area of the Friana soil series is 460 ha (1140 acres). [Given an average thickness of $0.7 \mathrm{~m}(2.3 \mathrm{ft})$, the total volume of the two soils is on the order of 3.2 million $\mathrm{m}^{3}$.]

A number of other soils are described and located in the report by Wheeler and Williams (1974) as good for road fill but not as a source of sand and gravel. They include the Anthony (good, A-2), Overgaard (good to 10 inches, A-2), the Sanchez (good to poor, A-2 and A-6), and the Tortugas (good, unrated using AASHTO code).

Sources of impurities

Thin layers of bituminous-rank coal have been reported in the upper Paleozoic rocks of Fossil Creek Canyon in the Fossil Springs Wilderness. This area extends south into Tonto National Forest. Coal can be a deleterious mineral to surficial aggregate, particularly for fine aggregate used in fabrication of concrete roof tiles and may result in either leaky or cracked tiles. However, coal is not a usually a problem in other types of concrete or in road construction (Prentice, 1990). 
Alluvium characteristics inherited from bedrock sources

\section{Background}

Weathering and erosion of bedrock generates alluvium of varying quality. The summary that follows gives general characteristics of alluvium in basins developed along streams from various bedrock units as described by the Arizona Highway Department (1972) and Arizona Department of Transportation (1975). Geologic units are those used by Lane (1992) with some additions from Weir and others (1989) for age and lithology.

Pennsylvanian and Permian rocks are particularly complex and have been variously subdivided and grouped (Wier and others, 1989). As many basins and watersheds contain a mix of bedrock lithologies, the alluvium will have a mixture of qualities, some of which are noted below for various rock types:

Basaltic volcanic rocks.

Nearly all rocks of this type weather to form clays. Streams draining the extensive outcrops of these rocks in the CNF contribute to the large areas where suitable aggregate is absent.

Silicic volcanic rocks.

Weathering and erosion of silicic volcanic rocks can generate good quality sand and some gravelly sand but gravel-rich deposits are rare. Steam basins in the Peaks RD, particularly on the flanks of the San Francisco Peaks are most likely to have this type of aggregate.

Verde Formation.

This Tertiary unit is fine grained and not a source of alluvial aggregate.

\section{Moenkopi Formation}

Parts of the Moenkopi include: siltstone, claystone, sandstones and minor conglomerate near the base (Kiersch, 1955; Weir and others, 1989), and some parts have been used as a source of dimension stone. The lithologies it contains do not make it a promising source of alluvial aggregate with the possible exception of the basal conglomerates.

\section{Kaibab Formation}

The Kaibab consists of interbedded sandy limestone, sandstone, and chert, and weathering generates a very friable mixture of material.

\section{Toroweap Formation and Coconino Sandstone}

The lower Permian Toroweap Formation (which has been variously divided and also can include the Coconino Sandstone and is sometimes included with the upper part of the Supai Formation) is a sandstone, siltstone, mudstone, and conglomerate, with some minor dolomitic limestone. The Coconino Sandstone of lower Permian age (Weir and others, 1989) weathers and erodes like the other units noted here to generate sand and silt of a quality not suited for aggregate. PI values have been found between 7 and 20. 


\section{Supai Formation}

The Permian Supai Formation of thinly layered sandstone and lesser amounts of siltstones weathers and erodes to generate a silty sandy alluvium with friable fragments not suited for aggregate. PI values have been found between 7 and 20 . The unit crops out extensively particularly in the Sedona RD (fig. 1).

Redwall and Martin Limestone.

Streams developing on these Mississippian and Devonian age units can contain good-quality sand and gravel deposits free of contaminates. Unfortunately the units crop out in relatively small areas in the CNF.

Tonto Group (Tapeats Sandstone only).

The lower part of the Cambrian age Tapeats Sandstone is a sandstone, both massive and crossbedded, with coarse sand and pebble lenses. It may be arkosic (Weir and others, 1989). The upper part is soft calcareous siltstone and mudstones. Weathered rocks from the lower part are free of clays and have a low plastic index (PI, a desirable property). Inspection of the geologic map by Lane (1992, plate 2) shows the Tapeats with two relatively limited outcrops along the Verde River, south of Camp Verde, in the Beaver Creek RD (fig. 1).

\section{Precambrian Schist}

Schist tends to generate soft fissile material of poor quality for use as aggregate. An outcrop of schist is noted along the Verde River south of Camp Verde (Lane, 1992) in the Beaver Creek RD (fig. 1).

\section{Sources of crushed stone for construction and riprap}

\section{Introduction}

Following is a summary of general characteristics of various geologic units (Arizona Highway Department, 1972; Arizona Department of Transportation, 1975) within the CNF and their likely suitability as sources of crushed stone. Geologic units are those used by Lane (1992) with some additions of Weir and others (1989) for age and lithology. In general, most sandstone units found in Arizona do not meet abrasion requirements and are not usable in asphalitic concrete (Langland, 1987). As noted in the section on alluvium, Pennsylvanian and Permian rocks have particularly complex stratigraphy and have been variously subdivided and grouped.

\section{Basaltic volcanic rocks}

As noted previously, basalts are abundant in the CNF. They cover more than three quarters of the forest lands, and are found in two major fields: the San Francisco volcanic field in the Peak RD and Mormon Lake RD (fig. 1), and the Mormon Mountain volcanic field found in Mormon 
Lake, Blue Ridge, and Long Valley RDs, and eastern parts of Beaver Creek $\mathrm{RD}$. The Mormon Mountain volcanic field is slightly older and is dominated by Pliocene (?) and Miocene basaltic volcanic rocks in flow units from about 6-12 $\mathrm{m}$ thick. Lessor amounts of andesite are found in domes, flows and pyroclastic deposits (Weir and others, 1989). Tertiary and Quaternary basalts are found in the San Francisco volcanic field which was active during the Pliocene and Pleistocene (Newhall and others, 1987). Compositionally the field is dominated by basalt and basaltic andesite with lesser amounts of andesite, benmoreite, and dacite. Basalts and related lithologies have been mapped and studied in numerous studies in and adjacent to the CNF, some of which are identified in the introduction.

A somewhat expanded discussion on basalt is included here because they are so prevalent in the CNF, and likely a continued important source of aggregate. Basalts found in the CNF have been used by ADOT in asphalt mix for road surfaces (Lane, 1992). A number of sites used as a source of aggregate and other construction material by $\mathrm{ADOT}$ are described in a material inventory of Coconino and Yavapai Counties (Arizona Department of Transportation, 1975; 1972). See figure 2 for the areas of each county within the CNF.

While basalts can be an excellent source of good quality aggregate as well as fair to excellent riprap (Kiersch, 1955), weathering produces clays, including montmorillonite, that can occur in seams which may not be apparent until quarrying is underway. Intrusive basaltic rocks are less uniform in composition and geotechnical properties and often crop out in ways that make them difficult to mine. As a general rule, younger basaltic volcanic rocks are better than older ones. Therefore, basalts found in the younger San Francisco volcanic field are likely to make better aggregate than those found in the older Mormon Mountain volcanic field.

Basalt and diabase (gabbro or basalt composition) are identified by stone producers as "trap" rocks when intrusive (Dunn, 1991). Composition and mineralogy of these rocks effect their use as aggregate. Glasses are frequently present in extrusive rocks, particularly those with more silica. These rocks then are highly reactive with the alkali in Portland cement. Basaltic and related rock types also can be mechanically weakened by the presence of the round grains of olivine, particularly if abundant. Olivine's rounded crystal form does not interlock well with other minerals or the matrix (Dunn (1991). Quartz (albeit a mineral not commonly found in basalt) is an example of a mineral which tightly interlocks with other crystals (Dunn, 1991; Herrick, 1994). Brattli (1992) found that mechanical strength also decreased as the amphibole to pyroxene ratio increased. Dunn (1991) suggest that amphiboles (actinolite, tremolite, anthophyllite) have more brittle crystals and this may account for some of the decrease in strength as reported by Brattli (1992).

Ferromagnesian minerals in basalts and related rock-types weather rapidly under humid climates, producing swelling clays (e.g., smectite) which destroy the mechanical integrity of the rock (Prentice, 1990). Surface weathering reduces both impact strength and abrasion strength (Haraldsson, 1984). Like weathering, hydrothermal alteration of igneous and other rock types can make them unsuitable for use as aggregate 
(Dunn, 1991). Additional mechanically weakness may be due to deuteric alteration of the olivines (by late stage fluids associated with the magma) where the minerals formed may include clay and hydrous iron minerals (iddingsite) (B.B. Houser, written commun., 1997).

Brattli's (1992) study of basaltic igneous rocks suggests that strength increases as the mean grain size decreases and is particularly strong for mean grain sizes under $1 \mathrm{~mm}$. This and possibly other geologic properties may be promising in predicting the mechanical properties (e.g., impact value, flakiness value, abrasion value, etc.) of basaltic rocks given absence of direct measurements.

Presence of cracks and flaws (e.g., holes) affect mechanical strength and are found both along grain boundaries and within the minerals. Most cracks have lengths "usually $1 / 10$ the grain size" (Brattli, 1992, p. 37). Some dense gabbros and diabases can be nearly crack-free (Spunt and Brace, 1974). Rocks with smaller grains can also be expected to have shorter cracks which contributes to better mechanical strength.

The discussion to this point clearly shows that basalt and related rock types have both good and bad features when used as aggregate. Prentice (1990, fig. 3.5b) showed that most basalt can have the same low aggregate abrasion values (results of a UK test somewhat analogous to the Los Angeles abrasion test) as seen for granite. A preliminary model of the Los Angeles abrasion (wear) test (LAWT) results showed low aggregate abrasion values for Quaternary and Tertiary basaltic rocks (fig. 4) from 13 sites in Coconino and Yavapai Counties in and adjacent to the CNF plus 6 sites in basalts from New Mexico. All the sites have LAWT values less than 40 percent loss which is a common maximum in standards for material used as aggregate. These results, as a group, have a distribution of values which can be described using the normal distribution as a preliminary model (fig. 4). The test used to compare sample distributions of Los Angeles abrasion (wear) test values to normal distributions was Lilliefors' test, a special form of the Kolmogorov-Smironov test (Rock, 1988). Some values in models which follow are transformed into logarithms when the histograms for engineering characteristics were skewed. In the Lilliefors' test, the Kolmogorov-Smironov test statistic, $\mathrm{d}_{\max }$, is compared to a table of critical values based on the mean and standard deviation from the sample data, not the parent population. The normal or lognormal distribution were rejected as being inappropriate to describe the sample distribution at the 5-percent confidence level.

Herrick (1994) reports that the average LAWT for basalt commonly used for crushed stone is 14 percent and a little lower than the mean value of 21 percent in the preliminary model (fig. 4). On the other hand, unconsolidated cinders, clinkers and other unconsolidated basaltic materials are less suitable in terms of LAWT results with slightly less than half the sites exceeding the 40 percent maximum loss usually allowed for use as aggregate (fig. 5). These results, as a group, have a distribution of values which can be described using the normal distribution as a preliminary model (fig. 5). While cinders, clinker and other unconsolidated basaltic material are easier to mine, their quality is poor 
and their low durability will make roads on which they are used subject to more frequent maintenance.

Data on basalts for sites beyond the study area as reported by others tend to have higher variability in aggregate abrasion values; about 15 percent of the samples have values greater (that is, of poor quality) than observed in granites (Prentice, 1990; fig. 3.5b). On the other hand, another UK test, the aggregate crushing test (percent fines produced when standard pressure applied to sample for 10 minutes) shows basalt to be clearly better (less fines) than granite, at least in the context of the test (Prentice, 1990; fig. 3.2b).

\section{Silicic volcanic rocks}

Rhyolites are much less abundant than basalts in the CNF. The closest lithology to rhyolites in the Mormon Mountain volcanic field is a rhyodacite dome on the south side of Mormon Mountain and a small dome south of Mormon Lake, both in the Mormon Lake RD (see Weir and others, 1989). Rhyolites are more common in the San Francisco volcanic field (Wolfe, Ulrich, Holm, and others (1987), particularly around the major eruptive centers both in or adjacent to the Peaks RD. Most outcrops are for domes although a few rhyolite flows are noted. An example of rhyolite domes outside of major eruptive centers is an outcrop six miles southwest of Flagstaff at vent 0614 (see sheet 1, Wolfe, Ulrich, Holm, and others (1987).

Three major eruptive centers in the San Francisco volcanic field and in the CNF are Kendrick Peak, O'Leary Peak and the extensive San Francisco Mountain complex. The Kendrick Peak center, in northwest Peaks RD, is partly in the CNF and partly in the Kaibab NF. Seven or eight rhyolite domes are recognized. A rhyolite dome is recognized at Robinson Crater, part of the O'Leary Peak eruptive center, northeast of San Francisco Mountain (Moore and Wolf, 1987). The San Francisco Mountain eruptive complex, north of Flagstaff, includes several rhyolite domes and a few flows of various sizes include ones seen at Core Ridge, Doyle Spring, Hochderffer Hills, Raspberry Springs, Sugarloaf Dome, and White Horse Hills ( Wolfe, Ulrich, Holm, and others, 1987).

Rhyolites and related extrusive rocks can make good quality aggregate. As a rule of thumb, coarse-grained igneous rocks tend to have weaker interlocking grains than ones with fine to medium grain sizes. However, they are silica rich and are more likely to contain glass, which is highly reactive with the alkali in Portland cement (Dunn, 1991). Flowbanding may result in undesirable elongated fragments in crushing (Smith and Collis, 1993). Jointing is common and can make outcrops easier to work but may also generate oversized blocks requiring boulder blasting. Platy jointing can occur in smaller intrusive bodies and result in undesirable slabs during crushing.

A preliminary model of LAWT results is developed for rhyolites found in New Mexico (fig. 6) and may be applicable to similar, but less abundant, lithologies in the CNF. The rhyolitic model is problematic in that the highest value (39 percent loss) and lowest value (11.2 percent loss) were excluded from the data set. The distribution used to describe the 
remaining data is logarithmic (log base 10) as the data are skewed. A variety of intermediate to silica-rich lithologies is included and

improvement in the preliminary model is likely (and needed) given more data. In terms of LAWT results, this group of sites is very comparable to those given for basalts (fig. 4). Herrick (1994) reports that the average LAWT for felsite (includes andesite, dacite, rhyolite and trachyte) commonly used for crushed stone is 18 percent and comparable to the geometric mean of the preliminary model of 20 percent (fig. 6).

Verde Formation

Most of the unit is not sufficiently consolidated to be crushed; some of the limestone lenses may be crushable but would supply only a limited amount of materials.

Chinle Formation

The unit varies from siltstones and sandstones in the lower part, has increasing claystone in the middle, and alternating beds of siliceous limestones and siltstones near the top (Kiersch, 1955). The limestone stringers and lens are likely sources of aggregate of varying quality (Kiersch, 1955).

Moenkopi Formation

This includes an assemblage of siltstone, claystone, sandstone and minor conglomerate occurring near base (Kiersch, 1955; Weir and others, 1989). While used as source of dimension stone, its suitability for quality aggregate is not known. Some of the blocky sandstones in this formation are a fair quality riprap (Kiersch, 1955).

Toroweap Formation and Coconino Sandstone

The Toroweap Formation is predominantly a cross-bedded quartzose sandstone (Weir and others, 1989). No report on its use as aggregate or riprap was found.

The crushing strength of limestone in the Coconino is reported in Kiersch (1955) to be between 4,500 and 9,400 pounds per square inch (PSI) (320 and 1,200 kilograms per square centimeter $\left(\mathrm{kg} / \mathrm{cm}^{2}\right)$ ) based on tests of 4 fine-grained, freshly quarried blocks. The average crushing strength is about 6,700 PSI $\left(470 \mathrm{~kg} / \mathrm{cm}^{2}\right)$. These samples were collected in the NavajoHopi Indian Reservations and may not be representative of limestone in the Coconino Sandstone in the CNF.

Kaibab Formation

Langland (1987) noted that the Kaibab Formation has been considered a suitable source of limestone because it contains 70 percent or more calcium and magnesium carbonates. However, like other limestones, it 
may be undesirable as a surfacing material due to poor frictional properties (Langland, 1987). Polishing of coarse aggregate in the wear surface of roadways is commonly due to uniform wearing of the aggregate microtextures, particularly those which are fine grain, like limestones. Use of limestone in the wear surface is usually considered suitable if the insolubles are 10 percent or greater (White, 1991). Kiersch (1955) reports that blocky limestone beds in this unit have provided good quality riprap.

A LAWT preliminary model of material taken from quarries and pits in the Kaibab Formation (fig. 7) in northern Arizona suggests that about a fourth of the sites have test results which are too large--exceeding the 40 percent loss limit--usually required for use in aggregate. The distribution used to describe the data is logarithmic (log base 10) as the data are skewed. Herrick (1994) reports that the average LAWT for limestone found elsewhere, outside this study, and commonly used for crushed stone is 26 percent which is lower than the geometric mean of 31 percent in the preliminary model (fig. 7).

Supai Formation.

The Permian Supai Formation consists of thinly layered sandstone and lesser amounts of siltstones. Elsewhere in the Colorado Plateau, limestone lenses have been located and used as fair quality, although small size, riprap (Kiersch, 1955). The unit crops out extensively, particularly in the Sedona RD (fig. 1).

\section{Redwall Limestone}

This Mississippian-aged unit commonly crops out as cliffs consisting of massive limestone, about half of which consists of dolomite. Chert and shale beds are also present and degrade the value of crushed stone produced if included. Mineability may be an issue, considering the nature of outcrops.

Three areas need to be checked as a location for possible production of crushed limestone within the Coconino NF as discussed previously.

\section{Martin Limestone}

This Devonian-aged unit consists mostly of dolomite that may be suitable as a crushed stone aggregate if not too reactive; particularly if the thin shale beds are avoided.

\section{Tonto Group (Tapeats Sandstone only)}

The lower part of the Cambrian age Tapeats Sandstone is both massive and crossbedded, with coarse sand and pebble lens but its suitability for crushing in unknown. 
Precambrian schist

Most schist is fissile and not suitable for crushing.

\section{Metals}

\section{Introduction}

The CNF is notable for the absence of metallic deposits within its boundaries, but a number of formations which are in the CNF do host metallic deposits elsewhere. The three metallic deposit types discussed here lack deposit models: (1) strata-bound manganese, (2) replacement iron deposits, and (3) the base-metal-enriched remnant deposits of solutioncollapse breccia pipe uranium deposits. Sediment-hosted $\mathrm{Cu}$ deposits, redbed type, are recognized as permissible in the CNF based on tracts found in the mineral-resource assessment for undiscovered resources of gold, silver, copper, lead, and zinc in the conterminous United States conducted by the USGS from 1993 through 1995 (Ludington and Cox, 1996)).

\section{Strata-bound manganese}

Four manganese occurrences have been described in the CNF in the Long Valley district. The Long Valley Ranger and Blue Ridge RDs (fig. 1), are described in MRDS Nos. 2 (Dennison Group), and 5 (Shoup Group). Other nearby occurrences are described in MRDS Nos. 3 (Lost Apache claim) and 4 (Blue Ridge property) (fig. 2). Welty and others (1989) classified the Long Valley mineralization as strata-bound and (or) stratiform. Farnham and Stewart (1958) classified these occurrences as replacement and residual deposits. The Coconino Sandstone at Long Valley has manganese in thin beds and nodular masses, some of which are as large as 100 tons (Dorn, 1969). Farnham and others (1961) described manganese mineral in soil and gravel, which may be detrital.

Dorn (1969) also suggested that some manganese may be precipitated as manganese oxides from groundwater. Cox (1991) suggested that similar-type deposits in northwest Virginia were also transported by ground water. The Coconino Sandstone may provide a geochemical trap like those for residual manganese deposits described by Force (1991) for similar-type deposits in some lower Paleozoic rocks of Virginia. Lane (1992) describes the CNF sites as containing nodules of too little material to be viable as a resource.

Grade and tonnage models for these manganese deposit types are not available. The permissive tracts for these manganese deposit types are outcrops of Coconino Sandstone which hosts the known deposits. 


\section{Replacement iron deposits}

Iron has been mined from a deposit in the Redwall Limestone for use as mineral pigment (Klemic, 1969). The Seligman iron district (MRDS Record No. M003329, not shown on fig. 2), 19 miles south of Seligman, Ariz., was classified by Welty and others (1989) as stratiform. Harrer (1964) described the deposit as a replacement along the contact between the limestone and an andesite porphyry sill. The deposits was worked for hematite (with grades between 55 and 68 percent $\mathrm{Fe}$ ). This is the only known deposit of this type hosted by the Redwall Limestone in Arizona. Other replacement iron deposits in the western United States are usually found in "volcanic rocks, brecciated igneous rocks, and limestone" (Klemic and others, 1973; p 301). Most iron replacement deposits consist of siderite which can be weathered to hematite (Laznicka, 1985).

A grade and tonnage model for replacement iron deposits is not available. Laznicka (1985) suggests, world-wide, that past production plus known reserves from iron replacement deposits in carbonates are on the order of 130 million $t$. A model could be attempted, given data on a sufficient number of deposits, but the discussion in Laznicka (1985) also suggests that classification of these iron deposit types will be a problem.

Permissive tracts are the outcrop of the Redwall Limestone. The presence of an intrusive like that at Seligman would be necessary but may not be seen in outcrop. If other limestone-bearing formations are also permissive, outcrops of Kaibab Formation are also possibly permissive for replacement iron deposits as well. The likelihood of intrusives (including sills) is high in most parts of CNF with the possible exception of the Beaver Creek RD.

\section{Remnants of solution-collapse breccia pipe uranium deposits}

The assessment of solution-collapse breccia pipe uranium deposits is found in Bliss and Pierson (1994). However, when these deposits become exposed at the surface, they are depleted in uranium and enriched in copper by supergene processes (Finch and others, 1992). In effect, solutioncollapse breccia pipe uranium deposits become copper deposits if weathering is extensive; otherwise a copper-enriched zone is present on a solution-collapse breccia pipe uranium deposit. Supergene mineralization, either partial or relatively complete, will be called remnant deposits in this discussion. In effect, the model by Finch and others (1992) is not applicable.

Currently recognized remnant deposits like Grandview and Copper Mountain are all from the Colorado Plateau and are, on average, two orders of magnitude smaller $(\sim 1,000 \mathrm{t})$ than solution-collapse breccia pipe uranium deposits, which have a median size of 230,000 $t$ (Finch and others, 1992, fig. 21). The largest remnant deposit is $11,000 \mathrm{t}$. Remnant deposits historically have been worked primarily for copper; grades are usually between 3.2 and 33 percent; the median grade is 10 percent copper. Other base metals produced as by-products include lead in about half the deposits 
and zinc in about a third. Lead grades are less than 0.6 percent and zinc grades are less than 0.8 percent. Silver is produced in nearly all the deposits with grades between 9 and $270 \mathrm{~g} / \mathrm{t}$; the median grade is $50 \mathrm{~g} / \mathrm{t}$. Gold is produced in about a third; the grades are quite low--usually less than 250 ppb. Remnant deposits are not reported as producing uranium.

All exposures of the Coconino Sandstone are permissive for these deposits. Forested areas or those covered by thin volcanic sequences are likely areas containing undiscovered deposits of this type.

\section{Sediment-hosted Cu deposits, redbed type}

In a mineral-resource assessment for undiscovered resources of gold, silver, copper, lead, and zinc in the conterminous United States (Ludington and Cox, 1996), small portions of two tracts found in the CNF are permissible for sediment-hosted $\mathrm{Cu}$ deposits, red-bed type. Tract CP01 was delineated using the presence of permeable sandstones in "the lower part of the Upper Triassic Chinle Formation (including the Shinarump and Agua Zarca Sandstone Member)" (Lindsey, 1996a, p. 72). The White Canyon deposit, Utah $(530,000 \mathrm{t}$ at 0.75 percent $\mathrm{Cu})$ is an example of the sediment-hosted $\mathrm{Cu}$ deposits, red-bed type on the Colorado Plateau. The world red-bed model (Mosier and others, 1986) can be used to characterize the size and grade distributions of undiscovered deposits (Lindsey, 1996a). The total tract area is $36,300 \mathrm{~km}^{2}$ including outcrops in Arizona, Colorado, New Mexico and Utah. The estimated number of undiscovered deposits for the full tract are at the following percentiles: 90th--0, 50th--0, 10th--1, 5th--2, and 1st--4.

Tract CP02 of the conterminous United States assessment was delineated using the presence of permeable sandstones in "Hermosa Group and Cutler Formation in Utah, and the Naco Formation in Arizona" (Lindsey, 1996b, p. 73). Examples of known sediment-hosted red-bed type $\mathrm{Cu}$ deposits in this tract are all smaller than the median red-bed tonnage of the world red-bed model (Mosier and others, 1986). Therefore, undiscovered deposits consistent with the size and grade distributions of the model are much more unlikely (Lindsey, 1996b). The total tract area is $17,800 \mathrm{~km}^{2}$ including outcrops in Arizona, New Mexico and Utah and estimates of undiscovered deposits were made at the following percentiles: 90th--0, 50th-0,10 th--0, 5th--1, and 1st--3.

The low probabilities associated with the estimated numbers of undiscovered deposits of sediment-hosted $\mathrm{Cu}$ deposits, red-bed type, in the two tracts in the Colorado Plateau (Lindsey, 1996a, b) suggests the chance of undiscovered deposits of this deposit type are remote for the full tracts and will be even less for portions thereof within the CNF. The chance of an undiscovered deposit is slightly higher in areas of tract CP01 than for tract CP02 which may be a consideration in property exchange. 


\section{Other metallic deposit types}

Tracts for porphyry copper deposits are also found in the resource assessment for undiscovered resources of gold, silver, copper, lead, and zinc in the conterminous United States (Ludington and Cox, 1996). One of the tracts in Arizona-- SB10--is mostly southwest of the CNF (Cox, 1994, 1996). Parts of the tract are defined by using a $10 \mathrm{~km}$ buffer zone around Laramide intrusives. Several intrusives suspected to be Laramide in age are found in the southern Black Hills (Luedke and Smith, 1978) about $15 \mathrm{~km}$ south of Camp Verde (fig. 1). Luedke and Smith (1978) described the intrusive rocks as being of uncertain assemblage and characteristics. The buffer zone around these intrusives includes rocks in the basement of the southeast end of the Verde Basin and in the CNF southeast of Camp Verde. The area covered with Verde Formation and younger sediments is permissible for an undiscovered porphyry copper deposit.

A number of other deposits types are associated with felsic intrusions into carbonates as well as into other rock types (Cox and others, 1986, table 1) which may be part of the unexposed or poorly exposed assemblage of rocks associated with volcanic centers in the CNF. This includes the baseand precious-metal skarns, veins, and replacement deposits of various types. Evidence of mineralization with a felsic intrusive are seen in workings, including a shaft at least 15 feet $(4.6 \mathrm{~m})$ deep and pits at Slate Mountain (Lockrem, 1983) located in the northwest corner of the Peaks RD (located approximately as "SL" on fig. 2). The workings are located in a contact metamorphic zone where rhyolite intrudes into the Martin Formation perhaps showing evidence for skarn-type mineralization. The zone is characterized by bleaching, brecciation, and magnetite and hematite mineralization occurring in concordant and discordant veins (Lockrem, 1983). Trace amounts of copper (300-3000 ppm), lead (1000-3000 $\mathrm{ppm})$, and zinc (60-1200 ppm) were detected in four particularly wellmineralized samples (Lockrem, 1983). The description is too incomplete to classify the prospect by deposit type but the presence of the site is encouraging evidence that undiscovered deposits of types associated with felsic intrusions into carbonates may exist in the CNF. 


\section{References Cited}

Appleyard, F.C., 1983, Gypsum and anhydite, in Lefond, S.J., ed., Industrial minerals and rocks: New York, Society of Mining Engineers, v. 2, p. 775792.

Arizona Bureau of Mines [Arizona Geological Survey], 1958, Geologic map of Yavapai county, Arizona: Tucson, Arizona Bureau of Mines [Arizona Geological Survey], and University of Arizona, scale 1:375,000.

Arizona Department of Transportation, 1975, A materials inventory of Coconino County: Arizona Department of Transportation, Highway Division and Federal Highway Administration, 123 p.

Arizona Department of Transportation, 1990, Standard specifications for road and bridge construction: Arizona Department of Transportation, Highway Division, $800 \mathrm{p}$.

Arizona Highway Department, 1972, A materials inventory of Yavapai County: Arizona Highway Deparment and Federal Highway Administration, 65 p.

ASTM, 1993, Annual book of ASTM standards: American Society for Testing and Materials (ASTM), Section 4 construction, v. 04.02, p. 10-15.

Bliss, J. D., 1993, Mineral resource assesment of undiscovered mineral deposits for selected mineral deposit types in the Kaibab National Forest, Arizona, with a section on Mineral resource assessment of solutioncollapse breccia pipe uranium deposits by J. D. Bliss and Charles T. Pierson: U.S. Geological Survey Open-File Report 93-329, 67 p.

Bliss, J.D., and Pierson, C.T., 1994, Mineral resource assessment of undiscovered solution-collapse breccia pipe uranium deposits in the Coconino National Forest, Arizona: U.S. Geological Survey Open-File Report 94-566, 16 p.

Bliss, J.D., ed., 1992, Developments in mineral deposits modeling: U.S. Geological Survey Bulletin 2004, 168 p.

Bolen, W.P., 1994, Pumice and pumicite, in Mineral commodity summareies in 1993: U.S. Bureau of Mines, p. 1-5.

Brattli, Bjørge, 1992, The influence of geological factors on the mechanical properties of basic igneous rocks used as road surface aggregates: Engineering Geology, v. 33, no. 1, p. 31-44.

Burchard, E.F., 1914, Stone, in Mineral resources of the United States, 1913: U.S. Geological Survey, pt. 2, p. 1285-1410. 
Chaffee, M.A., King, H.D., Briggs, P.H., Fey, D.L., Knight, R.J., Motooka, J.M., and Roushey, B.H., 1996a, Analytical results for rock and streamsediment samples, Coconino National Forest, Coconino, Gila, and Yavapai Counties, Arzona: U.S. Geological Survey Open-File Report 96282-A, $160 \mathrm{p}$.

Chaffee, M.A., King, H.D., Briggs, P.H., Fey, D.L., Knight, R.J., Motooka, J.M., and Roushey, B.H., 1996b, Analytical results for rock and streamsediment samples, Coconino National Forest, Coconino, Gila, and Yavapai Counties, Arzona: U.S. Geological Survey Open-File Report 96282-B, Diskette.

Cox, D.P., 1986, Descriptive model of sediment-hosted Cu, in Cox, D.P., and Singer, D.A., eds., 1986, Mineral deposit models: U.S. Geological Survey Bulletin 1693, p. 205.

Cox, D.P., and Singer, D.A., eds., 1986, Mineral deposit models: U.S. Geological Survey Bulletin 1693, 239 p.

Cox, D.P., Barton, P.B., and Singer, D.A., 1986, Introduction, in Cox, D.P., and Singer, D.A., eds., 1986, Mineral deposit models: U.S. Geological Survey Bulletin 1693, p. 1-10.

Cox, L.J., 1991, Manganese contents of some lower Paleozoic carbonate rocks of Virginia, in Manganese contents of some sedimentary rocks of Paleozoic age in Virginia: U.S. Geological Survey Bulletin 1916, p. B1-B16.

Cox, L.J., 1994, Porphyry copper deposits in Arizona--an example of resource evaluation fo rthe U.S. Geological Survey's National Mineral Assessment of copper, lead, zinc, gold, and silver, in Carter, L.M.H., Toth, M.I., and Day, W.C., eds.,USGS research on mineral resources--1994, part A-program and abstract: U.S. Geological Survey Circular 1103-A, p. 19-21.

Cox, L.J., 1995, An evaluation of sand and gravel resources in and near the Verde Valley of the Coconino National Forest, Arizona: U.S. Geological Survey Open-File Report 95-31, 1 sheet, scale 1:126,720, 20p.

Cox, L.J., 1996, SB10--porphyry Cu deposits, Arizona, in Ludington, Steve, and Cox, D.P., eds., Data base for a National mineral resource assessment of undiscovered deposits of gold, silver, copper, lead, and zinc in the conterminous United States: U.S. Geological Survey Open-File Report 9696, CD ROM, p. 491-493.

Dorn, J.V.N.,II, 1969, Manganese, in U.S. Geological Survey, Arizona Bureau of Mines, and U.S. Bureau of Reclamation, Mineral and water resources of Arizona: United States, Senate, 90th Congress, 2d Session, p. 211-225.

Drake, Bob, 1995, Comment--finding answers to the fines problem: Rock Products, v. 98, no. 9, p. 25. 
Dunn, J.R., 1991, Geology and exploration, in Barksdale, R.D., ed., The aggregate handbook: Washington, D.C., National Stone Association, p. 4-1 to $4-45$.

Farnham, L.L., and Stewart, L.A., 1958, Manganese deposits of western Arizona: U.S. Bureau of Mines Information Circular 7843, 87 p.

Farnham, L.L., Stewart, L.A., and Delong, C.W., 1961, Manganese deposits of eastern Arizona: U.S. Bureau of Mines Information Circular 7990, 178 p.

Finch, W.I., Pierson, C.T., and Sutphin, H.B., 1992, grade and tonnage model of solution-collapse breccia pipe uranium deposits, in Bliss, J.D., ed., Developments in mineral deposit modeling: U.S. Geological Survey Bulletin 2004, p. 36-38.

Finch, W.I., Sutphin, H.B., Pierson, C.T., McCammon, R.B., and Wenrich, K.J., 1990, The 1987 estimate of undiscovered uranium endowment in solution-collapse breccia pipes in the Grand Canyon Region of northern Arizona and adjacent Utah: U.S. Geological Survey Circular 1051, 19 p.

Force, E.R., 1991, Manganese contents of some lower Paleozoic carbonate rocks of Virginia, in Manganese contents of some sedimentary rocks of Paleozoic age in Virginia: U.S. Geological Survey Bulletin 1916, p. A1-A9.

Funnell, J.E., and Wolfe, E.J., 1964, Compendium on nonmetallic minerals of Arizona: San Antonio, Texas, Southwest Research Institute Report, 335 p. [prepared for the Arizona Public Service Company, Phoenix, Arizona]

Geitgey, R.P., 1994, Pumice and volcanic cinder, in Carr, D.D., and others, eds., Industrial minerals and rocks: Littleton, Colo., Society for Mining Metallurgy, and Exploration, p. 803-813.

Goldman, H.B., 1994, Sand and Gravel, in Carr, D.D., ed., Industrial minerals and rocks (6th ed.): Littleton, Colo., Society for Mining, Metallurgy, and Exploration, Inc., p. 869-877.

Gunther, T.M., 1992, Quantitative assessment of future development of copper/silver resources in the Kootenai National Forest, Idaho/Montana: part II--ecomonic and policy analysis: Nonrenewable Resources, v. 1, no. 4 , p. 267-280.

Haraldsson, H., 1984, Relation between petrology and the aggregate properties of Iclandic rocks: Bulletin of the International Association of Engineering Geologists, v. 30, p. 73-76.

Harben, P.W., and Bates, R.L., 1984, Geology of the nonmetallics: New York, Metal Bulletin Inc., 392 p. 
Harben, P.W., and Bates, R.L., 1990, Industrial minerals geology and world deposits: New York, Metal Bulletin Inc., 312 p.

Harrer, C.M., 1964, Reconnaissance of iron resources in Arizona: U.S. Bureau of Mines Information Circular IC 8236, $204 \mathrm{p}$.

Harris, D.P., 1984, Mineral resource appraisal--mineral endowment, resources, and potential supply; concepts, methods, and cases. Oxford, Clarendon Press, 445 p.

Herrick, D.H., 1994, Stone, crushed, in Carr, D.D., ed., Industrial minerals and rocks (6th ed.): Littleton, Colo., Society for Mining, Metallurgy, and Exploration, Inc., p. 975-986.

Hoffer, J.M., 1991, Pumice and pumicite in Arizona: Arizona Department of Mines and Mineral Resources Open File Report 91-8, 67 p.

Hoffer, J.M., 1994, Pumice and pumicite in New Mexico: New Mexico Bureau of Mines and Mineral Resources Bulletin 140, 23 p.

Hopkins, R.L., 1990, Kaibab Formation, in Beus, S.S., and Morales, Michael, ed., Grand Canyon geology: New York, Oxford University Press, p. 225245.

House, P.K, 1994, Surficial geology of the southern Verde Valley, Yavapai County, Arizona: Arizona Geological Survey Open-File Report 94-23, 20 p. 3 map sheets, scale 1: 24,000 .

House, P.K, and Pearthree, P.A., 1993, Surficial geology of the nortthern Verde Valley, Yavapai County, Arizona: Arizona Geological Survey Open-File Report 93-16, 19 p. 4 map sheets, scale 1: 24,000.

Houser, B.B., 1992, Map of industrial mineral occurrences in the National Forests of Arizona: U.S. Geological Survey Open-File Report 92-687, scale 1:500,000, 1 sheet, $30 \mathrm{p}$.

Huhta, R.S., 1991. Introduction to the aggregate industry, in Barksdale, R.D. ed, The aggregate handbook: Washington, D.C., National Stone Association, p. 1-1 to 1-14.

Keith, S.B., 1969a, Basalt and related rocks, in U.S. Geological Survey, Arizona Bureau of Mines, and U.S. Bureau of Reclamation, Mineral and water resources of Arizona: United States, Senate, 90th Congress, 2d Session, p. 315-320.

Keith, S.B., 1969b, Gypsum and anhydrite, in U.S. Geological Survey, Arizona Bureau of Mines, and U.S. Bureau of Reclamation, Mineral and water resources of Arizona: United States, Senate, 90th Congress, 2d Session, p. 371-382. 
Keith, S.B., 1969c, Limestone, dolomite, and marble, in U.S. Geological Survey, Arizona Bureau of Mines, and U.S. Bureau of Reclamation, Mineral and water resources of Arizona: United States, Senate, 90th Congress, 2d Session, p. 385-398.

Keith, S.B., 1969d, Pumice and Pumicite, in U.S. Geological Survey, Arizona Bureau of Mines, and U.S. Bureau of Reclamation, Mineral and water resources of Arizona: United States, Senate, 90th Congress, 2d Session, p. $407-412$.

Keith, S.B., 1969e, Sandstone, in U.S. Geological Survey, Arizona Bureau of Mines, and U.S. Bureau of Reclamation, Mineral and water resources of Arizona: United States, Senate, 90th Congress, 2d Session, p. 441-448.

Kiersch, G.A., 1955, Construction materials: Tucson, University of Arizona Press, v. III, 81 p.

Klemic, Harry, 1969, Iron, in U.S. Geological Survey, Arizona Bureau of Mines, and U.S. Bureau of Reclamation, Mineral and water resources of Arizona: United States, Senate, 90th Congress, 2d Session, p. 168-182.

Klemic, Harry, James, H.L., and Eberlein, G.D., 1973, Iron, in Brobst, D.A., and Pratt, W.P., eds., United States Mineral Resources: U.S. Geological Survey Professional Paper 820, p. 291-306.

Krynine, D.P., and Judd, W.R., 1957, Principles of engineering geology and geotechnics: New York, McGray-Hill Book Co., 730 p.

Lane, M.E., 1992, Mineral appraisal of the Coconino National Forest, Arizona: U.S. Bureau of Mines Mineral Land Assessment Open File Report MLA 11-92, scale 1:126,720, 3 sheets, $93 \mathrm{p}$.

Langer, W. H.,, 1988, Natural aggregate of the Conterminous United States: U.S. Geological Survey Bulletin 1594, 33 p.

Langland, Leo, 1987, Locating, sampling, and evaluating potential aggregate deposits, in Peirce, H.W., ed., 21st forum on the geology of industrial minerals: Arizona Bureau of Geology and Mineral Technology Special Paper 4, p. 116-119.

Laznicka, Peter, 1985, Emperical metallogeny--depositional environment, lithologic associations, and metallic ores: New York, Elsevier, v. 1, Phanerozic environments, associations and deposits, pt. B, p. 1290.

Lefond, S.J., ed., 1983, Industrial minerals and rocks: New York, American Institute of Mining, Metallurgical, and Petroleum Engineers, Inc., v. 1, 722 p. 
Lindsey, D.A., 1996a, CP01--sediment-hosted Cu deposits, red bed type, Utah, Arizona, Colorado, New Mexico, in Ludington, Steve, and Cox, D.P., eds., Data base for a National mineral resource assessment of undiscovered deposits of gold, silver, copper, lead, and zinc in the conterminous United States: U.S. Geological Survey Open-File Report 96-96, CD ROM, p. 72.

Lindsey, D.A., 1996b, CP02--sediment-hosted Cu deposits, red bed type, Utah, Arziona, New Mexico, in Ludington, Steve, and Cox, D.P., eds., Data base for a National mineral resource assessment of undiscovered deposits of gold, silver, copper, lead, and zinc in the conterminous United States:

U.S. Geological Survey Open-File Report 96-96, CD ROM, p. 73.

Lockrem, T.M., 1983, Geology and emplacement of the Slate Mountain volcanolaccolith, Coconino County, Arizona: Flagstaff, Northern Arizona University Masters thesis, $103 \mathrm{p}$.

Ludington, Steve, and Cox, D.P., eds., 1996, Data base for a National mineral resource assessment of undiscovered deposits of gold, silver, copper, lead, and zinc in the conterminous United States: U.S. GeologicalSurvey OpenFile Report 96-96, CD ROM.

Luedke, R.G., and Smith, R.L., 1978, Map showing distribution, composition, and age of late Cenozoic volcanic centers in Arizona and New Mexico: U.S. Geological Survey Miscellaneous Investigations Series Map I-1091-A, scale $1: 1,000,000$.

Marek, C.R., 1991, Basic properties of aggregate, in Barksdale, R.D., ed., The aggregate handbook: Washington, D.C., National Stone Association, p. 3-1 to $3-81$.

Mason, B.H., 1994, Lightweight aggregate, in Carr, D.D., and others, eds., Industrial minerals and rocks: Littleton, Colo., Society for Mining Metallurgy, and Exploration, p. 343-350.

Moore, R.B., and Wolfe, E.W., 1987, Geologic map of the east part of the San Francisco volcanic field, north-central Arizona: U.S. Geological Survey Miscellaneous Field Studies Map MF-1960, scale 1:50,000, 2 sheets, 46 p.

Moore, R.T., Wilson, E.D., and O'Haire, R.T., 1960, Geologic map of Coconino County, Arizona: Tucson, Arizona Bureau of Mines [Arizona Geological Survey] and University of Arizona, 1 sheet, scale 1:375,000.

Mosier, D.L., Singer, D.A., and Cox, D.P., 1986, Grade and tonnage model of sediment-hosted Cu, in Cox, D.P., and Singer, D.A., eds., 1986, Mineral deposit models: U.S. Geological Survey Bulletin 1693, p. 206-208. 
Newhall, C.G., Ulrich, G.E., and Wolfe, E.W., 1987, Geologic map of the southwest part of the San Francisco volcanic field, north-central Arizona: U.S. Geological Survey Miscellaneous Field Studies Map MF-1958, scale 1:50,000, 2 sheets, $58 \mathrm{p}$.

O'Driscoll, Mike, 1990, Minerals in the US south-west: Industrial Minerals, May, 1990, p. 53-87.

Orris, G.J., 1992a, Preliminary constituent models of sodium carbonate (sulfate, chloride) brine, in Orris, G.J., and Bliss, J.D., ed., Industrial mineral deposit models; grade and tonnage models: U.S. Geological Survey Open-File Report 92-437, p. 63-66.

Orris, G.J., 1992b, Preliminary descriptive model of lacustrine borates, in Industrial mineral deposit models--descriptive model for three lacustrine deposit types: U.S. Geological Survey Open-File Report 92-593, p. 2-6.

Orris, G.J., 1992c, Preliminary descriptive model of lacustrine gypsum, in Industrial mineral deposit models--descriptive model for three lacustrine deposit types: U.S. Geological Survey Open-File Report 92-593, p. 7-10.

Orris, G.J., 1992d, Preliminary descriptive model of lacustrine halite, in Industrial mineral deposit models--descriptive model for three lacustrine deposit types: U.S. Geological Survey Open-File Report 92-593, p. 11-13.

Orris, G.J., 1992e, Preliminary grade and tonnage models of marine bedded gypsum, in Orris, G.J., and Bliss, J.D., ed., Industrial mineral deposit models; grade and tonnage models: U.S. Geological Survey Open-File Report 92-437, p. 60-62.

Orris, G.J., and Bliss, J.D., 1989, Industrial-rock and mineral-resourceoccurrence models, in Tooker, E.W., ed., Arizona's industrial rock and mineral resources of Arizona--workshop proceedings: U.S. Geological Survey Bulletin 1905, p 39-44.

Orris, G.J., and Bliss, J.D., eds., 1991, Industrial mineral deposit models-Descriptive deposit models: U.S. Geological Survey Open-File Report 91$11 \mathrm{a}, 78 \mathrm{p}$.

Orris, G.J., and Bliss, J.D., eds., 1992, Industrial mineral deposit models; grade and tonnage models: U.S. Geological Survey Open-File Report 92$437,83 \mathrm{p}$.

Osburn, JoAnne, 1982, Scoria exploration and utilization in New Mexico, in Austin, G.S., ed., Industrial rocks and minerals of the Southwest: New Mexico Bureau Mines \& Mineral Resources Circular 182, p. 57-59. 
Pearthree, P.A., 1993, Geologic and geomorphic setting of the Verde River from Sullivan Lake to Horseshoe Reservoir: Arizona Geological Survey Open-File Report 93-4, 25 p. 5 map sheets, scale 1: 24,000.

Peterson, N.V., and Mason, R.S., 1983, Pumice, pumicite, and volcanic cinders, in Lefond, S.J., ed., Industrial minerals and rocks: New York, Society of Mining Engineers, v. 2, p. 1079-1084.

Phillips, K.A., 1987, Arizona industrial minerals: Phoenix, Arizona, Arizona Department of Mines and Mineral Resources Report 4, 2nd edition, $185 \mathrm{p}$.

Prentice, J.E., 1990, Geology of construction materals: New York, Chapman and Hall, 202 p.

Raup, O.B., 1991, Descriptive model of bedded gypsum; deposit subtype; marine evaporite gypsum (model 35ae), in Orris, G.J., and Bliss, J.D., eds.,Industrial mineral deposit models--descriptive deposit models: U.S. Geological Survey Open-File Report 91-11a, p. 34-35.

Rock, N.M.S., 1988, Numerical geology--a source guide, glossary and selective bibliography to geological uses of computers and statistics: New York, Springer, $427 \mathrm{p}$.

Root, D.H., Menzie, W.D., and Scott, W.A., 1992, Computer Monte Carlo simulation in quantitative resource estimation: Nonrenewable Resources, v. 1 , no. 2 , p. $125-138$.

Schmidt, F.S., 1956, Technology of pumice, pumicite, and volcanic cinders, in Chesterman, C.W., ed., Pumice, pumicite, and volcanic cinders in California: California Divsion of Mines Bulletin 174, p. 99-117.

Scott, D.C., 1992, Mineral appraisal of the Kaibab National Forest, Arizona: U.S. Bureau of Mines Mineral Land Assessment Open File Report MLA 6$92,128 \mathrm{p}$.

Shenk, J.D., 1992, Lacustrine diatomite, in Industrial mineral deposit models-descriptive model for three lacustrine deposit types: U.S. Geological Survey Open-File Report 92-593, p. 23-25.

Singer, D.A., and Cox, D.P., 1988, Application of mineral deposit models to resource assessments: U.S. Geological Survey Year book, Fiscal Year 1987, p. 55-57.

Singer, D.A., and Ovenshine, A.T., 1979, Assessing metallic mineral resources in Alaska: American Scientist, v. 67, no. 5, p. 582-589.

Smith, M.R., and Collis, L., 1993, eds., Aggregates; sand, gravel, and crushed rock aggregates for construction purposes: Bath, United Kingdom, Geological Society Special Publication 9, 539 p. 
Spanski, G.T., 1992, Quantitative assessment of future development of copper/silver resources in the Kootenai National Forest, Idaho/Montana; part 1--estimation of the copper and silver endowments: Nonrenewable Resources, v. 1., no. 2, p. 163-183.

Spunt, E.S., and Brace, W.F., 1974, Direct observation of microcavities in crystalline rock [abs.]: International Journal of Rock Mechanics, v. 11, p. 139-150.

Stein, P.H., 1993, From courthouse to restroom; the Flagstaff sandstone industry: Journal of the West, v. 32, p. 53-61.

Twenter, F.R., and Metzger, D.G., 1963, Geology and ground water in Verde Valley--the Mogollon Rim Region, Arizona: U.S. Geological Survey Bulletin 1177, 129 p.

U.S. Bureau of Mines, 1969, Pozzolanic raw material resources in central and western United States: U.S. Bureau of Mines Information Circular 8421, $117 \mathrm{p}$.

U.S. Bureau of Mines, 1992, Economic analysis of the mineral potential of the East Mojave National Scenic Area, California: U.S. Bureau of Mines Open-File Report OFR 56-92, 78 p.

Ulrich, G.E., and Bailey, N.G., 1987, Geologica map of the SP Mountain part of the San Francisco volcanic field, north-central Arizona: U.S. Geological Survey Miscellaneous Field Studies Map MF-1956, 2 sheets, scale 1:50,000.

Ulrich, G.E., and Bielski, A.M., 1983, Mineral resource potential map of the West Clear Creek Roadless Area, Yavapai and Coconino Counties, Arizona: U.S. Geological Survey Miscellaneous Field Studies Map MF1555-A, scale 1:24,000.

Ulrich, G.E., Billingsley, G.H., Hereford, Richard, Wolfe, E.W., Nealey, L.D., and Sutton, R.L., 1984, Map showing geology, struture, and uranium deposits of the Flagstaff $1^{\circ}$ by $2^{\circ}$ quadrangle, Arizona: U.S. Geological Survey Miscellaneous Investigations Map I-1446, scale 1:250,000, 2 sheets.

Van Gosen, B.S., and Wenrich, K.J., 1989, Ground magnetometer surveys on known and suspected breccia pipes on the Coconino Plateau, northwestern Arizona: U.S. Geological Survey Bulletin 1683-C, 31 p.

Weir, G.W., and Beard, L.S., 1984, Geologic map of the Fossil Springs Roadless Area, Yavapai, Gila, and Coconino Counties, Arizona: U.S. Geological Survey Miscellaneous Field Studies Map MF-1568-C, scale 1:24,000. 
Weir, G.W., Beard, L.S., and Ellis, C.E., 1983, Mineral resource potential map of the Fossil Springs Roadless Area, Yavapai, Gila, and Coconino Counties, Arizona: U.S. Geological Survey Miscellaneous Field Studies Map MF-1568-A, scale 1:24,000.

Weir, G.W., Ulrich, G.E., and Nealey, L.D., 1989, Geologic map of the Sedona $30^{\prime} \mathrm{X} 60^{\prime}$ quadrangle, Yavapai and Coconino Counties, Arizona: U.S. Geological Survey Miscellaneous Investigations Map I-1896, scale 1:100,00

Weisman, W.I., and Mcllveen, Sid, Jr., 1983, Sodium sulfate deposits, in , Lefond, S.J., ed., Indusrial Minerals and Rocks (Nonmetallics other than Fuels): New York, American Institute of Mining, Metallurgical, and Petroleum Engineers, Inc., vol. 2, p. 1207-1223.

Welty, J.W., Reynolds, S.J., and Spencer, J.E., 1989, AZMIN, a digital database compilation for Arizona's metallic mineral districts: Arizona Geological Survey Open-File Report 89-8, pagination varies.

Wenrich, K.J., 1985, Mineralization of breccia pipes in Northern Arizona: Economic Geology, v. 80, no. 6, p. 1722-1735.

Wenrich, K.J., Billingsley, G.H., and Huntoon, P.W., 1986, Breccia pipe and geologic map of the northeastern Hualapai Indian Reservation and vicinity, Arizona: U.S. Geological Survey Open-File Report 86-458-A, 29 p., 2 plates, scale 1:48,000.

Wenrich, K.J., Billingsley, G.H., and Van Gosen, B.S., 1989, The potential of breccia pipes in the National Tank Area, Hualapai Indian Reservation, Arizona: U.S. Geological Survey Bulletin 1683-B, 34 p.

Wenrich, K.J., Van Gosen, B.S., Balcer, R.A., Scott, J.H., Mascarenas, J.F., Beginger, G.M., and Burmaster, Betsi, 1988, A mineralized breccia pipe in Mohawk Canyon, Arizona--lithologic and geophysical logs: U.S. Geological Survey Bulletin 1683-A, 66p.

Wheeler, L.D., Jr., and Williams, J.A., 1974, Soil survey of Long Valley area, Arizona: U.S. Forest Service and Soil Conservation Service in cooperation with Arizona Agricultural Experiment Station, 78 p., 36 sheets, scale 1:31,680, 1 map, scale 1:253,440.

White, T.D., 1991, Aggregate as a component of portland cement and asphalt concrete, in Barksdale, R.D., ed., The aggregate handbook: Washington, D.C., National Stone Association, p. 13-1 to 13-69.

Williams, F.E., and Zinkl, A.V., 1965, Arizona firm mines 200,000 tons of pozzolan for Glen Canyon dam: Rock Products, v. 68, no. 3, p. 97-98. 
Wolfe, E.W., and Hahn, D.A., 1982, Geology and geochemistry of the Strawberry Crater roadless areas, Coconino county, Arizona: U.S. Geological Survey Miscellaneous Field Studies Map MF-1394-A, scale 1:24,000, 1 sheet.

Wolfe, E.W., and Hoover, D.B., 1982, Mineral resource potential map of the Strawberry Crater roadless areas, Coconino county, Arizona: U.S. Geological Survey Miscellaneous Field Studies Map MF-1394-C, scale 1:24,000, 1 sheet, $6 \mathrm{p}$.

Wolfe, E.W., and Light, T.D., 1987, Geophysical map of the Strawberry Crater roadless areas, Coconino county, Arizona: U.S. Geological Survey Miscellaneous Field Studies Map MF-1957, scale 1:50,000, 2 sheets, 85 p.

Wolfe, E.W., Ulrich, G.E., and Newhall, C.G., 1987, Geologic map of the northwest part of the San Francisco volcanic field, north-central Arizona: U.S. Geological Survey Miscellaneous Field Studies Map MF-1957, scale 1:50,000, 2 sheets, $85 \mathrm{p}$.

Wolfe, E.W., Ulrich, G.E., Holm, R.F., Moore, R.B., and Newhall, C.G., 1987, Geologic map of the central part of the San Francisco volcanic field, northcentral Arizona: U.S. Geological Survey Miscellaneous Field Studies Map MF-1959, scale 1:50,000, 2 sheets.

Zdunczyk, M.J., 1991, Importing construction aggregate to the continental United States, in Darkapoulos, Yolanda, ed., Proceedings of an international symposium, Caribbean industrial minerals; new frontiers for investment: Kingston, Jamaica, Symposium, Nov. 13-17, 1989, Journal of the Geological Society of Jamaica, Special Issue No. 11, p., 99-103. 


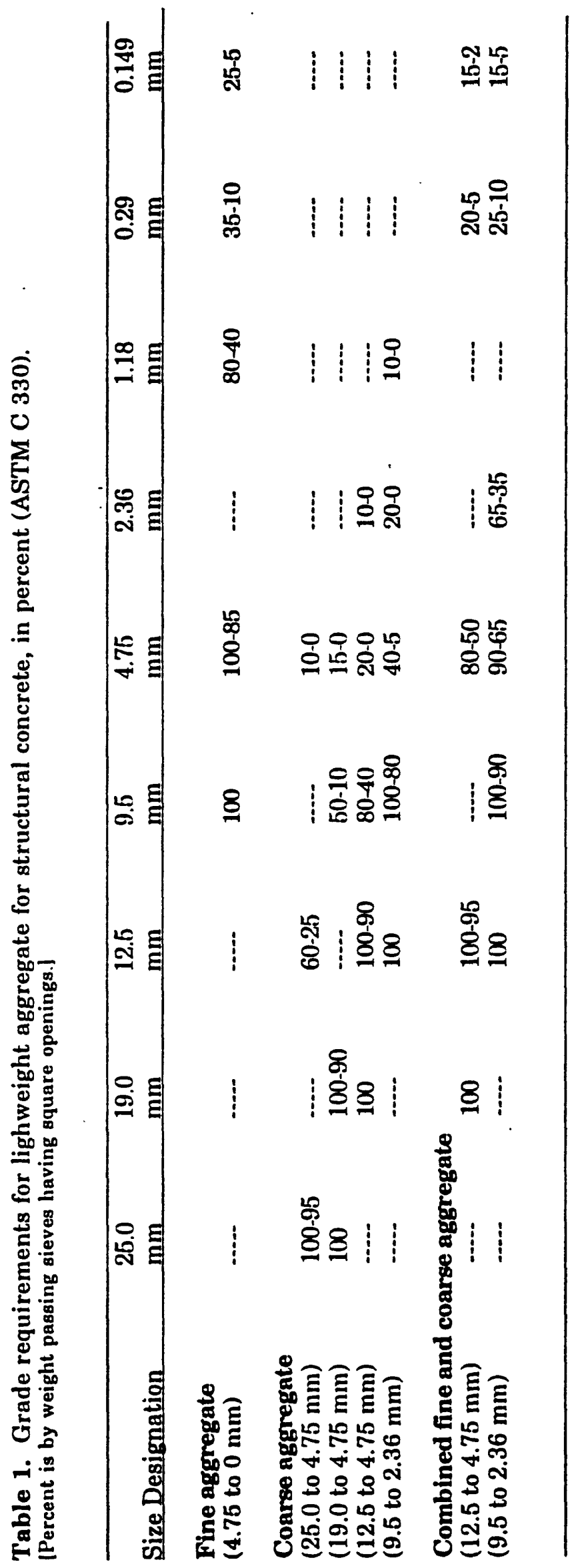




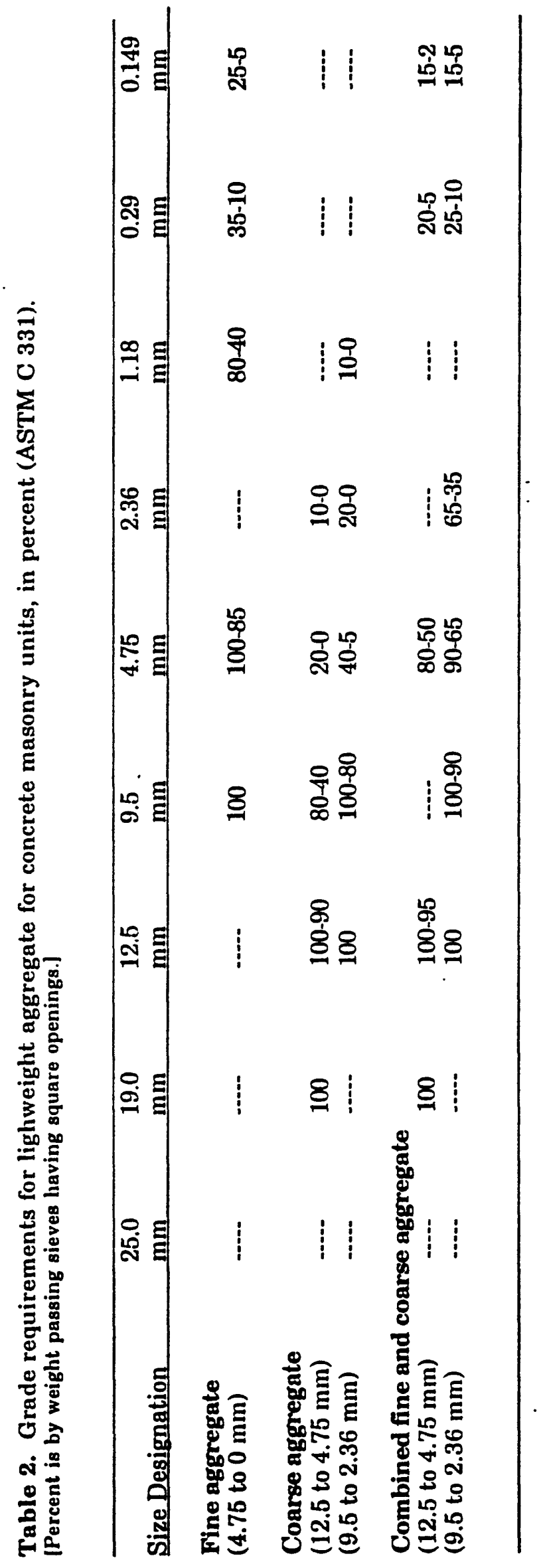




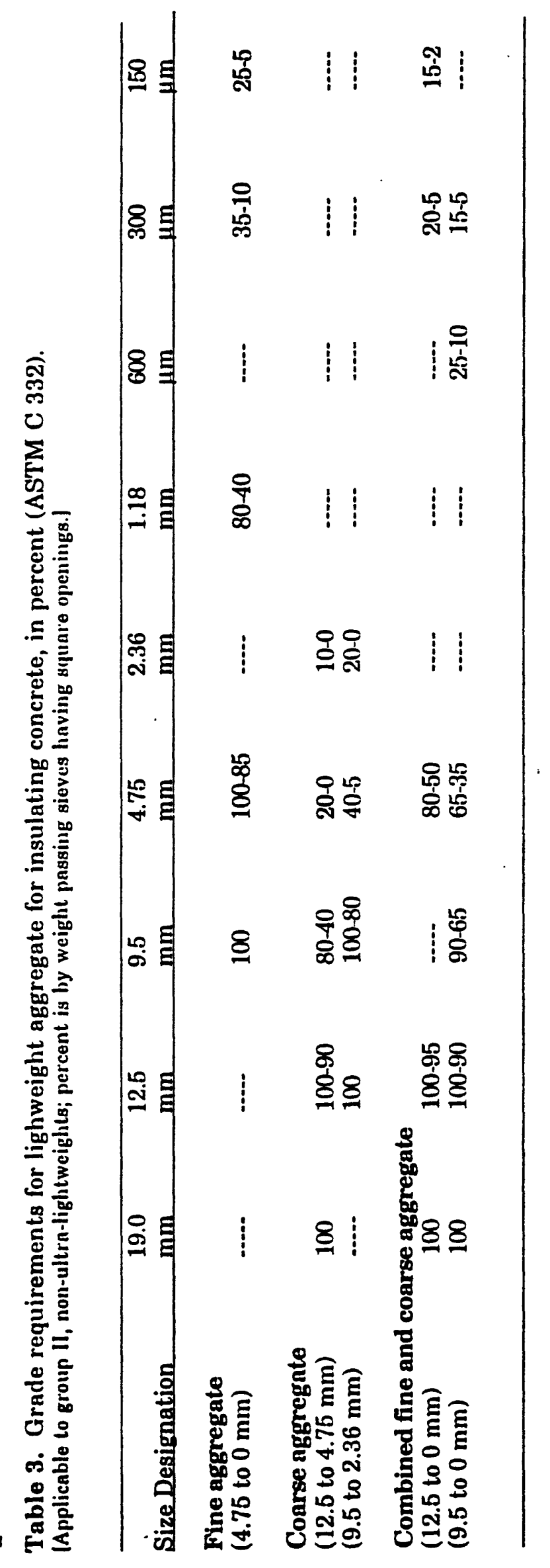




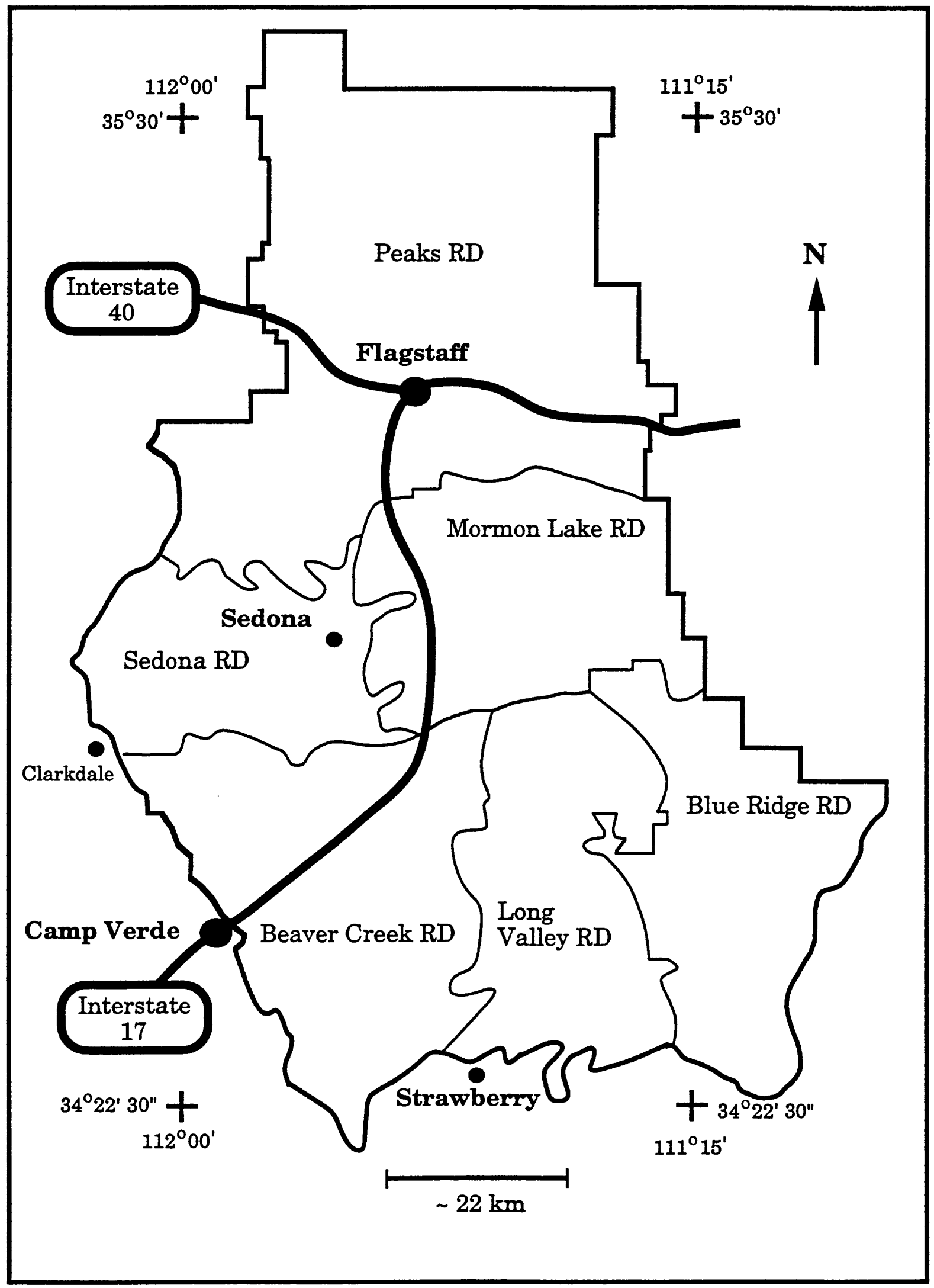

Fig. 1. Location of the six ranger districts of the Coconino National Forest, Arizona. 


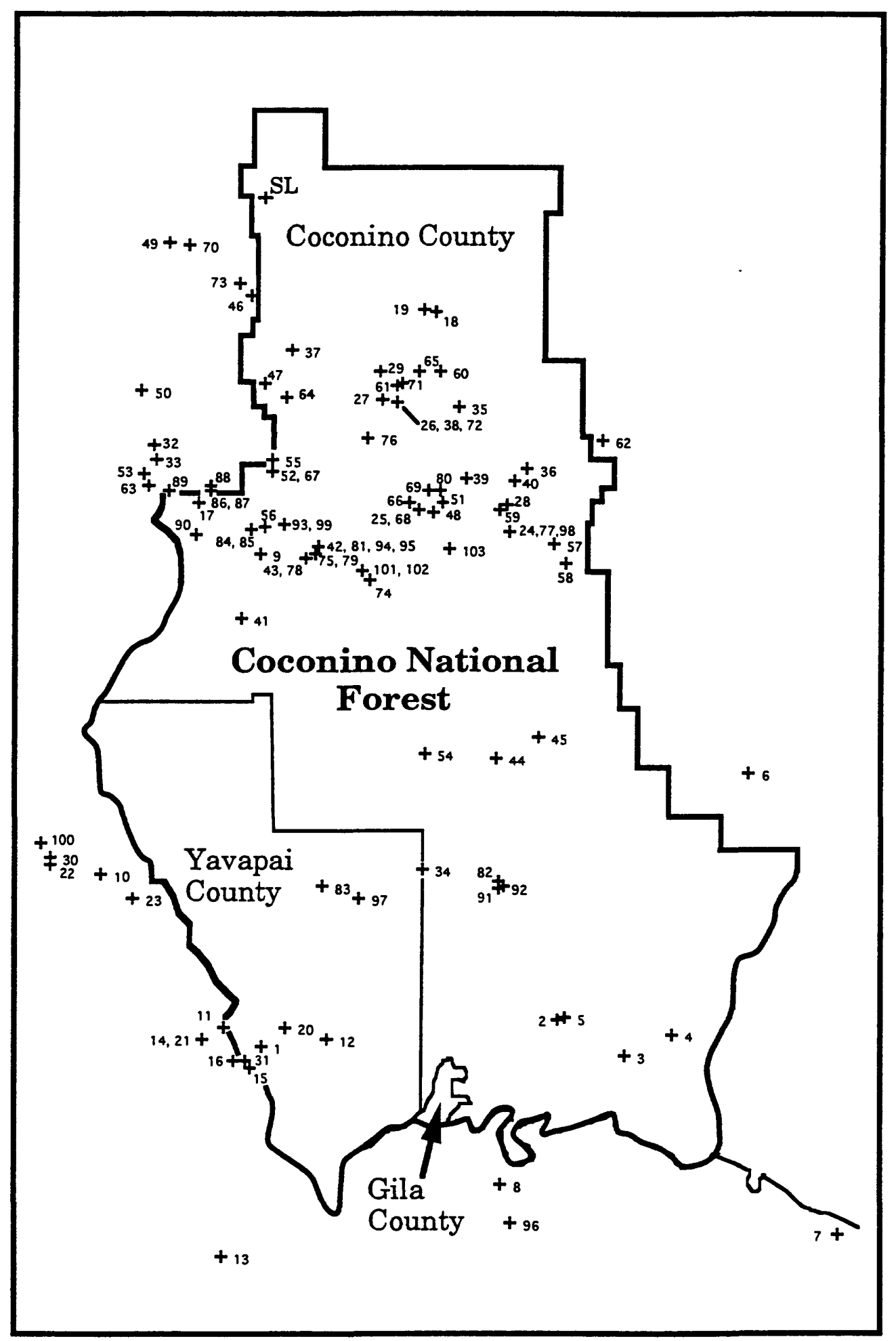

Fig. 2. Location of selected mineral deposits, prospects, and occurrences recorded in MRDS as of May 22, 1995. SL--Slate Mountains, see discussion in text. 


\section{Uses of pumice and pumicite in the USA}

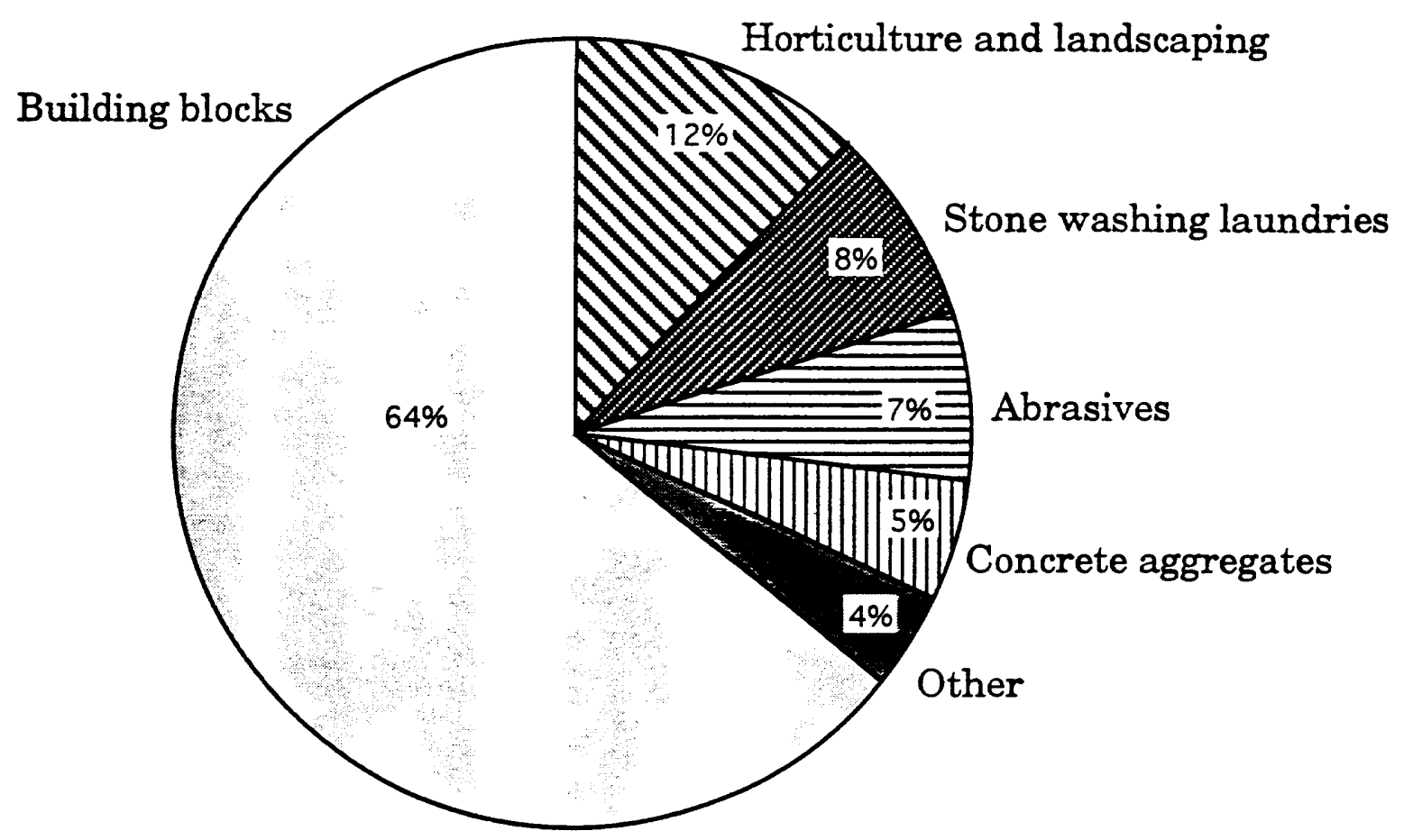

Figure 3. Distribution of uses of pumice and pumicite in the United States in 1993. Class designeated as "Other" includes uses as absorbent, diluents, filter aids, roofing granules, water treatment, and other unspecified uses. Based on data in Bolen (1994). 


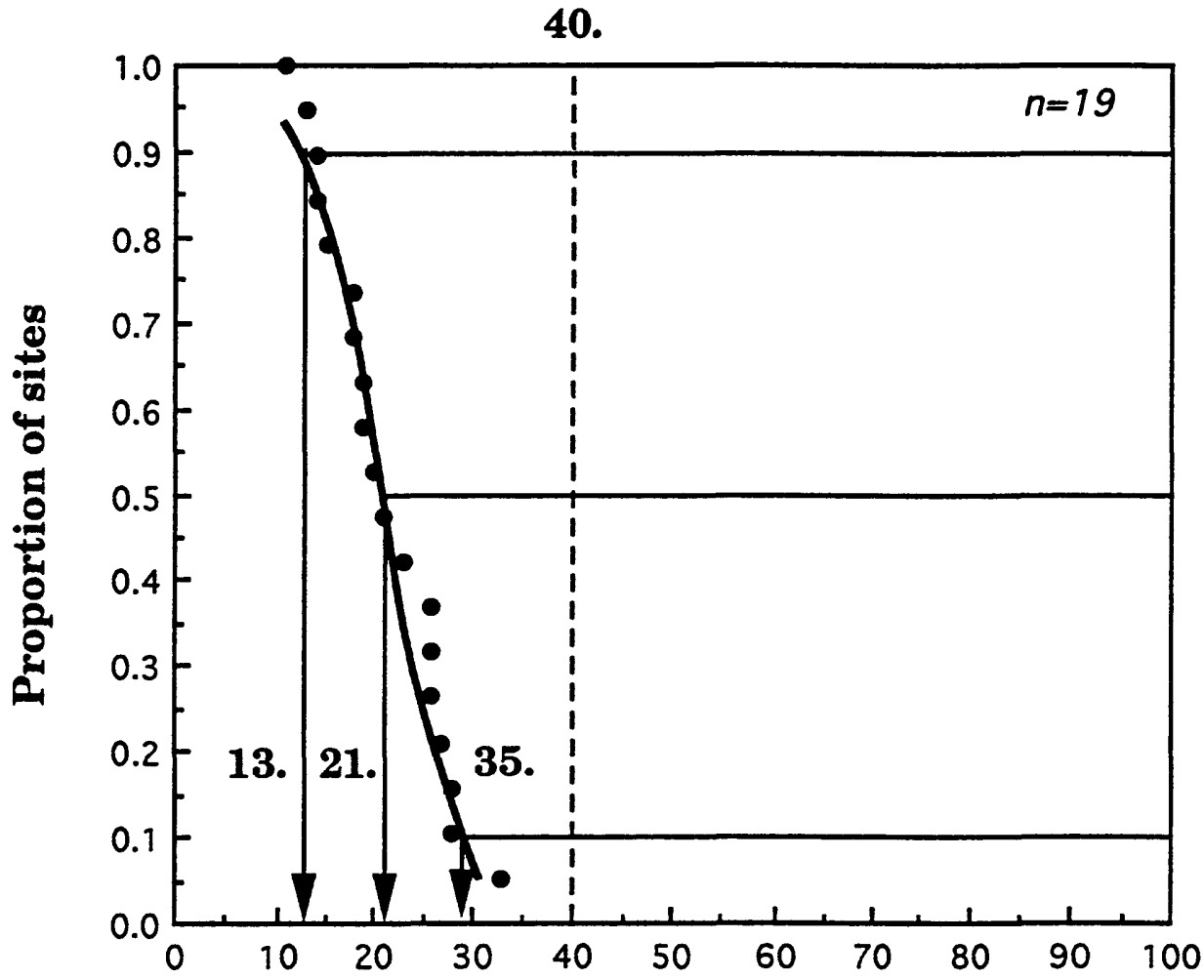

Los Angeles degradation test, percent loss

Figure 4. Degradation of Quaternary and Tertiary basaltic rocks extracted from quarries in Coconino and Yavapai Counties, Arizona $(\mathrm{N}=13)$, and New Mexico $(\mathrm{N}=6)$ as measured by the Los Angeles wear test (500 rotations). Dash line for 40 percent loss which is a common maximum in several ASTM and AASHTO standards for several different uses of aggregates in construction of roads. 


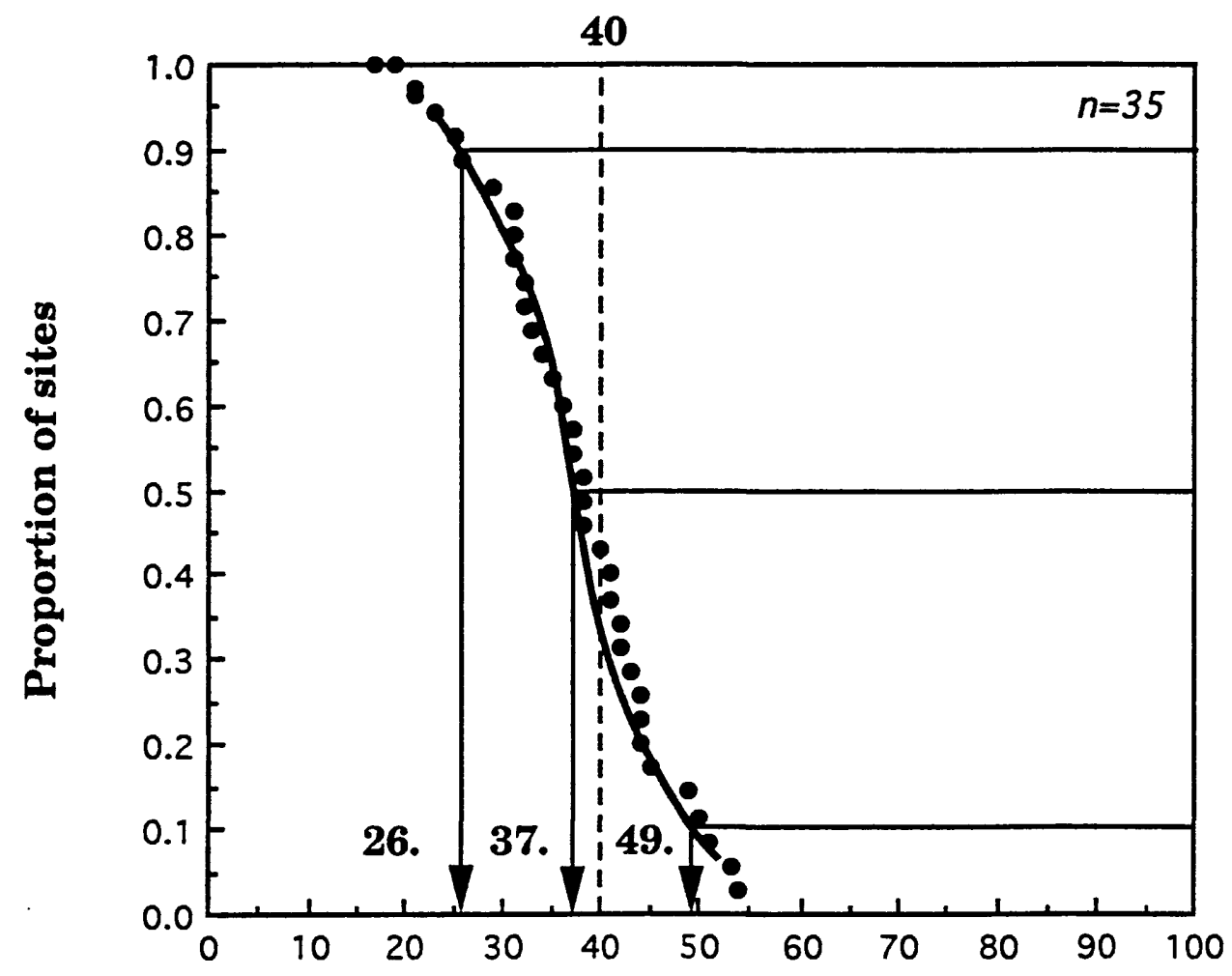

Los Angeles degradation test, percent loss

Figure 5. Degradation of unconsolidated cinders, clinkers, and other Quaternary and Tertiary basaltic material extracted from pits in Northern Arizona as measured by the Los Angeles degradation test (500 rotations). Dash line for 40 percent loss which is a common maximum allowed in several ASTM and AASHTO standards for aggregates used in construction of roads. 


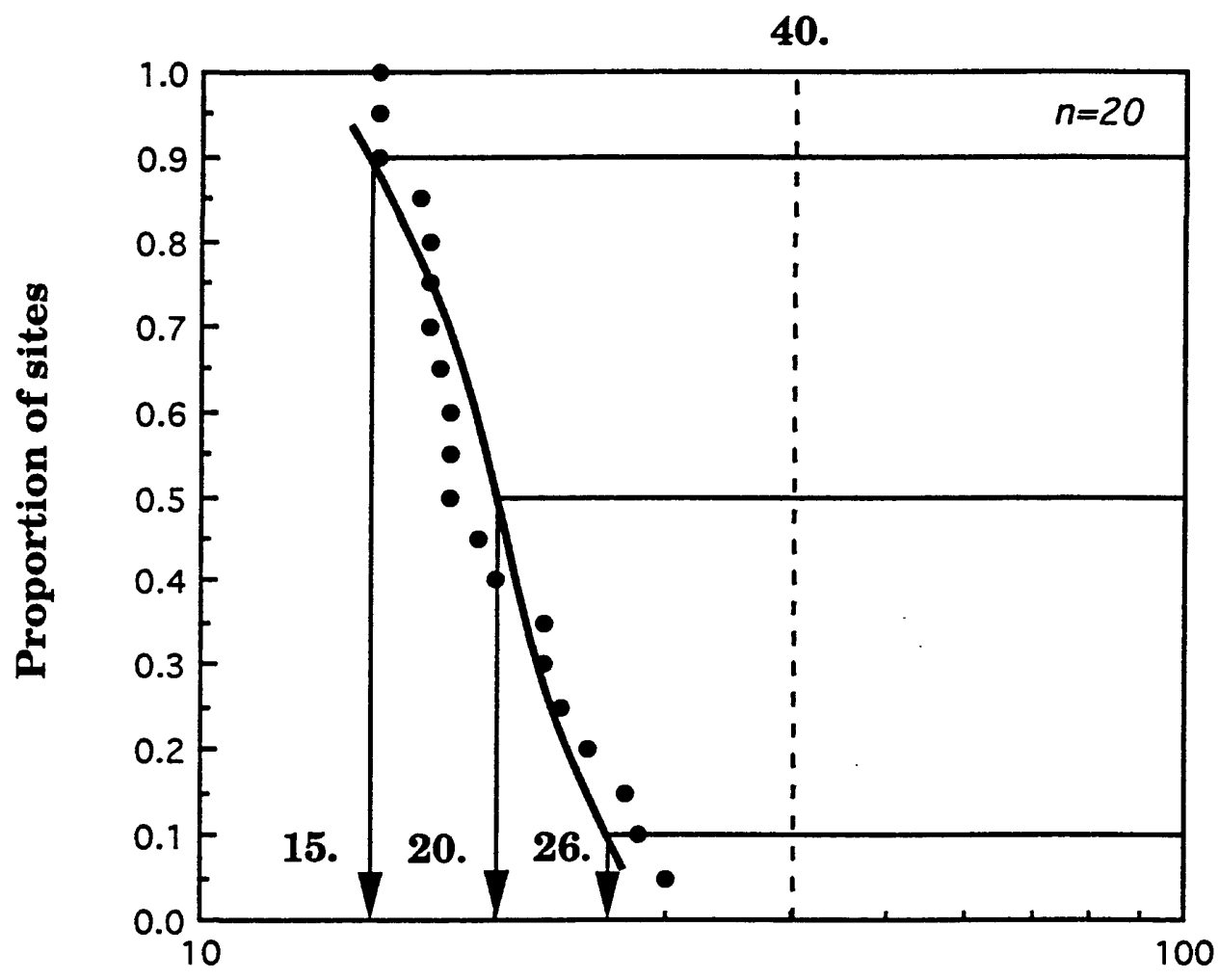

Los Angeles degradation test, percent loss

Figure 6. Probable resistance of rhyolitic rocks in CNF to degradation by abrasion and impact as measured by the Los Angeles degradation test. Based on rhyolites found in New Mexico. Highest and lowest values (not shown) excluded from model (see text). Dash line for 40 percent loss which is a common maximum in several ASTM and ASSHTO standards for several different uses of aggregates in construction of roads. 
40.

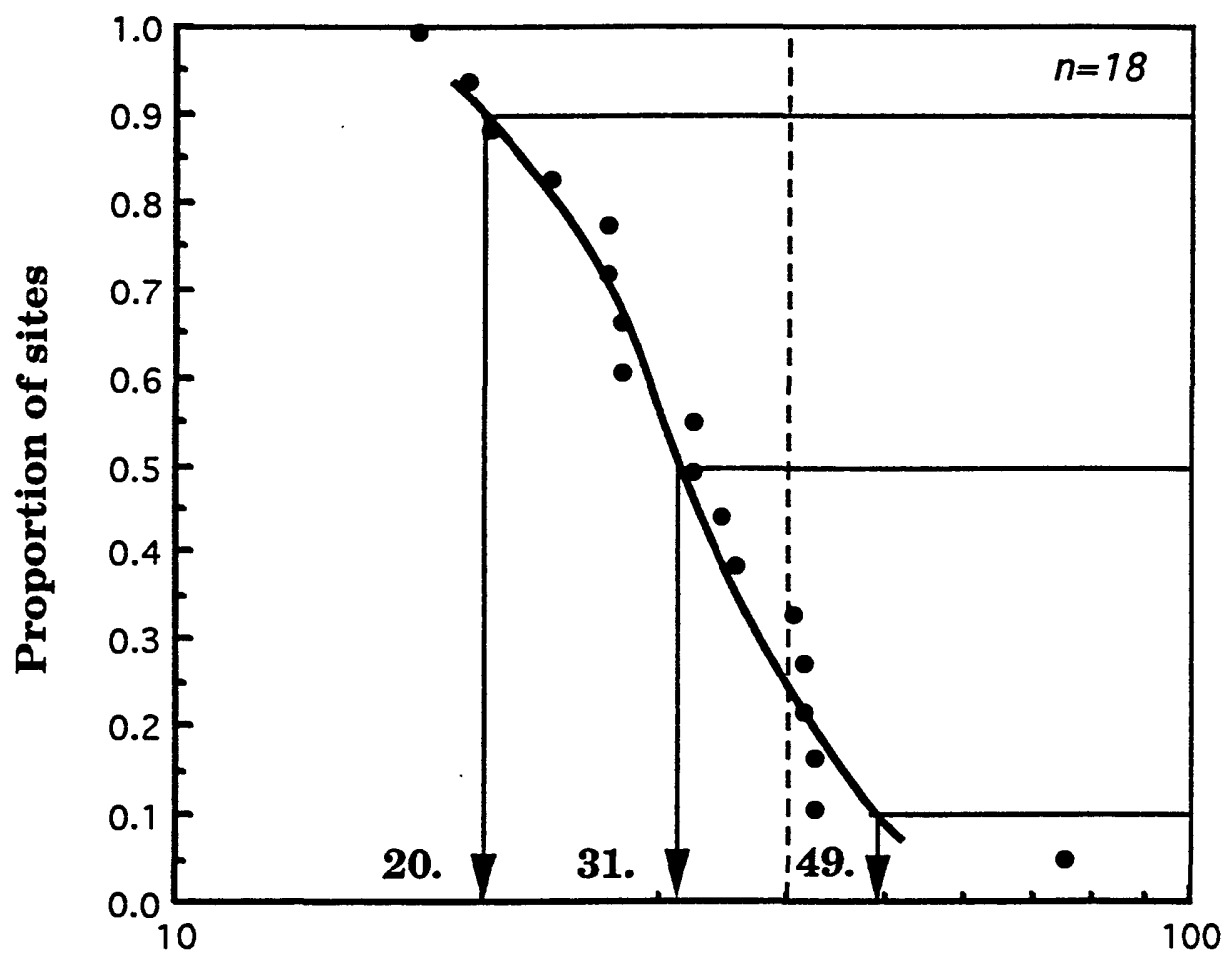

Los Angeles degradation test, percent loss

Figure 7. Probable resistance of rocks from 18 quarries and pits in the Kiabab Formation in, or adjacent to, the CNF. Degradation measured by abrasion and impact in the Los Angeles degradation test (500 rotations). Based on sites in northern Arizona. Dash line for 40 percent loss which is a common maximum in several ASTM and AASHTO standards for several different uses of aggregates in construction of roads. 


\section{Appendix A}

List of MRDS records found in appendix B (which follows) sorted by commodities or byproduct commodities including MRDS sequence numbers. Some records are listed under several different commodities.

Commodity MRDS sequence numbers

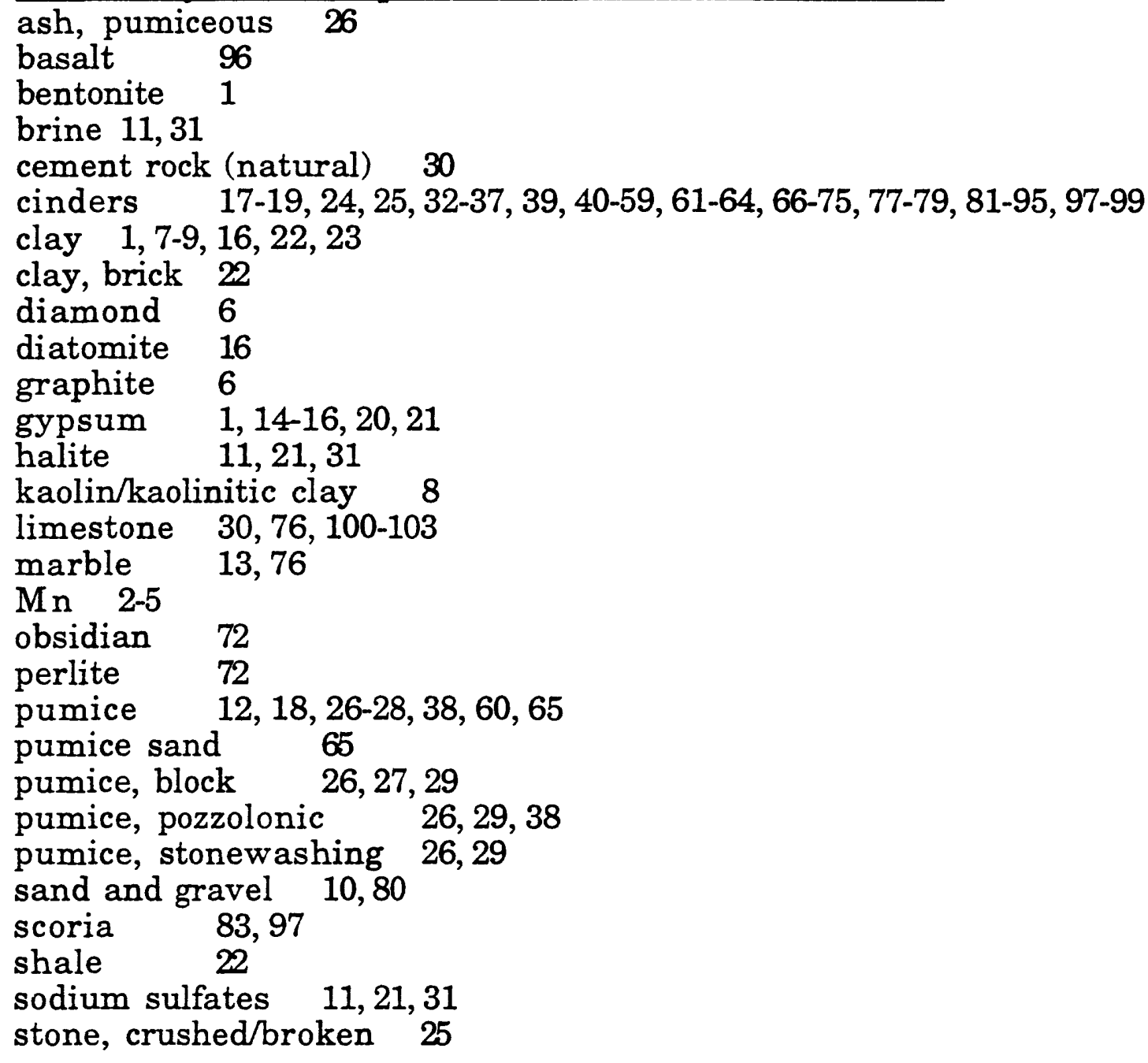




\section{Appendix B}

Descriptions of deposits, prospects, and occurrences of selected minerals found in and adjacent to the CNF and as reported in the Mineral Resources Data System (MRDS) as of May 22, 1995. Sites listed here are also located by sequence number (in upper right-hand corner of each record) on figure 2. MRDS records are listed here in the same order. 


\section{Mineral Resources Data System (MRDS)}

Report Title

Issue Date 00/00/00

Current Date Monday, April 7, 1997

$\begin{array}{ll}\text { Current Time 10:24:50 } & \text { Number } 1 \text { of } 103 \\ \text { Printed } 1 \text { of } 103\end{array}$

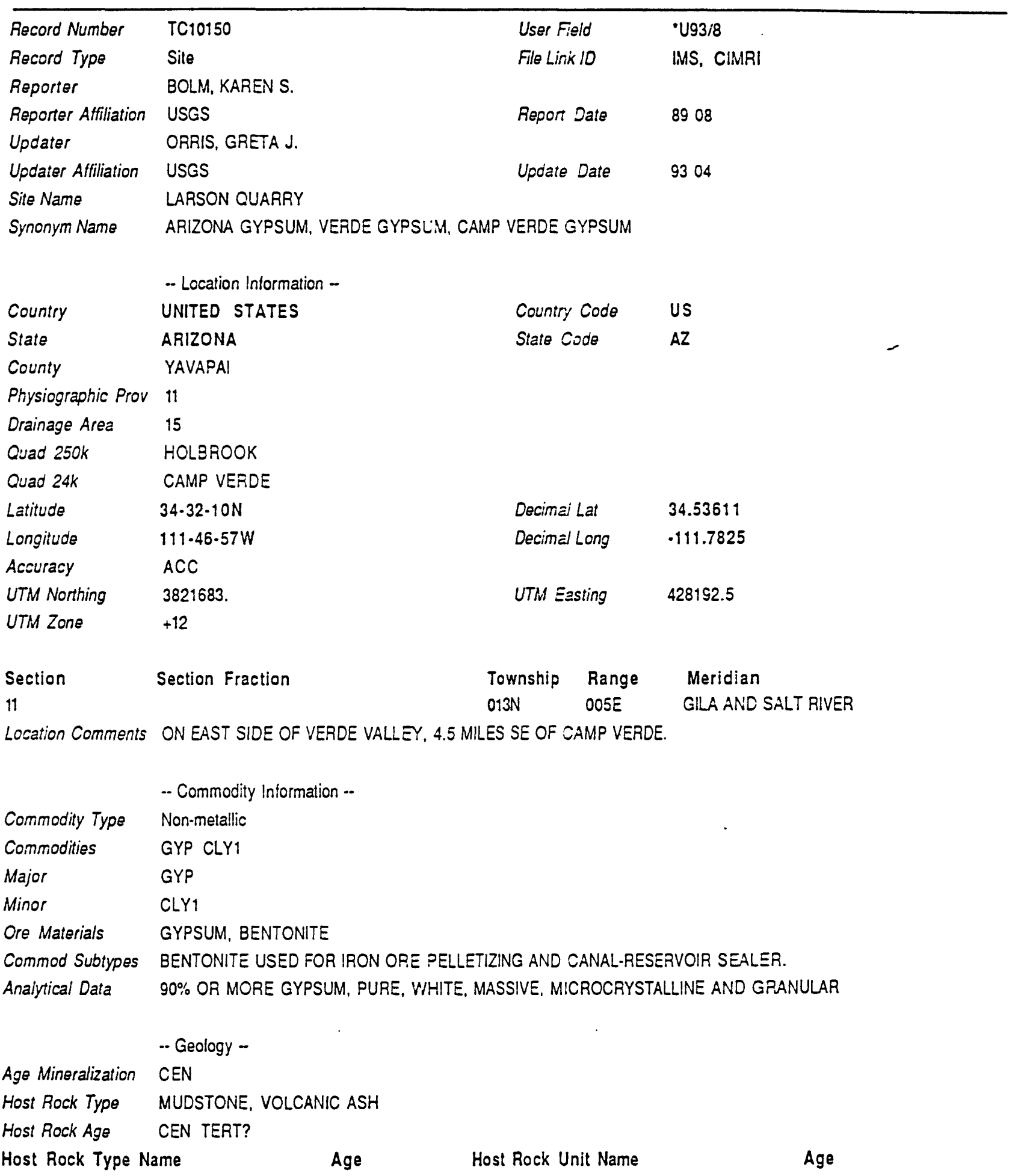

Page 1 


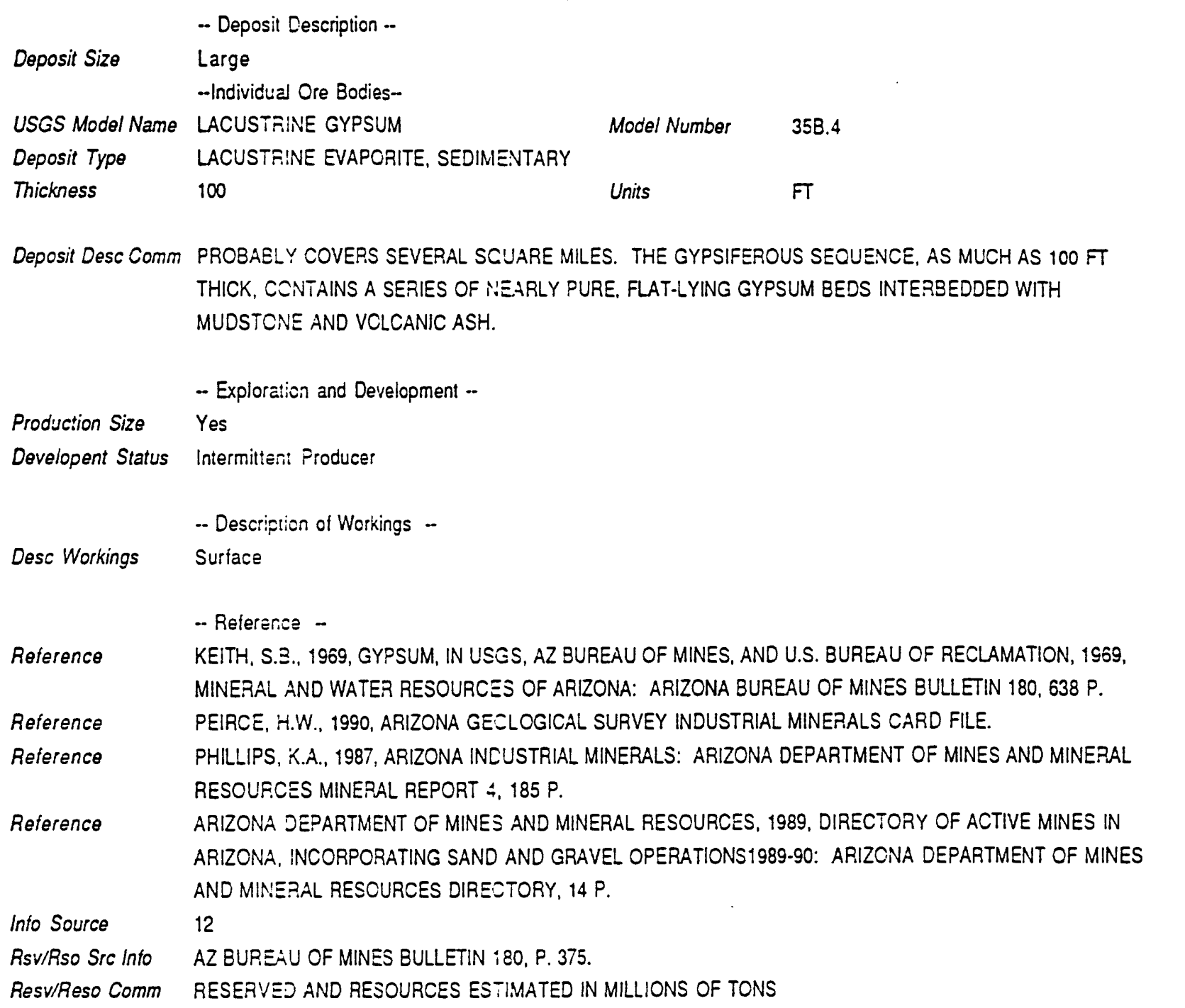

Page 2 


\section{Mineral Resources Data System (MRDS)}

Report Titto

Issue Date 00/00/00

Current Date Monday, April 7, 1997

Current Time 10:24:50

Number 2 of 103

Printed 2 of 103

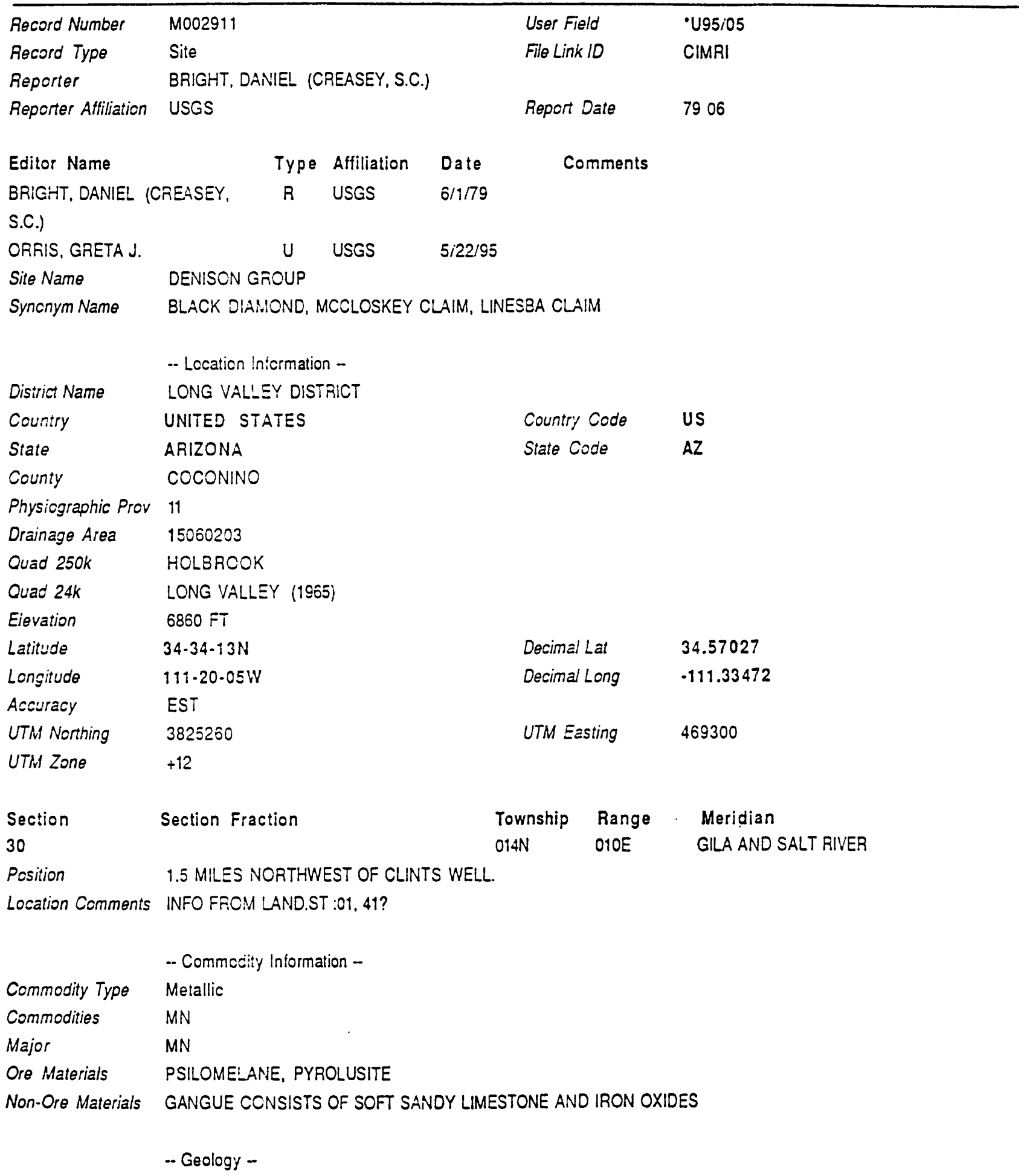




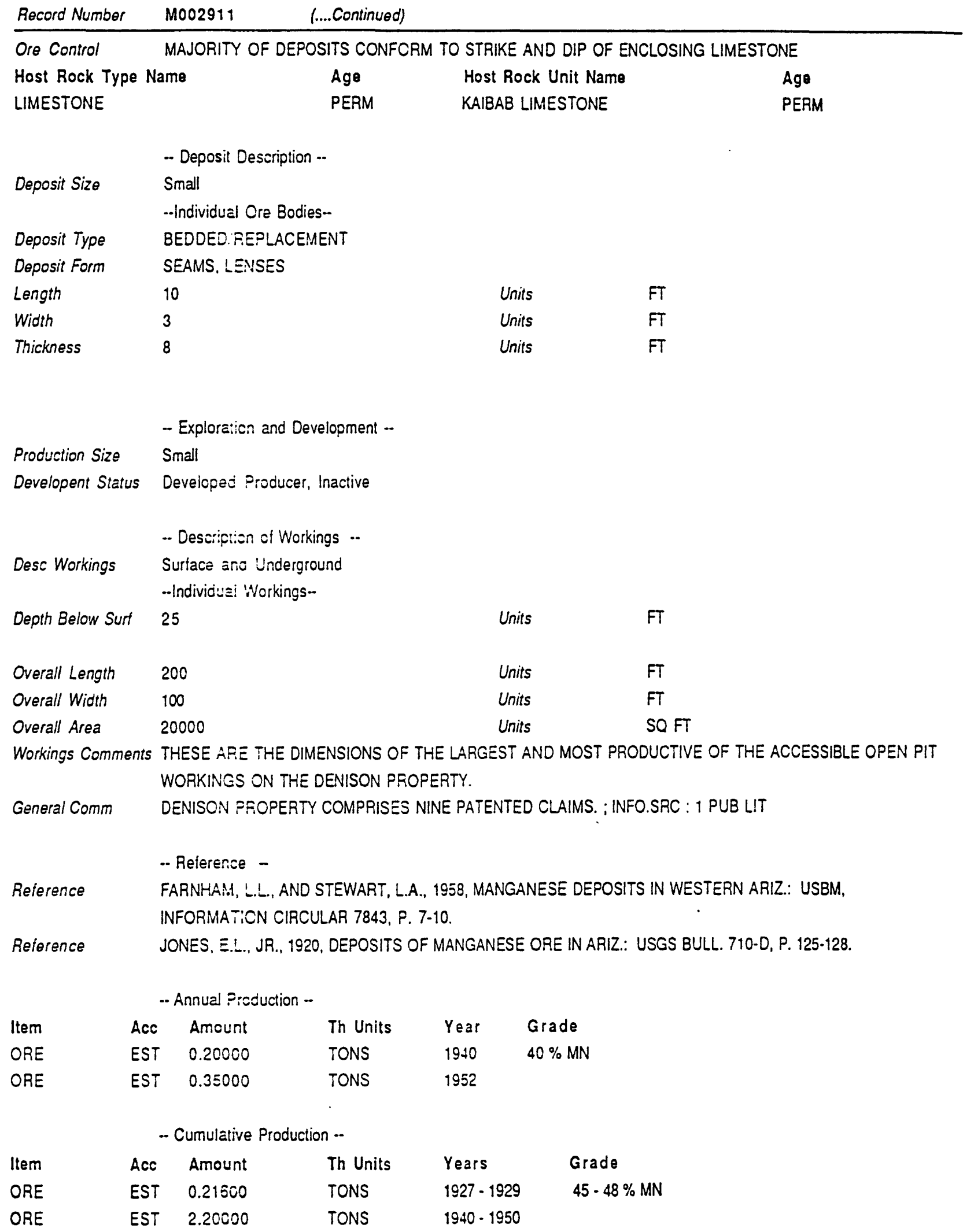


ORE - CON EST 3.70000 TONS

$1927 \cdot 1954$

$40 \% \mathrm{MN}$

Prod Source Info

USBM IC $78+3$

Prod Comments ITEM 10: TOTAL PRODUCTION OF DENISON PROPERTY FROM 1927 - 1954.

Page 3 


\section{Mineral Resources Data System (MRDS)}

Report Title

Issue Date Monday, March 9, 1992

Number 3 of 103

Current Date Monday, April 7, 1997

Current Time 10:24:50

Printed 3 of 103

\begin{tabular}{|c|c|c|c|c|}
\hline Record Number & M002930 & \multicolumn{2}{|c|}{ User Field } & \\
\hline Record Type & Site & \multicolumn{2}{|c|}{ File Link 10} & \\
\hline Reporter Affiliation & USES & \multicolumn{2}{|c|}{ Report Date } & \\
\hline Updater & BRIGHT, DANIEL; CREASEY, S. C. & & & \\
\hline Updater Affiliation & & \multicolumn{2}{|c|}{ Update Date } & 7906 \\
\hline \multirow[t]{2}{*}{ Site Name } & \multicolumn{3}{|l|}{ LOST APACHE CLAIM } & \\
\hline & \multicolumn{3}{|l|}{ - Location Information - } & \\
\hline District Name & \multicolumn{4}{|l|}{ LONG VALIEY DISTRICT } \\
\hline Country & UNITED STATES & \multicolumn{2}{|c|}{ Country Code } & US \\
\hline State & ARIZONA & \multicolumn{2}{|c|}{ State Code } & $A Z$ \\
\hline County & \multicolumn{3}{|l|}{ COCONINO } & \\
\hline Physiographic Prov & \multicolumn{3}{|l|}{11} & \\
\hline Drainage Area & \multicolumn{3}{|l|}{15020008} & \\
\hline Land Status & \multicolumn{3}{|l|}{41} & \\
\hline Quadrangle & BLUE RIDGE RESERVOIR (1965) & \multirow{2}{*}{\multicolumn{2}{|c|}{ Scale }} & 24000 \\
\hline Quad 250k & \multirow{2}{*}{\multicolumn{3}{|c|}{$\begin{array}{l}\text { Holbrook } \\
7040 \mathrm{FT}\end{array}$}} & \\
\hline Elevation & & & & \\
\hline Latitude & $34 \cdot 31 \cdot 31 N$ & \multicolumn{2}{|c|}{ Decimal Lat } & 34.52527 \\
\hline Longitude & $111 \cdot 13.49 \mathrm{~W}$ & \multicolumn{2}{|c|}{ Decimal Long } & .111 .23027 \\
\hline UTM Northing & 3820230 & \multicolumn{2}{|c|}{ UTM Easting } & 478870 \\
\hline UTM Zone & \multicolumn{3}{|l|}{+12} & \\
\hline Section & \multirow[t]{2}{*}{ Section Fraction } & Township & Range & Meridian \\
\hline 07 & & $013 \mathrm{~N}$ & O11E & $G \& S R$ \\
\hline Position & \multicolumn{4}{|c|}{ 3.9 MILES SOUTHWEST OF BLUE RIDGE SPILLWAY } \\
\hline \multirow[t]{2}{*}{ Location Comments } & \multicolumn{4}{|l|}{ UTM EST } \\
\hline & \multicolumn{3}{|l|}{-- Commodity Information -- } & . \\
\hline Commodities & \multicolumn{3}{|l|}{$M N$} & \\
\hline Major & \multicolumn{3}{|l|}{ MN } & \\
\hline \multirow[t]{2}{*}{ Ore Materials } & PSILOMELANE & & & \\
\hline & - Geology -- & & & \\
\hline Host Rock Type & RESIDUAL SOIL FROM CLAYEY, & IPOSED LIME & STONE & \\
\hline Host Rock Age & PERM & & & \\
\hline & - Deposit Description -- & & & \\
\hline Deposit Size & Small & & & \\
\hline & -Individual Ore Bodies- & & & \\
\hline
\end{tabular}

Page 1 


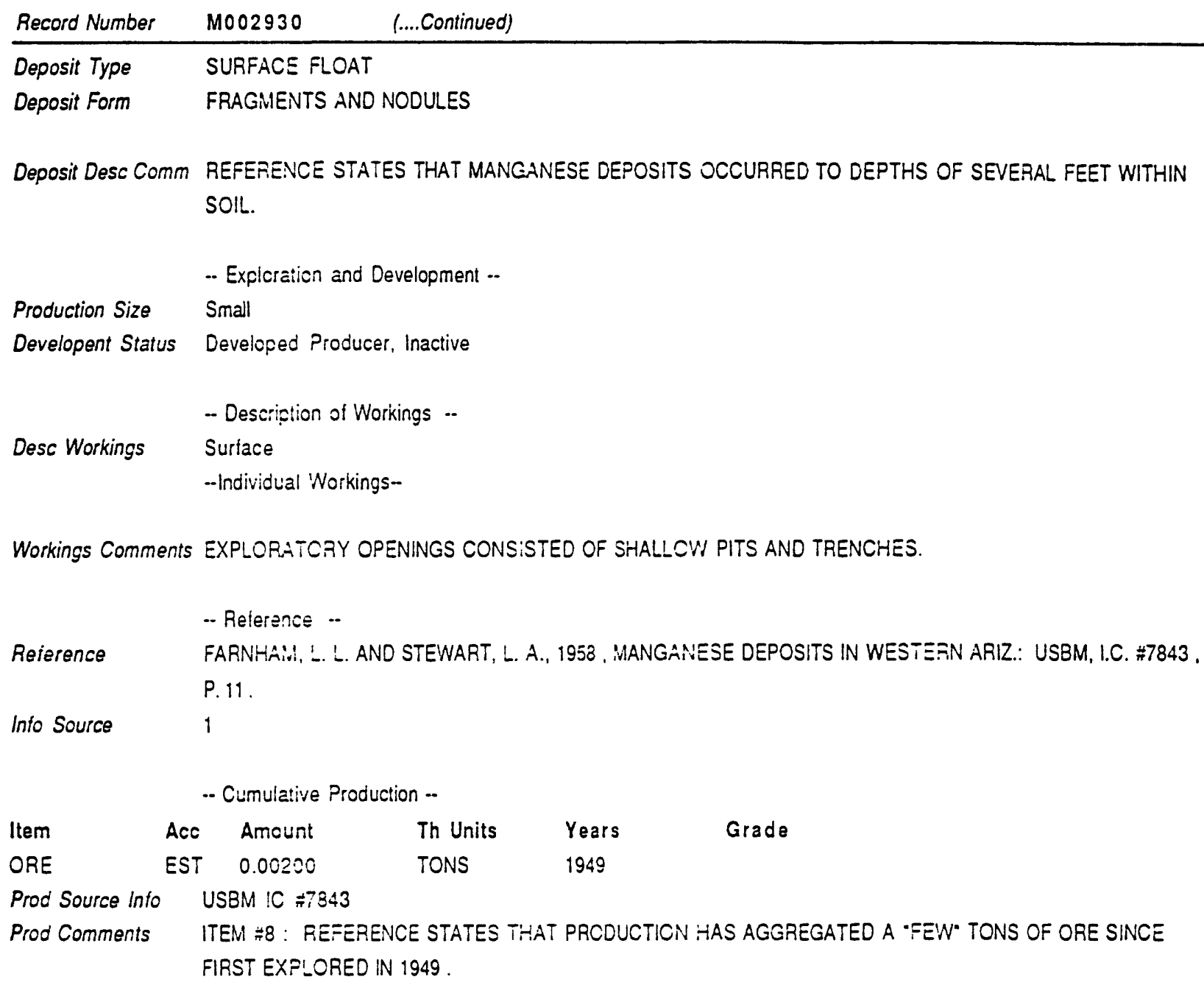

Paye 2 


\section{Mineral Resources Data System (MRDS)}

Report Title

Issue Date Monday, March 9, 1992

Number 4 of 103

Current Date Monday, April 7, 1997

Current Time 10:24:50

Printed 4 of 103

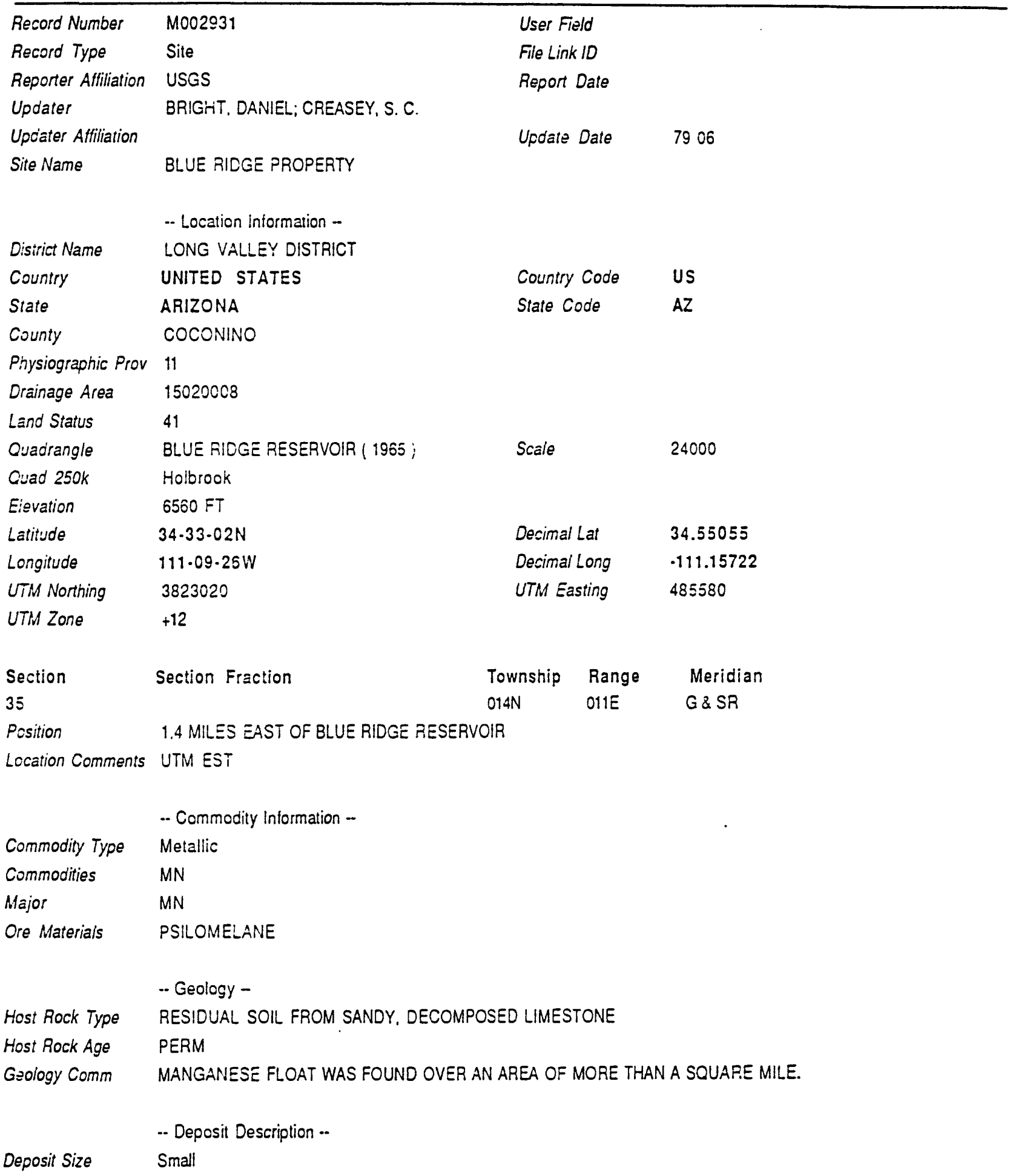




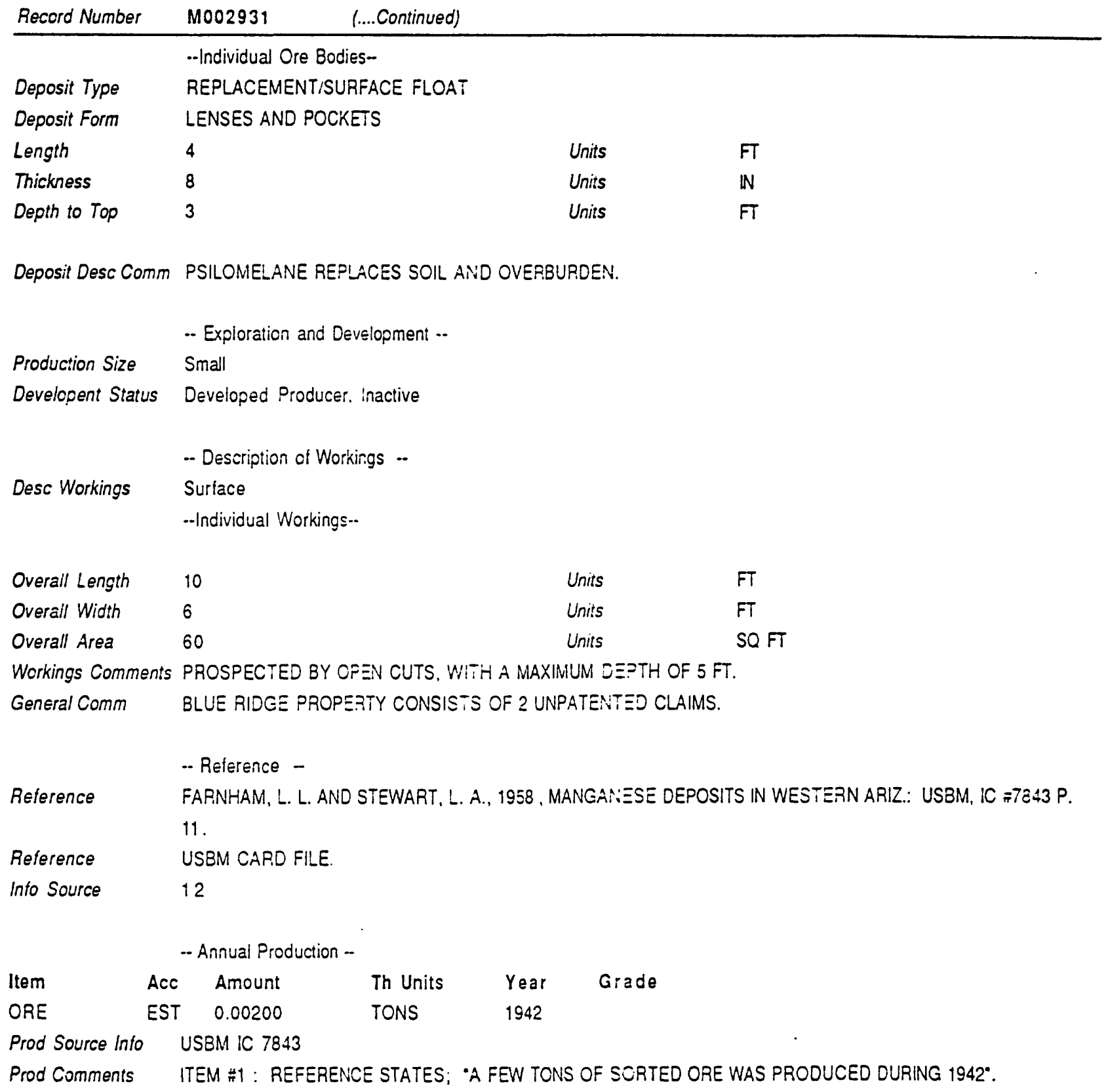




\section{Mineral Resources Data System (MRDS)}

Report Title

Issue Date 00/00/00

Current Date Monday, April $; .1997$

Number 5 of 103

Printed 5 of 103

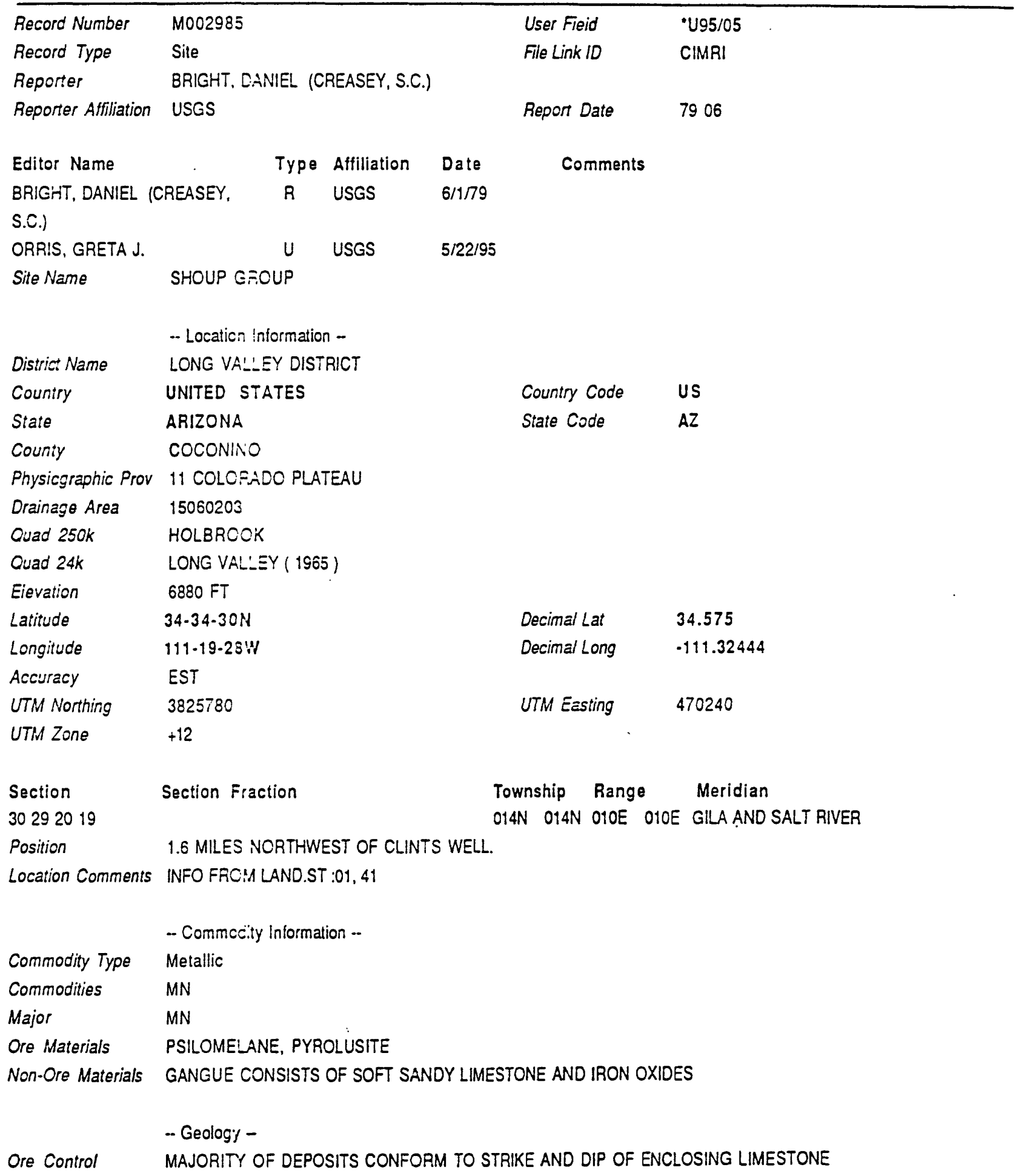

Page 1 


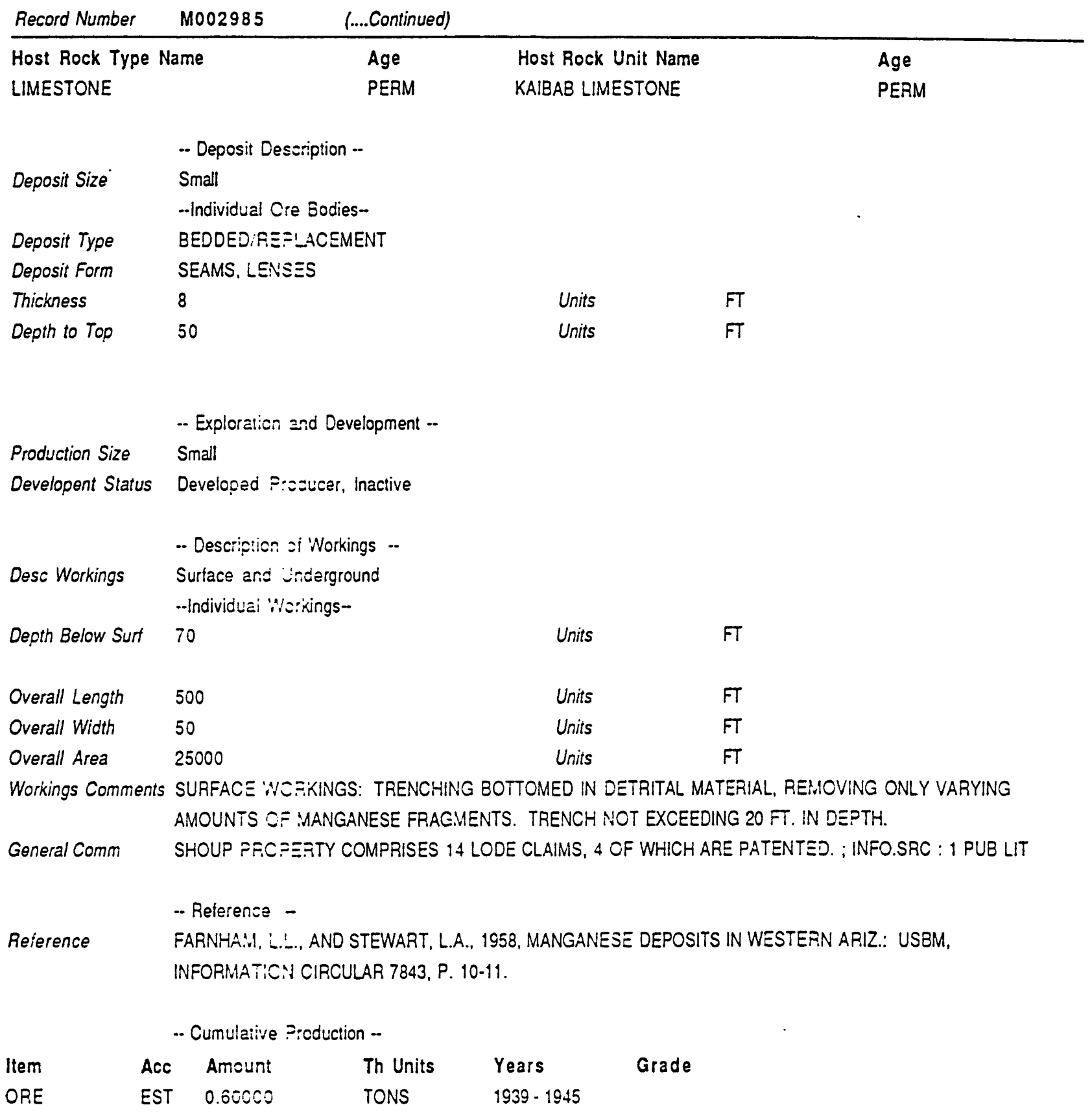




\section{Mineral Resources Data System (MRDS)}

Report Titlo

Issue Date 00/00/00

Current Date Monday, April 7, 1997

Number 6 of 103

Record Number

TC00275

Current Time 10:24:50

Printed 6 of 103

Record Type Site

User Field

File Link 10

$\cdot 93 / 4$

Reporter

WELLS, T.M., (ORRIS, G.J.)

Reporter Affiliation

USGS

Report Date

IMS, CIMRI

Site Name

DIAMOND OCCURRENCES

- Location information -

Country

UNITED STATES

Country Code

US

State

ARIZONA

State Code

AZ

County

COCONINO

Physiographic Prov 11

Land Status

11

Quad 250k

00

Quad 24k

HOLBRCOK

Other Quad Name

CHAVEZ MTN NE

Latitude

CHAVEZ MTN EAST

Scale

24000

Longitude

34.53.00N

Decimal Lat

34.88333

Accuracy

$111.02 .30 \mathrm{~W}$

Decimal Long

.111 .04160

UTM Northing

EST

3859908 .

UTM Easting

496192.3

UTM Zone

$+12$

Section

Section Fraction

Township Range

Meridian

$17 \mathrm{~N} \quad$ 12.5E

GILA AND SALT RIVER

Location Comments NEAR DCG VALLEY. LAT-LONG TAKEN FROM SECS. 2, 11. IN CANYON DIABLO.

-. Commodity Information -.

Commodity Type

Non-metallic

Commodities

DIA GRF

Occurring

DIA GRF

Ore Materials

DIAMONDS, GRAPHITE

Commod Comments

SMALL BLACK DIAMONDS AND GRIAPHITE AS SMALL NODULES.

-. Geology -.

-- Deposit Description -.

Deposit Desc Comm IN 1891 A 40 LB MASS OF THE CANYON DIABLO METEORITE WAS FOUND TO CONTAIN TINY BLACK DIAMONDS. SUBSEQUENTLY, SHALL DIAMONDS EMBEDDED IN GRAPHITE HAVE BEEN FOUND IN OTHER FRAGMENTS FROM THE SAME FALL. SMALL GRAPHITE NODULES ARE ALSO CONTAINED IN THE DIABLO CANYON METEORITE FRAGMENTS.

-. Expioration and Development .- 
Production Size U

Developent Status Prospect, Inactive

- Description of Workings -

- Reference -

Reference MINERALOGY OF ARIZONA, 1977, P. 94.

Reference PEIRCE, H.W., 1990, ARIZONA GECLOGICAL SURVEY INDUSTRIAL MINERALS CARD FILE.

Info Source 1

Page 2 


\section{Mineral Resources Data System (MRDS)}

Report Title

Issue Date 00/00/00

Current Date Monday, April 7, 1997

\begin{tabular}{cl} 
Current Time 10:24:50 & $\begin{array}{c}\text { Number } 7 \text { of } 103 \\
\text { Printed } 7 \text { of } 103\end{array}$ \\
\hline $\begin{array}{l}\text { User Field } \\
\text { File Link ID }\end{array}$ & $\begin{array}{c}\cdot 93 / 9 \\
\text { IMS, CIMRI }\end{array}$ \\
Report Date & 93 09 \\
& \\
& \\
Country Code & US \\
State Code & AZ \\
& \\
Decimal Lat & 34.29583 \\
Decimal Long & -110.90555 \\
UTM Easting & 508691.5 \\
&
\end{tabular}

\begin{tabular}{ll}
\hline Record Number & TC38875 \\
Record Type & Site \\
Reporter & ORRIS. GRETA G. \\
Reporter Affiliation & USGS \\
Site Name & CHRIS CLAY DEPOSIT
\end{tabular}

$\begin{array}{ll} & \text { - Location Inicrmation - } \\ \text { Country } & \text { UNITED STATES } \\ \text { State } & \text { ARIZONA } \\ \text { Quad 250K } & \text { HOLBRCOK } \\ \text { Latitude } & 34 \cdot 17-45 \mathrm{~N} \\ \text { Longitude } & 110 \cdot 54-20 \mathrm{~W} \\ \text { UTM Northing } & 3794766 . \\ \text { UTM Zone } & +12 \\ & \\ \text { Section } & \text { Section Fraction }\end{array}$

-. Commedity Information --

Commodity Type

Commodities

Non-metallic

Major

CLY

CLY

-. Geology -

- Deposit Description --

-Individual Ore Bodies-

Deposit Type SEDIMENTARY?

\footnotetext{
- Exploration and Development -.

Production Size No

Developent Status Occurrence

- Description of Workings --

- Reference -
} 


\section{Mineral Resources Data System (MRDS)}

Report Title

Issue Date 00100/00

Current Date Monday, April 7, 1997

Current Time 10:24:50

Number 8 of 103

Record Number TC38873

Record Type Site

User Field $\quad$ 93/9

Reporter

ORRIS. GRETA G.

Reporter Affiliation USGS

File Link 10

IMS, CIMRI

Site Name

FLORENCE CERAMICS

Report Date

9309

-- Location Information -.

Country UNITED STATES

ARIZONA

$\begin{array}{ll}\text { Quad 250K } & \text { HOLBRCOK } \\ \text { Latitude } & 34.21 \cdot 38 \mathrm{~N}\end{array}$

$111 \cdot 25 \cdot 10 \mathrm{~W}$

3802018.

$+12$

UTM ZOne

Section

Section Fraction

Township Range

Meridian

GILA AND SALT RIVER

$\begin{array}{ll}\text { Country Code } & \text { US } \\ \text { State Code } & \mathrm{AZ} \\ \text { Decimal Lat } & 34.36055 \\ \text { Decimal Long } & -111.41944 \\ \text { UTM Easting } & 461428.6 \\ & \\ & \\ \text { Wnship Range } & \text { Meridian } \\ & \text { GILA AND SALT RIVER }\end{array}$

-. Commecity Information .-

Commodity Type

Non-metallic

Commodities

CLY3

Major

CLY3

- Geology -

-. Deposit Description .-

-. Exploration and Development --

Production Size

Small

Developent Status

Little Developed Producer, Inactive

- Description of Workings --

Desc Workings Surface

-. Reference - 


\section{Mineral Resources Data System (MRDS)}

Report Title

Issue Date 00/00/00

Current Date Monday, April 7, 1997

Current Time 10:24:50

Number 9 of 103

Record Number TC00253

Record Type

Site

Reporter

WELLS, T.M. (ORRIS, G.J.)

Reporter Affiliation

USGS

Updater

ORRIS, GRETA J.

Updater Affiliation

USGS

ROGERS LAKE

Site Name

-- Location Information -

Country

State

County

UNITED STATES

ARIZONA

COCONINO

Physiographic Prov

Administrative Area

Quad 250k

Quad 100k

Quad 62.5k

Quad 24k

Latitude

Longitude

Accuracy

UTM Northing

UTM Zone

Section

31, 32

Location Comments

Section Fraction

COCONINO NATIONAL FOREST

FLAGSTAFF

FLAGSTAFF

BELLEMONT

BELLEMCNT

$35-09-55 \mathrm{~N}$

$111.47-20 \mathrm{~W}$

ESTIMATED LOCATION, WITHIN I MILE. 3891458 .

$+12$

Commodity Type

-- Commodity Information --

Commodities

Non-metalic

Major

CLY

CLY

Ore Materials

CLAY

-. Geology -

Host Rock Type

ANDESITE, BASALT

- Deposit Description --

--Individual Ore Bodies-

Deposit Type

RESIDUAL
User Field

File Link 10

Repcrt Date

Update Date

Country Code US

State Code

AZ

-U93/8

IMS, CIMRI

9206

9304

Printed 9 of 103 
Deposit Desc Comm HIGH.SILICA CLAY DERIVED FROM DECOMPOSED ANDESITE AND BASALT.

- Exploration and Development -.

Production Size

No

Developent Status

Occurrence

-Description of Workings -

- Relerence -

Reference ELEVATORSKI, EA., 1978, ARIZONA INDUSTRIAL MINERALS: ARIZONA DEPAFTMIIENT OF MINES AND MINERAL RESOURCES REPORT 2.

Reference PEIRCE. H.W.. 1990, ARIZONA GECLOGICAL SURVEY INDUSTRIAL MINERALS CARD FILE.

Reference PHILLIPS, K.A., 1987, ARIZONA INCUSTRIAL MINERALS: ARIZONA DEPARTMENT OF MINES AND MINERAL RESOURCES MINEPAL REPORT $4,185 \mathrm{P}$.

Info Source 1

Prod Comments NO PRODUCTION REPORTED.

$$
\text { Page } 2
$$




\section{Mineral Resources Data System (MRDS)}

Report Title

Issue Date 00100100

Current Date Monday, April 7. 1997

Current Time 10:24:50

Number 11 of 103

Printed 11 of 103

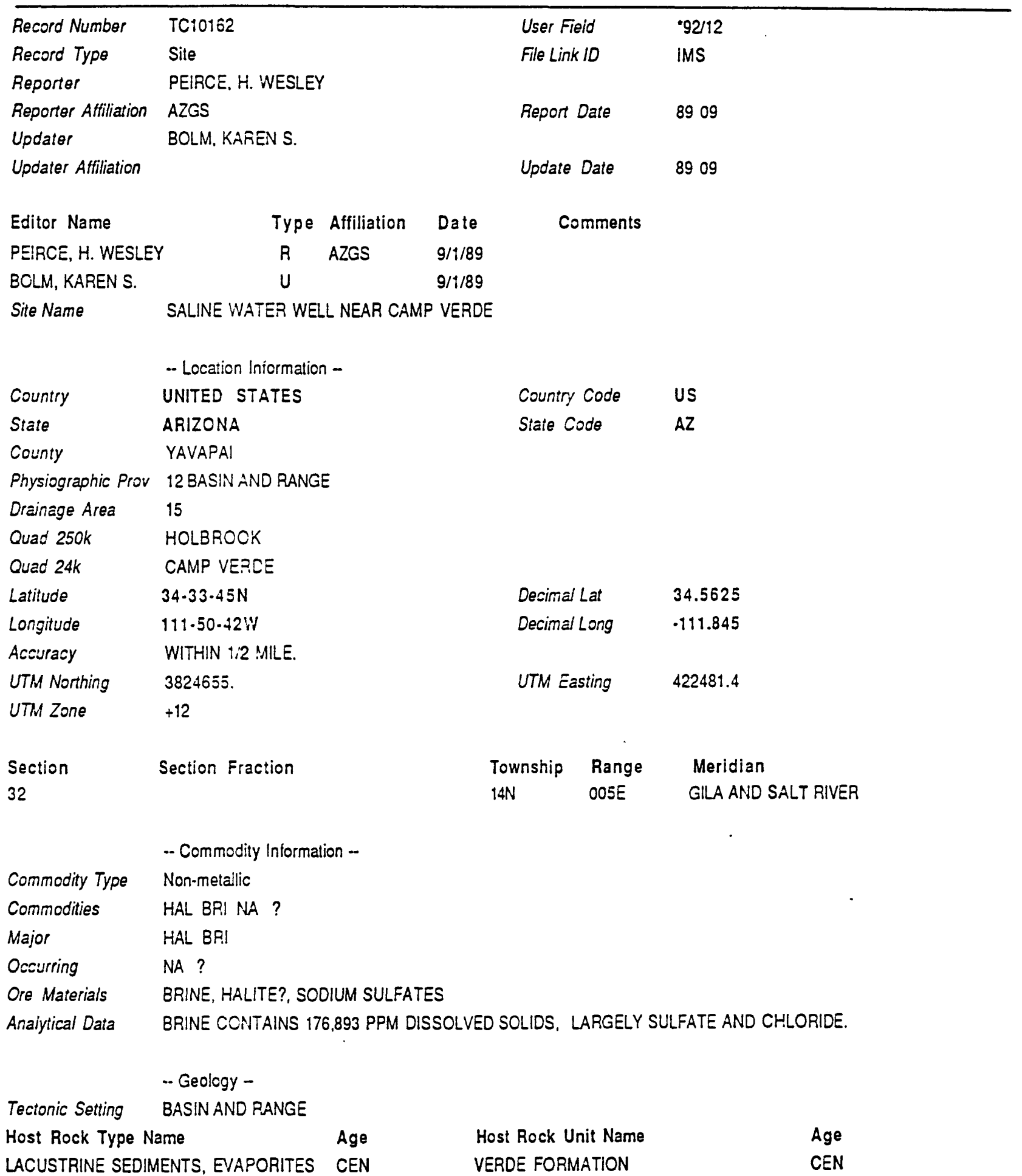

Page 1 


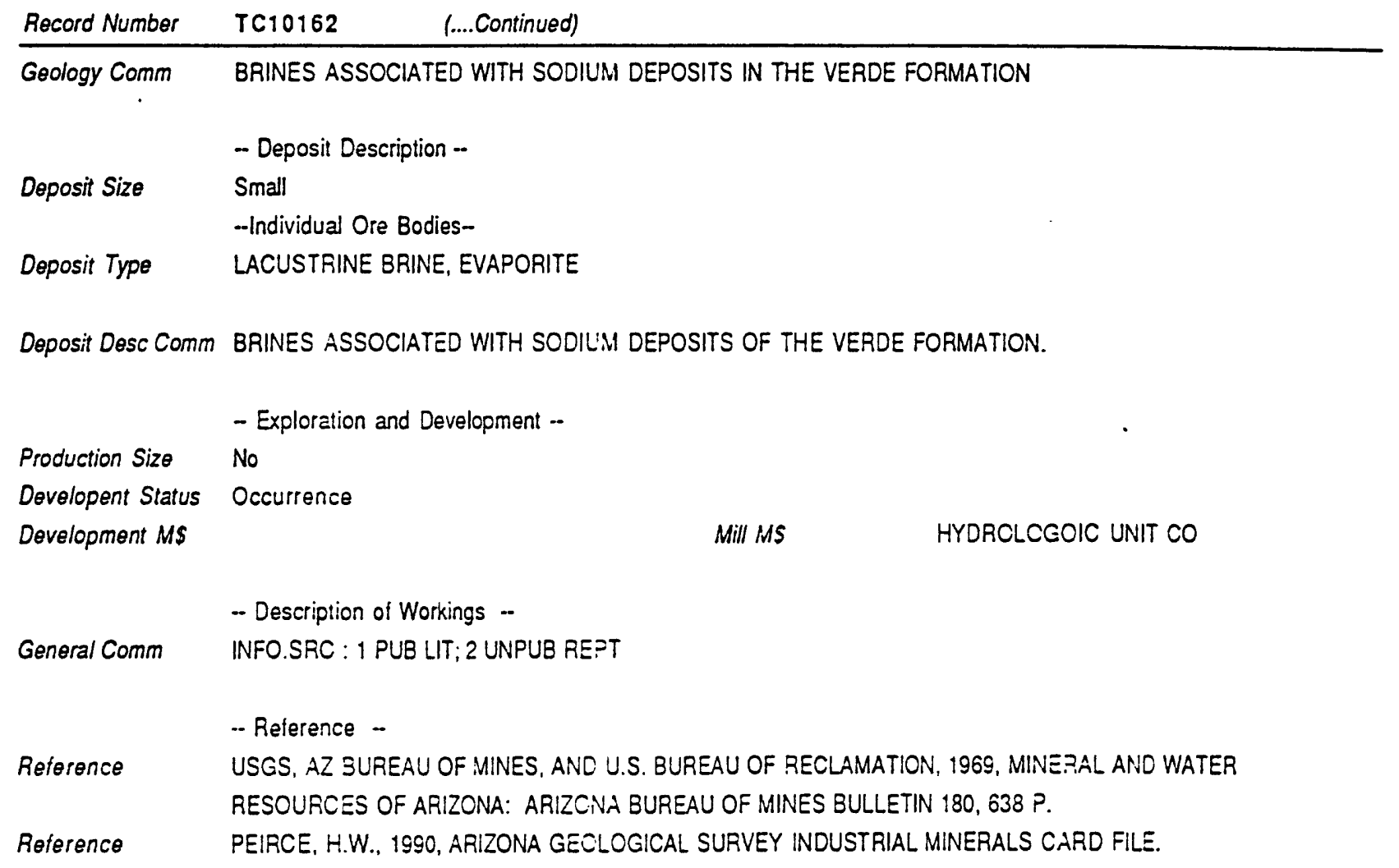

Page 2 


\section{Mineral Resources Data System (MRDS)}

Report Title

Issue Date 00/00/00

Current Date Monday, April 7, 1997

Current Time 10:24:50

Number 12 of 103

Record Number

TC35380

User Fieid

Printed 12 of 103

Record Type

Site

Reporter

CARBCNAÑO. MARGUERITE M.

Reporter Affiliation

USGS

WHITE HCRSE HILLS

File Link 10

-93/02

Site Name

- Lecation information -

Country

UNITED STATES

Country Code

US

State

ARIZONA

State Code

$A Z$

County

YAVAPAI

Physiographic Prov

COLORACO PLATEAU

Administrative Area

COCONINO NATICNAL FOREST

Quad 250k

HOLBROCK

Ouad 100k

SEDONA

Quad 24k

WALKER MTN. (1SES)

Latitude

$34.32 .48 \mathrm{~N}$

Longitude

$111.41 .07 \mathrm{~W}$

Decimal Lat

34.54666

Accuracy

EST LOCATION, +1-0.5 MI

UTM Northing

3822789 .

UTM Zone

$+12$

Section

Section Fraction

Decimal Long

.111 .58527

2

Location Comments LAT-LONG !S FOR CENTER OF SEC. 2.

$\begin{array}{ll}\text { Commodity Type } & \text { - Commocity Intormation -- } \\ \text { Commodities } & \text { PUM } \\ \text { Major } & \text { PUM } \\ \text { Ore Materials } & \text { CINDER } \\ & \\ \text { Host Rock Type } & \text { - CINDER CCNE } \\ & \\ & \text {-- Deposit Description -- } \\ & \text {--Individual Ore Bodies-- } \\ \text { Deposit Type } & \text { CINDER CONE } \\ & \\ & \\ \text { Production Size } & \text {-- Exploraticn and Development -- }\end{array}$

Production Size U 
Developent Status Occurrence

- Description of Workings .-

- Reference -

Reference

PEIRCE, H.W., 1990, ARIZONA GECLOGICAL SURVEY INDUSTRIAL MINERAL FILES.

Reference ELEVATORSKI, E.A., 1978, ARIZONA INDUSTRIAL MINERALS, MINERAL REPORT NO. 2, ARIZONA DMR.

Page 2 


\section{Mineral Resources Data System (MRDS)}

Report Title

Issue Date 00/00/00

Number 13 of 103

Current Date Monday. April 7, 1997

Current Time 10:24:50

Printed 13 ol 103

\begin{tabular}{|c|c|}
\hline Record Number & TC35471 \\
\hline Record Type & Site \\
\hline Reporter & CARBONARO, MARGUER \\
\hline Reporter Affiliation & USGS \\
\hline \multirow[t]{2}{*}{ Site Name } & WHITE CASTLE \\
\hline & - Location Intormation .- \\
\hline Country & UNITED STATES \\
\hline State & ARIZONA \\
\hline County & YAVAPAI \\
\hline Physiographic Prov & COLORADO PLATEAU \\
\hline Administrative Area & PRESCOTT NATIONAL FO \\
\hline Quad 250k & HOLBROOK \\
\hline Quad 100k & PAYSON \\
\hline Quad 24k & TULE MESA (1967) \\
\hline Latitude & $34.16 .06 \mathrm{~N}$ \\
\hline Longitude & $111 \cdot 50-42 \mathrm{~W}$ \\
\hline Acouracy & EST \\
\hline UTM Northing & 3792036. \\
\hline UTM Zone & +12 \\
\hline \multirow[t]{2}{*}{$\begin{array}{l}\text { Section } \\
4,5,8,9,17\end{array}$} & Section Fraction \\
\hline & -- Commedity Intormation -- \\
\hline Commodity Type & Non-metallic \\
\hline Commodities & $M B L$ \\
\hline Major & MBL \\
\hline Ore Materials & MARBLE \\
\hline
\end{tabular}

Host Rock Type LIMESTONE

Hosi Rock Age DEV

Host Rock Type Name

Age

Country Code US

State Code

$A Z$

$\begin{array}{ll}\text { User Fieid } & \bullet 93 / 02 \\ \text { File Link ID } & \text { CIMRI }\end{array}$

Report Date $\quad 9301$

Decimal Lat $\quad 34.26833$

Decimal Long $\quad .111 .845$

UTM Easting 422209.5

$\begin{array}{lll}\text { Township } & \text { Range } & \text { Meridian } \\ \text { ION } & \text { O5E } & \text { GILA AND SALT RIVER }\end{array}$

Host Rock Unit Name Age

MARTIN LIMESTONE DEV

-. Deposit Description -

-- Exploration and Development -

Production Size Yes

Developent Status Little Developed Producer, Inactive

Page 1 
- Descripticn of Workings --

- Relerence -

Reference PEIRCE, H.WV., 1990, ARIZONA GEOLOGICAL SURVEY INDUSTRIAL MINERAL FILES.

Prod Comments PAST PRODUCER.

Page 2 


\section{Mineral Resources Data System (MRDS)}

Report Title

Issue Date 00/00/00

Current Date Monday, April 7, 1997

Current Time 10:24:50

Number 14 of 103

Printed 14 of 103

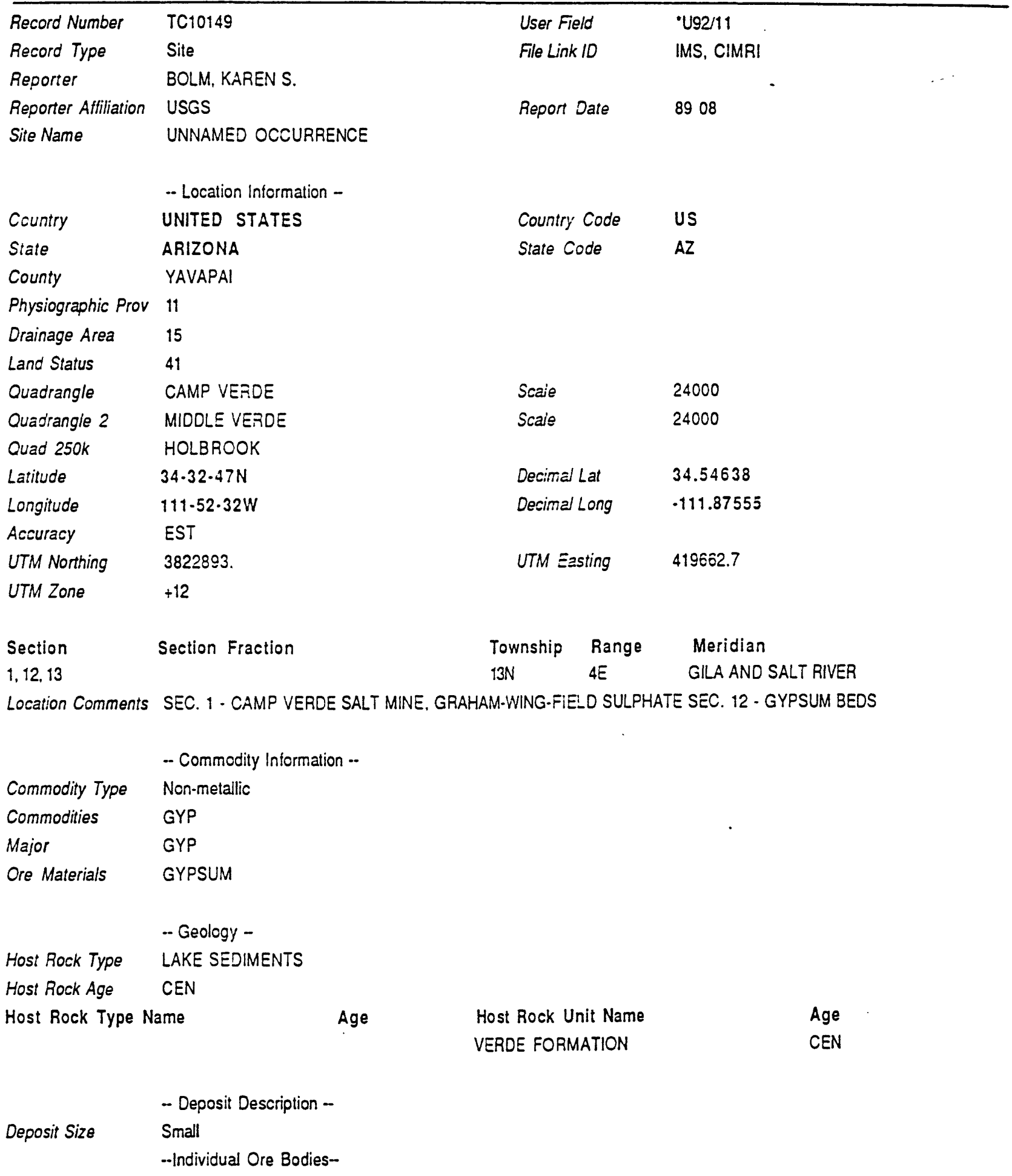




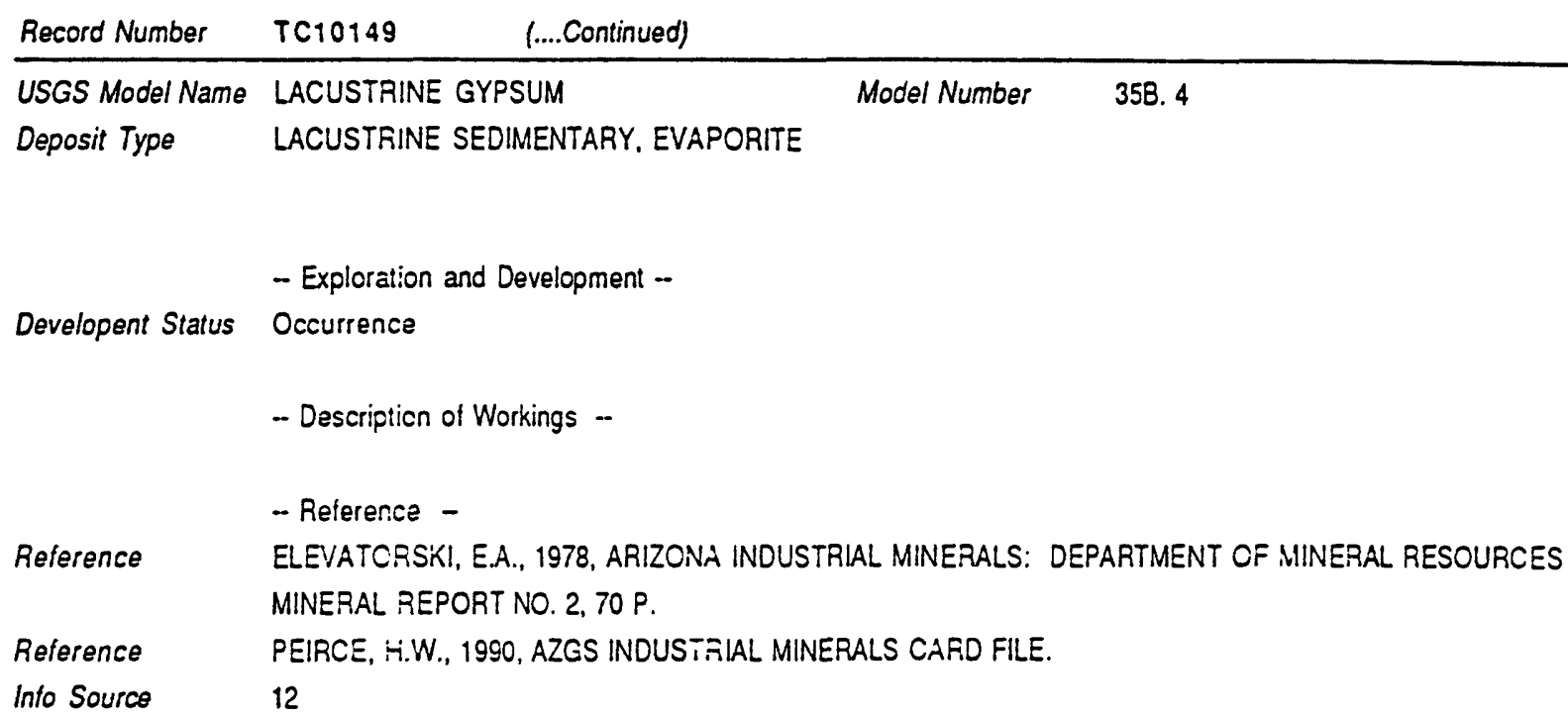

Page 2 


\section{Mineral Resources Data System (MRDS)}

Report Title

Issue Date 00/00/00

Current Date Monday, April 7, 1997

Current Time 10:24:50

Number 15 of 103

\section{Record Number}

Record Typo

Reporter

Reporter Affiliation

Site Name

TC10151

Site

BOLM, KAREN S.

USGS

WINGFIE!D-MCLEDD DEPOSIT

-. Location Information -

Country

$$
\text { UNITED STATES }
$$

State

ARIZONA

County

YAVAPAI

Physiographic Prov 11

Drainage Area $\quad 15$

Ouadrangle

CAMP VERDE

Ouad 250k

Latitude

Longitude

Accuracy

UTM Northing

HOLBROOK

UTM Zone

$34 \cdot 30-30 \mathrm{~N}$

$111 \cdot 48 \cdot 12 \mathrm{~W}$

WITHIN 1,2 MILE

3818618.

$+12$

Section

Section Fraction

22

$\begin{array}{ll} & \text {-. Commodity Intormation -- } \\ \text { Commodity Type } & \text { Non-metallic } \\ \text { Commodities } & \text { GYP } \\ \text { Major } & \text { GYP } \\ \text { Ore Materials } & \text { GYPSUM } \\ & \\ & \text {.. Geology - } \\ \text { Host Rock Age } & \text { CEN }\end{array}$

Age

\section{User Field}

File Link 10

Report Date

Country Code

State Code

US

$A Z$

-U92/11

IMS

8908

Scalo

24000

Decimal Lat

34.50833

Decimal Long

.111 .80333

UTM Easting

426256.1

$\begin{array}{lll}\text { Township } & \text { Range } & \text { Meridian } \\ 13 N & 5 E & \text { GILA AND SALT RIVER }\end{array}$

Printed 15 of 103

Host Rock Type Name

Host Rock Unit Name

Age

VERDE FORMATION

CEN

$\begin{array}{llll} & \text {-- Deposit Description -- } & & \\ \text { Deposit Size } & \text { Small } & & \\ & \text {--Individual Ore Bodies-- } & \text { Model Number } & 35 B .4 \\ \text { USGS Model Name } & \text { LACUSTRINE GYPSUM } \\ \text { Deposit Type } & \text { LACUSTRINE SEDIMENTARY, EVAPORITE } & & \end{array}$

Page 1 
- Exploration and Development -.

Production Size Yes

Developent Status Developed Producer, Inactive

Economic Comments PAST PRODUCTION FOR AGRICULTURAL USE

-. Description of Workings -

-- Reierence -

Reference ELEVATORSKI, EA., 1978, ARIZONA INDUSTRIAL MINERALS: DEPARTMENT OF MINERAL RESOURCES MINERAL REPORT NO. 2, 70 P.

Reterence PIERCE, H.W., 1990, AZGS INDUSTRIAL MINERALS CARD FILE.

Info Source 12

Page 2 


\section{Mineral Resources Data System (MRDS)}

Report Title

Issue Date 00/00/00

Current Date Monday, April 7. 1997

Current Time 10:24:50

Number 16 of 103

Printed 16 of 103

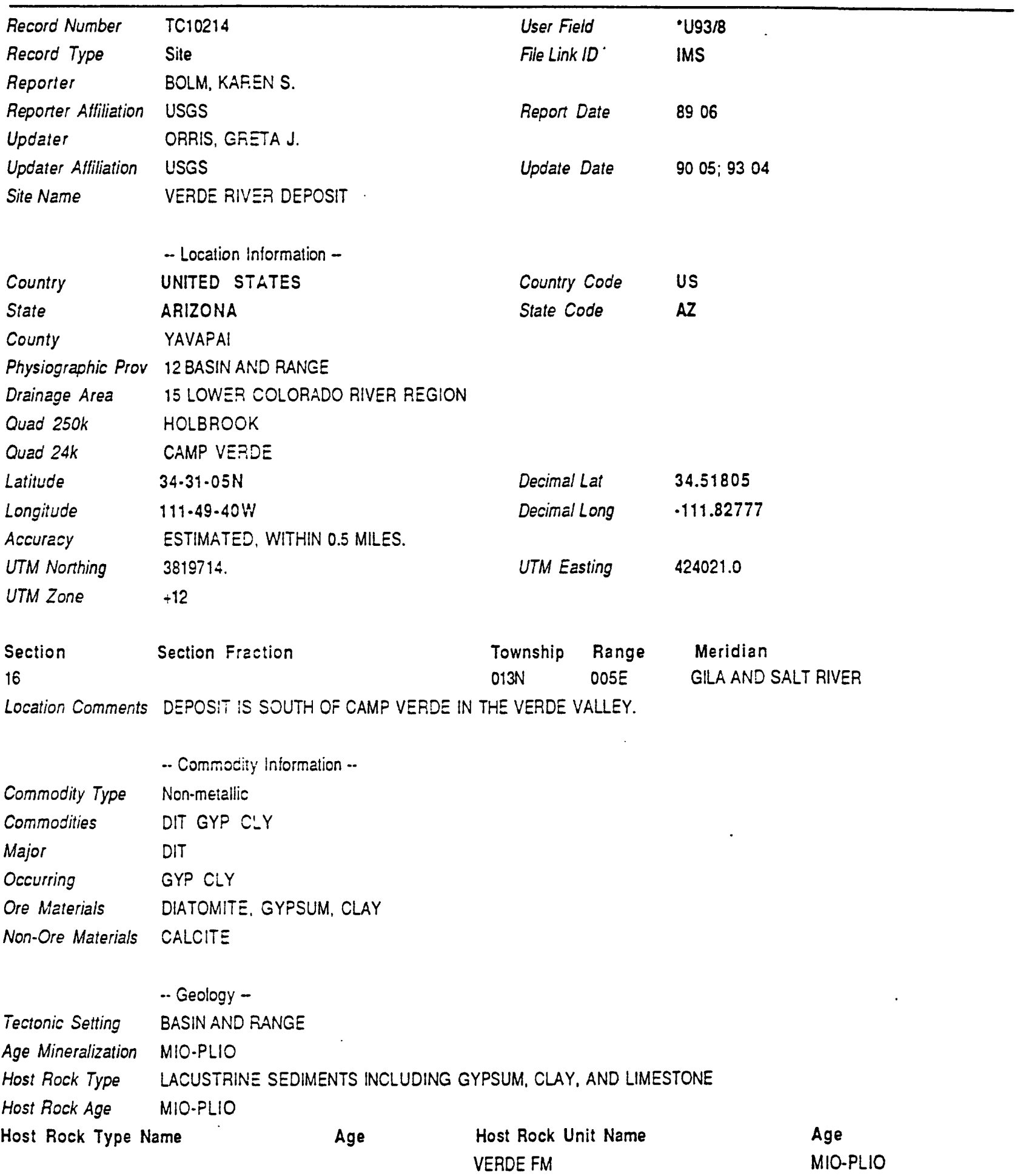

Page 1 
- Deposit Description -.

-Individuai Cre Sodies-

USGS Model Name

LACUSTFine DIATOMITE

Deposit Type LACUSTRINE BIOGENIC, SEDIMENTARY

Depth to Top 0

Model Number

315

Units

FI

Deposit Desc Comm DIATOMITE IS INTEABEDDED WITH GYPSUM, CLAY, AND LIMESTONE.

-. Explora:ien and Development ..

Proouction Size

No

Developent Status Prospect, inactive

-. Descrip:ion si Workings ..

Reierence

-. Refererce -

Reference PE!RCE, $-\because \% ., 1989$. ARIZONA GECLOGICAL SURVEY INDUSTRIAL MINERALS CARD FILES.

PHILLIPS. K.A., 1987, ARIZONA INDUSTRIAL MINERALS: ARIZONA DEPARTMENT OF MINES AND MINEFAL RESOUECES :.INERAL REPORT $\div,: 85$ P.

Reierence PEIRCE, -:.N. 1969, DIATOMITE, IN IIINERAL AND WATER RESOURCES OF AFIZCNA: WASHINGTCN. U.S. GOVERN:SENT PRINTING OFFICE, P. 337-342.

Info Source 1 


\section{Mineral Resources Data System (MRDS)}

Report Title

Issue Date 00100/00

Current Date Monday, April 7, 1997

Current Time 10:24:50

Number 17 of 103

Printed 17 of 103

Record Number

TC35321

User Field

Record Type

Reporter

Reporter Affiliation

Site Name

Site

WELLS, TINA M.

USGS

VOLUNTEER MOUNTAIN

- Location Iniormation -

Country

State

County

Administrative Area

Quad 250k

Quad 24k

Latitude

Longitude

Accuracy

UTM Northing

UTM Zone

Section

$5,0,7,8$

Location Comments

UNITED STATES

ARIZONA

COCONINO

NAVAJO AFIIY DEPOT/KAIBAB NATIONAL FOREST

FLAGSTAFF

BELLEMONT

$35 \cdot 13.52 \mathrm{~N}$

$111-53-10 \mathrm{~W}$

$A C C+1-1 \mathrm{NIN}$

3898834 .

File Link 10

-U93/6

IMS, CIMRI

Report Date

9210

$+12$

Section Fraction

Township

Range

$021 \mathrm{~N}$

OOSE

Counity Code

US

State Code

$A Z$

LOCATION IS FOR CENTER OF SECTION 5.

$\begin{array}{ll}\text { Decimal Lat } & 35.23111 \\ \text { Decimal Long } & -111.88611 \\ \text { UTM Easting } & 419365.9\end{array}$

- Commodity Intormation --

Commodity Type

Commodities

Non-metallic

Major

VOL

VOL

Ore Materials

CINDERS

- Geology -

Host Rock Type

CINDER CONE

-. Deposit Description -.

Deposit Size

Small

--Individual Ore Bodies-

Deposit Type VOLCANIC

-. Exploration and Development --

Production Size

No

Developent Status

Occurrence 


$\begin{array}{ll}\text { Desc Workings } & \begin{array}{l}\text { - Description of Workings -- } \\ \text { Surface }\end{array} \\ & \text { - Reierence - } \\ \text { Reference } & \text { ELEVATCRSKI, E.A., 1978, ARIZONA INDUSTRIAL MINERALS, MINERAL REPORT NO. 2, ARIZCNA CIVIR. } \\ \text { Reference } & \text { PEIRCE. H.W., 1990, ARIZONA GECLOGICAL SURVEY INDUSTRIAL MINERAL FILES. } \\ \text { Reference } & \text { PHILLIPS. K.A., 1987, ARIZONA INDUSTRIAL MINERALS: ARIZONA DEPARTMENT OF MINES AND MINESNIL } \\ & \text { RESOURCES MINERAL REPORT 4, } 185 \text { P. }\end{array}$

Page 2 


\section{Mineral Resources Data System (MRDS)}

Report Title

Issue Date 00/00/00

Current Date Monday, April i, 1997

Current Time 10:24:50

Number 18 of 103

Printed 18 of 103

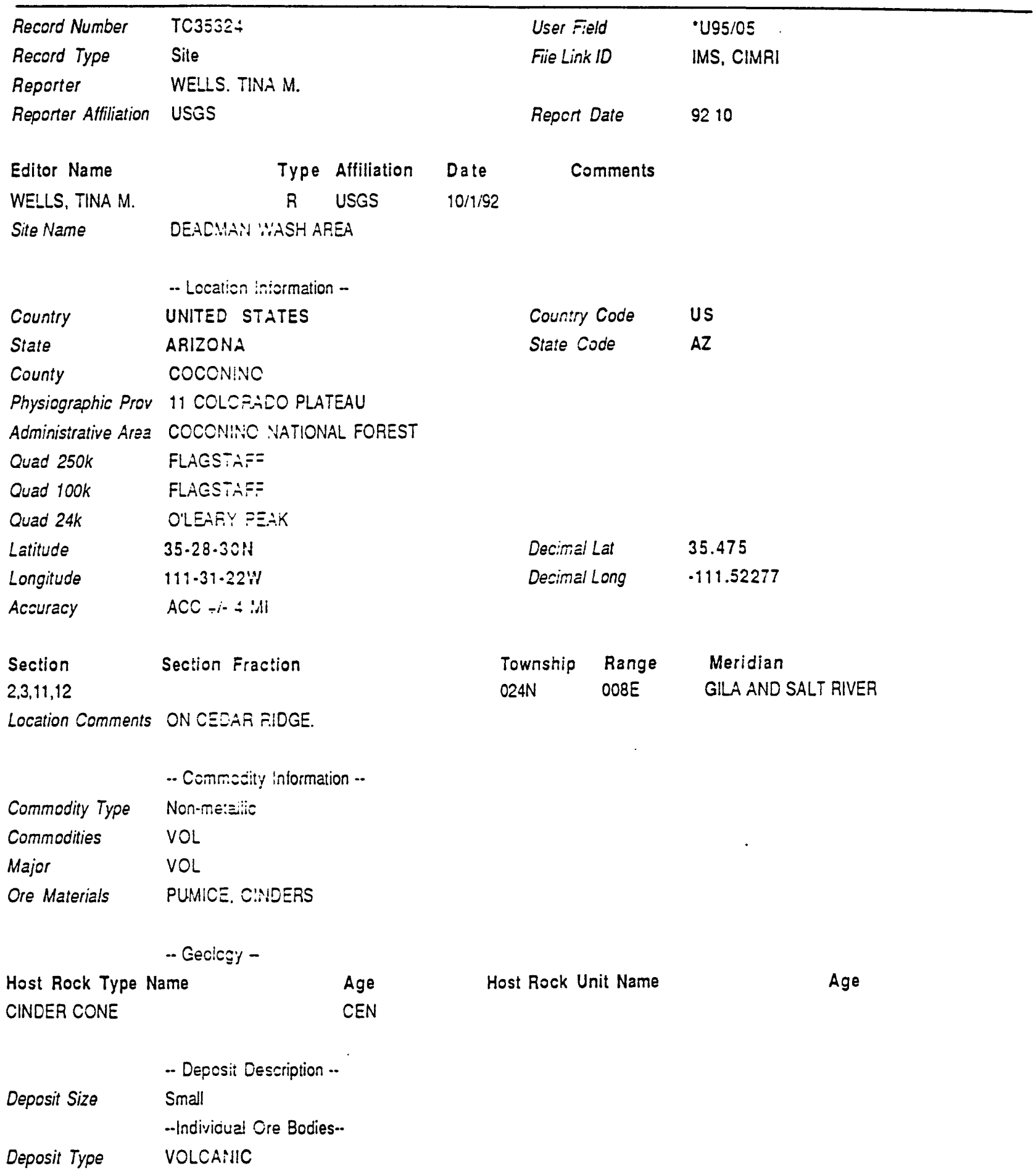


-- Exploration and Development --

Production Size

Developent Status

Development MS
Yes

Developed Producer, Inactive

Mill MS

- Description of Workings -

Dese Workings

Surface

- Reference -

Reference ELEVATORS'́l, E.A., 1978, ARIZCNA INCUSTRIAL MINEFALS, MINERAL REFORT NO. 2, ARIZONA DMR.

Reference PEIRCE, H.W., 1990, ARIZONA GECLOGICAL SURVE! :NDUSTRIAL MINERAL FILES.

$P \leqq \Xi \sqsupseteq 2$ 


\section{Mineral Resources Data System (MRDS)}

Report Title

Issue Date 00/00/00

Current Date Monday, April 7, 1997

Current Time 10:24:50

Number 19 of 103

Printed 19 of 103

Record Number
Record Type
Reporter
Reporter Affiliation
Site Name

TC35325

User Field

-U93/6

Site

File Link 10

IMS, CIMRI

WELLS. TINA M.

USGS

Report Date

9210

CEDAR RIDGE

- Location intormation --

Country

UNITED STATES

Country Code

US

State

ARIZONA

State Code

AZ

County

COCONINO

Physiographic Prov

11 COLORADO PLATEAU

Quad 250k

FLAGSTAFF

Quad 100k

FLAGSTAFF

Quad $24 k$

OLEARY PEAK

Latitude

$35 \cdot 28 \cdot 42 \mathrm{~N}$

Decimal Lat

35.47833

Longitude

$111.32 \cdot 30 \mathrm{~W}$

Decimal Long

.111 .54166

Accuracy

$\mathrm{ACC} \div 2 \mathrm{MI}$

UTM Northing

3926026.

UTM Zone

$+12$

Section Section Fraction

9.10

Township

Range

Meridian

$024 \mathrm{~N}$

OOBE

GILA AND SÁLT RIVER

-. Commodity intormation ..

Commodity Type

Non-metallic

Commodities VOL

Major VOL

Ore Materials CINDERS

Commod Comments CINDERS ARE RED IN COLOR.

Host Rock Type CINDER CONE

-- Deposit Description --

Deposit Size Small

-.Individual Ore Bodies--

Deposit Type VOLCANIC

-. Exploration and Development -

Production Size

$$
\text { U }
$$


Record Number

TC35325

Prospect, Inactive

- Description of Workings --

Desc Workings Suriace

- Reference -

Reference

Reference

PHILLIPS, K.A., 1987, ARIZONA INDUSTRIAL MINERALS: ARIZONA DEPARTMENT OF MINES AND MINEFAL RESOURCES MINERAL REPORT 4, 185 P.

PEIRCE. H.Y., 1990, ARIZONA GECLOGICAL SURVEY INDUSTRIAL MINERAL CARD FILES.

Page 2 


\section{Mineral Resources Data System (MRDS)}

Report Title

Issue Date 00/00/00

Current Date Monday, April ? 1997

Current Time 10:24:50

Number 20 of 103

Printed 20 of 103

\begin{tabular}{|c|c|c|c|c|c|}
\hline Record Number & 1001090 & & & User Field & 'U95/05 \\
\hline Record Type & Site & & & File ! ink 10 & IMS, CIMR \\
\hline Reporter & ORRIS. GFEEA J. & & & & \\
\hline Reporter Affiliation & USGS & & & Report Date & 9110 \\
\hline Editor Name & Type & Affiliation & Date & Comments & \\
\hline ORRIS, GRETA J. & R & USGS & $00 / 00: 00$ & & \\
\hline ORRIS, GRETA J. & $u$ & USGS & $5 / 1 / 95$ & & \\
\hline Site Name & \multicolumn{5}{|c|}{ CAMP VE:EE GYPSUM } \\
\hline 10 Comments & \multicolumn{5}{|c|}{ POSSIBLY QUPLICATE IN PART OR WHOLLY WITH LARSON QUARRY. } \\
\hline
\end{tabular}

-- Location information -

\begin{tabular}{|c|c|c|c|}
\hline Country & UNITED STATES & Couniry Code & US \\
\hline State & ARIZONA & Staie Code & $A Z$ \\
\hline County & YAVAPAI & & \\
\hline Quad 250k & HOLBRCCK & & \\
\hline Quad 24k & WALKER IITN. (?) & & \\
\hline Latitude & $34.33 .42 \mathrm{~N}$ & Decima/ Lat & 34.56160 \\
\hline Longitude & $111.44 .50 \%$ & Decimal Long & $\cdot 111.74722$ \\
\hline Accuracy & ESTIMATE= LOC & ? MINUTES. & \\
\hline
\end{tabular}

$\begin{array}{llll}\text { Section Section Fraction } & \text { Township } & \text { Range } & \text { Merician } \\ & 014 N & \text { OO6E } & \text { GILA AND SALLT RIVER }\end{array}$

Position 5.5 MILES ミ OF CAMP VERDE ON STATE HIGHWAY 260.

- Commocivy Intormation --

Commodity Type Non-meta!:

Commodities GYP

Major GYP

Ore Materials GYPSUM

Commod Subtypes SUPPLIES GYFSUM TO PHOENIX CEMENT COMPANY PLANT AT CLARKDALE. ALSO USED FOR AGRICULTUAE, IMPERVIOUS SEALLING USES.

Age Mineralization CEN

- Geology -

Host Rock Type Name

LACUSTRINE SEDIMENTS

Age

CEN

- Deposit Cescription --

-individual Ore Bodies-

Deposit Type

LACUSTRINE SEDIMENTARY, EVAPORITE
Host Rock Unit Name

VERDE FM
Age

CEN 


$\begin{array}{ll} & \text { - Exploraticn and Development - } \\ \text { Production Size } & \text { Small } \\ \text { Developent Status } & \text { Develcped Producer, Active } \\ \text { Owner } & \text { SUPERICF COMPANIES (1994) } \\ \text { Operator } & \text { SUPERICA COMPANIES (1994) } \\ \text { Development MS } & \end{array}$

-- Description of Workings --

Desc Workings Surtace

Reference

$$
\text { -- Relerers: - }
$$

KE!TH, S.E.. 1969, GYPSUM, IN U.S. GEOLOGICAL SUAVEY, ARIZONA BUREAU OF MINES, AND U.S. BL:AEAU OF RECL:i.IATION, MINERAL ANO WATER RESOUFCES OF ARIZONA: ARIZONA BUREAU OF MINES BULLETN : $: 0.638$ ?.

Reference ARIZONA Z EPARTMENT OF MINES AND MINERAL FESOURCES, 1994, DIRECTORY OF ACTIVE MINES N ARIZONA, NCORPORATING SANO \& GRAVE: OPEAATIONS - 1994: ARIZONA DEPARTMENT MINES AND MINERAL IESOURCES DIRECTC:YY $42,24 \mathrm{P}$.

$$
P=\Xi 22
$$




\section{Mineral Resources Data System (MRDS)}

Report Title

Issue Date 00/00/00

Current Date Monday, Asril $i, 1997$

Current Time 10:24:50

Number 21 of 103

Record Number

TC35E50

User Field

File Lirk 10

"U94/11

Record Type

Sile

Reporter

ORRIS. BREIA J.

Reporter Affiliation

USES

Repori Date $\quad 9303$

Editor Name

ORRIS, GRETA J.

ORRIS, GRETA J.

Site Name

Synonym Name

$\begin{array}{cll}\text { Type } & \text { Affiliation } & \text { Date } \\ R & \text { USGS } & 3 / 1 / 93 \\ U & \text { USES } & 9 / 19 / 94\end{array}$

Comments

Printed 21 of 103

CAMP VEF:ES SALT MINE

GRAHAA:S WINGFIELD SULPHATE

-. Locatisn iniormation --

Country

UNITED STATES

State

ARIZONA

Country Code

US

County

YAVAFAI

Administrative Area

PRESCOTI NATIONAL FOREST

Quad 250k

HOLEFOOK

Quad 100k

SECONA

Quad 24k

CAMP VESEE (1969)

Latitude

$34 \cdot 32 \cdot 42 \mathrm{~N}$

Decimal Lat

34.545

Longitude

$111.52 .25 \mathrm{~W}$

Decimal Long

.111 .87388

Section

Section Fraction

01

Position

ABCUT $: .:$ WI SW OF CAMP VEFOE.

Township Range

Meridian

$013 \mathrm{~N}$

DO4E

GILA AND SALT RIVER

-. Commocity Information --

Commodity Type

Non-meiallic

Commodities

HAL NA ? GYP CLY

Major

HAL NA ?

Occurring

GYP CLY

Ore Materials

HALITE, THENARDITE, MIRABILITE, GLAUBERITE, GYPSUM, CLAY

Commod Subtypes

SALT FCR CATTLE FEED.

-. Geolegy -

Regional Trends VERDE FALLT ZONE

Age Mineralization MIO?

Host Rock Type Name

Age

Host Rock Unit Name

Age

LACUSTRINE SEDIMENTS, EVAFORITES MIO?

VERDE FM

CEN

Geology Comm THE VE:PCE FM CONSISTS OF AT LEAST $1600 \mathrm{FT}$ OF SEDIMENTS THAT ACCUMULATED IN A BASIN FORMEJ DURING THE OLIGOCENE. POSSIELY AS A RESULT OF MOVEMENT ALONG THE VERDE FAULT

Page 1 


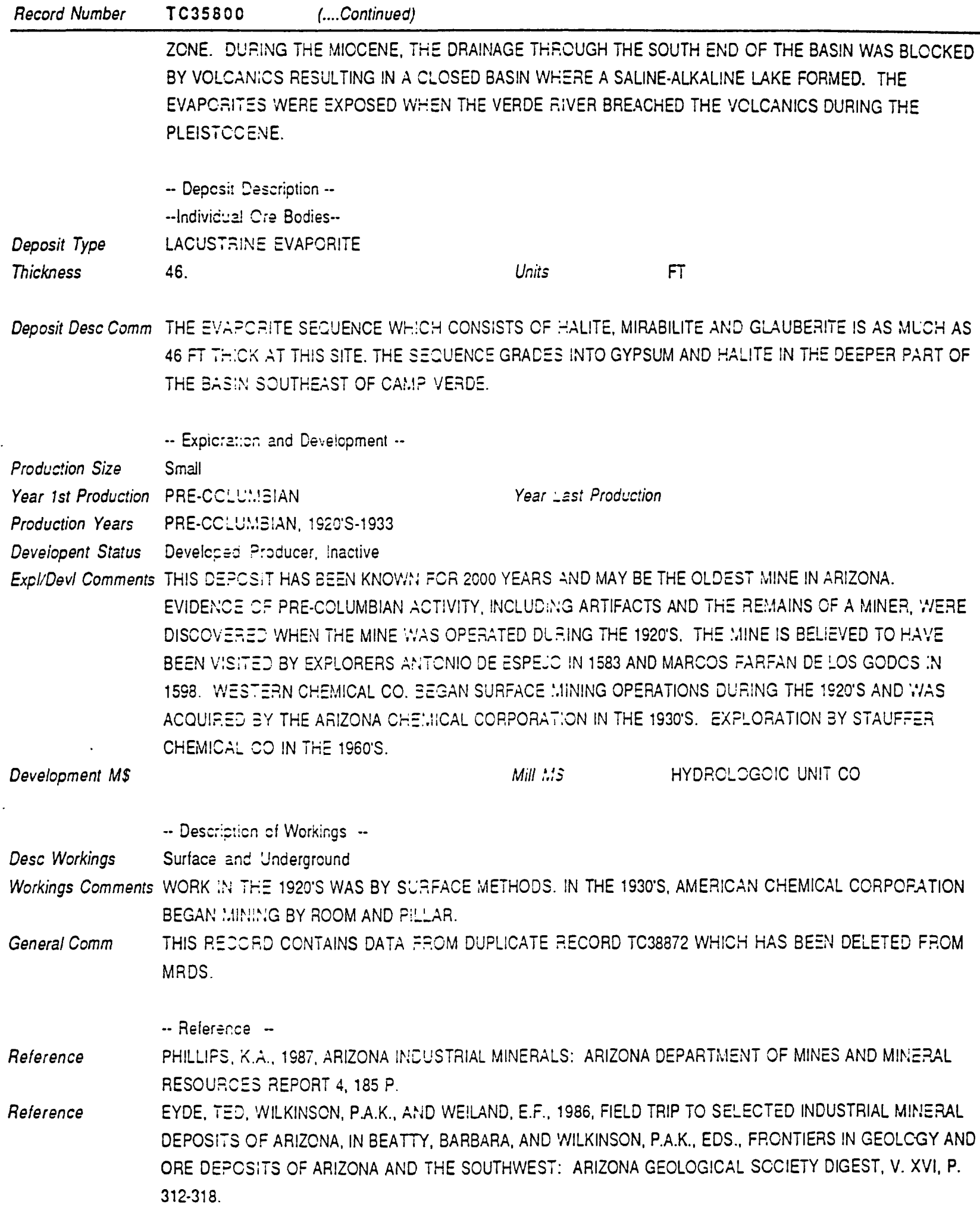




\section{Mineral Resources Data System (MRDS)}

Report Title

Issue Date 00/00100

Current Date Monday, April 7, 1997

Number 22 of 103

Record Number

TC10262

Record Type

Site

File Link 10

-U93/11

Reporter

CAREONAFO, MARGUERITE

Reporter Affiliation

USGS

ORRIS, GRETA J.

Updater

USGS

Updater Affiliation

CLARKDALE CLAY QUARRY

Site Name

LAKEBED

Synonym Name

-. Location Iniormation --

\begin{tabular}{|c|c|c|c|}
\hline Country & UNITED STATES & \multicolumn{2}{|c|}{ Counity Code } \\
\hline State & ARIZONA & \multicolumn{2}{|c|}{ State Code } \\
\hline County & YAVAPAI & & \\
\hline Ouad 250k & PRESCOTT & & \\
\hline Quad $62.5 k$ & CLARKDALE & & \\
\hline Latitude & $34 \cdot 46 \cdot 10 \mathrm{~N}$ & \multicolumn{2}{|c|}{ Decmal Lat } \\
\hline Longitude & $112 \cdot 06 \cdot 30 \mathrm{~W}$ & \multicolumn{2}{|c|}{ Deciri:al Long } \\
\hline Accuracy & EST & & \\
\hline UTM Northing & 3847838 & \multicolumn{2}{|c|}{ UTiv Easting } \\
\hline UTM Zone & +12 & & \\
\hline Section & Section Fraction & Township & Range \\
\hline 18 & & $016 \mathrm{~N}$ & OO3E \\
\hline \multirow[t]{2}{*}{ Position } & NORTH OF CLARKDALE, AZ. & & \\
\hline & -. Commodity Intormation .. & & \\
\hline Commodity Type & Non-metalic & & \\
\hline Commodities & CLY7 SHL & & \\
\hline Major & CLY7 SHL & & \\
\hline Ore Materials & CLAY SHALE & & \\
\hline Commod Subtypes & CLAY USED IN PORTLAND C & BRIC & STION. \\
\hline
\end{tabular}

-. Geology -

Host Rock Type SHALE

Host Rock Age CEN

Host Rock Type Name

SHALE

CEN

VERDE FORMATION

US

$A Z$

Printed 22 of 103

Report Date $\quad 9109$

Upda:e Date 9304

MS, CMRI

109

34.76944

.112 .10833

398575.3

Meridian

GILA AND SALT RIVER

-. Deposit Description --

-.Individual Ore Bodies--

Deposit Type SEDIMENTARY 
Deposit Form BEDDED

- Exploraticn and Development -.

Production Size Yes

Developent Status Developed Producer, Active

Operator PHOENIX CEIIENT CO.

-. Description of Workings --

Desc Workings Surface

-- Refererise --

Reference

PATTEFSC.V. S.H., 1969, "CLAY", N ABM BULLETIN i EO, USGS BULLETIN 87i, P. 332.

Reference PEIRCE, H.V., 1990, ARIZONA GEZ_OGICAL SURVEY INDUSTRIAL MINERALS CARD FILE.

Reference PHILLIPS, $\nvdash \therefore ., 1987$, ARIZONA IN $=$ STRIAL MINERÄ:S: ARIZONA DEPARTMENT OF MINES AND MINERAL RESOURCES MINERAL REPORT $\div$. : 95 P.

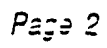




\section{Mineral Resources Data System (MRDS)}

Report Title

Issue Date 00100/00

Current Date Monday, April 7. 1997

Number 23 of 103

Record Number TC38868

Record Type Site

Reporter

ORRIS, GFETA G.

Reporter Affiliation USGS

Site Name MCCARTHY CLAY

-. Location Iniormation -

Country

UNITED STATES

State

ARIZONA

Quad 250k

HOLBROOK

Latitude

$34 \cdot 43 \cdot 30 \mathrm{~N}$

Longitude

$111.58 .55 \mathrm{~W}$

UTM Northing

3842789 .

UTM Zone

$+12$

Section

Section Fraction

Current Time 10:24:50

Printed 23 of 103

\section{User Field}

File Link 10

Report Date

$\begin{array}{ll}\begin{array}{ll}\text { Country Code } \\ \text { State Coce }\end{array} & \text { US } \\ & \text { AZ } \\ \text { Decimal Lat } & 34.725 \\ \text { Decimal Long } & -111.98194 \\ \text { UTM Easting } & 410093.5\end{array}$

Township Range

Meridian

GILA AND SALT RIVER
Commodity Type

Commodities

Major

Production Size

Developent Status

U

-. Commodity Information -.

Non-metallic

CLY

CLY

-. Geology ..

-- Deposit Description --

- Exploration and Deveiopment --

Occurrence

-- Description of Workings .-

-- Reference - 


\section{Mineral Resources Data System (MRDS)}

Report Title

Issue Date 00/00100

Current Date Monday, Aprit :, $₫ \$ \$ 7$

Current Time 10:24:50

Number 24 of 103

Printed 24 of 103

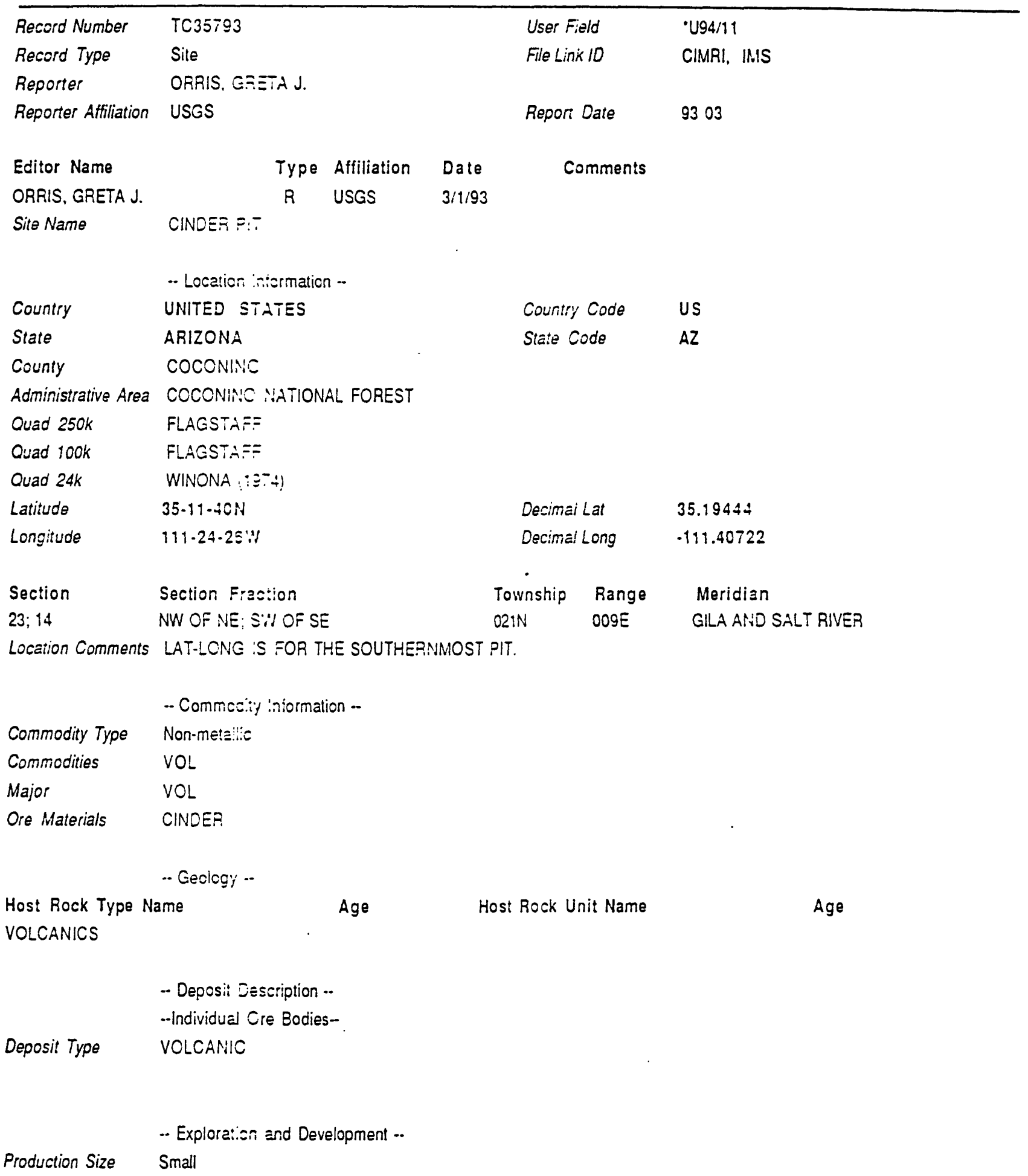




\begin{tabular}{|c|c|}
\hline Record Number & (....Continued) \\
\hline \multirow{3}{*}{$\begin{array}{l}\text { Developent Status } \\
\text { Development MS }\end{array}$} & Little Developed Producer, Inactive \\
\hline & HYDROLOGOIC UNIT CO \\
\hline & - Description of Workings - \\
\hline Desc Workings & Surface \\
\hline General Comm & $\begin{array}{l}\text { THIS RECORD CONTAINS DATA FAOM DUPLICATE RECORD TC } 35784 \text { WHICH HAS BEEN DELETEU FROM } \\
\text { MRDS. }\end{array}$ \\
\hline & - Reference .- \\
\hline Reference & WINONA 7.5 MINUTE TOPOGRAFHIC QUADRANGLE. \\
\hline Reference & $\begin{array}{l}\text { PHILLIPS, K.A., 1987, ARIZONA INDUSTRIAL MINERALS: ARIZONA DEPARTMENT OF MINES AND MINERAL } \\
\text { RESOURCES MINERAL REPORT } 4,185 \mathrm{P} \text {. }\end{array}$ \\
\hline Reference & PEIRCE, H.W., 1990, ARIZONA GECLOGICAL SURVEY INDUSTRIAL MINERALS CARD FILES. \\
\hline
\end{tabular}

Pą? 2 


\section{Mineral Resources Data System (MRDS)}

Report Title

Issue Date 00100100

Current Date Monday, April T, 1997

Current Time 10:24:50

Number 25 of 103

Record Number TC35416

Record Type Site

User Field U94/11

Reporter

ORRIS, GRETA J.

Reporter Affiliation USGS

File Linik $10 \quad$ CIMRI, IMS

Report Date

9210

Editor Name

ORRIS, GRETA J.

Site Name

Type Affiliation Date

Comments

WILECAT HILL PIT

-- Location Intormation -

Country

UNITED STATES

Country Code

US

State

ARIZONA

State Cooe

AZ

County

COCONINO

Physiographic Prov

Land Status

41

Administrative Area

Quad 250k

COCONINO NATIONAL FOREST

Quad 100k

FLAGSTAF:

Quad 24k

FLAGSTAFF

Latitude

FLAGSTAFF EAST

Longitude

$35 \cdot 13 \cdot 19 \mathrm{~N}$

Decimal Lat

35.22194

Accuracy

$111 \cdot 32 \cdot 52 W$

Decimai Long

.111 .54777

Section

$\mathrm{ACC}$

9,4

Section Fraction

Township Range

Meridian

Location Comments

PEIRCE GIVES LOCATION AS SECTION 7.

$021 \mathrm{~N}$

OOBE

GILA AND SALT RIVER

-. Commedity Information .-

Commodity Type Non-metallic

Commodities VOL STN1

Major VOL STN1

Ore Materials VOLCANIC CINDER

Commod Subtypes USED FOR AGGREGATE

-. Geology -

- Deposit Description --

--Individual Ore Bodies-

Deposit Type

VOLCANIC

Printed 25 of 103 


\begin{tabular}{|c|c|}
\hline Record Number & (.....Continued) \\
\hline & \\
\hline Production Size & Yes \\
\hline Developent Status & Developed Producer, Active \\
\hline Owner & FLAGSTAFF CINDER SALES INC. \\
\hline Development MS & HYDROLCGOIC UNIT CO \\
\hline & - Description of Workings .- \\
\hline Desc Workings & Surface \\
\hline General Comm & $\begin{array}{l}\text { THIS RECORD CONTAINS DATA FROM DUPLICATE RECORD TC } 35323 \text { WHICH HAS BEEN DELETED FROM } \\
\text { MRDS. }\end{array}$ \\
\hline & - Reierence - \\
\hline Reference & $\begin{array}{l}\text { ARIZONA DEPARTMENT OF MINES AND MINERAL RESOURCES, } 1989 \text {, DIRECTCRY OF ACTIVE MINES IN } \\
\text { ARIZONA, INCORPORATING SAND AND GRAVEL OFERATIONS-1989-1990: ARIZCNA DEPARTMENT OF } \\
\text { MINES AND MINERAL RESOURCES DIRECTORY, } 14 \text { P. }\end{array}$ \\
\hline Reference & PEIRCE, H.W., 1990, ARIZONA GEOLOGICAL SURVEY INDUSTRIAL MINERALS CARD FILE. \\
\hline Reference & $\begin{array}{l}\text { PHILLIPS, K.A., 1987, ARIZONA INDUSTRIAL MINERALS: ARIZONA DEPARTMENT OF MINES AND MINE:AL } \\
\text { RESOURCES MINERAL REPORT 4, } 185 \text { P. }\end{array}$ \\
\hline
\end{tabular}

Page 2 


\section{Mineral Resources Data System (MRDS)}

Report Title

Issue Date 00/00/00

Current Date Monday. Acril i. 1997

Current Time 10:24:50

Number 26 of 103

Printed 25 of 103

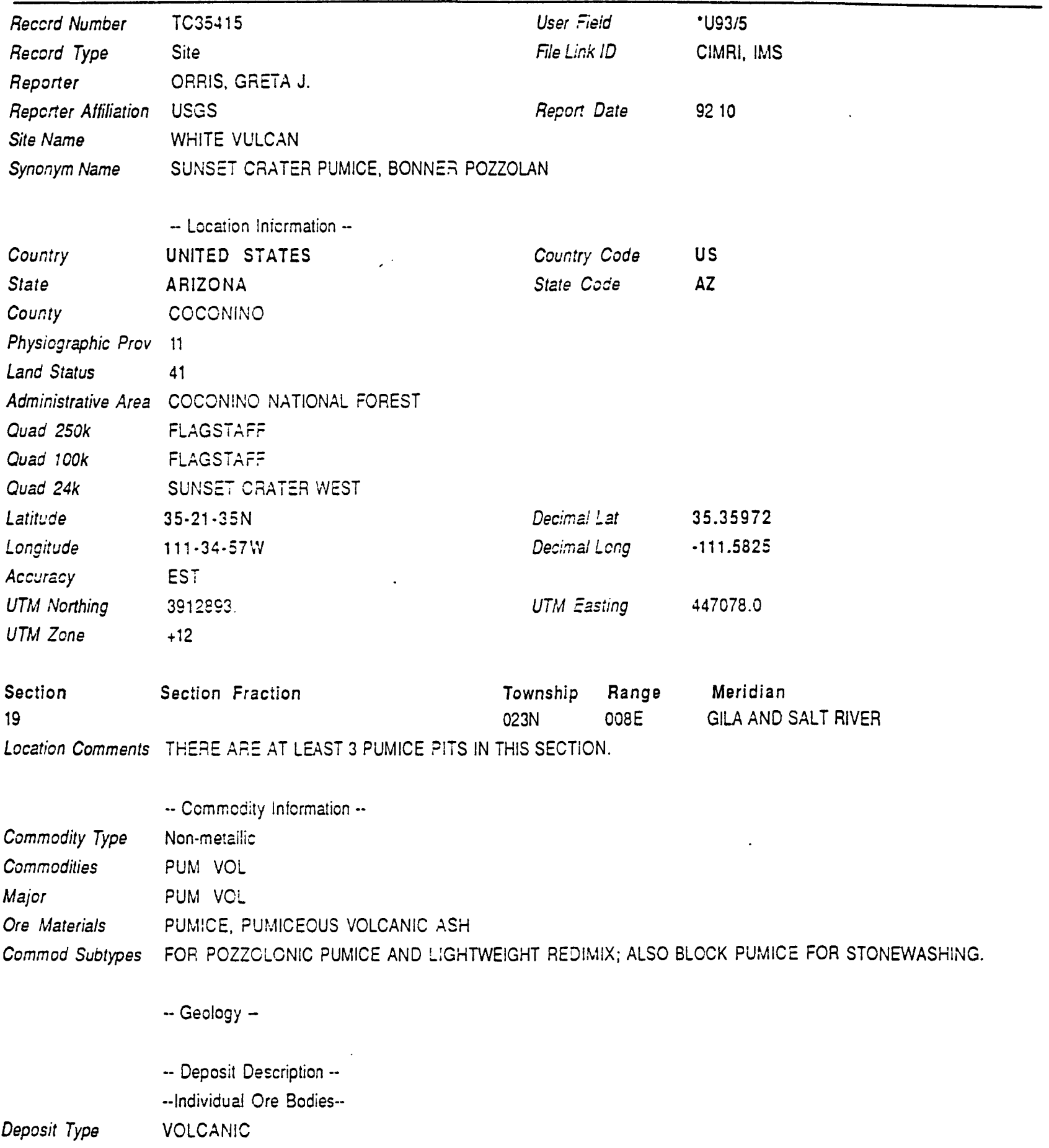


- Exploration and Development -.

Production Size Yes

Developent Status Intermiltent Producer

Owner ARIZONA TUFFLITE INC.

- Description of Workings --

Dese Workings Surface

Reference

- Reference -

ARIZONA DEPARTMENT OF MINES AND MINERAL RESOURCES, 1989, DIRECTORY OF ACTIVE MINES IN ARIZONA, INCORPORATING SAND AND GRAVEL ORERATIONS-1989-1990: ARIZONA DEPARTMENT OF MINES AND MINEEAL RESOURCES DIRECTORY, $14 P$.

Reference PHILLIPS, K.A., 1987, ARIZONA INCUSTRIAL MINEFALS: ARIZONA DEPARTMENT OF MINES AND MINERAL RESOURCES MINERAL REPORT $4,185 \mathrm{P}$.

Page 2 


\section{Mineral Resources Data System (MRDS)}

Report Title

Issue Date 00/00/00

Current Date Monday, April ?, 1997

Current Time 10:24:50

Number 27 of 103

Printed 27 of 103

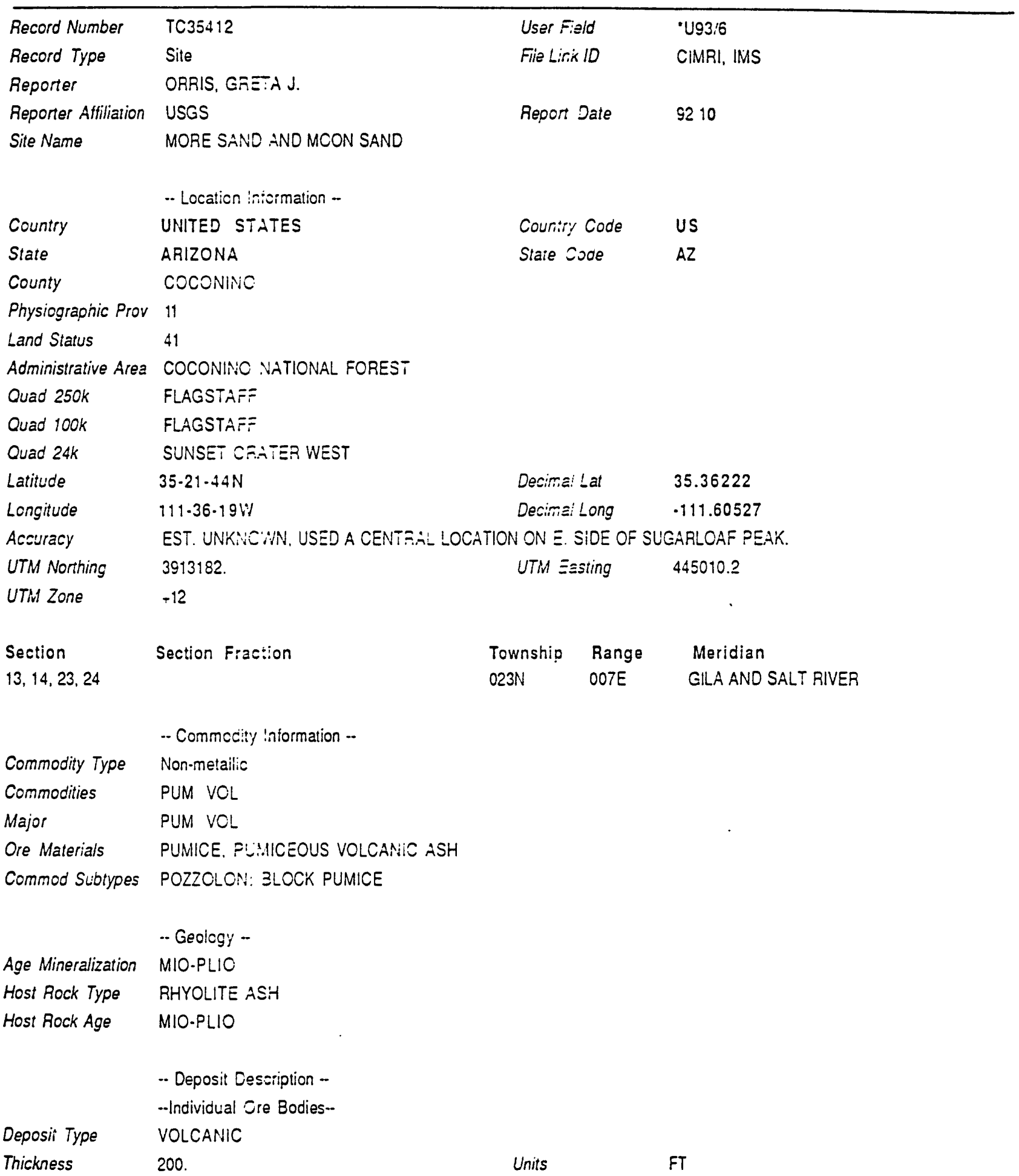


Deposit Desc Comm PUMICE FRAGMENTS ARE COARSE TO FINE, ANGULAR TO ROUNDED, BEDDED OR UNSORTED, AND LOOSELY CCNSOLIDATED. THE DEPOSITS ARE UP TO 200 FT THICK.

- Exploration and Cevelopment .-

Production Size Yes

Developent Status Intermittent Producer

Owner ARIZONA TUFFLITE CO.

- Description of Workings --

Desc Workings Surface

-. Reierence --

Reference ARIZONA DEPARTIAENT OF MINES AND MINERAL RESOURCES, 1989, DIRECTORY OF ACTIVE MINES IN ARIZONA, INCORPCA.ATING SAND AND GRAVEL OPERATIONS-1989-1990: ARIZONA DEPARTMENT OF MINES AND MINESALL RESCURCES DIF:ECTORY, $14 P$.

Reference PHILLIPS, K.A., 1987, ARIZONA INCUSTRIAL MINERALS: ARIZONA DEPARTMENT OF MINES AND MINEPAL RESOURCES MINEPAL REPORT 4, $185 \mathrm{P}$.

Reference PEIFCE, H.W., 199O. ARIZONA GEZLOGICAL SURVEY INDUSTRIAL MINERALS CARD FILE. 


\section{Mineral Resources Data System (MRDS)}

Report Title

Issue Date 00/00/00

Current Date Monday, Aprii 7, 1997

Current Time 10:24:50

Number 28 ol 103

Printed 28 of 103

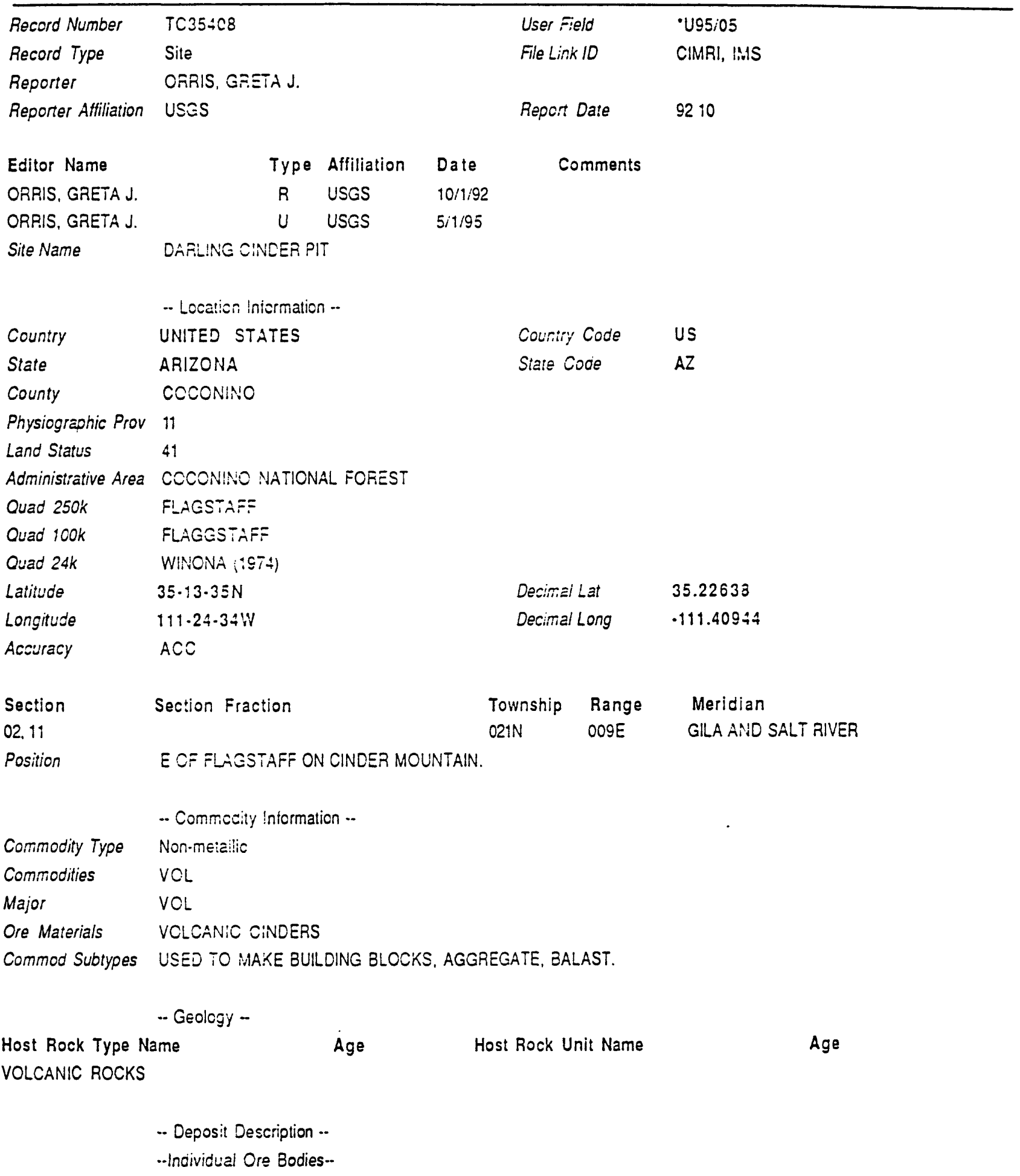




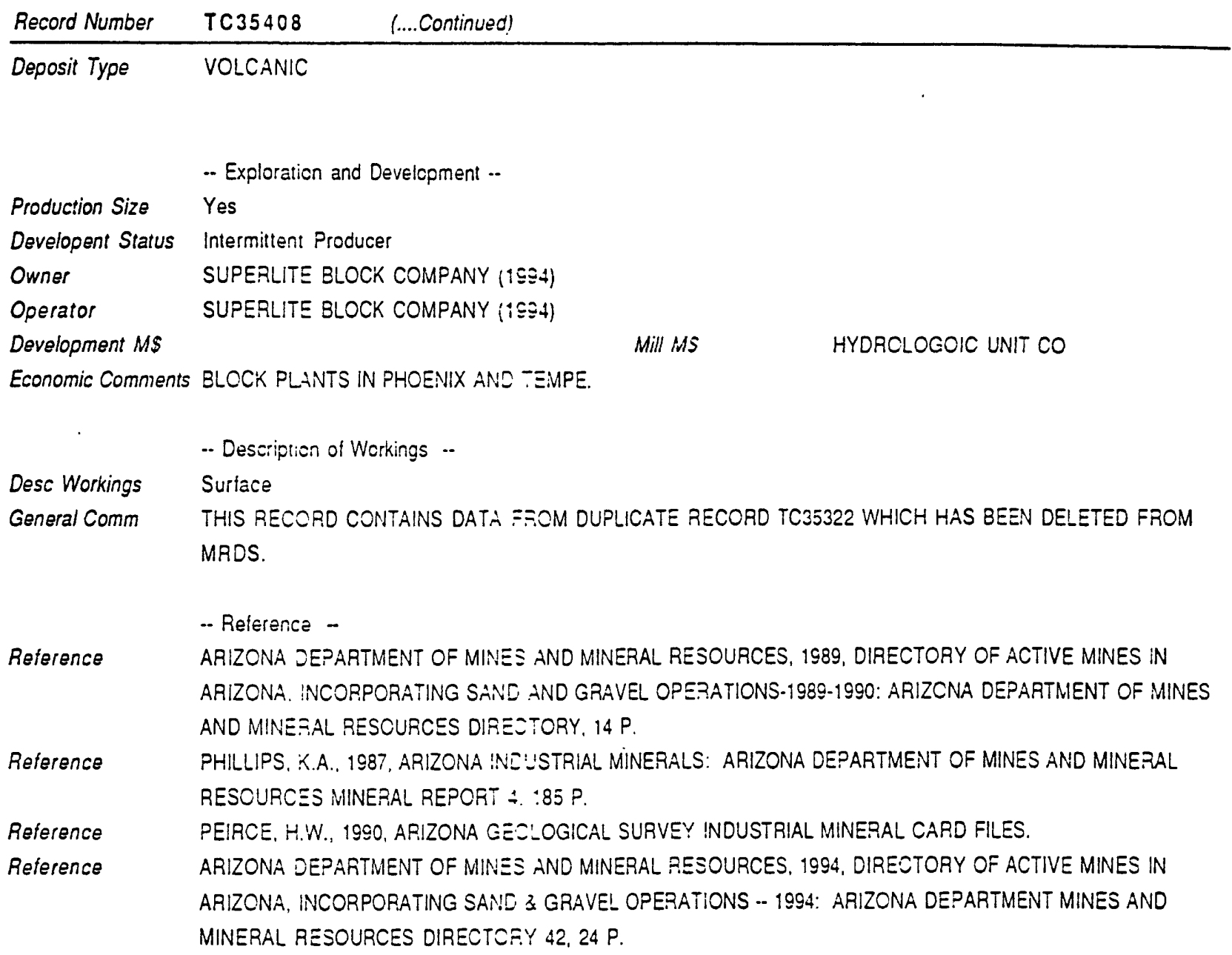

$P \cong \Xi \cong 2$ 


\section{Mineral Resources Data System (MRDS)}

Report Title

Issue Date 00/00/00

Current Date Monday, Açril $\bar{i}, 1997$

Current Time i0:24:50

Number 29 of 103

Printed 29 of 103

Record Number
Record Type
Reporter
Reporter Affiliation
Site Name

TC35 $\div 07$

User $F_{i=1: 0}$

U95/05

Site

File Lirin :D

CIMRI, IMS

ORRIS, GFETA J.

USGS

Repor Sate

9210

CROWN CLAINS

- Location information --

Country

UNITED STATES

Couniry Code

US

State

ARIZONA

State $C=z e$

AZ

County

COCONINO

Physiographic Prov 11

Land Status $\quad 41$

Adminisirative Area CCCONINO NATIONAL FOREST

Ouad 250k

FLAGSTAFF

Quad 100k

FLAGSTAF:

Quad 24k

O'LEARY ?EAK (1983)

Latitude

$35 \cdot 23 \cdot 53 \mathrm{~N}$

Longitude

$111-35-33 \mathrm{~W}$

Decima: '-at

35.39944

Aceuracy

EST, MAY ¿E O MILES OFF.

Decrma: : sng

.111 .60915

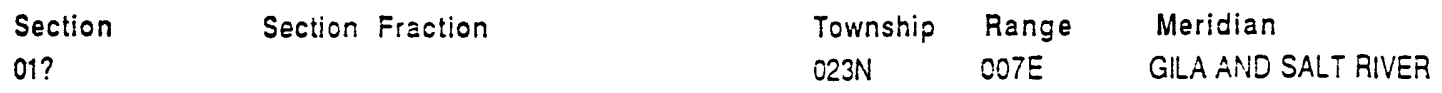

Position ABOUT 12 IALLS NOF FLAGSTAFF.

- Commedity Information .-

Commodity Type Non-metallic

Commodities PUM

Major PUM

Ore Materials PUMICE

Commod Subtypes POZZCLAI:IC PUMICE FOR LIGHT'HEIGHT REDIMIX; ELCCK MATERIAL FOR "STONE WASHING".

-. Geciogy -

Host Rock Type Name

Age

Host Rock Unit Name

Age

VOLCANICS, PUMICE

-- Deposit Description .-

--Individual Ore Bodies--

Deposit Type VOLCANIC

-. Exploraticn and Development ..

Page 1 


\begin{tabular}{|c|c|}
\hline Record Number & (.....Continued) \\
\hline Production Size & Yes \\
\hline Developent Status & Intermittent Producer \\
\hline Owner & TUFFLITE INC. (1994) \\
\hline Operator & TUFFLITE INC. (1994) \\
\hline Development MS & HYDROLCGOIC UNIT CO \\
\hline \multirow[t]{2}{*}{ Economic Comments } & MARKETED WITHIN AND OUTSICE OF ARIZCNA. \\
\hline & - Description of Workings .- \\
\hline \multirow[t]{2}{*}{ Desc Workings } & Surface \\
\hline & - Reierense - \\
\hline \multirow[t]{3}{*}{ Reference } & ARIZONA IEPAARTMENT OF MINES AND MINERAL RESOURCES, 1989, DIRECTORY OF ACTIVE MINES IN \\
\hline & ARIZONA, :NCORPORATING SANO AND GRAVEL OPERATIONS-1989-1990: ARIZCNA DEPARTMENT OF MINES \\
\hline & AND MINEF:AL RESOURCES DIREOTORY, $14 \mathrm{P}$. \\
\hline \multirow[t]{2}{*}{ Reference } & ARIZONA DEPARTMENT OF MINES AND MINERAL RESOURCES, 1994, DIRECTORY OF ACTIVE MINES IN \\
\hline & $\begin{array}{l}\text { ARIZCNA, NNCORPORATING SAND \& GRAVEL OPERATIONS - 1994: ARIZONA DEPARTMENT MINES AND } \\
\text { MINERAL FESOURCES DIRECTCRY } 42,24 \mathrm{P} \text {. }\end{array}$ \\
\hline
\end{tabular}

Pag 2 


\section{Mineral Resources Data System (MRDS)}

Report Title

Issue Date 00/00/00

Current Date Monday, April T, 1997

Current Time 10:24:50

Number 30 of 103

Printed 30 of 103

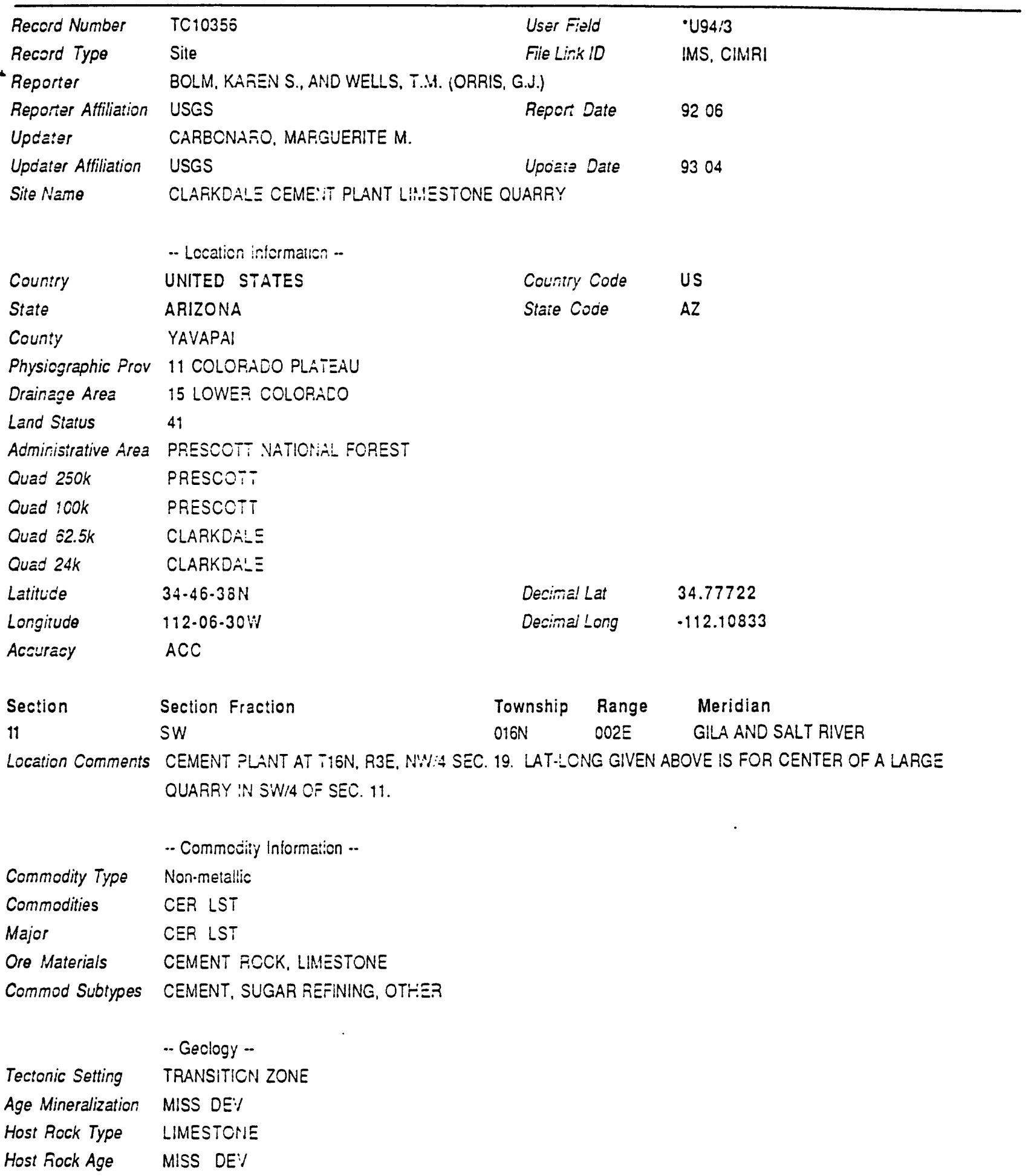




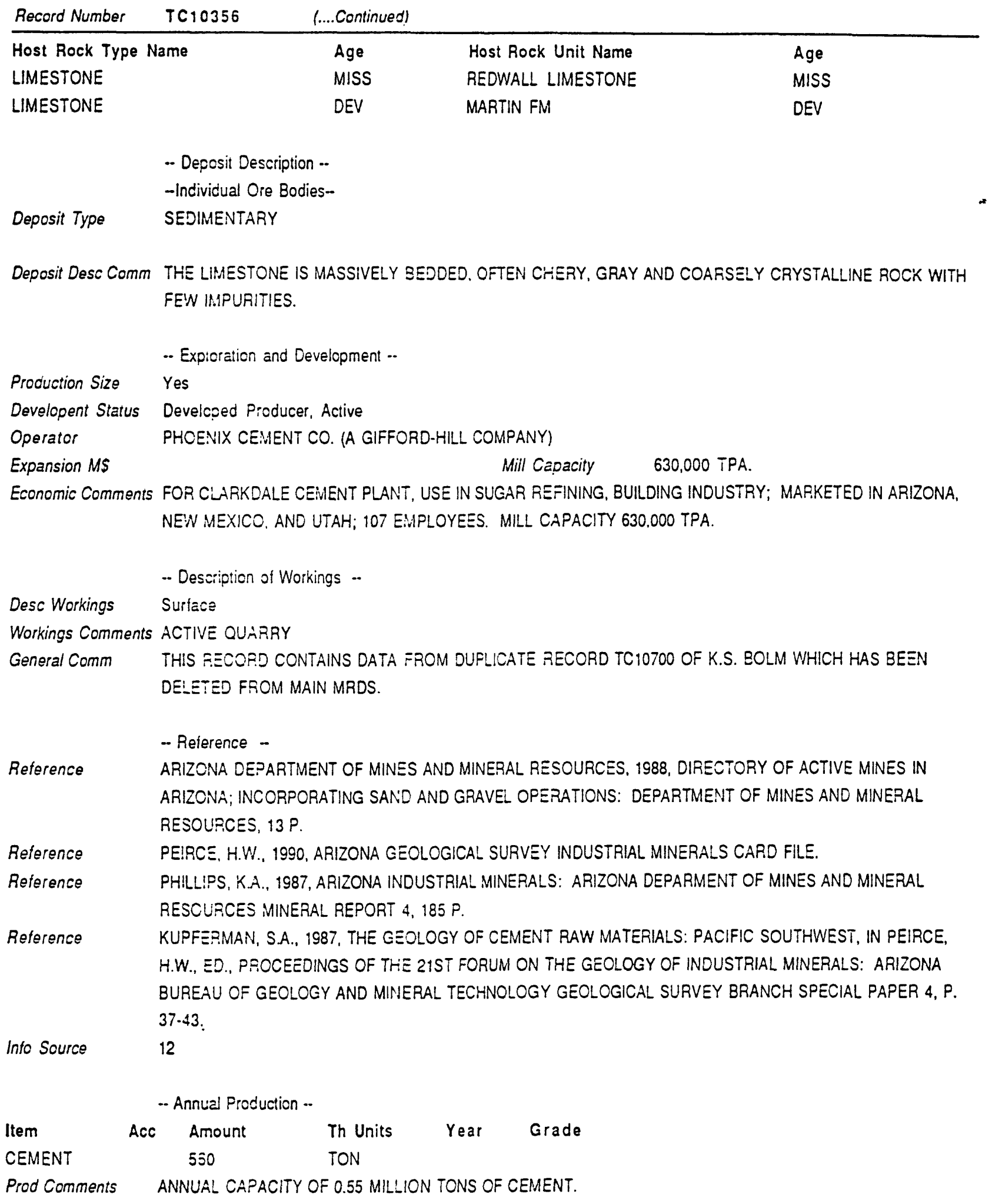




\section{Mineral Resources Data System (MRDS)}

Report Title

Issue Date 00100100

Current Date Monday, April $\bar{z}, 1997$

Current Time 10:24:50

Number 31 of 103

Printed 31 of 103

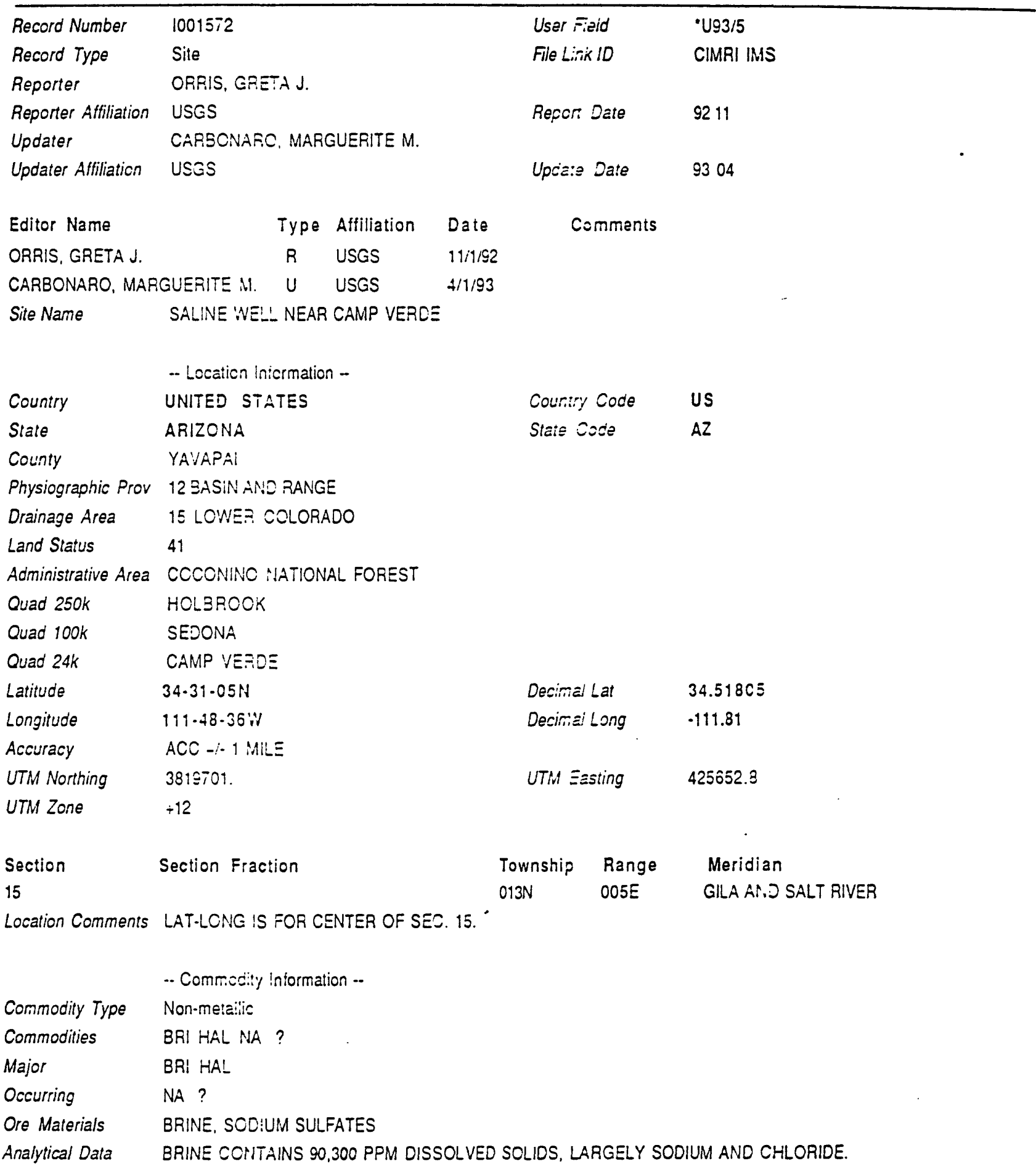


-- Geology --

Tectonic Setting BASIN AND RANGE

Host Rock Type Name Age

Age Host Rock Unit Name

LACUSTRINE SEDIMENTS, EVAPORITES CEN

VERDE FM

- Deposit Description --

Deposit Size Small

--Individual Ore Bodies-

Deposit Type LACUSTRINE SRINE, EVAPORITE

Deposit Desc COmm SOCIUM CHLORIDE BRINES ASSCCIATED WITH SCDIUM SLLFATE DEPOSITS CF THE VERDE FM.

- Exploration and Development --

Production Size

No

Developent Status Occurrence

Development M\$

Mill MS

HYDROLOGCIC UNIT CO

-. Description of Workings ..

-- Relerence .-

Reference USGS, ARIZCNA BUREAU OF MINES. AND U.S. BUFEAU OF RECLAMATION, 1SOQ, MINERAL AND WATER RESOURCES OF ARIZONA: ARIZONA BUREAU OF MINES BULLETIN 180, 638 ?.

Reference PEIRCE, H.W., 1990, ARIZONA GEOLOGICAL SURVEY INDUSTRIAL MINERALS CAFD FILE.

Page 2 


\section{Mineral Resources Data System (MRDS)}

Report Title

Issue Date 00/00/00

Number 32 of 103

Current Date Monday, April T. 1997

Current Time 10:24:50

Printed 32 of 103

\begin{tabular}{|c|c|c|c|c|}
\hline Record Number & TC38480 & \multicolumn{2}{|c|}{ User Fieid } & •93/6 \\
\hline Record Type & Site & \multicolumn{2}{|c|}{ File Link ID } & CIMRI, IMS \\
\hline Reporter & ORRIS, GRE:IA J. & & & \\
\hline Reporter Affiliation & USGS & \multicolumn{2}{|c|}{ Report Cate } & 9304 \\
\hline Site Name & $\begin{array}{l}\text { WRIGHT HILL CINDER PIT } \\
\text {-- Lccation intormation - }\end{array}$ & & & \\
\hline Country & UNITED STATES & \multicolumn{2}{|c|}{ Country Code } & US \\
\hline State & ARIZONA & \multicolumn{2}{|c|}{ State Cocie } & $A Z$ \\
\hline County & COCONINO & & & \\
\hline Physiographic Prov & 11 COLOFADO PLATEAU & & & \\
\hline Drainage Area & 15 LOWEA COLORADO & & & \\
\hline Land Status & 41 & & & \\
\hline Adminisirative Area & KAIBAB NÄ::ONAL FOREST & & & \\
\hline Quad 250k & FLAGSTAF= & & & \\
\hline Quad 100k & FLAGSTAF: & & & \\
\hline Quad 24k & PARKS (1950) & · & & \\
\hline Elevation & $7300 \mathrm{FT}$ & & & \\
\hline Latitude & $35.18 .09 N$ & Decimai & Lat & 35.3025 \\
\hline Longitude & $111-57 \cdot 18 \mathrm{~W}$ & Decimal & Long & .111 .955 \\
\hline Accuracy & $A C C$ & & & \\
\hline Section & Section Fraction & Township & Range & Meridian \\
\hline 10 & SW OF NE & $22 \mathrm{~N}$ & $004 E$ & GILA ANO SALT RIVER \\
\hline Position & ABOUT 3 :Al N OF PARKS. & & & \\
\hline \multirow[t]{2}{*}{ Location Comments } & PIT IS AT THE NE BASE OF WFIG HT HILL. & & & \\
\hline & -- Commecity Intormation -- & & & \\
\hline Commodity Type & Non-metallic & & & $\cdot$ \\
\hline Commodities & VOL & & & \\
\hline Major & VOL & & & \\
\hline \multirow[t]{4}{*}{ Ore Materials } & CINDER & & - & \\
\hline & .- Geology - & & & \\
\hline & -- Deposit Cescription -- & & & \\
\hline & --Individual Ore Bodies-- & & & \\
\hline Deposit Type & VOLCANIC & & & \\
\hline
\end{tabular}


Production Size Small

Developent Status Little Developed Producer, Inactive

$\begin{array}{ll}\text { Desc Workings } & \text { - Description of Workings -- } \\ & \text { Surface } \\ & \text {-- Reference - } \\ \text { Reference } & \text { PHILLIPS, K.A., 1987. ARIZONA INCUSTRIAL MINERALS: ARIZONA DEPARTMENT OF MINES AND MINEFAL } \\ & \text { RESOURCES REPORT 4, 185 P. } \\ \text { Reference } & \text { PEIRCE. H.W., 1990, ARIZONA GECLOGICAL SURVEY INDUSTRIAL MINERAL CAFD FILES. }\end{array}$

Page 2 


\section{Mineral Resources Data System (MRDS)}

Report Title

Issue Date 00100/00

Current Date Monday, April T, 1997

Current Time 10:24:50

Number 33 of 103

Printed 33 of 103

\begin{tabular}{|c|c|c|c|c|}
\hline Record Number & TC36496 & \multicolumn{2}{|c|}{ User Fieid } & $\cdot 93 / 6$ \\
\hline Record Type & Site & \multicolumn{2}{|c|}{ File Link 10} & CIMRI, IMS \\
\hline Reporter & ORRIS, GFETA J. & & & \\
\hline Reporter Affiliation & USGS & \multicolumn{2}{|c|}{ Report Date } & 9304 \\
\hline \multirow[t]{2}{*}{ Site Name } & NCRTH OF PARKS & & & \\
\hline & -. Lccation Iniormation -- & & & \\
\hline Country & UNITED STATES & \multicolumn{2}{|c|}{ Country Code } & US \\
\hline State & ARIZONA & \multirow{2}{*}{\multicolumn{2}{|c|}{ State Coze }} & $A Z$ \\
\hline County & COCONINO & & & \\
\hline Physiographic Prov & 11 COLORADO PLATEAU & & & \\
\hline Drainage Area & 15 LOWEA COLORADO & & & \\
\hline Land Status & 41 & & & \\
\hline Administrative Area & KAIBAE NATIONAL FOREST & & & \\
\hline Quad 250k & FLAGSTAFF & & & \\
\hline Quad $100 \mathrm{k}$ & FLAGSTAFF & & & \\
\hline Ouad 24k & PAFKS (1980) & & & \\
\hline Elevation & $7350 \mathrm{FT}$ & & & \\
\hline Latitude & $35.17 .05 N$ & Decimal & iat & 35.28472 \\
\hline Longitude & $111.57 .04 \mathrm{~W}$ & Decimal & Long & $\cdot 111.95111$ \\
\hline Accuracy & $A C C$ & & & \\
\hline Section & Section Fraction & Township & Range & Meridian \\
\hline 15 & SE OF SE & $22 \mathrm{~N}$ & $004 E$ & GILA AND SALT RIVER \\
\hline \multirow[t]{2}{*}{ Position } & 1.5 NH N CF PARKS. & & & \\
\hline & .- Commozity iniormation .. & & & \\
\hline Commodity Type & Non-metailic & & & \\
\hline Commodities & VOL & & & \\
\hline Major & VOL & & & \\
\hline \multirow[t]{4}{*}{ Ore Materials } & CINDER & & & \\
\hline & -- Geclogy -- & & & \\
\hline & .- Deposit Description .- & & & \\
\hline & --Individual Ore Bodies- & & & \\
\hline \multirow[t]{2}{*}{ Deposit Type } & VOLCANIC & & & \\
\hline & .- Exploration and Development .. & & & \\
\hline Production Size & Small & & & \\
\hline
\end{tabular}


Developent Status Little Developed Producer, Inactive

- Description of Workings --

Desc Workings Surface

Reference

- Reference -

PHILLIPS, K.A., 1987, ARIZONA INDUSTRIAL MINERALS: ARIZONA DEPARTMENT OF MINES AND MINERAL RESOURCES REPORT 4, 185 P.

Reference PEIRCE, H.W., 1990, ARIZONA GEOLOGICAL SURVEY INDUSTRIAL MINERAL CARD FILES.

Page 2 


\section{Mineral Resources Data System (MRDS)}

Report Title

Issue Date 00/00/00

Current Date Monday, April 7, 1997

Current Time 10:24:50

Number 34 of 103

Printed 34 of 103

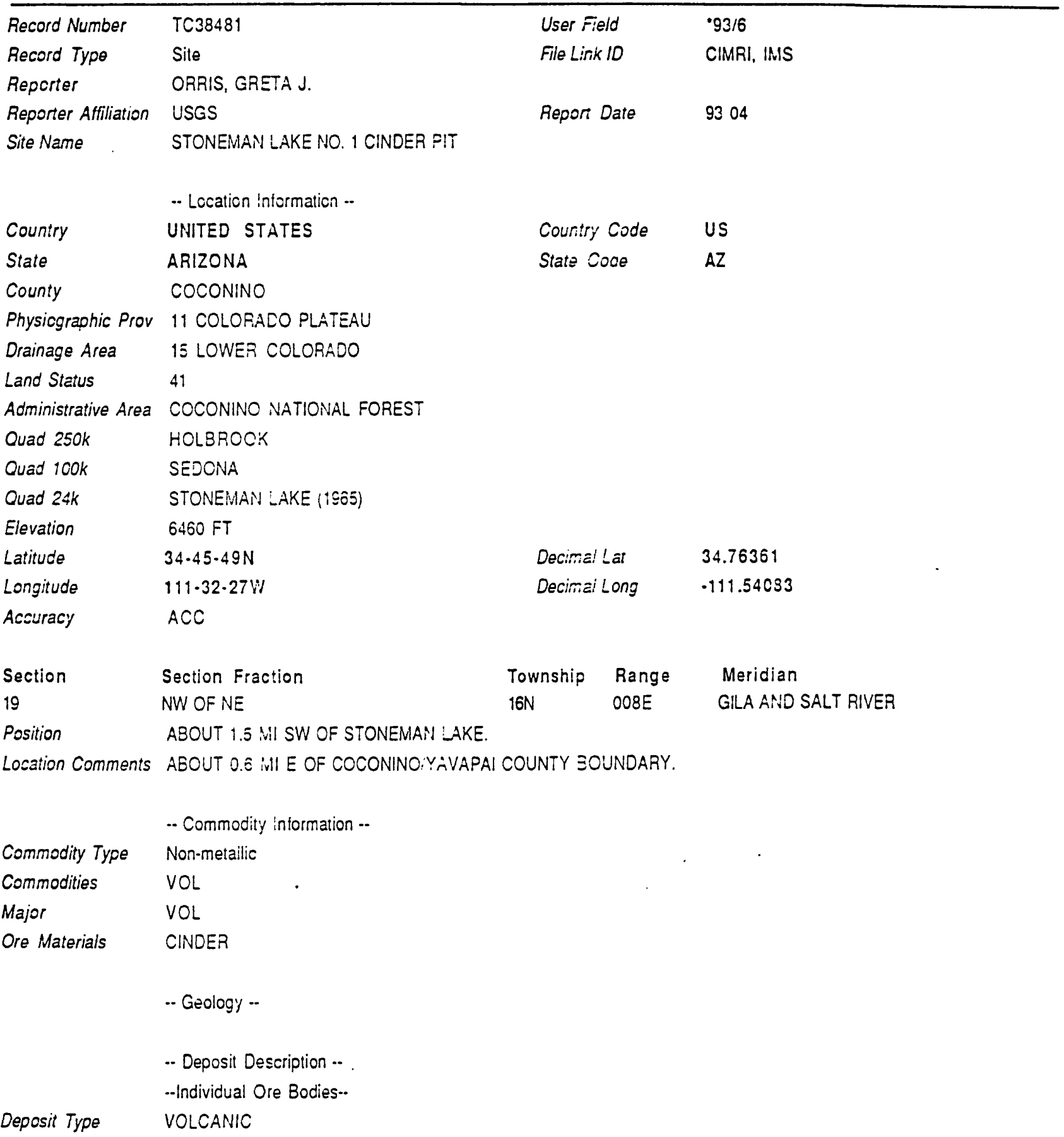

Deposit Type VOLCANIC

-- Exploration and Development -- 


\begin{tabular}{|c|c|}
\hline Record Number & (....Continued) \\
\hline Production Size & Small \\
\hline \multirow[t]{2}{*}{ Developent Status } & Little Developed Producer, Inactive \\
\hline & - Description of Workings .- \\
\hline \multirow[t]{2}{*}{ Desc Workings } & Surface \\
\hline & -- Reference - \\
\hline \multirow[t]{2}{*}{ Reference } & PHILLIPS, K.A., 1987, ARIZONA INDUSTRIAL MINERALS: ARIZONA DEPARTMENT OF MINES AND MINERAL \\
\hline & RESOURCES REPORT 4, $185 \mathrm{P}$. \\
\hline Reference & PEIRCE. H.W., 1990, ARIZONA GEOLOGICAL SURVEY INDUSTRIAL MINERAL CARD FILES. \\
\hline
\end{tabular}

PÆg๋ 2 


\section{Mineral Resources Data System (MRDS)}

Report Title

Issue Date 00/00/00

Current Date Monday, April 7. 1997

Current Time 10:24:50

\begin{tabular}{|c|c|c|c|c|}
\hline Record Number & TC38482 & \multicolumn{2}{|c|}{ User Fieid } & $93 / 6$ \\
\hline Record Type & Site & \multicolumn{2}{|c|}{ File Linix ID } & CIMRI, IMS \\
\hline Reporter & ORRIS, GREIA J. & & & \\
\hline Reporter Affiliation & USGS & \multicolumn{2}{|c|}{ Report Date } & 9304 \\
\hline Site Name & $\begin{array}{l}\text { SUNSET CRA } \bar{i} \equiv R \text { EAST NO. } 4 \text { CINDER PIT } \\
\text {-- Location Inisrmation - }\end{array}$ & & & \\
\hline Country & UNITED STATES & \multicolumn{2}{|c|}{ Counity Code } & US \\
\hline State & ARIZONA & \multicolumn{2}{|c|}{ State Code } & $A Z$ \\
\hline County & COCONINO & & & \\
\hline Physiographic Prov & 11 COLORACO PLATEAU & & & \\
\hline Drainage Area & 15 LOWER CCLORADO & & & \\
\hline Land Status & 41 & & & \\
\hline Administrative Area & COCONINO NATIONAL FOREST & & & \\
\hline Quad 250k & FLAGSTAFF & & & \\
\hline Quad 100k & FLAGSTAFF & & & \\
\hline Quad $24 k$ & SUNSET CRITER EAST (1S5S) & & & \\
\hline Elevation & $6970 \mathrm{FT}$ & & & \\
\hline Latitude & $35-21 \cdot 13 N$ & Decimal & Lat & 35.35361 \\
\hline Longitude & $111-29.05 \mathrm{~W}$ & Decinミ: & Long & -111.48472 \\
\hline Accuracy & $A C C$ & & & \\
\hline Section & Section Fraction & Township & Range & Meridian \\
\hline 30 & NW OF NW & $23 N$ & OOgE & GILA AND SALT RIVER \\
\hline \multirow[t]{2}{*}{ Position } & \multicolumn{3}{|l|}{ ABOUT $1 \mathrm{MI} \Xi \equiv$ OF SUNSET CRATER. } & \\
\hline & .. Commodity information .. & & & \\
\hline Commodity Type & Non-metallic & & & \\
\hline Commodities & VOL & & & $\cdot$ \\
\hline Major & VOL & & & \\
\hline \multirow[t]{4}{*}{ Ore Materials } & CINDER & & & \\
\hline & -- Geology -- & & & \\
\hline & -. Deposit Description -- & & & \\
\hline & --Individual Ore Bodies.. & & & \\
\hline \multirow[t]{2}{*}{ Deposit Type } & VOLCANIC & & & \\
\hline & .- Exploration and Development - & & & \\
\hline Production Size & Small & & & \\
\hline
\end{tabular}




\begin{tabular}{ll} 
Record Number & TC38482 $\quad$ (....Continued) \\
\hline Developent Status & Little Develcped Producer, Inaclive \\
& - Description of Workings - \\
Desc Workings & Surlace \\
& - Reference - \\
Reference & PHILLIPS, K.A., 1987, ARIZONA INDUSTRIAL MINERALS: ARIZONA OEPARTMENT OF MINES AND MINEPAL \\
Reference & RESOURCES REPORT 4, 185 P.
\end{tabular}

Page 2 


\section{Mineral Resources Data System (MRDS)}

Report Title

Issue Date 00/00/00

Current Date Monday, April 7, 1997

Current Time 10:24:50

Number 36 of 103

Record Number TC38483

User Field

Printed 36 of 103

Record Type

Site

File Link 10

$\cdot 93 / 6$

Reporter

ORRIS, GRETA J.

Reporter Affiliation USGS

Site Name

SUNSET CRATER EAST NO. 3 CINIDER PIT

Report Date $\quad 9304$

-. Location Information -.

$\begin{array}{llll}\text { Country } & \text { UNITED STATES } & \text { Country Code } & \text { US } \\ \text { State } & \text { ARIZONA } & \text { State Code } & \text { AZ }\end{array}$

County COCONINO

Physiographic Prov 11 COLORADO PLATEAU

Drainage Area 15 LOWER COLORADO

Land Status $\quad 41$

Administrative Area COCONINO NATTIONAL FOREST

Quad 250k FLAGSTAFF

Quad 100k FLAGSTAFF

Quad 24k

SUNSET CRATER EAST (1969)

Elevation $6375 \mathrm{FT}$

Latitude

$35 \cdot 16 \cdot 29 N$

Decimal Long

35.27472

Longitude

$111 \cdot 22 \cdot 45 \mathrm{~W}$

.111 .37916

Accuracy

ACC

$\begin{array}{lllll}\text { Section } & \text { Section Fraction } & \text { Township } & \text { Range } & \text { Meridian } \\ 19 & \text { SW OF SW } & 22 N & \text { O10E } & \text { GILA AND SALT RIVER }\end{array}$

Position ABOUT 5 MI SE OF SUNSET CRATER.

Location Comments NEAR THE SOUTHERN BASE OF COCHRANE HILL.

-. Commodity Intormation --

Commodity Type

Non-metallic

Commodities

VOL

Major

VOL

Ore Materials CINDER

-. Geology -

-- Deposit Description --

-.Individual Ore Bodies-

Deposit Type

VOLCANIC

-- Exploration and Development .-

Page 1 
Production Size Small

Developent Status

Little Develcped Producer, Inactive

- Description of Workings -

Desc Workings Surface

- Reference -

Reference

PHILLIPS, K.A., 1987, ARIZONA INCUSTRIAL MINEPALS: ARIZONA DEPARTMENT OF MINES AND MINEPAL RESOURCES REPORT 4, 185 P.

Reference PEIRCE, H.W., 1990, ARIZONA GECLOGICAL SURVEY INDUSTRIAL MINERAL CARD FILES.

$P a g=2$ 


\section{Mineral Resources Data System (MRDS)}

Report Title

Issue Date 00100:00

Current Date Monday, Aprii 7,1997

Current Time 10:24:50

Number 37 of 103

Record Number

TC36499

Record Type

Site

Reporter

ORRIS, GREA J.

Reporter Affiliation USES

WHITE HCFSE HILLS NO. 1 CINDER PIT

User Fieid

File Link 10

'93/6

Site Name

-. Location inicrmation -

Country UNITED STATES

Country Code US

State

ARIZONA

State Code

AZ

County

COCONINO

Physiographic Prov

11 COLCEA=O PLATEAU

Drainage Area

15 LOWEA COLORADO

Land Status

41

Administrative Area

COCONINO VATIONAL FOREST

Quad 250k

FLAGSTAR:=

Quad 100k

FLAGSTA:=

Quad 24k

WHITE - $-C F S E$ HILIS (1974)

Elevation

$8000 \mathrm{FT}$

Latitude

$35 \cdot 25 \cdot 39 N$

Longitude

$111 \cdot 44-\div 0 \% 9$

Decimal Lat

35.4275

Accuracy

$A C 0$

Section

Section Fraction

27

S2 OF S2

$\begin{array}{ll}\text { Township } & \text { Range } \\ 24 \mathrm{~N} & \text { O06E }\end{array}$

Meridian

GILA AND SALT RIVER

-- Commezily !niormation -.

Commodity Type

Commodities

Major

Ore Materials

Deposit Type

Developent Status
Non-mete!lic

VOL

VOL

CINCER

-. Geology -

-- Deposit Description --

--Irdividuaj Cre Bodies-

VOLCANIC
-- Exploraticn and Development --

Smail

Little Develsped Producer, Inactive
Printed 37 of 103 
- Description of Workings --

Desc Workings Surface

- Relerence -

Reference

PHILLIPS, K.A., 1987, ARIZONA INDUSTRIAL MINERALS: ARIZONA DEPARTMENT OF MINES AND MINESAL RESOURCES REPORT 4, $185 P$.

Reference

PEIRCE. H.W., 1990, ARIZONA GECLOGICAL SURVEY INDUSTRIAL MINERAL CARD FILES.

$P \approx g=2$ 


\section{Mineral Resources Data System (MRDS)}

Report Title

Issue Date 00/00/00

Current Date Monday, April T, 1997

Current Time 10:24:50

Number 38 of 103

Record Number TC36500

Record Type Site

Reporter

ORRIS, GRETA J.

Reporter Affiliation USGS

User Fieid U94/11

File Link 10

CIMRI, IMS

Editor Name

ORRIS, GRETA J.

Site Name

$R$ USGS $\quad 4 i 1 / 93$

Repcrt Date

9304

Printed 38 of 103

Country
State
County
Physiographic Prov
Drainage Area
Land Status
Acministrative Area
Quad 250k
Quad 100k
Quad 24k
Latitude
Longitude
Acauracy
Section
19
Position

SUGAFLOAF PפAK

-- Location iniormation -

UNITED STATES

Couniry Code

US

ARIZONA

State Code

AZ

COCONINO

11 COLOFACO PLATEAU

15 LOWEA COLORACO

40

COCONINC NATIONAL FOREST

FLAGSTAFF

FLAGSTAFF

SUNSET CRATER WEST (1983)

$35.21 .35 \mathrm{~N}$

Decimal Lat

35.35972

$111-34-57 \mathrm{~W}$

Decimal Long

.111 .5825

$\mathrm{ACC} \div 0.5 \mathrm{ill}$

Section Fraction

Township

Range

Merician

$23 \mathrm{~N}$

OOBE

GILA AND SALT RIVER

ABOUT 4.5 MI W OF SUNSET CRATER.

Location Comments THERE AFE 3 PIUMICE PITS IN SEح. 19. LAT-LONG IS FOR PIT IN SW'4 OF SE:4.

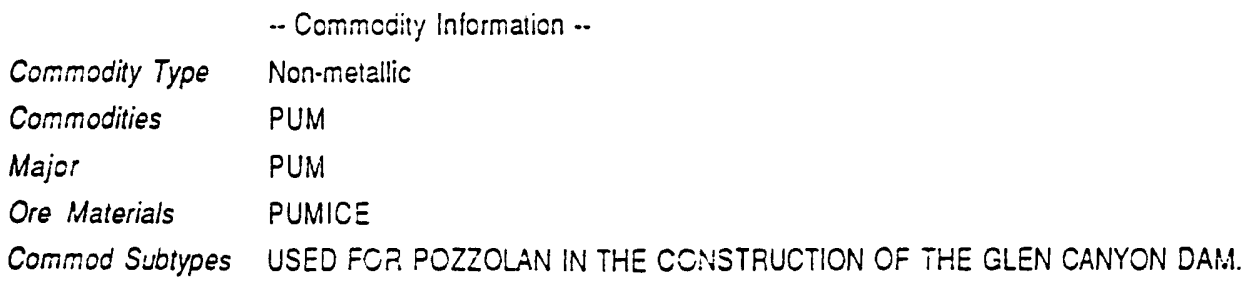

- Geology ..

Age Mineralization MIO-PL1O

Host Rock Type Name

RHYOLITIC PUMICE
Age Host Rock Unit Name

MIO-PLIO
Age 


\begin{tabular}{|c|c|}
\hline Record Number & (....Continued) \\
\hline & -- Deposit Cescription .- \\
\hline & -Individual Cie Bodies- \\
\hline Deposit Type & VOLCANIC \\
\hline Thickness & 200. \\
\hline \multirow[t]{3}{*}{ Deposit Desc Comm } & PUMICE FFIGMENTS ARE COARSE TO FINE, ANGULAR TO ROUNDED, BEDDED OR UNSORTED, AND \\
\hline & LOOSELY CONSOLIDATED. THE DEPOSITS ARE UP TO 200 FT THICK. \\
\hline & .- Exploraticn and Development .. \\
\hline Production Size & Small \\
\hline Developent Status & Developed ::zducer, Inactive \\
\hline \multirow[t]{2}{*}{ Development MS } & HYDROLOGOIC UNIT CO \\
\hline & -- Descripticn of Workings .. \\
\hline Desc Workings & Surface \\
\hline \multirow[t]{3}{*}{ General Comm } & THIS RECCFO INCLUDES DATA FROM DUPLICATE RECORD TC35342 WHICH HAS BEEN DELETED FEOM \\
\hline & MRDS. \\
\hline & -. Referanc@ - \\
\hline \multirow[t]{2}{*}{ Reference } & PHILLIPS, K.A.. 1987. ARIZONA INOUSTRIAL MINERALS: ARIZONA DEPARTMENT OF MINES AND MINEFAL \\
\hline & RESOURCES REPORT 4. $185 \mathrm{P}$. \\
\hline Reference & PEIRCE, $: .: \%$. 19SO, ARIZONA GEOLOGICAL SURVEY INDUSTRIIAL MINERAL CARD FILES. \\
\hline
\end{tabular}

Page 2 


\section{Mineral Resources Data System (MRDS)}

Report Title

Issue Date 00/00/00

Current Date Monday, April $7,1 \leqq 97$

Current Time 10:24:50

Number 39 of 103

\begin{tabular}{|c|c|c|c|c|}
\hline \multicolumn{2}{|c|}{ Current Date Monday, April $\bar{i}, 1 \leq 97$} & \multicolumn{2}{|c|}{ Current Time 10:24:50 } & \multirow[t]{2}{*}{ Printed 39 of 103} \\
\hline Record Number & TC38484 & \multicolumn{2}{|c|}{ User Fieid } & \\
\hline Record Type & Site & \multicolumn{2}{|c|}{ File Link 10} & CIMRI, IMS \\
\hline Reporter & ORRIS, GFETAJ. & & & \\
\hline Reporter Affiliation & USGS & \multicolumn{2}{|c|}{ Repon Date } & 9304 \\
\hline \multirow[t]{2}{*}{ Site Name } & SUNSET CFATER EAST NO. 2 CINCER PIT & & & \\
\hline & -- Location !nismation -. & \multirow{2}{*}{\multicolumn{2}{|c|}{ Counisy Code }} & \\
\hline Country & UNITED STATES & & & US \\
\hline State & ARIZONA & \multirow{2}{*}{\multicolumn{2}{|c|}{ State Code }} & $A Z$ \\
\hline County & COCONINC & & & \\
\hline Physiographic Prov & 11 COLCF:IZC PLATEAU & & & \\
\hline Drainage Area & 15 LOWE: COLORADO & & & \\
\hline Land Status & 41 & & & \\
\hline Administrative Area & COCONINC VATIONAL FOREST & & & \\
\hline Quad 250k & FLAGSTAR:= & & & \\
\hline Quad 100k & FLAGSTAZ=: & & & \\
\hline Quad 24k & SUNSE: CRATER EAST (1969) & & & \\
\hline Elevation & $6550 \mathrm{FT}$ & & & \\
\hline Latitude & $35 \cdot 15 \cdot 40 \mathrm{~N}$ & \multicolumn{2}{|c|}{ Decimal Lat } & 35.26111 \\
\hline Longitude & $111 \cdot 28.29: W$ & \multicolumn{2}{|c|}{ Decimai Long } & -111.47472 \\
\hline Acsuracy & $A C C$ & & & \\
\hline Section & Section Fraction & Township & Range & Meridian \\
\hline 29 & SW OF NW & $22 \mathrm{~N}$ & OOgE & GILA AND SALT RIVER \\
\hline Position & ABOUT 7 U. S OF SUNSET CRATER. & & & \\
\hline \multirow[t]{2}{*}{ Location Comments } & AEOUT $0 . \Xi: \because 1$ NW OF ONEILL CRIATER. & & & \\
\hline & -- Commodity !nformation .- & & & \\
\hline Commodity Type & Non-metallic & & & \\
\hline Commodities & VOL & & & \\
\hline Major & VOL & & & \\
\hline \multirow[t]{4}{*}{ Ore Materials } & CINDER & & & \\
\hline & .. Geolegy - & & & \\
\hline & -- Deposit Jescriplion .. & & & \\
\hline & -Individual Ore Bodies-- & & & \\
\hline Deposit Type & VOLCANIC & & & \\
\hline
\end{tabular}

Page 1 
Production Size

Small

Developent Status Little Develcped Producer, Inactive

- Description of Workings --

Dese Workings

Surface

- Reference -

Reference

PHILLIPS, K.A., 1987, ARIZONA INCUSTRIAL MINERALS: ARIZONA DEPARTMENT OF MINES AND MINEEAAL RESOURCES REPORT 4, 185 P.

Reference PEIRCE, H.W., 1990, ARIZONA GEOLOGICAL SURVEY INDUSTRIAL MINERAL CAFD FILES.

Pagz 2 


\section{Mineral Resources Data System (MRDS)}

Report Title

Issue Date 00/00/00

Current Date Monday, April 7, 1997

Number 40 of 103

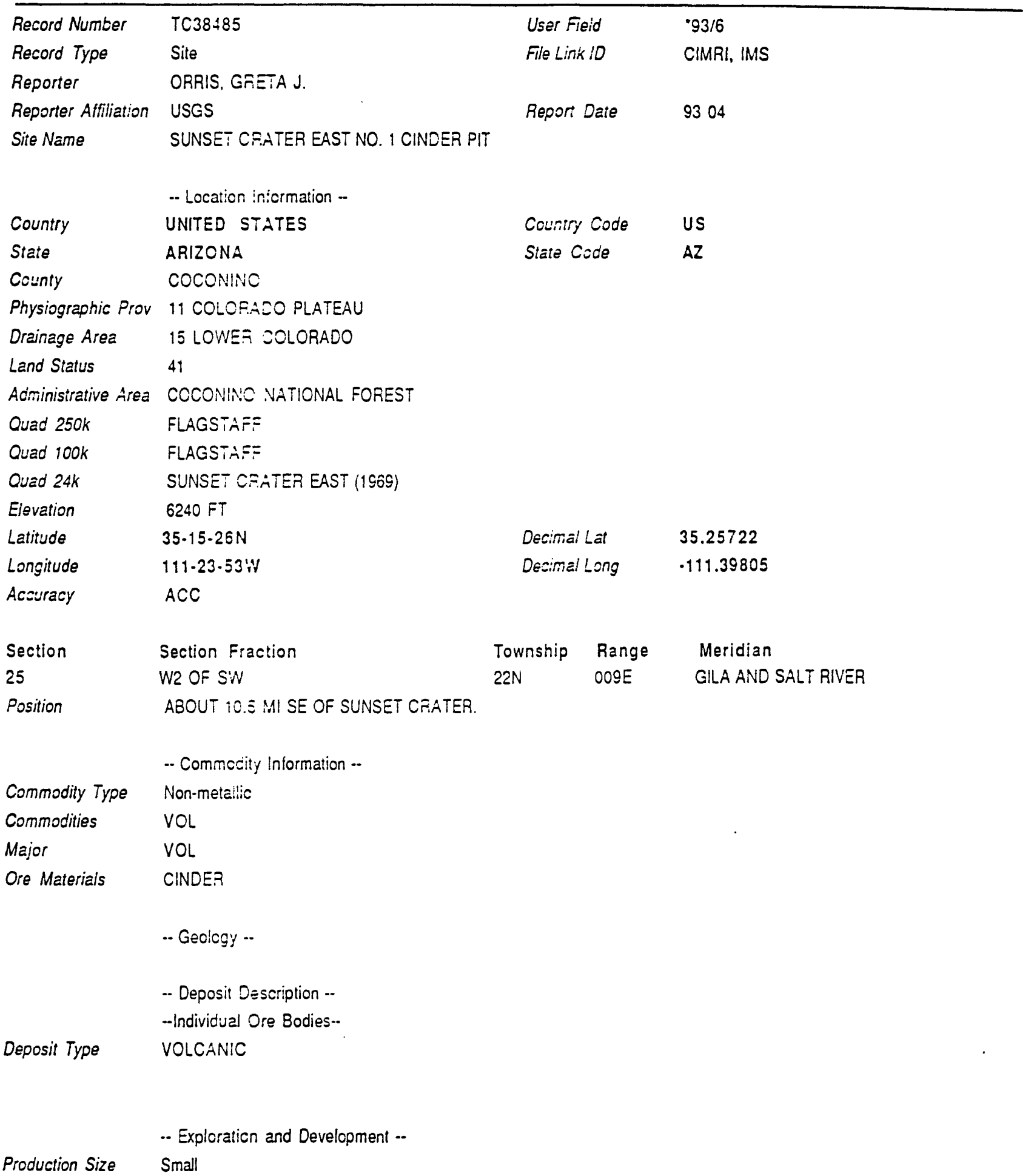

Page 1 
Developent Status Little Develcped Producer, Inactive

- Description of Workings -

Dese Workings Surlace

Reference

- Reference -

Reterence PHILLIPS, K.A., 1987, ARIZONA INCUSTRIAL MINERALS: ARIZONA DEPARTMENT OF MINES AND MINERAL RESOURCES F.EPORT 4, 185 P.

Reference PEIRCE, H.W., 1990, ARIZONA GECLOGICAL SURVEY INDUSTRIAL MINERAL OAFD FILES.

Page 2 


\section{Mineral Resources Data System (MRDS)}

Report Title

Issue Date 00/00/00

Current Date Monday, April 7, 1997

Current Time 10:24:50

Number 41 of 103

Printed 41 of 103

Record Number
Record Type
Reporter
Reporter Affiliation
Site Name

TC38486

Site

User Field

$\cdot 93 / 6$

File Link 10

CIMRI, IMS

ORPIS, GRETA J.

USGS

Repcrt Date $\quad 9304$

-- Location Inicrmation --

Country

UNITED STATES

Couning Code

US

State

ARIZONA

County

COCONINO

State Code

AZ

Physiographic Prov 11 COLORACO PLATEAU

Drainage Area 15 LOWER COLORADO

Land Siatus

41

Administrative Area COCONINO NATIONAL FOREST

Quad 250k

FLAGSTAFF

Quad 100k

FLAGSTAFF

Ouad 24k

DUTTON HILL (1980)

Elevation

$7260 \mathrm{FT}$

Latitude

$35 \cdot 05.05 \mathrm{~N}$

Decimal Lat

35.08472

Longitude

$111.49 .08 \mathrm{~W}$

Decirial Long

.111 .81888

Accuracy

ACC

Section

Section Fraction

NE OF SW

Township Range

Meridian

25

ABOUT 2 MII S OF DUTTON HILI.

$20 \mathrm{~N}$

OOSE

GILA AND SALT RIVER

Position

-- Commejity Intormation .-

Commodity Type

Non-mete!lic

Commodities

VOL

Major

VOL

Ore Materials

CINDER

-. Geology -

- Deposi: Description --

--Individual Ore Bodies--

Deposit Type VOLCANIC

Production Size

-. Exploration and Development -.

Small

Page : 
Developent Status Little Developed Producer, Inactive

-- Description of Workings --

Desc Workings Surlace

- Reference -

Reference

PHILLIPS, K.A., 1987, ARIZONA INCLISTRIAL MINERALS: ARIZONA DEPARTMENT OF MINES AND MINEFAL RESOURCES REPORT 4, 185 P.

Reference PEIRCE. H.W., 1990, ARIZONA GECLOGICAL SURVEY INDUSTRIAL MINERAL CARD FILES.

Page 2 


\section{Mineral Resources Data System (MRDS)}

Report Title

Issue Date 00/00/00

Current Date Monday, April 7. 1997

Current Time 10:24:50

Number 42 of 103

Printed 42 of 103

\begin{tabular}{|c|c|c|c|c|}
\hline Record Number & TC38487 & \multicolumn{2}{|c|}{ User Fieid } & $\cdot 93 i 6$ \\
\hline Record Type & Sile & \multicolumn{2}{|c|}{ File Linik 10} & CIMRI, IMS \\
\hline Reporter & ORRIS, GREIA J. & & & \\
\hline Reporter Affiliation & USGS & \multicolumn{2}{|c|}{ Report Jate } & 9304 \\
\hline \multirow[t]{2}{*}{ Site Name } & FLAGSTAFF WEST NO. 2 CINDER F!T & & & \\
\hline & - Location Inicrmation - & \multirow{2}{*}{\multicolumn{2}{|c|}{ Courity Code }} & \\
\hline Country & UNITED STATES & & & US \\
\hline State & ARIZONA & \multirow{2}{*}{\multicolumn{2}{|c|}{ State Code }} & $A Z$ \\
\hline County & COCONINO & & & \\
\hline Physiographic Prov & 11 COLORINDO PLATEAU & & & \\
\hline Drainage Area & 15 LOWES COLORADO & & & \\
\hline Land Status & 41 & & & \\
\hline Administrative Area & COCONINO NATIONAL FOREST & & & \\
\hline Quad $250 \mathrm{k}$ & FLAGSTAFF & & & \\
\hline Ouad 100k & FLAGSTAFF & & & \\
\hline Quad $24 k$ & FLAGSTAFT NEST (1983) & & & \\
\hline Elevation & $7120 \mathrm{FT}$ & & & \\
\hline Latitude & $35 \cdot 10 \cdot 18 \mathrm{~N}$ & \multicolumn{2}{|c|}{ Decima: tat } & 35.17166 \\
\hline Longitude & $111.41 .53 W$ & \multicolumn{2}{|c|}{ Decimai Long } & .111 .69944 \\
\hline Accuracy & $A C C$ & & & \\
\hline Section & Section Fraction & Township & Range & Meridian \\
\hline 30 & NW OF SW & $21 \mathrm{~N}$ & OOTE & GILA AND SÁLT RIVER \\
\hline \multirow[t]{2}{*}{ Position } & ABOUT $2 . \equiv$ SII SW OF FLAGSTAFF. & & & \\
\hline & -- Commecity intormation -. & & & \\
\hline Commodity Type & Non-metailic & & & \\
\hline Commodities & VOL & & & \\
\hline Major & VOL & & & \\
\hline \multirow[t]{4}{*}{ Ore Materials } & CINDER & & & \\
\hline & .- Geology - & & & \\
\hline & -- Deposit Description -- & & & \\
\hline & --Individual Ore Bodies-- & & & \\
\hline \multirow[t]{2}{*}{ Deposit Type } & VOLCANIC & & & \\
\hline & -. Exploration and Development -. & & & \\
\hline Production Size & Small & & & \\
\hline
\end{tabular}




\begin{tabular}{ll} 
Record Number & TC38487 (....Continued) \\
\hline Developent Status & Little Developed Producer, Inactive \\
& - Description of Workings -- \\
Dese Workings & Surface \\
& - Reference - \\
Reference & PHILLIPS. K.A., 1987, ARIZONA INCLSTRIAL MINERALS: ARIZONA DEPARTMENT OF MINES AND MINEPAL \\
Reference & RESOUR.CES REPORT 4, 185 P.
\end{tabular}

Pag̨?

$B-82$ 


\section{Mineral Resources Data System (MRDS)}

Report Title

Issue Date 00100/00

Current Date Monday, Aprit T. 1997

Current Time 10:24:50

Number 43 of 103

Printed 43 of 103

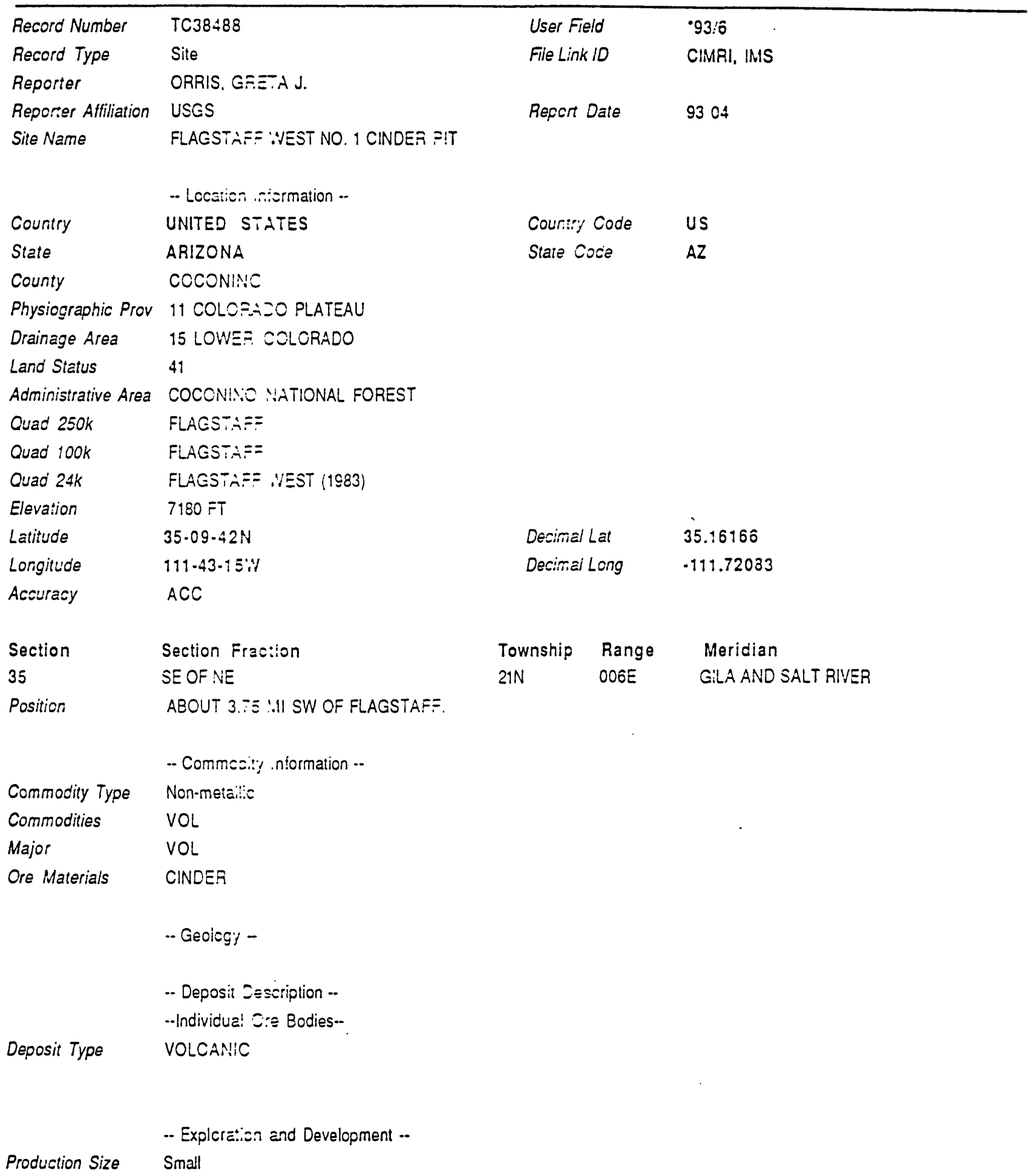

Page 1 


Record Number TC38488 (....Continued)

Developent Slatus Little Developed Producer, Inactive

- Description of Workings .-

Desc Workings Suriace

-- Relerence -

Reference

PHILLIPS, K.A., 1987, ARIZONA INCUSTRIAL MINERALS: ARIZONA DEPARTMENT OF MINES AND MINESAL RESOURCES REPORT 4, 185 P.

Reference PEIRCE, H.W., 1990, ARIZONA GECLOGICAL SURVEY INDUSTRIAL MINERAL CARD FILE.

Page 2 


\section{Mineral Resources Data System (MRDS)}

Report Title

Issue Date 00/00/00

Current Date Monday, April 7, 1997

Number 44 of 103

Record Number

TC36889

Reccro Type

Site

Reporter

ORRIS, GREIA J.

Reperter Affiliation USGS

Site Name

SEDGE SPRING CINDER PIT

User Field

File Lini 10

Printed 44 of 103

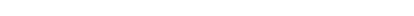

Report Date

-93/6

- Location Inicimation -

Country

UNITED STATES

Couniry Code

US

State

ARIZONA

State Code

$A Z$

County COCONINO

Physiographic Prov 11 COLCRACC PLATEAU

Drainage Area

15 LOWER COLORADO

Land Siatus

41

Administrative Area

Quad 250k

COCONINO NATIONAL FOREST

Quad 100k

HOLBRCOK

Quad 24k

SEDONA

Elevation

MORINON LAKE (19T\$)

Latitude

7240 FT

Longitude

$34 \cdot 54 \cdot 13 \mathrm{~N}$

$111 \cdot 25 \cdot 37 W$

Decimai Lat

34.90361

Accuracy

$A C C$

Section

34

Position

Section Fraction

NW OF NE

Decimai Long

$-111.42694$

ABOUT 2 MII SSE OF MORMON LAKE, AZ.

Township Range Meridian

I8N OOgE GILAAND SALT RIVER

$\begin{array}{ll} & \text {.. Commodity Iniormation } \\ \text { Commodity Type } & \text { Non-metallic } \\ \text { Commodities } & \text { VOL } \\ \text { Major } & \text { VOL } \\ \text { Ore Materials } & \text { CINOER } \\ & \text {.. Geology -- } \\ & \\ & \text {.- Deposit Description .. } \\ & \text {--Individual Ore Bodies- } \\ & \text { VOLCANIC }\end{array}$

-. Exploration and Develcpment -.

Production Size Smal! 
Developent Status Little Developed Producer, Inactive

$\begin{array}{ll}\text { Desc Workings } & \begin{array}{l}\text {-- Description of Workings -- } \\ \text { Surface }\end{array} \\ & \text {-- Reference - } \\ \text { Reference } & \text { PHILLIPS, K.A., 1987, ARIZONA INCUSTRIAL MINERALS: ARIZONA DEPARTMENT OF MINES AND MINERAL } \\ & \text { RESOURCES REPORT 4, 185 P. } \\ \text { Reference } & \text { PEIRCE, H.W., 1990, ARIZONA GEOLOGICAL SURVEY INDUSTRIAL MINERAL CAFD FILE. }\end{array}$

$$
\text { Page } 2
$$




\section{Mineral Resources Data System (MRDS)}

Report Title

Issue Date 00/00/00

Current Date Monday, Aprii 7, 1997

Current Time 10:24:50

Number 45 of 103

Record Number

TC36890

User Field

Printed 45 of 103

Record Type

Sile

Reporter

ORRIS, GEETA J.

Reporter Affiliation

USGS

Site Name

KINNIKIN:CK LAKE

File Link 10

$\cdot 93 / 6$

Report Date

CIMRI, IMS

-. Locatic-: Inicrmation .-

Counity

UNITED STATES

Couniry Code

US

State

ARIZONA

State Code

AZ

County

COCONIA:O

Physicgraphic Prov 11 COLCFACO PLATEAU

Drainage Area 15 LOWEF COLORADO

Land Status 41

Admiristrative Area COCONINO NATIONAL FOREST

Quad 250k

HOLBFCOK

Quad $100 k$

SEDCN

Quad $24 k$

KINNIKI::OK L-AKE (1970)

Elevation

$7490 \mathrm{FT}$

Latituce

$34.55 .53 \mathrm{~N}$

Decimal Lat

34.93277

Longitude

$111-21.43 \mathrm{~N}$

Decimal Long

.111 .36194

Accuracy

ACC

Section

Section Fraction

20

NW OF N:H

Township Range

Meridian

Location Comments NEAR PE:AK ON S SIDE OF PINE HILL.

$18 \mathrm{~N}$

O10E

GILA AND SALT RIVER

- Commezity Iniormation ..

Commocity Type

Non-meia:i:e

Commodities

$\mathrm{VOL}$

Major

VOL

Ore Materials CINDER.

.. Geolog: -

- Deposit Description -.

-.Individual Ore Bodies-

Deposit Type

VOLCANIC

-. Explora:ion and Development --

Production Size

Small

Page 1 


\begin{tabular}{ll} 
Record Number & TC36890 $\quad$ (....Continued) \\
\hline Developent Status & Little Developed Producer, Inactive \\
& - Description of Workings - \\
Desc Workings & Surface \\
& - Reference - \\
Reference & PHILLIPS. K.A., 1987, ARIZONA INDUSTRIAL MINERALS: ARIZONA DEPARTMENT OF MINES AND MINE.AL \\
& RESOURCES REPORT 4, 185 P. \\
Reference & PEIRCE. H.W. 1990, ARIZONA GEOLOGICAL SURVEY INDUSTRIAL MINERAL CARD FILE.
\end{tabular}

Page 2 


\section{Mineral Resources Data System (MRDS)}

\section{Report Title}

Issue Date 00/00/00

Current Date Monday, Afril T, 1997

Time 10:24:50

Number 46 of 103

Record Number

TC368:

Record Type Sile

Printed 46 of 103

Reporter

ORRIS. GREIA J.

Reporter Affiiiation USGS

Site Name

KENDFICK PEAK NO. 2 CINDER PIT

-. Locz::on inicrmaticn -

Country

UNITED STATES

Courity Code

US

State

ARIZONA

State Code

AZ

County

COCONINO

Physiographic Prov 11 COLCPACO PLATEAU

Drainage Area

15 LOWER COLORADO

Land Status

41

Administrative Area COCONINO NATIONAL FOREST

Quad 250k

FLAGSTAFF

Quad 100k

FLAGSTAFF

Quad 24k

KENDE::K YEAK (i气ลิ)

Elevation

$7320 \mathrm{FT}$

Latitude

$35 \cdot 29 \cdot: 5 \mathrm{~N}$

$111.48 \cdot 27 W$

Decinal Lat

35.49583

Longitude

$A C C$

Decimai Long

.111 .8075

Accuracy

Section Fraction

Township

Range

Meridian

Section

NW OF NNW

24N 006E

GILA AND SALT RIVER

Location Comments 2 MI E CF THE PEAK OF SLATE MOUNTAIN. ON SW FLANK OF A SMALL HILL.

-. Commasity iniormaiton .-

Commodity Type

Non-me:allic

Commodities

VOL

Major

VOL

Ore Materials

CINDEA

-. Geolicgy -

-- Deposit Description --

--Indivicual Ore Bocies-

Deposit Type VOLCANIC

-- Explcration and Development ..

Production Size

Small

Page 1 
- Description of Workings --

Desc Workings

$$
\text { Surface }
$$

Reference

- Reierence -

Reference PHILLIPS, K.A., 1987, ARIZONA INOUSTRIAL MINERALS: ARIZONA DEPARTMENT OF MINES AND MINERAL RESOURCES REPORT 4, 185 P. PEIRCE, H.W., 1990, ARIZONA GECLOGICAL SURVEY INDUSTRIAL MINERAL CARD FILE.

Pąe 2 


\section{Mineral Resources Data System (MRDS)}

\section{Report Title}

Issue Date 00100100

Current Date Monday, April i. 1997

Current Time 10:24:50

Number 47 of 103

\begin{tabular}{|c|c|c|c|c|}
\hline Record Number & TC363ฐ2 & \multicolumn{2}{|c|}{ User Field } & $\bullet 93 / 6$ \\
\hline Record Type & Site & \multicolumn{2}{|c|}{ File Link 10} & CIMRI, IMS \\
\hline Reporter & ORRIS, GEETA J. & & & \\
\hline Repcrier Affiliation & USES & \multicolumn{2}{|c|}{ Report Date } & 9304 \\
\hline Site Name & \multicolumn{3}{|l|}{ KENDF:CK PEAK NO. 1 CINDER PIT } & \\
\hline & \multicolumn{3}{|l|}{-- Location iniormation -- } & \\
\hline Country & UNITED STATES & \multicolumn{2}{|c|}{ Country Code } & US \\
\hline State & ARIZONA & \multicolumn{2}{|c|}{ State Code } & $A Z$ \\
\hline County & \multicolumn{3}{|l|}{ COCONII:O } & \\
\hline Ohysicgraphic Prov & \multicolumn{3}{|l|}{11 COLCFIDO PLATEAU } & \\
\hline Drainage Area & \multicolumn{3}{|l|}{15 LONEA COLORADO } & \\
\hline Land Status & \multicolumn{3}{|l|}{41} & \\
\hline Administrative Area & \multicolumn{3}{|l|}{ COCONHAC NATIONAL FOREST } & \\
\hline Qua: $250 k$ & \multicolumn{3}{|l|}{ FLAGSim:= } & \\
\hline Quż: :00k & \multicolumn{3}{|l|}{ FLAGSTARF } & \\
\hline Quza $24 k$ & \multicolumn{3}{|l|}{ KENDE:CKK PEAK (1986) } & \\
\hline Eieva:ion & \multicolumn{3}{|l|}{$8040 F T$} & \\
\hline atituce & $35 \cdot 22 \cdot 5 \Xi N$ & \multicolumn{2}{|c|}{ Decimai Lat } & 35.38222 \\
\hline ongitude & $111-47 \cdot 0 \div 6$ & \multicolumn{2}{|c|}{ Decimal Long } & $-111.78 \div 44$ \\
\hline Acsuracy & \multicolumn{3}{|l|}{$A C C$} & \\
\hline jection & Section Fraction & Township & Range & Meridian \\
\hline 7 & $\mathrm{~N} 2 \mathrm{OF} \mathrm{N} 2$ & $23 \mathrm{~N}$ & OOGE & GILA AND SALT RIVER \\
\hline ocation Comments & \multicolumn{3}{|l|}{ ABOUT 4 :A1 ESE OF KENDRICK FEAK. } & \\
\hline & \multicolumn{3}{|l|}{-- Commzsity Iniormation .. } & \\
\hline Commedity Type & \multicolumn{3}{|l|}{ Non-m气:alii } & \\
\hline Commodities & \multicolumn{3}{|l|}{ VOL } & . \\
\hline lajor & \multicolumn{3}{|l|}{ VOL } & \\
\hline Pre Waterials & \multicolumn{3}{|l|}{ CINDE: } & \\
\hline & \multicolumn{3}{|l|}{.. Geolcsy - } & . \\
\hline & \multicolumn{4}{|l|}{-- Deposit Jescription -- } \\
\hline & \multicolumn{4}{|l|}{--Individual Ore Bodies.-. } \\
\hline leposit Type & \multicolumn{3}{|l|}{ VOLCAHIIC } & \\
\hline & -- Expicie::sn and Development -- & & & \\
\hline roduction Size & Small & & & \\
\hline
\end{tabular}


Developent Status Little Developed Producer, Inactive

- Description of Workings -.

Desc Workings Surface

Reference

- Relerence -

Reference

PHILLIPS, K.A., 1987, ARIZONA INCUSTRIAL MINERALS: ARIZONA DEPARTMAENT OF MINES AND MINEFAL RESOURCES REPORT 4, 185 P.

PEIRCE, H.W., 1990. ARIZONA GEOIOGICAL SURVEY INDUSTRIAL MINEPAL CARD FILE.

Page 2 


\section{Mineral Resources Data System (MRDS)}

Report Title

Issue Date 00/00/00

Current Date Monday, Acril ᄀ., 1997

Current Time :0:24:50

Number 48 of 103

Printed 48 of 103

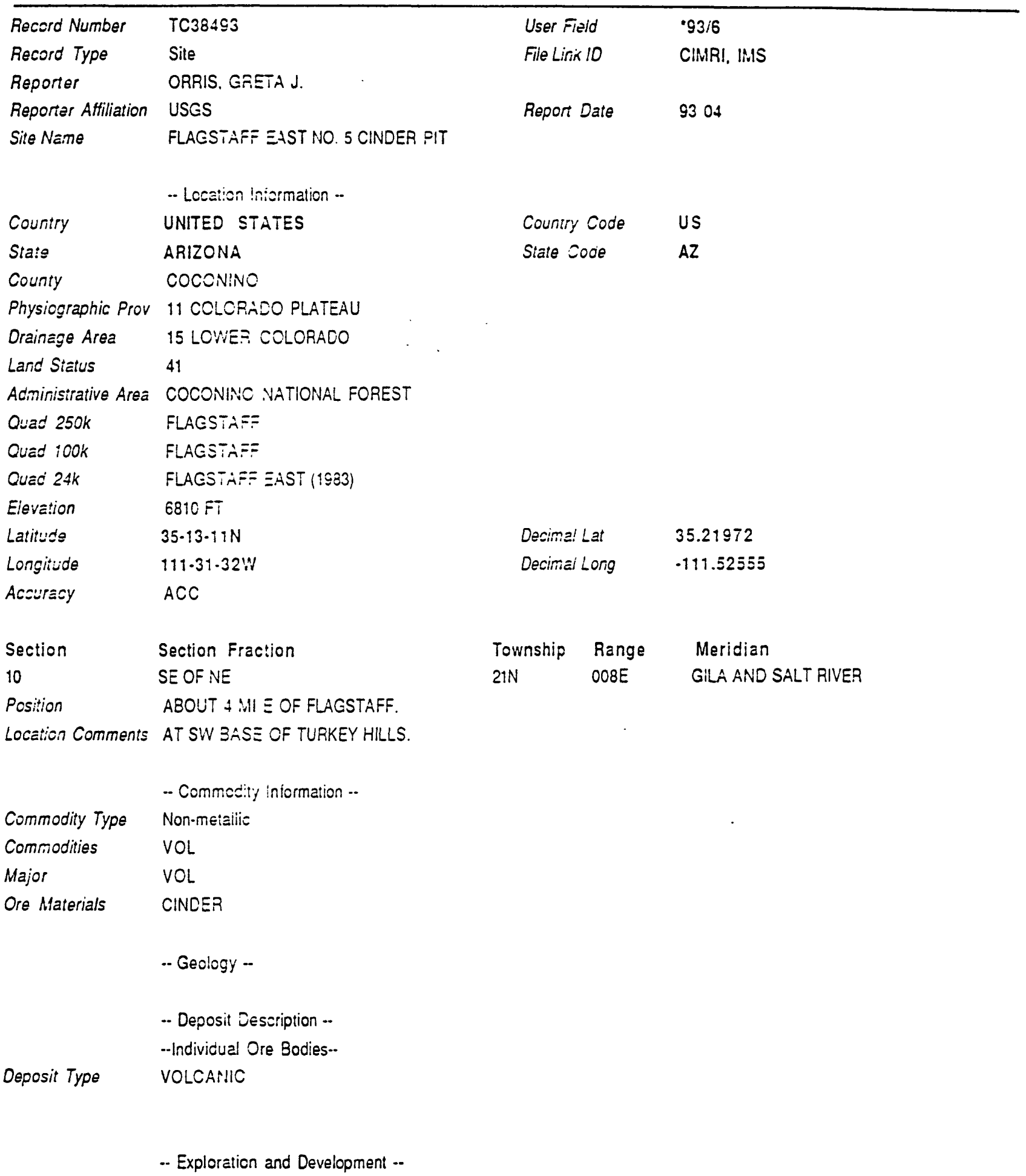

Page 1 
Production Size Small

Developent Status Little Developed Producer, Inactive

- Description of Workings ..

Desc Workings Surface

- Reference -

Reference

PHILLIPS, K.A., 1987, ARIZONA INDUSTRIAL MINERALS: ARIZONA DEPARTIUENT OF MINES AND MINEFAL RESOURCES REPORT 4, 185 P.

Reference PEIRCE, H.W., 1990, ARIZONA GEOLOGICAL SURVEY INDUSTRIAL MINERAL CARD FILE.

Page 2 


\section{Mineral Resources Data System (MRDS)}

Report Title

Issue Date 00/00/00

Current Date Monday, Aprit T, 1997

Number 49 of 103

Record Number

TC38494

Recsrd Type

Site

Reporter

ORFIS. GFETA J.

Reporter Affiliation USGS

Site Name

EBERT MCLNTAIN CINDER PIT

- Lccaicon iniormation -.

Country

UNITED STATES

Country Code

US

Stàe

ARIZONA

State Code

AZ

County

COCONINIO

Physizgraphic Prov 11 COLOFidDO PLATEAU

Drainage Area 15 LOWEF COLORADO

Land Status 41

Administrative Area KAIEẪ NATiONAL FOREST

Quad 250k FLAGSTHF=

Quas':00k CAMEADN

Quad 62.5K EBEFT UICUNTAIN

Quac' $24 k$

Elevation

ESERT :.:CLNTAIN (1989)

Elevation

$6800=$ ?

Longitude

$35 \cdot 33 \cdot 44 \mathrm{~N}$

Decimal Lat

35.56222

Acouracy

$111 \cdot 5 \vdots-59 W$

Decimal Long

.111 .93305

Section

Section Fraction

11

CENTER

Township Range

Meridian

Loca:ion Comments ON NE F_ANKK OF EBERT MOUNTAIN.

$25 \mathrm{~N}$

OO4E

GILA AND SALT RIVER

-. Commazity Information ..

Commodity Type Non-metaiiiz

Commodities VOL

Major VOL

Ore Materials CINDE?

- Geology -

-. Deposit Description ..

--Individual Ore Bodies.-

Deposit Type VOLCANIC

-. Explciation and Development .- 
Production Size Small

Developent Status Little Developed Producer, Inactive

- Description of Workings --

Desc Workings Surface

Reference

- Reference -

PHILLIPS, K.A., 1987, ARIZONA INCUSTRIAL MINEPALS: ARIZONA DEPARTMENT OF MINES AND MINEFAL RESOURCES REPORT 4, 185 P.

Reierence PEIRCE, H.W., 1990, ARIZONA GEOLOGICAL SURVEY INDUSTRIAL MINERAL CARD FILE.

“ $P \equiv \equiv \equiv 2$ 


\section{Mineral Resources Data System (MRDS)}

Report Title

Issue Date 00100100

Current Date Monday, Ap̣ril T, 1997

Number 50 of 103

Record Number

TC38495

User Field

Printed 50 of 103

Record Type Site

Reporter ORRIS, GFETAJ.

Reporter Affiliation USGS

Site Name SECTION :s HillL CINDER PIT

File Link 10

• $93 / 6$

CIMRI. IMS

Report Date $\quad 9304$

-. Losation i.tisrmation -

Counity

UNITED STATES

Counicy Code

US

State

ARIZONA

State cooe

$A Z$

County

COCONINC

Physiographic Prov 11 COLOFĩJO PLATEAU

Drainage Area 15 LOWEA SOLORADO

Land Siatus $\quad 41$

Administrative Area KAIBAB NAT:ONAL FOREST

Ouad 250k FLAGSTAF=

QUaE iOOK FLACSTAF:

Quac 24k PARKS 19E:!

Eievation $7300=T$

Latituce $\quad 35.22 .241 \mathrm{~N}$

Longitude $\quad 111.50 .22: \%$

Decimiai lat

35.37333

Acciracy

ACC

Section

16

Section Fracion

NW CF SE

Decim:a! Long

.111 .97277

Position

ABCUT 8 :II $Y$ OF PARKS.

.. Commeci:.; !nformation .-

Commodity Type

Non-metalic

Commodities VOL

Major VOL

Ore Materials CINDEA

- Geology -

-. Depcsit Sescription --

-. Individual Sre Bodies.-

Deposit Type VOLCANIC

Township Range Meridian

23N O04E GILA AND SALT RIVER

23N O04E GILA AND SALT RIVER

.. Exploratien and Development ..

Production Size Small

Page 1 
Developent Status Little Develcped Producer, Inactive

-. Description ol Workings -.

Desc Workings Surface

- Relerence -

Reference

PHILLIPS, K.A., 1987, ARIZONA INDUSTRIAL MINERALS: ARIZONA DEFARTMENT OF MINES AND MINEEAL RESOURCES REPORT 4, 185 P.

Reference PEIRCE. H.W., 1990, ARIZONA GECLOGICAL SURVEY INDUSTRIAL MINERAL CARD FLLES.

$P \approx \cong 2$ 


\section{Mineral Resources Data System (MRDS)}

Report Title

Issue Date 00/00/00

Current Date Monday, April $i, 1997$

Current Time 10:24:50

Number 51 of 103

Printed 51 of 103

\begin{tabular}{|c|c|c|c|c|}
\hline Record Number & TC3849o & \multicolumn{2}{|c|}{ User Field } & $\cdot 93,6$ \\
\hline Record Type & Site & \multicolumn{2}{|c|}{ Flle Link 10} & CIMRI, IMS \\
\hline Reporter & ORFIS, GRETA J. & & & \\
\hline Reporter Affiliation & Uses & \multirow{2}{*}{\multicolumn{2}{|c|}{ Repcr Date }} & 9304 \\
\hline \multirow[t]{2}{*}{ Site Name } & TUAKEY HILLS CINOER PIT & & & \\
\hline & -- Locstion Information -- & \multirow{2}{*}{\multicolumn{2}{|c|}{ Country Code }} & \\
\hline Country & UNITED STATES & & & US \\
\hline State & ARIZONA & \multirow{2}{*}{\multicolumn{2}{|c|}{ Staie Code }} & $A Z$ \\
\hline County & COCONINO & & & \\
\hline Physiographic Prov & 11 CCLOFADO PLATEAU & & & \\
\hline Drainage Area & 15 LOWER COLORADO & & & \\
\hline Land Status & 41 & & & \\
\hline Administrative Area & COCONINO NATIONAL FOREST & & & \\
\hline Quad 250k & FLAGSTAF= & & & \\
\hline Quad 100k & FLACSTAR: & & & \\
\hline Quad 24k & FLAGSTAR: EAST (1983) & & & \\
\hline Elevation & $7420 \mathrm{Fi}$ & & & \\
\hline Latitude & $35 \cdot 13 \cdot 47 N$ & \multicolumn{2}{|c|}{ Desimal Lat } & 35.22972 \\
\hline Longitude & $111-30 \cdot \div 2 W$ & \multicolumn{2}{|c|}{ Decimai Long } & -111.51166 \\
\hline Accuracy & $A C C$ & & & \\
\hline Section & Section Fraction & Township & Range & Meridian \\
\hline 2 & NW OF SE & $2 \pi N$ & OOBE & GILA AND SALT RIVER \\
\hline Position & AEOUT $:$ :II ENE OF FLAGSTAFF. & & & \\
\hline \multirow[t]{2}{*}{ Losation Comments } & ON SE FEAK OF TURKEY HILLS. & & & \\
\hline & .. Commedity Information .- & & & \\
\hline Commodity Type & Non-metallic & & & . \\
\hline Commodities & VOL & & & \\
\hline Major & VOL & & & \\
\hline \multirow[t]{4}{*}{ Ore Materials } & CINDER & & & \\
\hline & -- Geclogy - & & & \\
\hline & -- Deposii Description .. & & & \\
\hline & --Individual Ore Bodies-- & & & \\
\hline Deposit Type & VOLCANIC & & & \\
\hline
\end{tabular}

Page 1 
Production Size Small

Developent Status Little Developed Producer, Inactive

-- Description of Workings --

Desc Workings Surface

- Reference -

Reference

PHILLIPS, K.A., 1987, ARIZONA INDUSTRIAL MINERALS: ARIZONA DEPARTMENT OF MINES AND MINERAL RESOUFCES REPORT 4, 185 P.

Reference PEIRCE, H.W., 1990, ARIZONA GEOLOGICAL SURVEY INDUSTRIAL MINERAL CARD FILE.

Page 2 


\section{Mineral Resources Data System (MRDS)}

Report Title

Issue Date 00/00/00

Current Date Monday, April 7, 1997

Current Time 10:24:50

Number 52 of 103

Record Number

TC36898

Record Type

Site

User Field

File Linik 10

-93/6

Repcrter

ORFIS, GFETA J.

Recorter Affiliation

USGS

Report Date

CIMRI, IMIS

Site Name

STAR NO. 23 CINDEA PIT

-- Locailon iniormation .-

Country

UNITED STATES

Country Code

US

State

ARIZONA

State Code

$A Z$

County

COCONINO

Physiographic Prov 11 COLORADO PLATEAU

Drairage Area 15 LOWEÁ COLORADO

Land Status $\quad 41$

Administrative Area COCCNINC NATIONAL FOREST

Quad 250K FLAGSTAFF

Quad iook FLAGSTAF=

Quad $24 k$

WING NVIC:NTAN (1974)

Elevation

$7580=T$

Latitude

$35 \cdot 16 \cdot 18 \mathrm{~N}$

Longitude

$111 \cdot 46 \cdot 18 \mathrm{~W}$

Decimal Lat

35.27166

Acsuracy

$A C C$

Decimal Long

$.111 .771 \varepsilon \hat{\varepsilon}$

$\begin{array}{lllll}\text { Section } & \text { Section Fraction } & \text { Township } & \text { Range } & \text { Meridian } \\ 20 & \text { NE OF SW } & 22 \mathrm{~N} & \text { O06E } & \text { GILA ANC SALT RIVEA }\end{array}$

Location Comments ON EASTEFN FLANK OF WING MIC'SNTAIN.

-. Commodity Information ..

Commodity Type Non-metailic

Commodities

VOL

Major

VOL

Ore Materials

CINDEP

- Geology ..

- Deposit Description ..

--Individual Ore Bodies--

Deposit Type VOLCANIC

.. Explcration and Development ..

Production Size

Smal! 
Developent Status Little Developed Producer, Inactive

-- Description of Workings -.

Desc Workings Suriace

- Reference -

Reference

PHILLIPS. K.A., 1987, ARIZONA INCUSTRIAL MINERALS: ARIZONA DEPARTMENT OF MINES AND MINEFAL RESOURCES REPORT NO. 4, 185 P.

Reference PEIRCE, H.W., 1990, ARIZONA GEOLOGICAL SURVEY INDUSTRIAL MINERAL CARD FILES.

Page 2 


\section{Mineral Resources Data System (MRDS)}

Report Title

Issue Date 00/00/00

Current Date Monday, April 7, 1997

Number 53 of 103

Recsrd Number

TC38499

Recsrd Type

Site

File Link 10

-93/6

Reporter

ORRIS. GRETA J.

Reporter Affiliation

USGS

Site Name

SPIT SPRING CINDER PIT

Report Date. $\quad 9304$

-. Location Information -

Country

UNITED STATES

Country Code

US

Staie

ARIZCNA

State Code

$A Z$

County

COCONINO

Physiographic Prov 11 COLORADO PLATEAU

Drainage Area 15 LOWEF COLORADO

Lard Status

41

Aciministrative Area KAIBAB NATIONAL FOREST

QuEJ 250k

FLAGSTAFF

Qued 100k

FLAGSIAFF

Q: $\approx 24 k$

PARKS (1980)

Elevation

$7100 \mathrm{FT}$

Latitude

$35 \cdot 15 \cdot 57 \mathrm{~N}$

Decinal Lat

35.26583

Longitude

$111.58 \cdot 10 \mathrm{~W}$

Decimal Long

.111 .96944

Accuracy

$A C C$

Section Section Fraction

21

S2 OF SE

Township Range

Meridian

$22 \mathrm{~N}$

OO4E

GILA AND SAIT RIVER

Pcsition

ABOUT $: .25$ AN WNW OF PARKS.

Lccation Comments AEOUT 0.4 MIN NNE OF SPITZ SFF:NG

.. Commodity intormation -.

Commodity Type Non-metallic

Commodities VOL

Major VOL

Ore Materials CINDER

- Geology ..

-- Deposit Description ..

--Individual Ore Bodies.-

Deposit Type VOLCANIC

.. Exploration and Development ..

Page 1 


\begin{tabular}{|c|c|}
\hline Record Number & (.....Continued) \\
\hline Production Size & Small \\
\hline Developent Status & Little Developed Producer, Inactive \\
\hline & - Description of Workings -- \\
\hline Desc Workings & Surface \\
\hline & - Reierence -- \\
\hline Reference & $\begin{array}{l}\text { PHILLIPS. K.A., 1987, ARIZONA INOUSTRIAL MINERALS: ARIZONA DEPARTMENT OF MINES AND MINEPAL } \\
\text { RESOURCES REPORT 4, } 185 \text { P. }\end{array}$ \\
\hline Reference & PEIRCE, H.W., 1990, ARIZONA GECLOGICAL SURVEY INDUSTRIAL MINERAL CARD FILES. \\
\hline
\end{tabular}

Page 2

$B-103$ 


\section{Mineral Resources Data System (MRDS)}

Report Title

Issue Date 00/00/00

Current Date Monday, April i, 1997

Current Time 10:24:50

Number 54 of 103

Printed 54 of 103

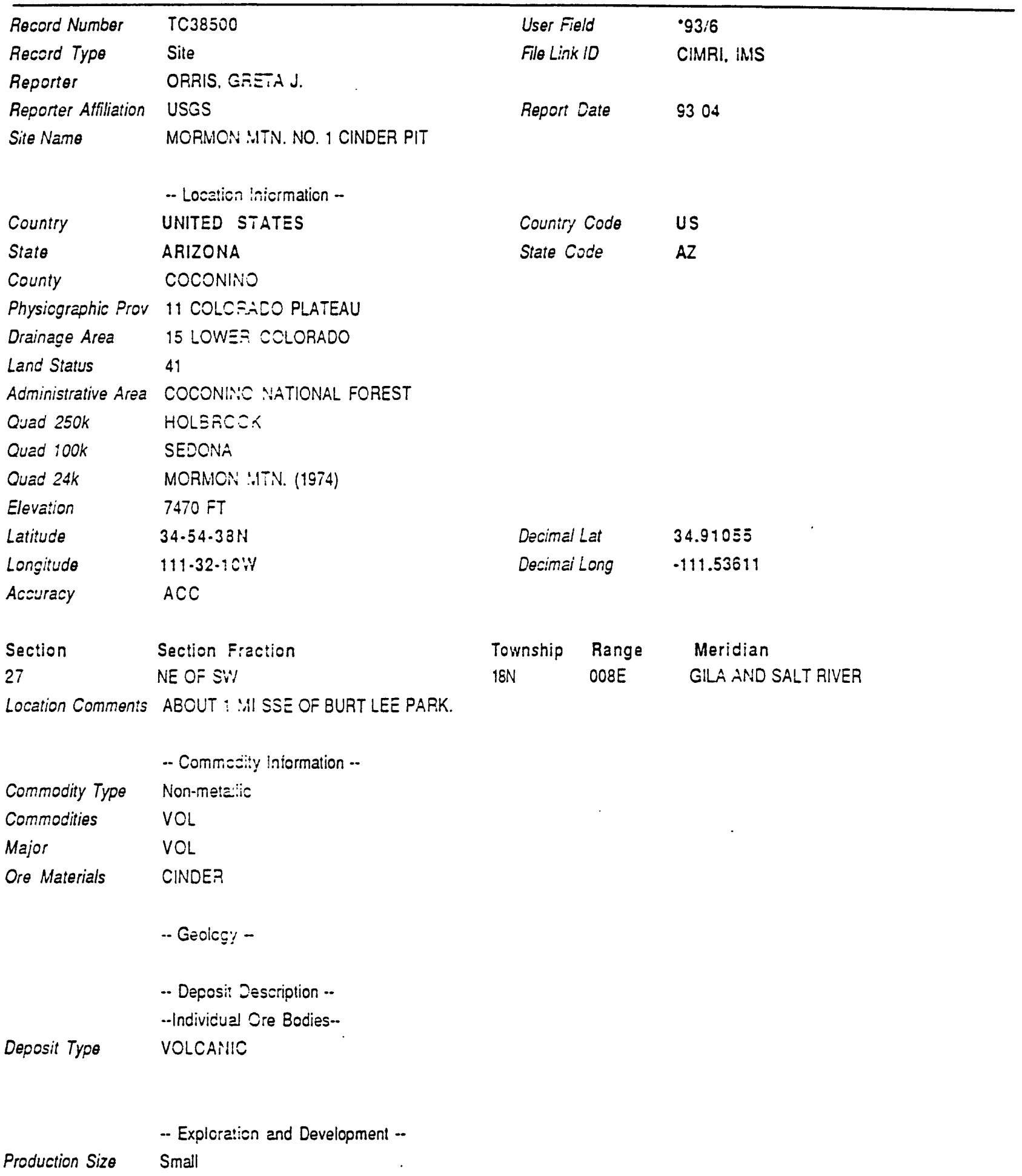


Developent Status Little Developed Producer, Inactive

Desc Workings

- Description ol Workings --

Surface

- Reference -

Reference

PHILLIPS, K.A., 1987, ARIZONA INCUSTRIAL MINERALS: ARIZONA DEPARTMIENT OF MINES AND MINESAL RESOURCES REPORT 4, 185 P.

Reierence PEIRCE, H.W., 1990, ARIZONA GEOLOGICAL SURVEY INDUSTRIAL MINERAL CAF.D FILE.

Page 2 


\section{Mineral Resources Data System (MRDS)}

Report Title

Issue Date 00/00/00

Current Date Monday, April T, 1997

Number 55 of 103

Record Number

TC38469

User Field

File Lirix 10

CIMRI, IMS

Record Type

Site

ORRIS, GREETA J.

Reporter Affiliation USGS

Repor: Date

9304

Site Name

LARRY'S STORE

- Lccaticn Inicrmation -

Country

UNITED STATES

Couniry Code

US

State

ARIZONA

State Coce

AZ

County

COCONINO

Physiographic Prov

11 COLORADO PLATEAU

Drainage Area

15 LOWEP COLORADO

Land Status

41

Administrative Area

COCONINO NATIONAL FOREST

Quad 250k

FLAGSTAFF

Quad 100k

FLAGSTAFF

Quad 24k

WING MCUNTAIN (1974)

Elevation

$7630 \mathrm{FT}$

Latitude

$35 \cdot 17 \cdot 10 \mathrm{~N}$

Decima' '-at

35.28611

Longitude

$111-46-21 \mathrm{~W}$

Decirt: I Long

.111 .7725

Accuracy

ACO

Section

Section Fraction

Township

Range

Meridian

17

SE OF SE

$22 \mathrm{~N}$

OO6E

GILA AND SALT RIVER

Location Comments ON THE NE FLANK OF WING MOUNTAIN. THERE AF. 17. THE LAT-LONG IS FOR THE NCRTHERNMOST P:T. THE SECOND PIT IS ABOUT 0.15 MI SSW OF T:-E FIRST.

-. Commodity Information..

Commodity Type Non-metallic

Commodities

VOL

Major

$\mathrm{VOL}$

Ore Materials

CINDER

.. Geology ..

-- Deposit Description .-

--Individual Ore Bodies-

Deposit Type VOLCANIC 
- Exploration and Development .-

Production Size Small

Developent Status Little Developed Producer, Inactive

- Description of Workings .-

Desc Workings Surface

-. Relerence -

Reference

PHILLIFS, K.A., 1987, ARIZONA INCUSTRIAL MINERALS: ARIZONA DEPARTMENT OF MINES AND MINEFAL RESOURCES REPORT 4, 185 P.

Reference

PEIRCE, H.W., 1990, ARIZONA GECLOGICAL SURVEY INDUSTRIAL MINERAL CARD FILES.

Page 2 


\section{Mineral Resources Data System (MRDS)}

Report Title

Issue Date 00100/00

Current Date Monday. April i, 1997

Current Time 10:24:50

Number 56 of 103

Printed 56 of 103

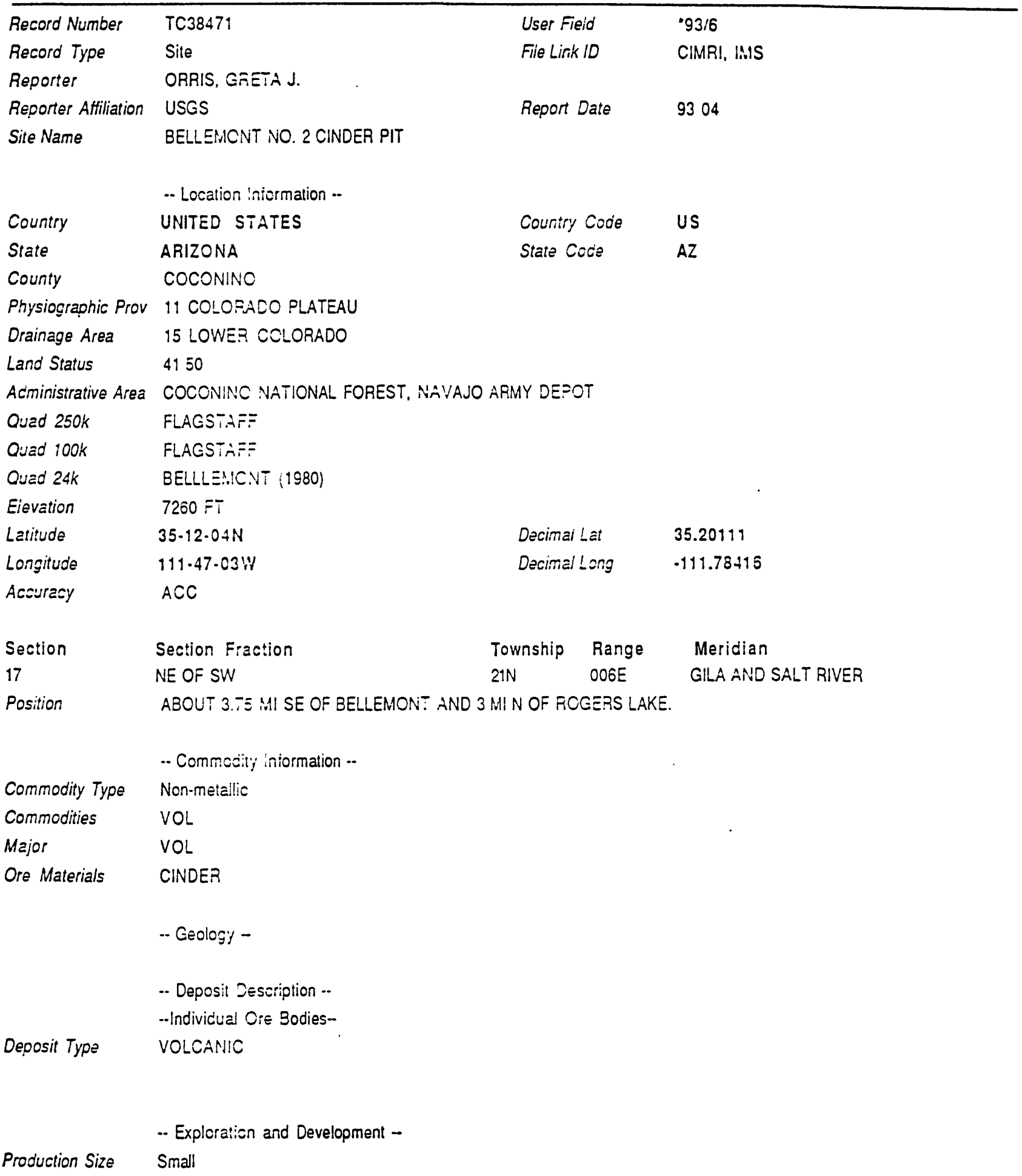


$\begin{array}{ll}\text { Dese Workings } & \text { - Description of Workings -. }\end{array}$

Reference

- Reference -

Reference

PHILLIPS. K.A., 1987, ARIZONA INCUSTRIAL MINERALS: ARIZONA DEPARTMENT OF MINES AND MINEFAL RESOURCES REPORT 4, 185 P.

PEIRCE. H.W., 1990. ARIZONA GECLOGICAL SURVEY INDUSTRIAL MINERAL CARD FILES.

Page 2 


\section{Mineral Resources Data System (MRDS)}

Report Title

Issue Date 00/00/00

Current Date Monday, April $;, 1997$

Current Time 10:24:50

Number 57 of 103

Printed 57 of 103

Record Number
Record Type
Reporter
Reporter Affiliation
Site Name
Country
State
County
Physiographic Prov
Drainage Area
Land Status
Acministrative Area
Quad 250k
Ouad iook
Ouazi $24 k$
Eievation
Latitude
Longitude
Acsuracy
Section
28
Position

TC384i2

Site

ORRIS, GRETA J.

USGS

ANGELL NO. 2 CINDER PIT

User Field

$\cdot 93 / 6$

File Link $1 D$

CIMRI, IMS

Report Date

9304

-. Location information --

UNITED STATES

Country Code

US

ARIZONA

State Code

AZ

COCONINO

11 COLOFADO PLATEAU

15 LOWER COLORADO

41

COCONINC NATIONAL FOREST

FLAGSTAF=

FLAGSTARE

ANGE:- (19E3)

60SO FT

$35-10.49 \mathrm{~N}$

Decirial Lat

35.18027

$111 \cdot 20 \cdot 20 \mathrm{i}$

Decimal Long

.111 .33888

$A C C$

Section Fraction

SE OF NW

ABOU: 2.2 :II WSW OF ANGELL.

$\begin{array}{lll}\text { Township } & \text { Range } & \text { Meridian } \\ 21 \mathrm{~N} & \text { O10E } & \text { GLA AND SALT RIVER }\end{array}$

-. Commodity Information ..

Commodity Type Non-metallic

Commodities VOL

Major VOL

Ore Materials CINDEA

-- Geology -

- Deposit Cescription..

--individual Ore Bodies--

Deposit Type VOLCANIC

-- Explcraticn and Development -.

Production Size Small 
Developent Status Little Develcped Producer, Inactive

Desc Workings Surface

- Descripticn of Workings ..

- Reference -

Reference

PHILLIPS, K.A., 1987, ARIZONA INCUSTRIAL MINERALS: ARIZONA DEPARTMENT OF MINES AND MINESAL RESOURCES REPORT 4, 185 P.

Reference PEIRCE, H.W., 1990, ARIZONA GECLOGICAL SURVEY INDUSTRIAL MINERAL CARD FILES.

Page 2 


\section{Mineral Resources Data System (MRDS)}

Report Title

Issue Date 00/00/00

Current Date Monday, April 7. 1997

Current Time 10:24:50

Number 58 of 103

Printed 58 of 103

\begin{tabular}{|c|c|c|c|c|}
\hline Record Number & TC38473 & \multicolumn{2}{|c|}{ User Field } & $.93 / 6$ \\
\hline Record Type & Site & \multicolumn{2}{|c|}{ File Link 10} & CIMRI, IMS \\
\hline Reporter & ORRIS, GREIA J. & & & \\
\hline Reporter Affiliation & USGS & \multicolumn{2}{|c|}{ Report Date } & 9304 \\
\hline Site Name & $\begin{array}{l}\text { ANGELL NO. } 1 \text { CINDER PIT } \\
\text {.- Location Inicrmation -- }\end{array}$ & & & \\
\hline Cousitry & UNITED STATES & \multicolumn{2}{|c|}{ Country Code } & US \\
\hline State & ARIZONA & \multirow{2}{*}{\multicolumn{2}{|c|}{ State Code }} & $A Z$ \\
\hline County & COCONINO & & & \\
\hline Phiysiographic Prov & 11 COLORADO PLATEAU & & & \\
\hline Drainage Area & 15 LOWER COLORADO & & & \\
\hline Lanc Status & 41 & & & \\
\hline Acininistrative Area & COCONINO NATIONAL FOREST & & & \\
\hline Quad 250k & FLAGSTAFE & & & \\
\hline Quad 100k & FLAGSTAFF & & & \\
\hline ouad $24 k$ & ANGELL $(1983)$ & & & \\
\hline Eievation & $6100 \mathrm{FT}$ & & & \\
\hline Latitude & $35.09 .20 N$ & Decinal & Lat & 35.15555 \\
\hline Longitude & $111 \cdot 19 \cdot 20 \mathrm{~W}$ & Decimal & Long & .111 .32222 \\
\hline Acsuracy & $A C C$ & & & \\
\hline Section & Section Fraction & Township & Range & Meridian \\
\hline 3 & NW OF NE & $20 \mathrm{~N}$ & $010 E$ & GILA AND SALLT RIVER \\
\hline \multirow[t]{2}{*}{ Pcsition } & ABOUT 2.5 VI S OF ANGELL. & & & \\
\hline & -. Commodity Iniormation -- & & & - \\
\hline Commodity Type & Non-metaliic & & & \\
\hline Commodities & VOL & & & . \\
\hline Major & VOL & & & \\
\hline \multirow[t]{4}{*}{ Ore Materials } & CINDER & & & \\
\hline & -- Geology -- & & & \\
\hline & .. Deposit Description .. & & & \\
\hline & --Individual Ore Bodies-- & & & \\
\hline \multirow[t]{2}{*}{ Deposit Type } & VOLCANIC & & & \\
\hline & $\begin{array}{l}\text {.- Exploration and Development .. } \\
\text { Small }\end{array}$ & & & \\
\hline
\end{tabular}


Developent Status Little Developed Producer, Inactive

- Description of Workings --

Desc Workings Surface

- Reference -

Reference PHILLIPS, K.A., 1987, ARIZONA INCUSTRIAL MINERALS: ARIZONA DEPARTMENT OF MINES AND MINESAL RESOURCES REPORT 4, 185 P.

Reierence PEIRCE, H.W., 1990, ARIZONA GECIOGICAL SURVEY INDUSTRIAL MINERAL CARD FILES.

$$
P \equiv \fallingdotseq \equiv 2
$$




\section{Mineral Resources Data System (MRDS)}

Report Title

Issue Date 00/00/00

Current Date Monday, April $\bar{i}, 1997$

Current Time 10:24:50

Number 59 of 103

Printed 59 of 103

\begin{tabular}{|c|c|c|c|c|}
\hline Record Number & TC38475 & \multicolumn{2}{|c|}{ User Field } & •93/6 \\
\hline Record Type & Site & \multicolumn{2}{|c|}{ File Link ID } & CIMR!. IMS \\
\hline Reporter & ORRIS, GFETA J. & & & \\
\hline Reporter Affiliation & USGS & \multicolumn{2}{|c|}{ Report Date } & 9304 \\
\hline \multirow[t]{2}{*}{ Site Name } & BAKER PIT & & & \\
\hline & -- Location intcrmation -- & & & \\
\hline Country & UNITED STATES & \multicolumn{2}{|c|}{ Country Code } & US \\
\hline State & ARIZONA & \multicolumn{2}{|c|}{ State Code } & $A Z$ \\
\hline County & COCONIAOO & & & \\
\hline Physiographic Prov & 11 CCLOEASO PLATEAU & & & \\
\hline Drainage Area & 15 LOWE: COLORADO & & & \\
\hline Land Status & 41 & & & \\
\hline Administrative Area & COCONINO NATIONAL FOREST & & & \\
\hline Quad $250 \mathrm{k}$ & FLAGSTAFF & & & \\
\hline Quad iook & FLAGST $\dot{R}==$ & & & \\
\hline Ouad $24 k$ & WINONA $(: \subseteq T)$ & & & \\
\hline Elevation & $6425 \mathrm{FT}$ & & & \\
\hline Latitude & $35-13.16 \mathrm{~N}$ & Decimal & Lat & 35.22111 \\
\hline Longitude & $111 \cdot 25 \cdot i 8 W$ & Decimai & Long & .111 .42166 \\
\hline Accuracy & $A C C$ & & & \\
\hline Section & Section Fraction & Township & Range & Meridian \\
\hline 10 & NE OF NE & $21 \mathrm{~N}$ & $009 E$ & GILA AND SALT RIVER \\
\hline Position & ABOUT $: . \equiv: 31$ NW OF WINONA. & & & \\
\hline \multirow[t]{2}{*}{ Location Comments } & ABOUT $1: \because 1$ W OF CINDER MOUNTAIN. & & & \\
\hline & -. Commodity information .. & & & \\
\hline Commodity Type & Non-metait: & & & . \\
\hline Commodities & VOL & & & \\
\hline Major & VOL & & & \\
\hline \multirow[t]{4}{*}{ Ore Materials } & CINDER & & & \\
\hline & .. Geology - & & & \\
\hline & .- Deposit Description.. & & & ${ }^{\circ}$ \\
\hline & -.Individual Ore Bodies-- & & & \\
\hline Deposit Type & VOLCAINIC & & & \\
\hline
\end{tabular}

Page 1 


\begin{tabular}{ll} 
Record Number & TC38475 $\quad$ (....Continued) \\
\hline $\begin{array}{l}\text { Production Size } \\
\text { Developent Status }\end{array}$ & Small \\
& Little Developed Producer, Inactive \\
& - Description of Workings -- \\
Desc Workings & Surlace \\
& - Reference - \\
Reference & PHILLIPS, K.A., 1987, ARIZONA INDUSTRIAL MINERALS: ARIZONA DEPARTMENT OF MINES AND MINESAL \\
Reference & PEIRCE, H.W., 1990, ARIZONA GEOLOGICAL SURVEY INDUSTRIAL MINERAL CARD FILES.
\end{tabular}




\section{Mineral Resources Data System (MRDS)}

Report Title

Issue Date 00/00/00

Current Date Monday, April $: 1997$

Number 60 of 103

Record Number TC35340

Record Type Site

Reporter

Reporter Affiliation

WELLS, TINA M.

Site Name

USGS

O'LEARY FEAK

-- Locaticn !nicrmation --

Country

State

UNITED STATES

ARIZONA

County COCONINO

Quad 250k

FLAGSTAFF

Quad 24k

Latitude

Longitude

Accuracy

UTM Northing

UTM Zore

OLEARY FEAK

35-24. $N$

111.31. W

EST

3917325 .

$+12$

Section

10

Section Fraction

-. Commcziliy Iniormalion ..

Commodity Type

Commodities

Non-metali:

Major

PUM

Ore Materials

PUM

PUMICE

.. Geology -

Host Rock Type RHYOLITIC VCLCANIC ROCKS

Host Rock Type Name

Age

RHYOLITIC VOLCANIC RCCKS

-- Deposit Cescription --

--Individual Ore Bodies--

Deposit Type

VOLCANIC

Deposit Desc Comm PUMICE IS RHYOLITIC.

-. Exploraiion and Development -.

Production Size

No

Developent Status Occurrence
Current Time 10:24:50

User Field "U94/1

File Linik 10

IMS, ClMRI

Report Date

9305

Printed 60 of 103

Country Code US

State Code AZ

$\begin{array}{ll}\text { Decimai Lat } & 35.4 \\ \text { Decimal Long } & \\ & \\ \text { UTM Easing } & 453082.5\end{array}$

$\begin{array}{lll}\text { Township } & \text { Range } & \text { Merician } \\ \text { 023N } & \text { OO8E } & \text { GILA AND SALT RIVER }\end{array}$

Host Rock Unit Name Age 
- Description of Workings .-

Desc Workings

Surface

- Reference -

Reference

PHILLIPS, K.A., 1987, ARIZONA INDUSTRIAL MINERALS: ARIZONA DEPARTMENT OF MINES AND M!NYEAAL RESOURCES MINERAL REPORT 4, 185 P.

Reference PEIRCE, H.W., 1990, ARIZONA GECLOGICAL SURVEY INDUSTRIAL MINERALS CARD FILE.

Page 2 


\section{Mineral Resources Data System (MRDS)}

Report Title

Issue Date 00/00100

Current Date Monday, April 7. 1997

Current Time 10:24:50

Number 62 of 103

Record Number

TC36493

User Field

Record Type Site

File Link 10

Printed 62 of 103

Reporter

ORRIS, GFETA J.

Reporter Affiliation USGS

Report Date 9304

Site Name NCRTH AND SOUTH SHEBA CRATERS

$\begin{array}{llll} & -- \text { Location Inicrmation - } & \\ \text { Country } & \text { UNITED STATES } & \text { Couniry Code } & \text { US } \\ \text { State } & \text { ARIZONA } & \text { State Cooje } & \text { AZ }\end{array}$

County COCONINO

Physiographic Prov 11 COLOFĩO PLATEAU

Drainage Area 15 LOWE: COLORADO

Land Status $\quad 30$

Quad 250k FLAGSTAF=

Quad 100k FLAGSTAE=

Ouad 24K MERRIAN OFITER (1989)

Longitude

$35 \cdot 18 \cdot 33 \mathrm{~N}$

Decimal Lat $\quad 35.30915$

Accuracy

$111 \cdot 15 \cdot 48 \%$

Decimal Long

.111 .26333

Section

$A C C+i-1: 11$

$7,8,17,18$

Section Fraction

Township Range

Meridian

Location Comments

$22 \mathrm{~N}$

O11E

GILA AND SALT RIVER

LAT-LONG IS FOR A POINT BETWEEN THE NORTH AND SOUTH SHEBA CRATERS. THIS POINT LIES IN THE CENTEA CF SECTION 7.

- Commocity Information -.

Commodity Type

Commodities VOL

Major VOL

Ore Materials CINDER

-. Geclogy -

-- Deposit Description --

--Individual Ore Bodies--

Deposit Type VOLCANIC

Deposit Desc Comm CINDER CCNES

-. Exploration and Development -.

Production Size

No 
Developent Status Occurrence

- Description of Workings ..

- Reference -

Reference PHILLIPS, K.A., 1987, ARIZONA INDUSTRIAL MINERALS: ARIZONA DEPARTMENT OF MINES AND MINIERAL RESOURCES REPORT 4, 185 P.

Page 2 


\section{Mineral Reșources Data System (MRDS)}

Report Title

Issue Date 00/00/00

Current Date Monday, April 7, 1997

Number 63 of 103

Current Date Monday, April 7. 1997

Record Number
Record Type

TC36494

Reporter

Sile

Reporter Affiliation

ORRIS, GRETA J.

Site Name

PARKS

Current Time $10: 24: 50$

Printed 63 of 103

User Fieid $\quad 93 / 6$

File Linik $10 \quad$ CIMRI, IMS

Repcr Date 9304

-. Location Information -

Country

UNITED STATES

Couniry' Code

US

State

ARIZONA

State Code

AZ

\section{County}

COCONINO

Physiographic Prov 11 COLORADO PLATEAU

Drainage Área 15 LOWER COLORADO

Land Status $\quad 41$

Administrative Area KAIBAB NATIONAL FOREST

Ouad 250k

FLAGSTAFF

Quad $100 k$

FLAGSTAFF

Quad 24k

PARKS (1980)

Elevation

7050 FT

Latitude

35-15.05N

Longitude

$111.57 \cdot 47 \mathrm{~W}$

Accuracy

ACC

Section

Section Fraction

27

Position

SW OF SW

ABOUT $1 \mathrm{MI}$ SW OF PARKS.

Deciri: Lat

35.25138

Decim:! Long

.111 .96305

-. Commodity Information --

Commodity Type

Non-metallic

Commodities

VOL

Major

VOL

Ore Materials

CINDER

-. Geology --

- Deposit Description --

--Individual Ore Bodies-

Deposit Type VOLCANIC

-. Exploration and Development -.

Production Size Small

$\begin{array}{lll}\text { Township } & \text { Range } & \text { Meridian } \\ 22 N & \text { O04E } & \text { GLA AND SALT RIVER }\end{array}$


Developent Status Little Developed Producer, Inactive

- Description of Workings --

Desc Workings Surface

- Reference -

Reference

PHILLIPS, K.A., 1987. ARIZONA INDUSTRIAL MINERALS: ARIZONA DEPARTMENT OF MINES AND MINE.RAL RESOURCES REPORT 4, 185 P.

Reference PEIRCE, H.W., 1990, ARIZONA GECLOGICAL SURVEY INDUSTRIAL MINERAL CARD FILES.

Page 2 


\section{Mineral Resources Data System (MRDS)}

Report Title

Issue Date 00/00/00

Current Date Monday, April T, 1997

Current Time 10:24:50

Number 64 of 103

Record Number

TC36911

User Field

Printed 64 of 103

Record Type

Site

Reporter

ORRIS, GRETA J.

Reporter Affiliation

USGS

Site Name

HUMPHFEYS PEAK NO. 1 CINDER PIT

File Link ID

$.93 / 6$

Report Date

CIMRI. IMS

-. Location information .-

Country

UNITED STATES

Country Code

US

State

ARIZONA

State Code

AZ

County

COCONINO

Physiograpinic Prov

Drainage Area

11 COLOFADO PLATEAU

Land Status

15 LOWEA COLORADO

Administrative Area

Quad 250k

41

Quad $100 k$

COCONINO NATIONAL FOREST

Quad 24k

FLAGSTAF=

FLAGSTAFF

HUMPHEEYS PEAK (1983)

Elevation

$8500 \mathrm{FT}$

Latitude

$35 \cdot 21 \cdot 56 \mathrm{~N}$

Longitude

$111.44 .5 \div W$

Decimai Lat

35.36555

Aceuracy

ACC

Decirrai Long

.111 .74833

\begin{tabular}{|c|c|c|c|c|}
\hline Section & Section Fraction & Township & Range & Meridian \\
\hline 22 & S2 OF N2 & $23 \mathrm{~N}$ & $006 E$ & GILA AND SALT RIVER \\
\hline
\end{tabular}

Location Comments THERE AFE 2 CINDER PITS IN Ni2 OF SECTION. LAT-LONG IS FOR WESTERNMOST PIT.

-. Commecity Iniormation --

Commodity Type

Non-me!a!ic

Commodities

VOL

Major

VOL

Ore Materials CINDER

-- Geology --

- Deposit Description -

--Individual Ore Bodies--

Deposit Type VOLCANIC

-. Exploration and Development -.

Production Size

Smail!

Page 1 
Developent Status Little Developed Producer, Inactive

-- Description of Workings .-

Desc Workings Surface

Roforence

- Reference -

PHILLIPS, K.A., 1987, ARIZONA INDUSTRIAL MINERALS: ARIZONA DEPART:YENT OF MINES AND MINESAL RESOURCES REPORT NO. 4, 185 P.

Reference PEIRCE, H.W., 1990, ARIZONA GEOLOGICAL SURVEY INDUSTRIAL MINERA! CAFD FILES.

Page 2 


\section{Mineral Resources Data System (MRDS)}

Report Title

Issue Date 00100/00

Current Date Monday, April 7. 1997

Current Time :0:24:50

Number 65 of 103

Record Number TC35343

Printed 65 of 103

Record Type Site

Reporter

WELLS, TINA M.

Reporter Affiliation USGS

Site Name ROBINSON CRATER AREA

User Fieid

SHE Name ROBINSON CRATER AREA

-- Lecation Inicrmation -

Country

State

County

Ouad 250k

Ouad 24k

Latitude

Longitude

Accuracy

UTM Northing

UTM Zone

Section

$4,9.10$

Section Fraction

UNITED STATES

ARIZONA

COCONINO

FLAGSTAFF

O'LEARY PEAK

35.24- $N$

111-33- W

EST

3917343.

$+12$

File Lisix 10

טU9/1

Repcri Dato 9305

IMS, CINAI

Courity Code US

State Esce

$A Z$

Decirimaj Lat

35.4

Decimai Long

.111 .55

UTM EEsting

450055.5

Township Range

Meridian

$023 \mathrm{~N}$

OOBE

GILA AND SALT RIVER

-- Commodity Information --

Commodity Type Non-metailic

Commodities PUM

Major PUM

Ore Materials PUMICE SAND

-. Geology -

-. Deposit Description .-

--Individual Ore Bodies-

Deposit Type VOLCAN!C?

Deposit Dese Comm PUMICE SAND.

-- Exploration and Development --

Production Size

U

Developent Status

Prospect, Inactive

-- Description of Workings ..

Page 1 
- Relerence -

Reference PHILLIPS, K.A., 1987, ARIZONA INDUSTRIAL MINERALS: ARIZONA DEPARTMENT OF MINES AND MINERAL RESOURCES MINERAL REPORT 4.185 P.

Reference PEIRCE, H.W., 1990, ARIZONA GECLCGICAL SURVEY INDUSTRIAL MINERALS CARD FILE.

Page 2 


\section{Mineral Resources Data System (MRDS)}

Report Title

Issue Date 00/00/00

Number 66 of 103

Current Date Monday, April T, is@7

Current Time 10:24:50

Printed 66 of 103

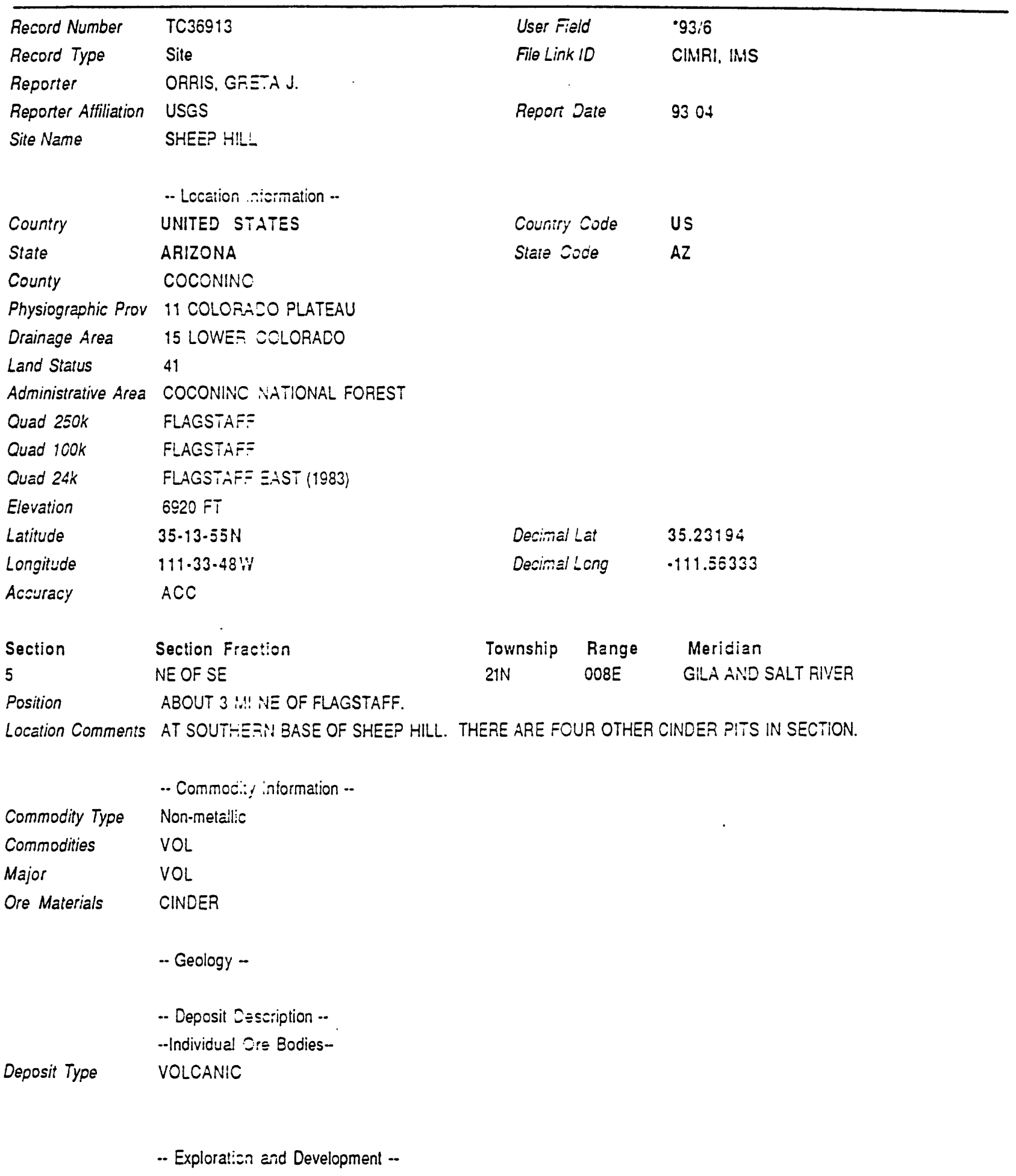


Record Number

Production Size

Developent Status TC36913

(....Continued)

Small

Little Develcped Producer, Inactive

- Description of Workings -

Desc Workings Surface

- Reference -

Reference

PHILLIPS, K.A., 1987, ARIZONA INDUSTRIAL MINERALS: ARIZONA DEPARTMENT OF MINES AND MINEPAL RESOURCES REPORT 4, 185 P.

Reference

Page 2 


\section{Mineral Resources Data System (MRDS)}

Report Title

Issue Date 00/00/00

Current Date Monday, April 7. 1997

Current Time 10:24:50

Number 67 of 103

Record Number TC36917

Record Type Site

File Linik ID CIMRI. IMS

Reporter

Reporter Affiliation

ORRIS, GRETA J.

Site Name

USGS

STAR NO. 29 CINDER PIT

Repor: Date

9304

-. Location !nicrmation -.

Country UNITED STATES

Courivy Code US

State

ARIZONA

State Code

AZ

County

COCONINO

Physiographic Prov 11 COLORACO PLATEAU

Drainage Area 15 LOWE. COLORADO

Land Status 41

Administrative Area COCONINO NATIONAL FOREST

Quad 250K FLAGSTAF:=

Quad 100k FLAGSTAFF

Quad 24k WING MOUNTAIN (1974)

Elevation $7560 \mathrm{FT}$

Latitude

$35 \cdot 16 \cdot 26 N$

Decirral Lat

35.27388

Longitude

$111.46 .07 \mathrm{~W}$

Decimấ Long

.111 .76861

Accuracy

ACC

Section

Section Fraction

Township Range

Meridian

21

NW OF SW

$22 \mathrm{~N}$

OO6E

GILA AND SALT RIVER

Location Comments AT EASTEPN BASE OF WING MOUNTAIN.

- Commodily intormation ..

Commodity Type Non-metallic

Commodities VOL

Major VOL

Ore Materials CINDER

-- Geology ..

-. Deposit Description -.

--Individual Ore Bodies-

Deposit Type VOLCANIC

Production Size

-- Explcraticn and Development -.

Small 
Developent Status Little Developed Producer, Inactive

- Description of Workings --

Desc Workings Surface

- Reference -

Reference PHILLIPS, K.A., 1987, ARIZONA INDUSTRIAL MINERALS: ARIZONA DEPARTMENT OF MINES AND MINEPAL RESOURCES REPORT NO. 4, 185 P.

Reference PEIRCE, H.W., 1990, ARIZONA GECLOGICAL SURVEY INDUSTRIAL MINERAL CARO FILES.

Pล̧⿻ 2 


\section{Mineral Resources Data System (MRDS)}

\section{Report Title}

Issue Date 00/00/00

Current Date Monday. April T, 1997

Current Time i0:24:50

Number 68 of 103

Record Number

TC30918
Site
ORRIS, GRETA
USGS

User Field

File Lirik 10

-U95i05

Record Type

Reporter

- Reporter Affiliation

USGS

Repcr Da:e

CIMRI, IMS

Editor Name

ORFIS, GRETA J.

Site Name

$\begin{array}{cl}\text { Type Affiliation } & \text { Date } \\ R \text { USGS } & \$ 11 ; 93\end{array}$

Comments

RED HILL PIT

- Location Intormation -

Country

UNITED STATES

Country Code US

State

ARIZONA

State Sode

AZ

County

COCONINO

Physiographic Prov

11 COLORADO FLATEAU

Drainage Area

15 LOWER COLORADO

Land Status

41

Administrative Area

COCONINO NATIONAL FOREST

Quad 250k

FLAGSTAFF

Quas 100k

FLAGSTAFF

Quad 24k

FLATSTAFF EAST (1983)

Eievation

$6880 \mathrm{FT}$

Latitude

35-13-20N

Longitude

$111.32 .52 \mathrm{~W}$

Decimal Lal

35.22222

Decimal long

Acsuracy

ACC

Section

Section Fraction

Township

Range

Meridian

9

NW OF NE

$021 \mathrm{~N}$

OOBE

GILA AND SALT RIVER

Printed 68 of 103

Position ABCUT $3 \mathrm{MI} \equiv$ OF FLAGSTAFF.

Location Comments ON THE SE FLANK OF WILDCAT HILL.

.. Commodity Information ..

Commodity Type Non-metalic

Commodities VOL

Major $\quad \mathrm{VOL}$

Ore Materials CINDER

Commod Subtypes

USED FOR TREATMENT OF ICY HIGHWAYS, ROAD EEDS. AND LANDSCAPING.

- Geology --

.. Deposit Description ..

-.-Individual Ore Bodies- 
Deposit Type VOLCANIC

\begin{tabular}{|c|c|}
\hline Production Size & $\begin{array}{l}\text { - Exploration and Development -- } \\
\text { Yes }\end{array}$ \\
\hline Developent Status & Developed Producet, Inactive \\
\hline Development MS & HYORCLOGOIC UNIT CO \\
\hline Desc Workings & $\begin{array}{l}\text { - Description of Workings -- } \\
\text { Surface }\end{array}$ \\
\hline & -- Reference - \\
\hline Reference & $\begin{array}{l}\text { PHILLIPS, K.A., 1987, ARIZONA INCLSTRIAL MINEPALS: ARIZONA DEPARTMENT OF MINES AND MINEFAL } \\
\text { RESOURCES REPORT 4, } 185 \text { P. }\end{array}$ \\
\hline Reference & PEIRCE, H.W., 1990, ARIZONA GECLCGICAL SURVEY INDUSTRIAL MINERAL CARD FILE. \\
\hline
\end{tabular}

Page 2 


\section{Mineral Resources Data System (MRDS)}

Report Title

Issue Date 00/00/00

Number 69 of 103

Current Date Monday, April -, 1997

Current Time :0:24:50

Printed 69 of 103

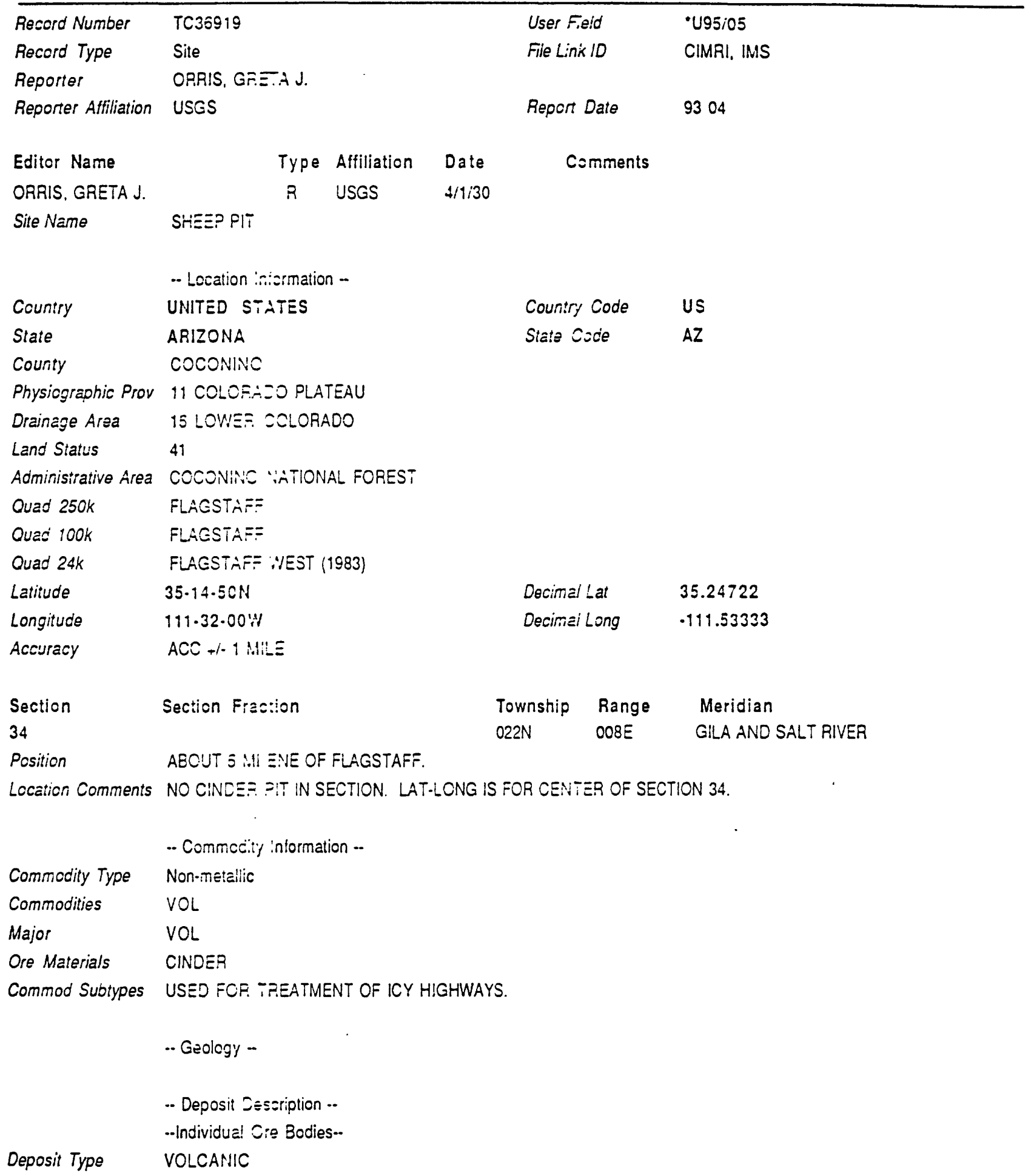

Page 1 
- Exploration and Development -.

Production Size

Developent Status

Development MS
Yes

Intermittent Producer

Mill i1s
HYDROLCGOIC UNIT CO

- Descripticn of Workings -.

Dese Workings Surface

-. Reierence -

Reference PHILLIPS. K.A., 1987, ARIZONA INDUSTRIAL MINEFA'_S: ARIZONA DEPARTMENT OF MIPIES AND MINE:AL RESOURCES REPORT 4, 185 P.

Reference PEIRCE, H.W., 19SO, ARIZONA GECLOGICAL SURVEY INDUSTRIAL MINERAL CARD FILE.

Page 2 


\section{Mineral Resources Data System (MRDS)}

Report Title

Issue Date 00/00/00

Current Date Monday, Acril $\bar{i}, 1997$

Current Time 10:24:50

Number 70 of 103

Printed 70 of 103

\begin{tabular}{|c|c|c|c|c|}
\hline Record Number & $T C 36520$ & \multicolumn{2}{|c|}{ User Field } & $\cdot 93 / 6$ \\
\hline Record Type & Site & \multicolumn{2}{|c|}{ File Link 10} & CIMRI, IMS \\
\hline Reporter & ORRIS, GREIAJ. & & & \\
\hline Reporter Affiliation & USGS & \multicolumn{2}{|c|}{ Report Date } & 9304 \\
\hline \multirow[t]{2}{*}{ Site Name } & HORSE TANK CINDER PIT & & & \\
\hline & -. Location Iniormation -- & \multirow{2}{*}{\multicolumn{2}{|c|}{ Couniry Code }} & \\
\hline Country & UNITED STATES & & & US \\
\hline State & ARIZONA & \multirow{2}{*}{\multicolumn{2}{|c|}{ State Code }} & $A Z$ \\
\hline County & COCONINO & & & \\
\hline Physiographic Prov & 11 COLOFADO PLATEAU & & & \\
\hline Drainage Area & 15 LOWEF COLORADO & & & \\
\hline Land Status & 41 & & & \\
\hline Administrative Area & KAIEAE NAT:ONAL FOREST & & & \\
\hline Quad 250k & FLAGS:AE= & & & \\
\hline Ouad 100k & CAMEAON & & & \\
\hline Quad $62.5 k$ & EBERT MCLNTAIN & & & \\
\hline Quad 24k & EBERT :IC'SNTAIN (1989) & & & \\
\hline Eievation & $6710 \mathrm{FT}$ & & & \\
\hline Latitude & $35.33 .35 N$ & \multicolumn{2}{|c|}{ Decimal Lat } & 35.55972 \\
\hline Longitude & $111.54 .07 \mathrm{~W}$ & \multicolumn{2}{|c|}{ Decimal Long } & -111.90194 \\
\hline Accuracy & $A C C$ & & & \\
\hline Section & Section Fraction & Township & Range & Meridian \\
\hline 7 & S2 OF S2 & $25 \mathrm{~N}$ & $005 E$ & GILA AND SALT FIVER \\
\hline \multirow[t]{2}{*}{ Location Comments } & ABOUT 2 :AI E OF ESERT MOUNTAIN. & & & \\
\hline & -. Commoci:y Information -- & & & \\
\hline Commodity Type & Non-metallie & & & . \\
\hline Commodities & VOL & & & \\
\hline Major & VOL & & & \\
\hline \multirow[t]{4}{*}{ Ore Materials } & CINDER & & & \\
\hline & -. Geclogy -- & & & \\
\hline & .- Depcsit Cミscription .. & & & \\
\hline & -.Individual Ore Bodies-- & & & \\
\hline Deposit Type & VOLCANIC & & & \\
\hline
\end{tabular}




\begin{tabular}{ll} 
Record Number & TC36920 $\quad$ (....Continued) \\
\hline $\begin{array}{l}\text { Production Size } \\
\text { Developent Status }\end{array}$ & $\begin{array}{l}\text { Small } \\
\text { Little Developed Producer, Inactive }\end{array}$ \\
& - Description of Workings - \\
Dese Workings & Surface \\
& - Reference - \\
Reierence & PHILLIPS, K.A., 1987, ARIZONA INDUSTRIAL MINEFALS: ARIZONA DEPARTMENT OF MINES AND MINESAL \\
& RESOURCES REPORT NO. 4, 185 P. \\
Reference & PEIRCE, H.W., 1990, ARIZONA GECLOGICAL SURVEY INDUSTRIAL MINERAL CARO FILES.
\end{tabular}

Page 2

$B-135$ 


\section{Mineral Resources Data System (MRDS)}

Report Title

Issue Date 00/00/00

Current Date Monday, April T, 1997

Current Time 10:24:50

Number 71 of 103

Printed 71 of 103

Record Number
Record Type
Reporter
Reporter Affiliation

TC36921

User Fi: Id

File Lin ID

-93/6

Site

ORRIS, GAETA J.

Site Name

USGS

Repor: Date

CIMRI, IMS

OLLEARY PEAKK NO. I CINDER PIT

-. Location Information --

Country

UNITED STATES

Country Code

US

State

ARIZONA

County

COCONINO

Physicgraphic Prov

11 COLCATACO PLATEAU

Drainage Area

15 LOWEA COLORADO

Land Status

41

Administrative Area

COCONINO NATIONAL FOREST

Quaci 250k

FLAGSTAFF

Quad :00k

FLAGSTARF

Quad 24k

OLLAFY FEAK (1פE3)

Elevation

$7180 \mathrm{FT}$

Latitude

$35-23.06 \mathrm{~N}$

State Sode

AZ

Longitude

$111 \cdot 34 \cdot 22: \mathrm{N}$

Deciriai Lat

35.385

Accuracy

ACC

Section

Section Fraction

Decimai Long

.111 .57277

17

N2 OF NW

Township Range

Meridian

Location Comments $1.1 .5 \mathrm{MI}$ iV $C=$ ROBiNSON MOUNTAIN.

$23 \mathrm{~N}$

OOBE

GILA AND SALT RIVER

-- Commedity Information --

Commodity Type

Non-metallic

Commodities VOL

Major

VOL

Ore Materials CINDER

.. Geolegy ..

.. Decosit Descripticn .-

--Indivicual Ore Bodies--

Deposit Type VOLCANIC

Production Size

-- Exploration and Development -.

Small 


Record Number TC36921 (....Continued)

Developent Status Little Developed Producer, Inactive

- Description of Workings -

Desc Workings Suriace

- Reference -

Referenco

PHILLIPS, K.A., 1987. ARIZONA INDUSTRIAL MINERALS: ARIZONA DEPARTMENT OF MINES AND MINE?AL RESOURCES REPORT NO. 4, 185 P.

Roference PEIRCE, H.W., 1990, ARIZONA GECLOGICAL SURVEY INDUSTRIAL MINERAL CAF.D FILES.

Page 2 


\section{Mineral Resources Data System (MRDS)}

Report Title

Issue Date 00100100

Current Date Monday, April 7. 1997

Number 72 of 103

Printed 72 of 103

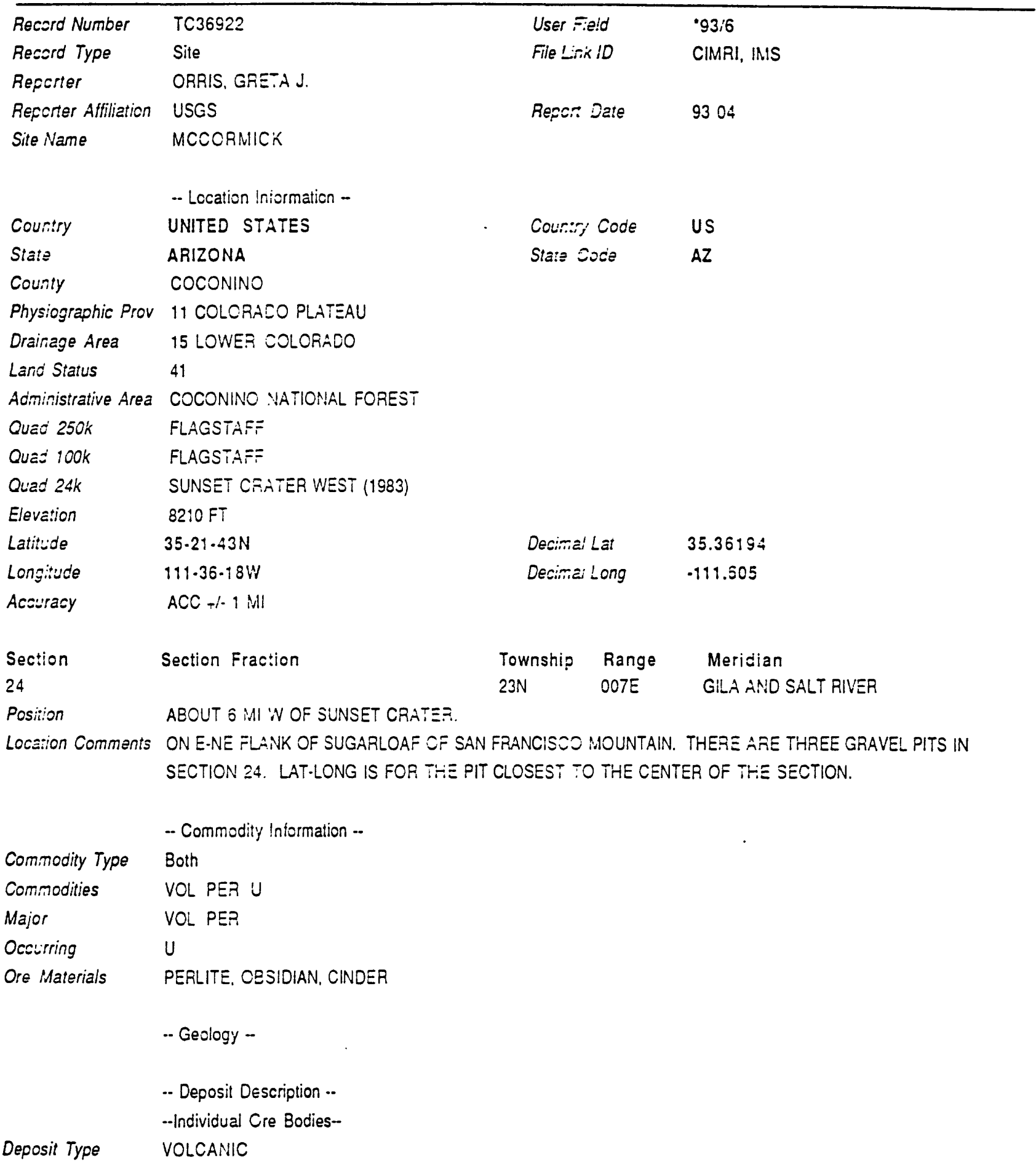


Deposit Desc Comm PERLITE WITH OBSIDIAN IN CINDER BED.

Production Size

- Exploration and Development No

Developent Status

Occurrence

- Description of Workings -

-- Reference -

Reference PHILLIPS. K.A., 1987, ARIZONA INDUSTRIAL MINEPÁ:S: ARIZONA DEPARTISENT OF MINES AND MINEPAL RESOURCES REPORT NO. 4,185 P.

Page 2 


\section{Mineral Resources Data System (MRDS)}

Report Title

Issue Date 00100100

Current Date Monday, April 7, 1997

Current Time 10:24:50

Number 73 of 103

Printed 73 of 103

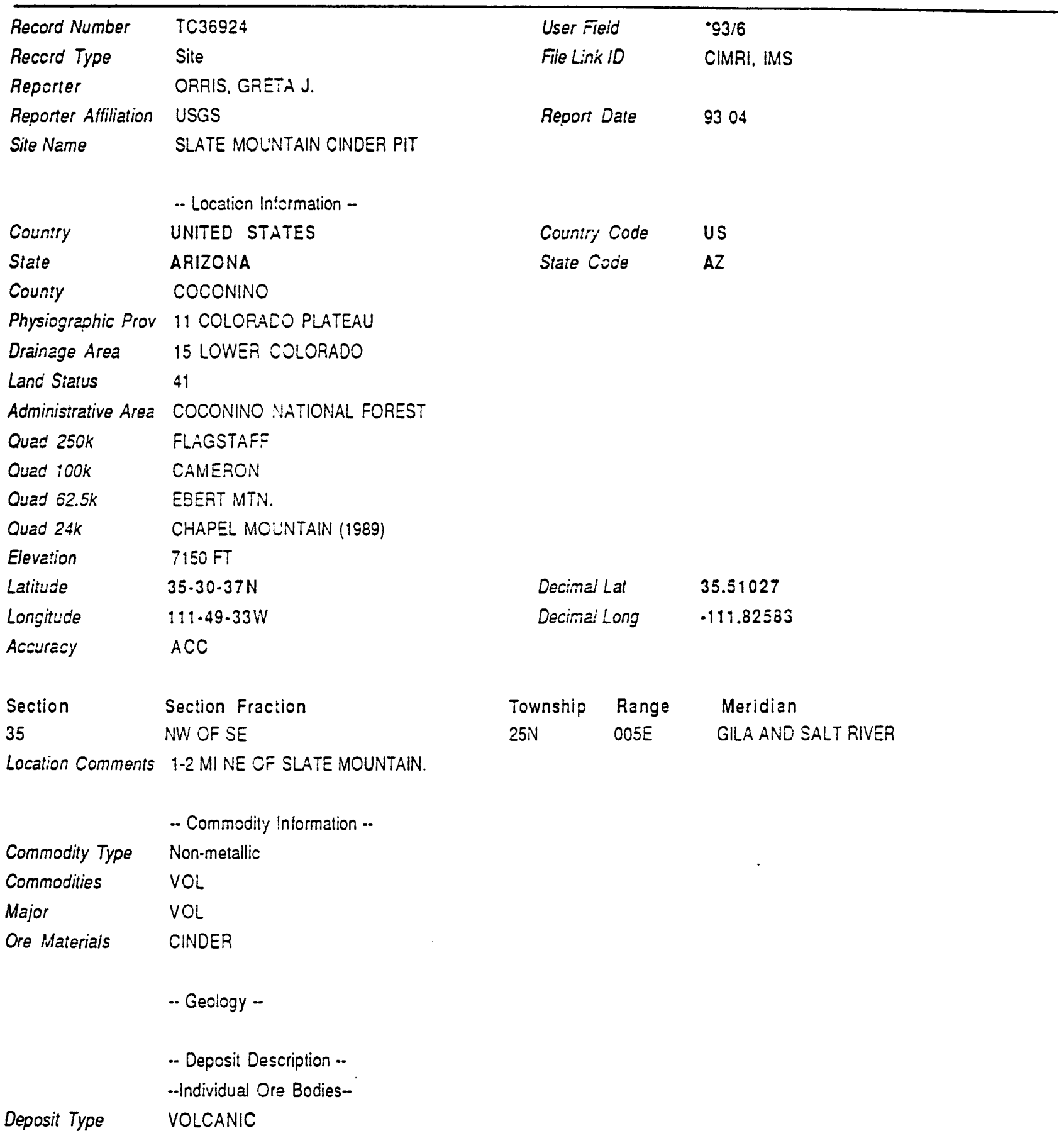

-. Exploration and Development .- 
Production Size

Small

Developent Status Little Developed Producer, Inactive

- Description of Workings -

Dese Workings Surface

- Reference .-

Reference

PHILLIPS, K.A., 1987, ARIZONA INCUSTRIAL MINERALS: ARIZONA DEPARTMENT OF MINES AND MINE:AL RESOURCES REPORT NO. 4, $185 P$

Reference PEIRCE, H.W., 1990, ARIZONA GEOLOGICAL SURVEY NDUSTRIAL MINERAL CARD FILES.

Page 2 


\section{Mineral Resources Data System (MRDS)}

Report Title

Issue Date 00/00/00

Current Date Monday, April i, 1997

\begin{tabular}{ll} 
Current Time 10:24:50 & $\begin{array}{l}\text { Number } 74 \text { of } 103 \\
\text { Printed } 74 \text { of } 103\end{array}$ \\
\hline $\begin{array}{l}\text { User Fieid } \\
\text { Fire Link ID }\end{array}$ & $\begin{array}{l}\cdot 93 / 6 \\
\text { CIMRI, IMS }\end{array}$ \\
Reperi Date & 9304 \\
& \\
& \\
Couriry Code & US \\
Staie Lode & AZ
\end{tabular}

Reccrd Number
Record Type
Reporter
Reporter Affiliation
Site Name
Country
State
County
Physiographic Prov
Drainage Area
Land Status
Administrative Area
Oud $250 k$

Ouad 250k

TC36925

Site

ORRIS, GFETA J.

USGS

CINDER STATION CINDER PIT

-. Location !nicrmation -

Quad 100k

UNITED STATES

ARIZONA

COCONINO

11 COLOFADO PLATEAU

Quad 24k

15 LOWEA CCLORADO

41

Eievation

COCONINO NATIONAL FOREST

FLAGSTARE

FLAGSTAF:

Latitude

FLAGSTAFF EAST (1983)

Longitude

$6940 \mathrm{FT}$

Accuracy

$35.07 .57 \mathrm{~N}$

$111 \cdot 37 \cdot 17 \mathrm{~W}$

Decirisel tat

35.1325

$\mathrm{ACC}$

Section

Section Fraction

11

SW OF NE

Position

ABOUT 4 :II S OF FLAGSTAFF.

-. Commosity !nformation -

Commodity Type

Non-meialic

Commodities

VOL

Major

VOL

Ore Materials

CINDER

.. Geology --

-- Deposir Description --

--Individual Ore Bodies--

Deposit Type

VOLCANIC

Production Size

-. Exploration ard Development -

Small

Page 1 
Developent Status Little Developed Producer, Inactive

Desc Workings

Reference

Reference
- Description of Workings -

Surface

- Reference -

PHILLIPS, K.A., 1987, ARIZONA INDUSTRIAL MINEPALLS: ARIZONA DEPARTMENT OF MINES AND MINEFAL RESOURCES REPORT 4, 185 P.

PEIRCE, H.W., 1990, ARIZONA GECLCGICAL SURVEY INDUSTRIAL MINERAL CARD FILE.

Page 2 


\section{Mineral Resources Data System (MRDS)}

Report Title

Issue Date 00/00/00

Current Date Monday, April 7, 1997

Current Time 10:24:50

Number 75 of 103

Printed 75 of 103

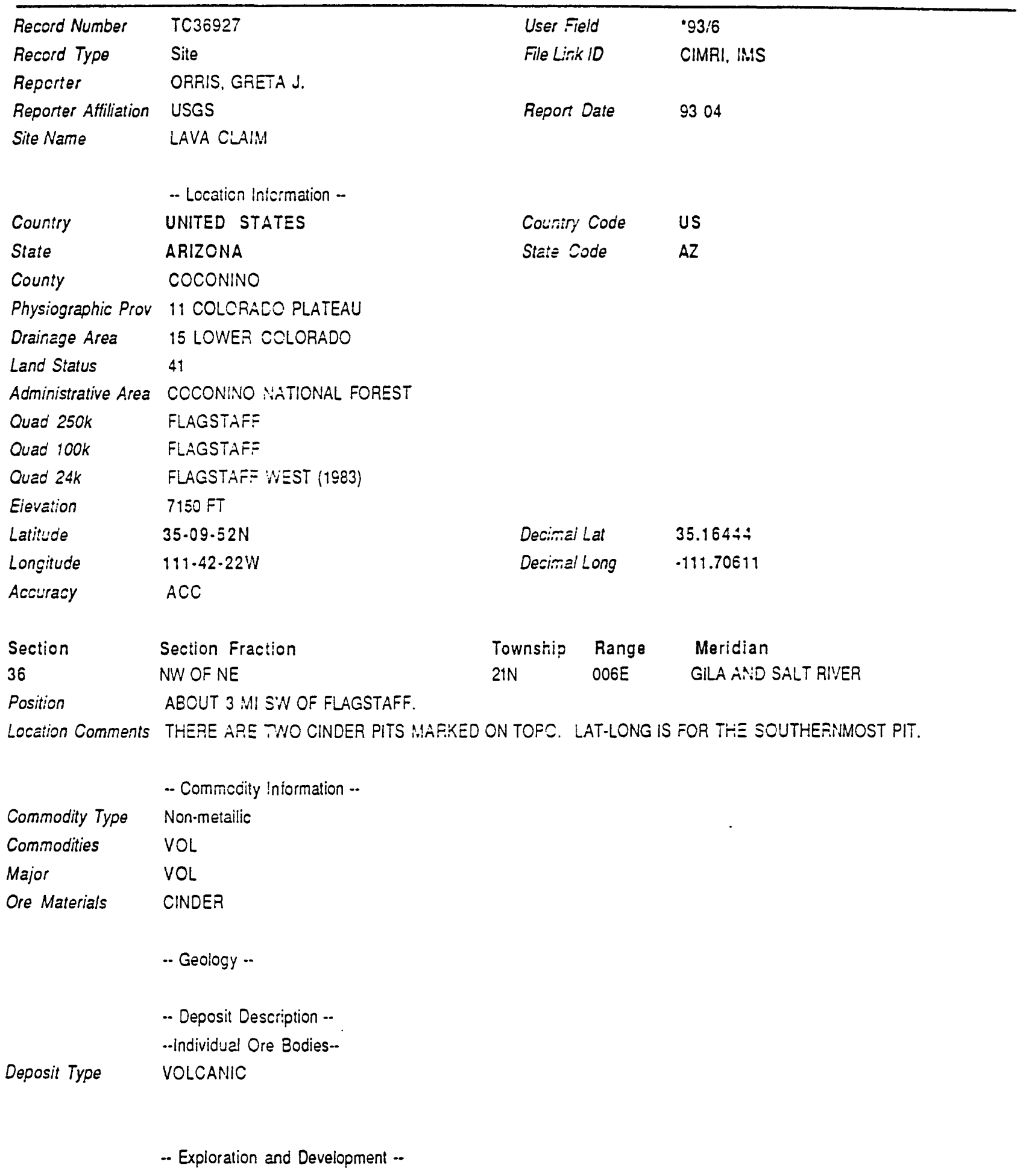

Page 1 
Production Size Small

Developent Status

Little Developed Producer, Inactive

- Description of Workings -

Desc Workings

$$
\text { Surface }
$$

- Relerence -

Reference PHILLIPS, K.A., 1987, ARIZONA INDUSTRIAL MINERALS: ARIZONA DEPARTMENT OF MINES AND MINEPAL RESOURCES REPORT 4,185 P.

Reference PEIRCE, H.W., 1990, ARIZONA GE:LLOGICAL SURVEY INDUSTRIAL MINERAL CAF.D FILE.

Page 2 


\section{Mineral Resources Data System (MRDS)}

Report Title

Issue Date 00/00/00

Current Date Monday, April 7. 1997

\begin{tabular}{|c|c|c|}
\hline Current Timie :0:24:50 & & $\begin{array}{l}\text { Number } 76 \text { of } 103 \\
\text { Printed } 76 \text { of } 103\end{array}$ \\
\hline Usar Fiend & "94/6 & \\
\hline File $L:-i x 1 D$ & CIMRI, IMS & \\
\hline Repc: Date & 9405 & \\
\hline Counisy Code & US & \\
\hline Sta:e Isode & $A Z$ & \\
\hline
\end{tabular}

$\begin{array}{ll}\text { Record Number } & \text { TCa } \\ \text { Record Type } & \text { Sile } \\ \text { Reporter } & \text { ORR }\end{array}$

Repcrier Atfiliation USGS

Site Name HUMPHREY PEAK NO.1

-- Location iniormation -

Country

UNITED STATES

State

ARIZONA

Ste:e Sade

$A Z$

County

COCONINO

Physicgraphic Prov 1

Lano Status $\quad 41$

Administrative Area CCCONINC NATIONÁL FOREST

Quad 250K FLAGSTAFF

Quad ioOK FLACSTAFF

Quad 24k

SUNISET CFATER WEST

Latituce

$35 \cdot 18-49 \mathrm{~N}$

Decin: 2 Lat

35.31361

Longitude

$111.37-33 \mathrm{~W}$

Deciri. $=1$ long

.111 .62583

Accuiacy

$A C C$

Section Section Fraction

02 ?

$\begin{array}{lll}\text { Townsnip } & \text { Range } & \text { Meridian } \\ \text { 022N } & \text { 002E } & \text { GiLA AND SALT RIVER }\end{array}$

-- Commodity Iniormation ..

Commodity Type

Non-metallic

Commodities

LST MEL

Majer

LST MBL

Ore Materials

LIMESTONE, MARELE

- Geology -.

Host Rock Type Name LIMESTONE, MAPBBLE

- Deposit Description .-.Individual Ora Bodies-

Deposit Type SEDIMENTARY

Deposit Dese COMm WHITE LIMESTONE AND MARBLE

-. Exploration and Development -.

Produztion Size

U
Host Rock Unit Name

REDWALI FM
Age

MISS 


\begin{tabular}{|c|c|}
\hline Record Number & (....Continued) \\
\hline Developent Status & Prospect, Inactive \\
\hline & - Description of Workings -- \\
\hline Desc Workings & Surface \\
\hline & - Relerence -- \\
\hline Reference & $\begin{array}{l}\text { PHILLIPS, K.A., 1987, ARIZONA INDUSTRIAL MINEPALS: ARIZONA DEPARTA.AENT OF MINES AND MINEPAL } \\
\text { RESOURCES REPORT 4, } 185 \text { P. }\end{array}$ \\
\hline
\end{tabular}

Page 2 


\section{Mineral Resources Data System (MRDS)}

\section{Report Title}

Issue Date 00/00/00

Current Date Monday, April T. 1997

Current Time 10:24:50

Record Number
Record Type
Reporter
Reporter Affiliation
Editor Name
ORAIS, GRETA J.
ORFIS, GRETA J.
Site Name

1008323

Site

ORRIS, GRETA J.

USGS

WINONA - SOUTH

User Fieid

File Lin'k 10

Repor: Date

Comments

$\begin{array}{cll}\text { Type } & \text { Affiliation } & \text { Date } \\ R & \text { USGS } & 1 / 1 / 94 \\ U & \text { USGS } & \Xi / 1 / 95\end{array}$

- Lccation Inicrmation -

Country

UNITED STATES

State

ARIZONA

County

COCONINO

Physiograchic Prov

Drainage Area 15

Land Status $\quad 41$

Administrative Area COCONINO NATIONAL FOREST

Quad 250k

FLAGSTAFF

Quad 24k

WINCNA

Latitude

Longitude

Acsirasy

$35-11-38 \mathrm{~N}$

$111 \cdot 24 \cdot 24 W$

$A C C$

Section

Section Fraction

23

-. Commodity Intormation -.

Commodity Type

Commodities

Non-metailic

Major

VOL

VOL

Ore Materials VOLCANIC CINDERS

-. Geology -

Host Rock Type Name

Age

VOLCANICS

-- Deposit Cescription -.

--Individual Ore Eodies-

Deposit Type VOLCANIC

$\begin{array}{ll}\text { Country Code } & \text { US } \\ \text { State Code } & \text { AZ }\end{array}$

$\begin{array}{ll}\text { Decimal Lat } & 35.19380 \\ \text { Decimai Long } & -111.40850\end{array}$

Township Range Meridian

O2IN OOSE GILA ÂID SALT RIVER

Page 1 
- Exploration and Development -.

Production Size Small

Developent Status Developed Producer, Inactive

- Descripticn of Workings -.

Desc Workings Surface

Workings Comments QUARRY.

- Relerence --

Reierence PHILLIPS, K..., 1987, ARIZONA INCUSTRIAL MINERALS: ARIZONA DEPARTMENT OF MINES AND MINEPAL RESOURCES MINERAL REPORT $4,185 \mathrm{P}$.

Info Source $94 / 07 / 20$

Pag 2 


\section{Mineral Resources Data System (MRDS)}

Report Title

Issue Date 00100100

Current Date Monday, April 7, 1997

Record Number

$1008 \div 59$

Record Type

Site

Reporter

ORRIS, GRETA J.

Reporter Affiliation

USES

Site Name

CINDER PIT

-. Location Iniormation -

Country

UNITED STATES

State

ARIZONA

COCONINO

Land Status

41

Administrative Area

Quad 250k

COCONINO NATIONAL FOREST

FLAGSTAFE

Quad 24k

FLACSTAFF WEST (1983)

Latitude

$35 \cdot 09 \cdot 42 \mathrm{~N}$

Longitude

$111 \cdot 43 \cdot 16 \mathrm{~W}$

Accuracy

ACC

Section

35

Section Fraction

NE

-. Commodity Iniormation -.

Commodity Type Non-metallic

Commodities $\mathrm{VOL}$

Major

VOL

Ore Materials VOLCANIIC CINDERS

-- Geciogy --

Host Rock Type VOICANICS

Host Rock Type Name

VOLCANICS

- Depcsit Description .-

--Incividual Ore Bodies.-

Deposit Type VOLCANIC

-- Explcration and Development -.

Production Size Small

Developent Status Little Developed Producer, Inactive
Current Time :0:24:50

User Field

File Link 10

• $94 / 3$

CIMRI, IMS

Report Date 9401

Couniny Code US

State Cooje AZ

$\begin{array}{ll}\text { Decim:i Lat } & 35.16160 \\ \text { Decim:i Long } & -111.72111\end{array}$

$\begin{array}{lll}\text { Township } & \text { Range } & \text { Meridian } \\ \text { O21N } & \text { O06E } & \text { GiLA AND SALT RIVER }\end{array}$

Printed 78 of 103 
Record Number $\quad 1008459$

(....Continued)

-- Description of Workings .-

Desc Workings

Surface

Reference

- Reference -

U.S. GEOLOGICAL SURVEY, 1983, FLAGSTAFF WEST 1:24,000 TOPOGRAFHIC QUADRANGLE.

Page 2

$8-|5|$ 


\section{Mineral Resources Data System (MRDS)}

Report Title

Issue Date 00/00/00

Current Date Monday, April i, 1997

Current Time 10:24:50

Nuniter 79 of 103

Reccrd Number 1008460

Recerd Type Site

Repcrter

ORRIS, GREIA J.

Reporter Affiliation USGS

Site Name

CINDER PITS

$\begin{array}{ll}\text { User Fizid } & \cdot 94 / 3 \\ \text { File } 1 \text { inin } 10 & \text { CIMRI, IMS }\end{array}$

Report 2ate 9401

- Location .niormation -.

Country UNITED STATES

Couriry Code US

State

ARIZONA

Sta:? Osce

AZ

County

COCONINC

Land Status

41

Adninistrative Area

COCONINC NATIONAL FOREST

Cued 250k

FLAGSTAF=

Quas $24 k$

FLAGSTAR= VVEST (1983)

Lativide

$35.09 .55 \mathrm{~N}$

Lorgitude

$111-42 \cdot 23: y$

Decima: Lat

35.16527

Acsuracy

$A C C$

Section

Section Fraction

36

NW OF NE

Decim: Long

.111 .70638

Location Comments 2ND PIT IS O.1 MILE S.

.. Commecity information -.

Commodity Type Non-metallic

Commodities VOL

Maior VOL

Ore Materials VOLCANic CINDERS

- Geolcgy -

Hos: Rock Type VOLCANICS

Host Rock Type Name

Age

Host Rock Unit Name

Age

Prinited 79 of 103

VOLCANICS

-. Deposit Lミscription -.

--Individual Ore Bodies-

Depcsit Type VOLCANIC

-. Exploration and Development ..

Produstion Size

Small

Deveiopent Status Little Develcped Producer, Inactive

Page 1 
Record Number 1008460

(....Continued)

- Description of Workings ..

Desc Workings

Reference
Surface

- Reference -

U.S. GECLOGICAL SURVEY, 1983, FLAGSTAFF WEST 1:24,C00 TOPOGRAFHIC OUADRANGLE.

Page 2

$B-153$ 


\section{Mineral Resources Data System (MRDS)}

Report Title

Issue Date 00/00/00

Current Time 10:24:50 Number 80 of 103

Current Date Monday, April 7, 1997

Current Time 10:24:50

Printed 80 of 103

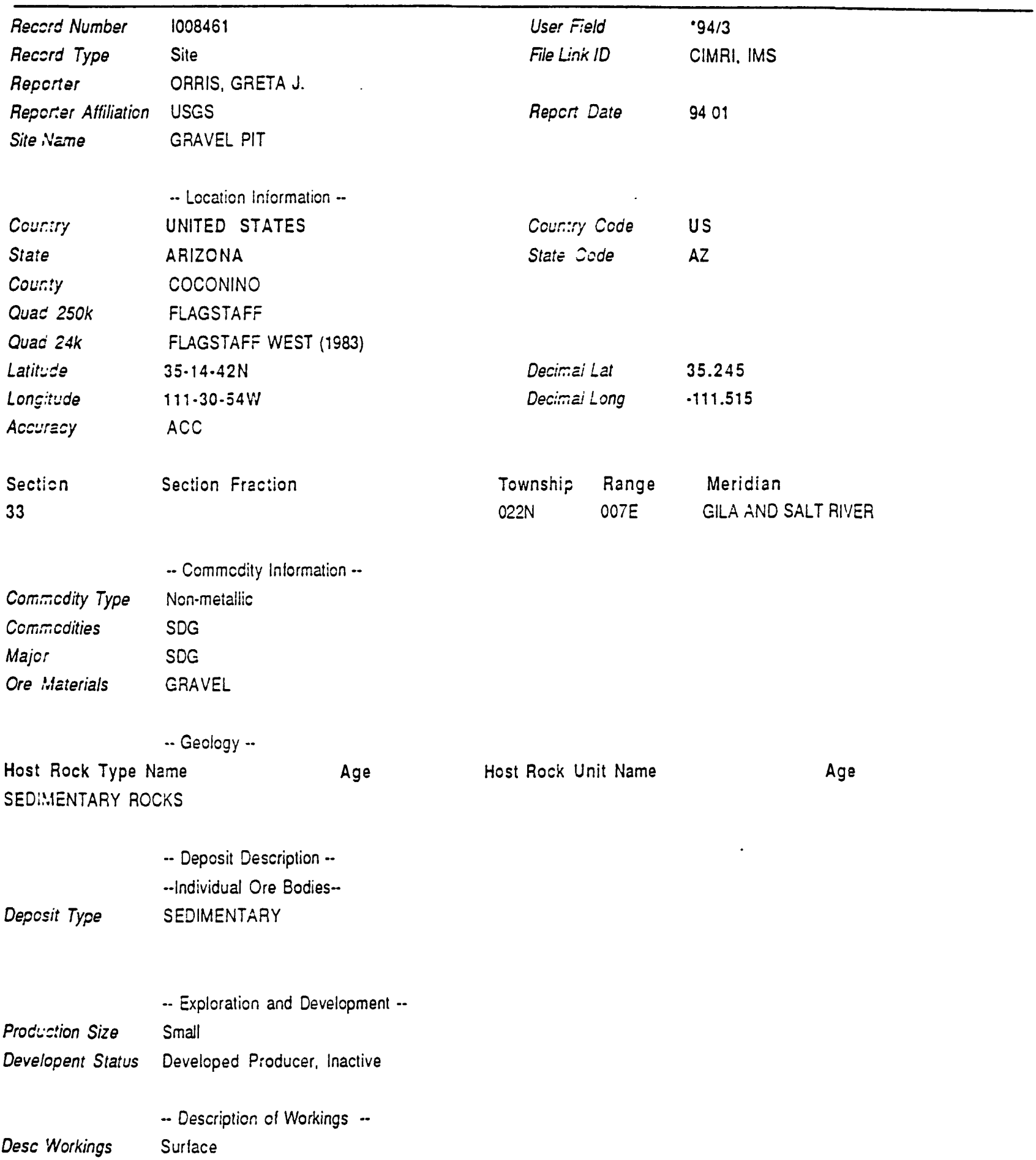


- Reference -

Reference U.S. GEOLCGICAL SURVEY, 1983, FLAGSTAFF WEST 1:24,000 TOPOGRAPHIC QUADRANGLE.

Page 2

$B-155$ 


\section{Mineral Resources Data System (MRDS)}

Report Title

Issue Date 00100,00

Current Date Monday, April T. 1997

\begin{tabular}{|c|c|}
\hline Record Number & 1008462 \\
\hline Record Type & Site \\
\hline Reporter & ORRIS, GRETA J. \\
\hline Reporter Affiliation & USGS \\
\hline \multirow[t]{2}{*}{ Site Name } & CINDER PIT \\
\hline & -. Location !nisimation -- \\
\hline Country & UNITED STATES \\
\hline State & ARIZONA \\
\hline County & COCONINC \\
\hline Quad 250k & FLAGSTAF= \\
\hline Quad 24k & FLAGSTAF: :VEST (1983) \\
\hline Latitude & $35 \cdot 10 \cdot 18 N$ \\
\hline Longitude & $111 \cdot 41 \cdot 57: 4$ \\
\hline Acsuracy & $A C C$ \\
\hline Section & Section Fraction \\
\hline \multirow[t]{2}{*}{30} & NW OF $\Sigma \equiv$ \\
\hline & - Commccitiy information .. \\
\hline Commodity Type & Non-metalis \\
\hline Commodities & VOL \\
\hline Major & VOL \\
\hline \multirow[t]{2}{*}{ Ore Materials } & VOLCANIC CINDERS \\
\hline & .. Geclogy -- \\
\hline Host Rock Type & VOLCANICS \\
\hline
\end{tabular}

Host Rock Type Name

Country Code

US

State Code

Number 81 of 103

Printed 81 of 103

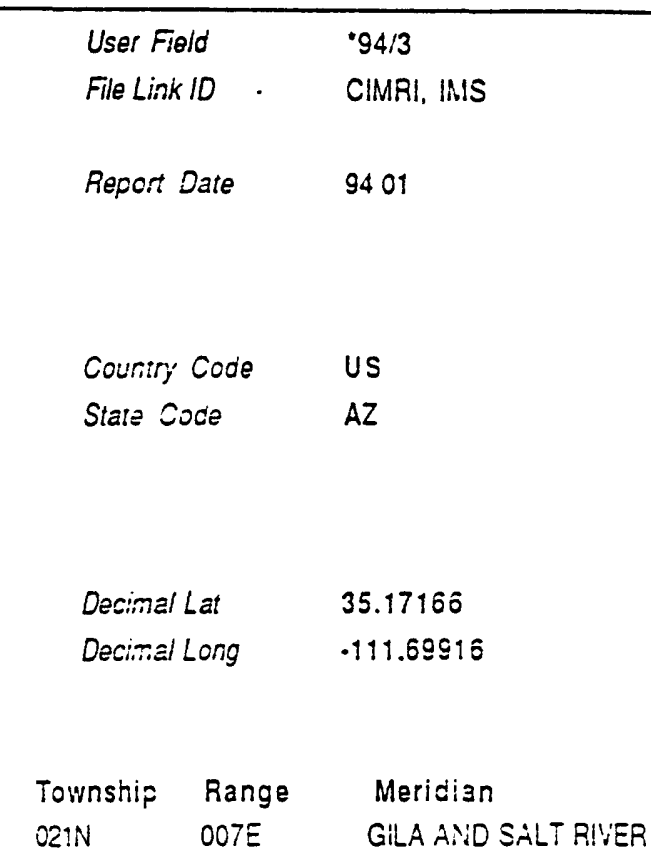

VOLCANICS

Host Rock Unit Name

Age

$\begin{array}{ll} & - \text { - Deposit Esscription -. } \\ & \text {--Indivicual Cre Eodies-- } \\ \text { Deposit Type } & \text { VOLCAN!IC }\end{array}$

-. Exploration and Development -.

Production Size

Small

Developent Status Little Develeped Producer, Inactive

-- Descripticn of Workings .-

Desc Workings Surlace 
- Reference -

Reference

U.S. GEOLOGICAL SURVEY, 1983. FLAGSTAFF WEST 1:24,000 TOPOGRAPHIC OUADRANGLE.

Page 2

$B-157$ 


\section{Mineral Resources Data System (MRDS)}

Report Title

Issue Date 00/00/00

Current Date Monday. April 7,1997

\begin{tabular}{|c|c|}
\hline Record Number & 1008463 \\
\hline Record Type & Site \\
\hline Reporter & ORRIS. GRETA J. \\
\hline Reporter Affiliation & USES \\
\hline \multirow[t]{2}{*}{ Site Name } & HAPPY IACK NO. 1 CINDE \\
\hline & -- Location 'niormation - \\
\hline Country & UNITED STATES \\
\hline State & ARIZONA \\
\hline County & COCONINO \\
\hline Land Status & 41 \\
\hline Administrative Area & COCONINO NATIONAL FO \\
\hline Quad 250k & HOLBROCK \\
\hline Quad 24k & HAPPY JACK (19G5; \\
\hline Latitude & $34 \cdot 44 \cdot 52 i$ \\
\hline Longitude & $111 \cdot 25 \cdot 17 \mathrm{~W}$ \\
\hline Accuracy & $A C C$ \\
\hline Section & Section Fraction \\
\hline \multirow[t]{2}{*}{29} & \\
\hline & -- Commediy Iniormation .- \\
\hline Commodity Type & Non-meta!lic \\
\hline Commodities & VOL \\
\hline Major & VOL \\
\hline \multirow[t]{2}{*}{ Ore Materials } & VOLCANYC CINDERS \\
\hline & .. Geology .. \\
\hline Host Rock Type & VOLCANICS \\
\hline
\end{tabular}

Host Rock Type Name

Current Time 10:24:50

Printed 82 of 103

VOLCANICS

User Fieid $\quad$ "94/3

File Link ID CIMRI, IMIS

Report Date 9401

Decimal Lat $\quad 34.74777$

Decimallong $\quad .111 .42138$

Township Range Meridian

016N OO9E GILAAND SALT RIVER

-- Depcsit Sescription -.

--Individual Ore Bodies-

Deposit Type VOLCANIC

-. Exploration and Development -.

Production Size

Smail

Developent Status Little Develcped Producer, Inactive

Page 1 
Record Number $\quad 1008463$

(....Continued)

-- Description of Workings .-

Desc Workings

Reference
Surface

- Reference -

U.S. GEOLCGICAL SURVEY, 1965. HAPPY JACK 1:24,000 TOPOGRAPHIC QUADFANGLE.

Page 2

$B-159$ 


\section{Mineral Resources Data System (MRDS)}

Report Title

Issue Date 00/00/00

Current Date Monday, April 7,1997

Current Time 10:24:50

Number 83 of 103

Printed 83 of 103

Record Number
Record Type
Reporter
Reporter Affiliation
Site Name
Country
State
County
Lano Status
Adrinistrative Area

Quad 250k

1008348

User Field

$\cdot 94 / 3$

Site

File Link 10

CIMRI, IMS

ORRIS, GREETA J.

USGS

Report Date $\quad 9401$

-. Location iniormation .-

Quad 24k

UNITED STATES

Courity Code

US

ARIZONA

State Coce

AZ

YAVAPA!

41

Elevation

COCONINC NATIONAL FOREST

HOLBROOK

Lativide

CASNEA SUTTE (1955)

$4895 \mathrm{FT}$

Longitude

$34 \cdot 44 \cdot 30 \mathrm{~N}$

Decimai Lat

34.74160

Acsirasy

$111 \cdot 41 \cdot 341 \%$

Decimai Long

.111 .69277

Section

$A C C$

34

Section Fraction

NE

$\begin{array}{lll}\text { Township } & \text { Range } & \text { Meridian } \\ \text { O16N } & \text { O06E } & \text { GILA AND SALT RIVER }\end{array}$

-- Commocity Inicrmation --

Commodity Type Non-metallic

Ccmmodities VOL

Major VOL

Ore Materials SCORIA, VOLCANIC CINDERS

-. Geology --

Hos: Rock Type VOLCANICS

Host Rock Type Name

VOLCANICS

-. Deposit Description --

-.Individual Ore Bodies-

Deposit Type VOLCANIC

.. Exploration and Development ..

Production Size

Small

Deveiopent Status

Little Deve!cped Producer, Inactive

Page 1 
-. Description of Workings .-

Desc Workings

Surface

Workings Comments QUARRY.

- Reference -

Reference PHILLIPS. K.A., 1987, ARIZONA INDUSTRIAL MINERALS: ARIZONA DEPARTMENT OF MINES AND MINEEAL RESOURCES MINERAL REPORT 4, $185 \mathrm{P}$.

Page 2 


\section{Mineral Resources Data System (MRDS)}

Report Title

issue Date 00100/00

Current Date Monday, Aprii 7, 1997

\begin{tabular}{|c|c|c|}
\hline \multicolumn{2}{|c|}{ Current Time 10:24:50 } & Printed \\
\hline \multicolumn{2}{|c|}{ User Field } & $\cdot 94 / 3$ \\
\hline \multicolumn{2}{|c|}{ File Linik 10} & CIMRI, IMS \\
\hline \multicolumn{2}{|c|}{ Repor Date } & 9401 \\
\hline \multicolumn{2}{|c|}{ Couniry' Code } & US \\
\hline \multicolumn{2}{|c|}{ State Code } & $A Z$ \\
\hline Decimai & Lat & 35.19555 \\
\hline Decimai & Long & -111.80416 \\
\hline Township & Range & Meridian \\
\hline $021 \mathrm{~N}$ & OO6E & GILA AND SALT RIVEA \\
\hline
\end{tabular}

\begin{tabular}{|c|c|}
\hline Record Number & 1008290 \\
\hline Record Type & Site \\
\hline Reporter & ORRIS, GREIA J. \\
\hline Reporiar Affiliation & USGS \\
\hline \multirow[t]{2}{*}{ Site Name } & BELLEMCNT NO. 3 CIND \\
\hline & -. Location inisrmation .- \\
\hline Country & UNITED STATES \\
\hline State & ARIZONA \\
\hline County & COCONINO \\
\hline Land Status & 50 \\
\hline Administrative Area & NAVAJO AFMY DEPOT \\
\hline Quad 250k & FLAGSIAFE \\
\hline Ouad 24k & BELLEMCINT (1980) \\
\hline Latituce & $35 \cdot 11 \cdot 4 \div N$ \\
\hline Longitude & $111 \cdot 48 \cdot 15: 4$ \\
\hline Accuracy & $A C C$ \\
\hline Section & Section Fraction \\
\hline 18 & \\
\hline
\end{tabular}

$\begin{array}{ll} & \text { - Commacity Information .. } \\ \text { Commodity Type } & \text { Non-meiailic } \\ \text { Commodities } & \text { VOL } \\ \text { Major } & \text { VOL } \\ \text { Ore ilaterials } & \text { VOLCANIC CINDERS }\end{array}$

Host Rock Type VOLCANICS

Host Rock Type Name Age

VOLCANICS

Age Host Rock Unit Name Age 
.- Description of Workings .-

Desc Workings Surface

Workings Comments QUARRY.

\section{- Relerence -}

Reference PHILLIPS, K.ศ., 1987, ARIZONA INDUSTRIAL MINEFALS: ARIZONA DEPARTMENT OF MINES AND MINUERAL RESOURCES MINERAL REPORT 4,185 P.

Page 2 


\section{Mineral Resources Data System (MRDS)}

Report Title

Issue Date 00/00/00

Current Date Monday, April T. 1997

Current Time 10:24:50

Number 85 of 103

Printed 85 of 103

\begin{tabular}{|c|c|}
\hline Record Number & 1008291 \\
\hline Record Type & Site \\
\hline Reporter & ORRIS. GRETA J. \\
\hline Reporter Affiliation & USGS \\
\hline \multirow[t]{2}{*}{ Site Name } & BELLEMONT NO. 4 CINDE: \\
\hline & -- Location Iniormation - \\
\hline Couniry & UNITED STATES \\
\hline State & ARIZONA \\
\hline County & COCONINO \\
\hline Ouad 250k & FLAGSTAFF \\
\hline Quad $24 k$ & BELLEMCNT (1980) \\
\hline Latitude & $35.11 .55 \mathrm{~N}$ \\
\hline Longitude & $111.48 .06 \mathrm{~W}$ \\
\hline Acsuracy & $A C C$ \\
\hline \multirow{3}{*}{$\begin{array}{l}\text { Section } \\
18\end{array}$} & Section Fraction \\
\hline & \\
\hline & -- Commodity Information -- \\
\hline Commodity Type & Non-metallic \\
\hline Commodities & VOL \\
\hline Major & VOL \\
\hline \multirow[t]{2}{*}{ Ore Materials } & VOLCANIC CINDERS \\
\hline & .. Geology .. \\
\hline Hosi Rock Type & VOLCANICS \\
\hline
\end{tabular}

Host Rock Type Name

Age

User Field

$\cdot 94 / 3$

File Link 10

CIMAI, IMS

Report Date

9401

Country Code

US

State Code

$A Z$

Desimal Lat

35.19861

Desimal Long

.111 .80166

VOLCANICS

$\begin{array}{lll}\text { Township } & \text { Range } & \text { Meridian } \\ \text { O21N } & \text { OO6E } & \text { GllA AND SALT RIVER }\end{array}$

$\begin{array}{ll} & \text {-. Deposit Cescription -- } \\ \text { Deposit Type } & \text {-Individual Ore Bodies-- } \\ \text { VOLCANIC }\end{array}$

.. Exploration and Development ..

Production Size Small

Developent Status Little Developed Producer, Inactive

Host Rock Unit Name

Age

VOLCANIC

Desc Workings Surface

-. Descripticn of Workings ..

Page 1 
Workings Comments QUARRY.

-. Reference -

Reference PHILLIPS, K.A., 1987, ARIZONA INDUSTRIAL MINERALS: ARIZONA DEPARTMENT OF MINES AND MINERAL RESOURCES MINERAL REPORT 4, 185 P.

Page 2 


\section{Mineral Resources Data System (MRDS)}

Report Title

Issue Date 00/00/00

Current Date Monday, April $i, 1997$

Current Time 10:24:50

Number 86 of 103

Record Number 1008292

Record Type Site

Reporter

ORRIS. GRETA J.

Reporter Affiliation USGS

Site Name

BELLEMONT NO. 5 CINDER PIT

User Field

Printed 86 of 103

Sile Name

- Lccation information -

Country

UNITED STATES

State

ARIZONA

County

COCONINO

Quad 250k

FLAGSTAFF

Quad 24k

BELLEMONT (1980)

Latitude

$35-14.41 \mathrm{~N}$

File Link ID

'94/3

Longitude

$111.52 .10 \mathrm{~W}$

Decimai Lat

35.24472

Acsuracy

$\mathrm{ACC}$

Section

Section Fraction

33

-. Commcoity Iniormation -.

Commodity Type

Non-metallic

Commodities

VOL

Major

VOL

Ore Materials

VOLCANIC CINDERS

- Geclogy -

Host Rock Type VOLCANICS

Host Rock Type Name

VOLCANICS

Country Code

US

State Code

$A Z$

Decimai Long

$.111 .36 \geqslant 44$

$\begin{array}{lll}\text { Township } & \text { Range } & \text { Merician } \\ \text { 022N } & \text { O05E } & \text { GILA iND SALT RIVER }\end{array}$

-- Deposit Description -.

--Individual Ore Bodies-

Deposit Type

VOLCANIC

-. Exploration and Development -.

Production Size Small

Developent Status Little Developed Producer, Inactive

- Description of Workings .-

Desc Workings

Surface

Host Rock Unit Name

Age 
Workings Comments QUARRY.

\section{-- Reference -}

Reierence PHILLIPS. K.A., 1987, ARIZONA INCLSTRIAL MINERALS: ARIZONA DEPARTMENT OF MINES AND MINERAL RESOURCES MINERAL REPORT $\div$. 185 P.

Pzฐュ 2 


\section{Mineral Resources Data System (MRDS)}

Report Title

Issue Date 00100/00

Current Date Monday, April 7, 1997

Current Time 10:24:50

Number 87 of 103

Printed 87 of 103

\begin{tabular}{ll}
\hline Reccrd Number & 1008293 \\
Record Type & Site \\
Repcrter & ORRIS, GRETA J. \\
Reporter Affiliation & USGS \\
Site Name & BELLE.NONT NO. 6 CINDER PIT
\end{tabular}

$\begin{array}{ll}\text { User Field } & \text { '94/3 } \\ \text { File Lirk ID } & \text { CIMRI, IMS } \\ \text { Repor Date } & 9401\end{array}$

- Locaticn Iniormation -

$\begin{array}{ll}\text { Country } & \text { UNITED STATE } \\ \text { State } & \text { ARIZONA }\end{array}$

Counity Code US

State Code AZ

County COCONINO

Quad 250k FLAGSTÁFF

Quad 24k BELLEMCNT (1980)

Latituje

$35 \cdot 14 \cdot 46 \mathrm{~N}$

Longitude

$111.52 .07 \mathrm{~W}$

Decimai Lat

35.24611

Accurazy

$A C C$

Section

Section Fraction

33

Town

Range

Meridian

OO5E

GILA AND SALT RIVER

-. Commicuity Information ..

Commodity Type Non-metailic

Commodities VOL

Major VOL

Ore Materials VOLCANIC CINDERS

-- Geology --

Host Rock Type VOLCÂH:CS

Host Rock Type Name

Age

Host Rock Unit Name

Age

VOLCANIICS

-- Deposit Description --

--Individual Ore Bodies-

Depcsit Type VOLCANIC

-. Exploration and Development --

Production Size Small

Developent Status Little Developed Producer, Inactive

-- Description of Workings .-

Desc Workings

Surface

Page 1 
Workings Comments QUARRY.

\author{
- Reference - \\ Reference PHILLIPS. K.A., 1987, ARIZONA INDUSTRIAL MINERALS: ARIZONA DEPARTMENT OF MINES AND MINEPAL \\ RESOURCES MINERAL REPORT 4, 185 P.
}

Page 2 


\section{Mineral Resources Data System (MRDS)}

Report Title

Issue Date 00/00/00

Number 88 of 103

Current Date Monday, April 7, 1997

Current Time 10:24:50

Printed 88 of 103

\begin{tabular}{|c|c|c|c|c|}
\hline Record Number & 1008294 & \multicolumn{2}{|c|}{ User Field } & $\cdot 94 / 3$ \\
\hline Record Type & Site & \multicolumn{2}{|c|}{ File Link 10} & CIMAI, MSS \\
\hline Reporter & ORRIS, GREIA J. & & & \\
\hline Reporter Affiliation & USGS & \multicolumn{2}{|c|}{ Report Date } & 9401 \\
\hline \multirow[t]{2}{*}{ Site Name } & BELLEMONT NO. 7 CINDER PIT & & & \\
\hline & -- Lccation Iniermation - & \multirow{2}{*}{\multicolumn{2}{|c|}{ Country Code }} & \\
\hline Country & UNITED STATES & & & US \\
\hline State & ARIZONA & \multirow{2}{*}{\multicolumn{2}{|c|}{ State Code }} & $A Z$ \\
\hline County & COCONINO & & & \\
\hline Quad 250k & FLAGSTAFF & & & \\
\hline Quad 24k & BE:LEMCNT (1980) & & & \\
\hline Latitude & $35 \cdot 15 \cdot 02 \mathrm{~N}$ & Decima & Lat & 35.25055 \\
\hline Longitude & $111 \cdot 52 \cdot 13 W$ & Decima & Long & $.111 .87 \subset 27$ \\
\hline Accuracy & $A C C$ & & & \\
\hline Section & Section Fraction & Township & Range & \multirow{2}{*}{$\begin{array}{l}\text { Merician } \\
\text { GILÁ AND SALT RIVER }\end{array}$} \\
\hline \multirow[t]{2}{*}{33} & & $022 \mathrm{~N}$ & OOSE & \\
\hline & .- Commcdity Information .- & & & \\
\hline Commodity Type & Non-metallic & & & \\
\hline Commodities & VOL & & & \\
\hline Major & VOL & & & \\
\hline \multirow[t]{2}{*}{ Ore Materials } & VOLCANIC CINDERS & & & \\
\hline & .- Geclogy -- & & & \\
\hline Host Rock Type & VOLCANICS & & & \\
\hline \multirow{4}{*}{$\begin{array}{l}\text { Host Rock Type } \\
\text { VOLCANICS }\end{array}$} & Vame & Host Rock L & Init Name & Age \\
\hline & & & & \\
\hline & -- Deposit Description -- & & & \\
\hline & --Individual Ore Bodies- & & & \\
\hline \multirow[t]{2}{*}{ Deposit Type } & VOLCANIC & & & \\
\hline & .- Exploration and Development -- & & & \\
\hline Production Size & Small & & & \\
\hline \multirow[t]{2}{*}{ Developent Status } & Little Developed Producer, Inactive & & & \\
\hline & - Description of Workings - & & & \\
\hline Desc Workings & Surface & & & \\
\hline
\end{tabular}

Page 1 
Workings Comments QUARRY.

- Reference -

Reference PHILLIPS, K.A., 1987, ARIZONA INDUSTRIAL MINERALS: -ARIZONA DEPARTMENT OF MINES AND MINERAL RESOURCES MINERAL REPORT 4, $185 \mathrm{P}$.

Page 2 


\section{Mineral Resources Data System (MRDS)}

Report Title

Issue Date 00/00100

Current Date Monday, April 7,1997

Current Time 10:24:50

Number 89 of 103

Record Number 1008295

Record Type Site

User Field

Printed 89 of 103

Reporter

ORRIS. GREETA J.

Reporter Affiliation USGS

Site Name

GARLAND PRAIRIE NO. 1 CINDER PIT

File Link 10

$\cdot 94 / 3$

Repor Date

CIMRI, IMS

-- Locaticn Iniormation -

\section{Country}

UNITED STATES

State

ARIZONA

County

COCONINO

Couniry Code

US

State Code

$A Z$

Land Status

41

Administrative Area KAIBAB NATICNAL FOREST

Quad 250k FLAGSTAFF

Quad $24 k$

GARLAND FARIRIE (1974)

Elevation

$7040 \mathrm{FT}$

Latitude

$35-14-42 \mathrm{~N}$

Decimal Lat

35.245

Longitude

$111 \cdot 55 \cdot 58 \mathrm{~W}$

Decimal Long

$-111.93277$

Accuragy

$A C C$

Section Section Fraction

35

$022 \mathrm{~N}$

Range

Meridian

OO4E

GILA AND SALT RIVER

-. Commecity Iniormation --

Commodity Type

Non-metallic

Comrodities VOL

Major VOL

Ore Materials VCLCANIC CINDERS

-. Geology -

Hos: Rcck Type VOLCANICS

Host Rock Type Name

Age

Host Rock Unit Name

Age

-. Deposit Description --

--Individual Ore Bodies-

Deposit Type VOLCANIC

.. Exploration and Development ..

Production Size

Small

Developent Status Little Develcped Producer, Inactive

Page 1 
- Description of Workings .-

Dese Workings

Surlace

Workings Comments QUARRY.

- Reierence -

Reference

PHILLIPS. K.A.. 1987, ARIZONA INCUSTRIAL MINERALS: ARIZONA DEPARTMENT OF MINES AND MINERAL RESOURCES MINERAL REPORT 4, 185 P.

Page 2

$8-173$ 


\section{Mineral Resources Data System (MRDS)}

\section{Report Title}

Issue Date 00100/00

Current Date Monday, April 7, 1997

Current Time :0:24:50

Number 90 of 103

Record Number

1008296

User Fieid

Printed 90 of 103

Record Type

Site

File Lirix 10

$94 / 3$

Reporter

ORRIS, GRETA J.

Repcrter Affiliation

USGS

Site Name

GARLAND PRAIRIE NO. 2 CINDER ?IT

Repor: Date

CIMRI, IMS

- Lecation information -

Country

UNITED STATES

Countr' Code

US

State

ARIZONA

State Code

AZ

County

COCONINO

Land Status $\quad 50$

Administrative Area NAVAJO ARMY DEPOT

Quad 250k

FLAGSTAFF

Quad 24k

GARLAND PRAIRIE (1974)

Elevation

$7470 \mathrm{FT}$

Latitude

$35-11-25 \mathrm{~N}$

Longitude

$111.53 .29 \mathrm{~W}$

Accuracy

$A C C$

Section

Section Fraction

20

Township Range

Meridian

$021 \mathrm{~N}$

OOSE

35.19027

Decirt: long

.111 .89138

.. Commodity Information .-

Commodity Type Non-metallic

Commodities VOL

Major VOL

Ore inateriais VOLCANIC CINDERS

- Geology -

Hos: Rock Type

VOLCANICS

Host Rock Type Name

Host Rock Unit Name

Age

-- Deposit Description ..-Individual Ore Bodies-

Depcsit Type VOLCANIC

Production Size

-- Exploration and Development -.

Developent Status
Small

Little Developed Producer, Inactive 
-- Description of Workings -

Desc Workings Surface

Workings Comments QUARRY.

-. Reference -

Reference PHILLIPS, K.A., 1987, ARIZONA INCUSTRIAL MINERALS: ARIZONA DEPARTMENT OF MINES AND MINEFAL RESOURCES MINERAL REPORT 4. 185 P.

Page 2

$B-175$ 


\section{Mineral Resources Data System (MRDS)}

Report Title

Issue Date 00100100

Current Date Monday, April 7. 1997

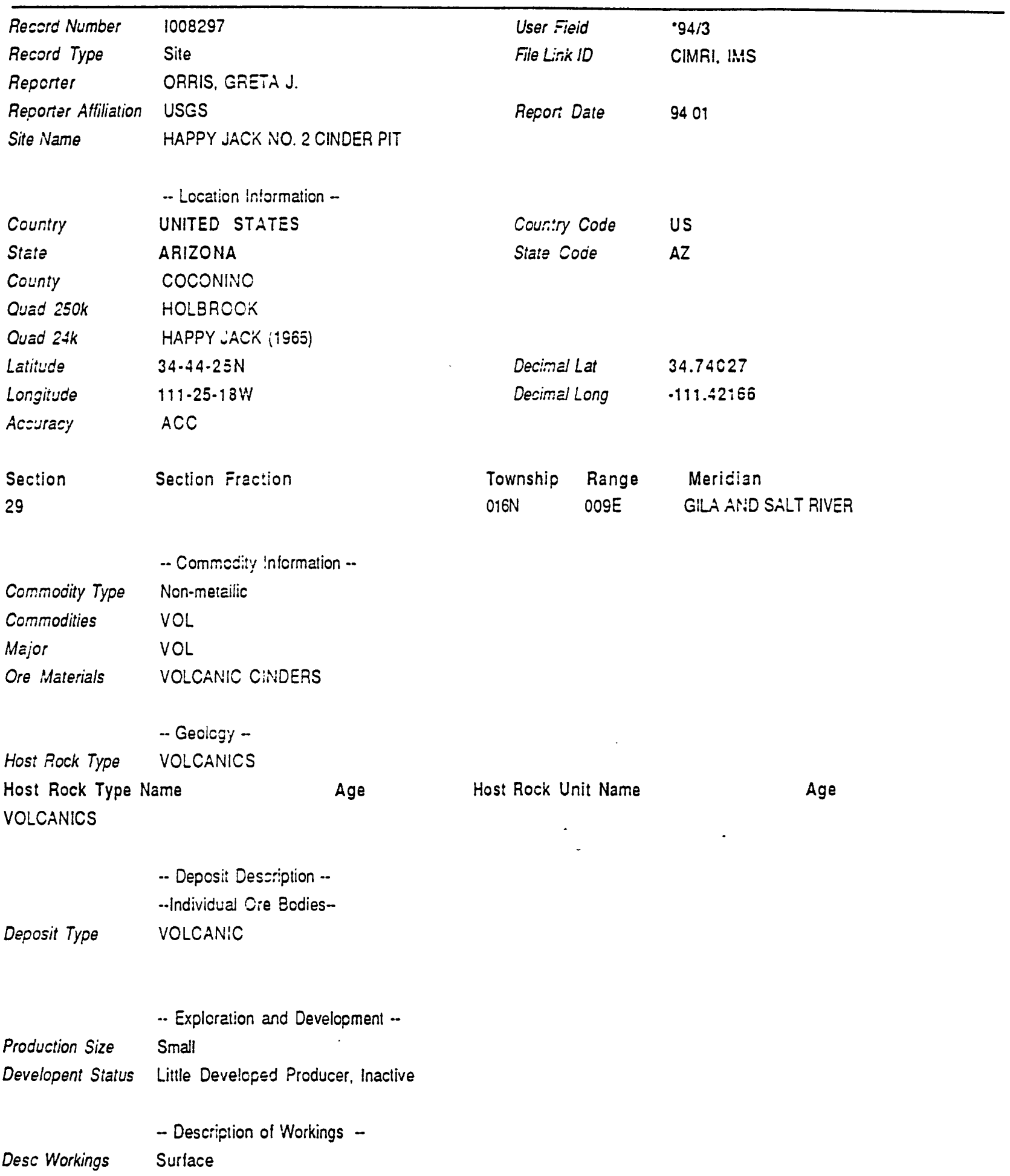


Workings Comments QUARRY.

$\begin{array}{ll}\text { - Reference - } \\ \text { Reference } & \text { PHILLIPS, K.A., 1987, ARIZONA INDUSTRIAL MINERALS: ARIZONA DEPARTMENT OF MINES AND MINERAL } \\ & \text { RESOURCES MINERAL REPORT 4, } 185 \text { P. }\end{array}$

Page 2

$B-177$ 


\section{Mineral Resources Data System (MRDS)}

Report Title

Issue Date 00100100

Current Date Monday, April 7,1997

Current Time 10:24:50

Number 92 of 103

Record Number

1008298

Record Type

Site

User Field

Printed 92 of 103

Reporter

ORRIS, GRETA J.

Reporter Affiliation USGS

Site Name

HAPPY UACK NO. 3 CINDER PIT

File Link 10

$\cdot 94 / 3$

Repori Date

CIMRI, IMS

- Location Inicrmation --

Country

UNITED STATES

State

ARIZONA

Couning Code

US

County

COCONINO

State Code

$A Z$

Quad 250k

HOLBROOK

Quad 24k

HAPPY JACK (1965)

Latitude

$34.44 .29 N$

Dec:m: a Lat

34.74138

Longitude

$111 \cdot 25-00 \mathrm{i}$

Decirisi Long

.111 .41666

Acsuracy

$A C C$

Section

Section Fraction

29

Township Range

Meridian

O1ÔN OOgE

GILA AND SALT RIVER

- Commecity Information .-

Commodity Type

Non-metallic

Commodities VOL

Major VOL

Ore Materials VOLCANIC CINDERS

-. Geolocy -

Host Rock Type VOLCANICS

Host Rock Type Name

VCLCANICS

-- Deposit Description --

--Individual Ore Bodies.-

Deposit Type VOLCANIC

-. Exploration and Deveiopment --

Production Size Small

Developent Status Little Developed Producer, Inactive

Desc Workings Surface

-. Description of Workings -

Page 1 
Workings Comments QUARRY.

\section{- Reference -}

Reference PHILLIPS, K.A., 1987, ARIZONA INDUSTRIAL MINERALS: ARIZONA DEPARTMENT OF MINES AND MINEFAL RESOURCES MINERAL REPORT 4, 185 P.

Page 2 


\section{Mineral Resources Data System (MRDS)}

Report Title

Issue Date 00100/00

Current Date Monday, April 7. 1997

Current Time 10:24:50

Number 93 of 103

Printed 93 of 103

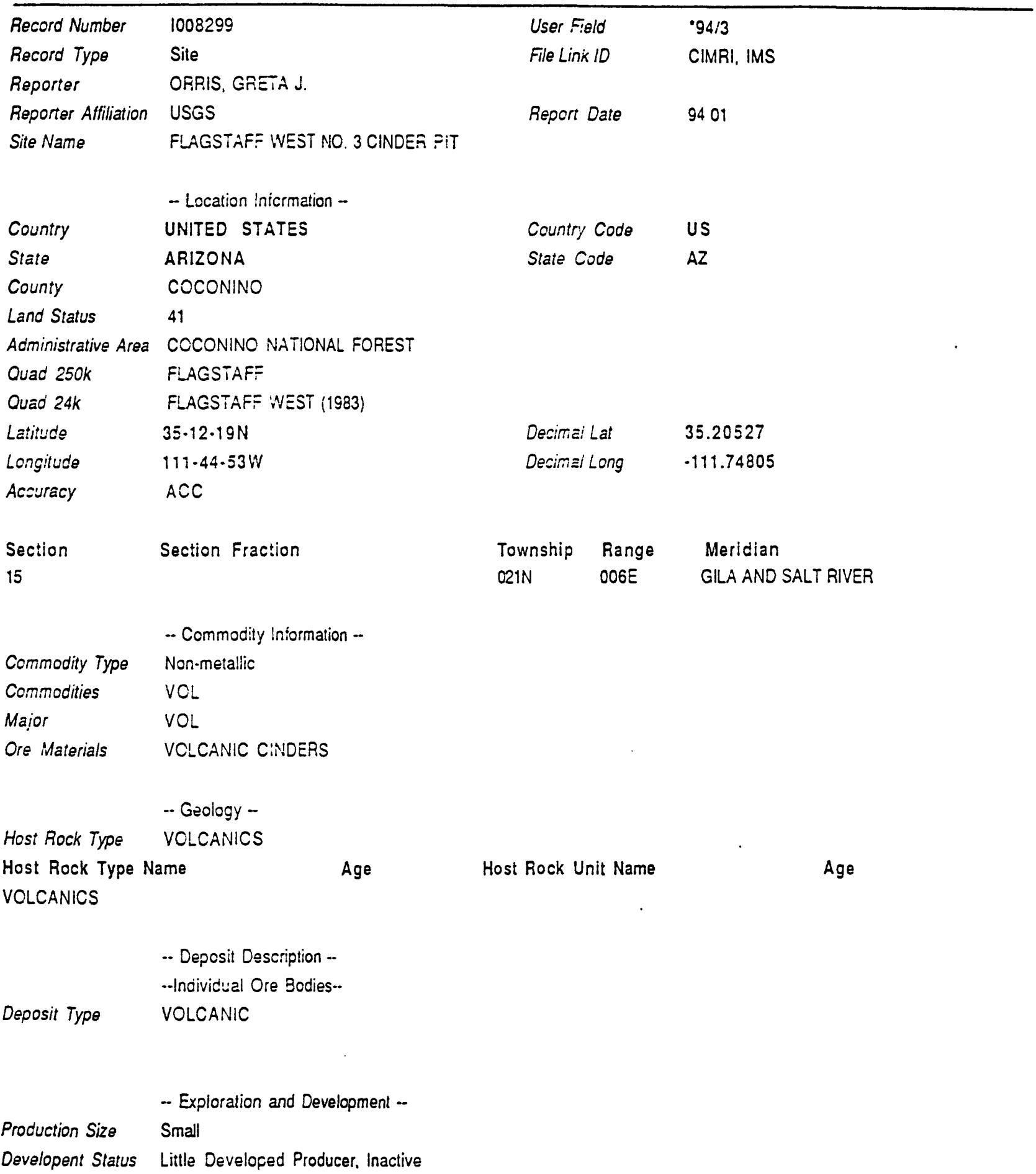


-- Description of Workings .-

Desc Workings Surface

Workings Comments QUARRY.

- Relerence -

Reference PHILLIPS, K.A., 1987, ARIZONA INDUSTRIAL MINERALS: ARIZONA DEPARTMENT OF MINES AND MINESAL RESOURCES MINERAL REPORT 4, 185 ?.

Page 2 


\section{Mineral Resources Data System (MRDS)}

Report Title

Issue Date 00/00/00

Current Date Monday, April $T$, ISפT

$\begin{array}{ll}\text { Current Time 10:24:50 } & \text { Number } 94 \text { of } 103 \\ \text { Printed } 94 \text { of } 103\end{array}$

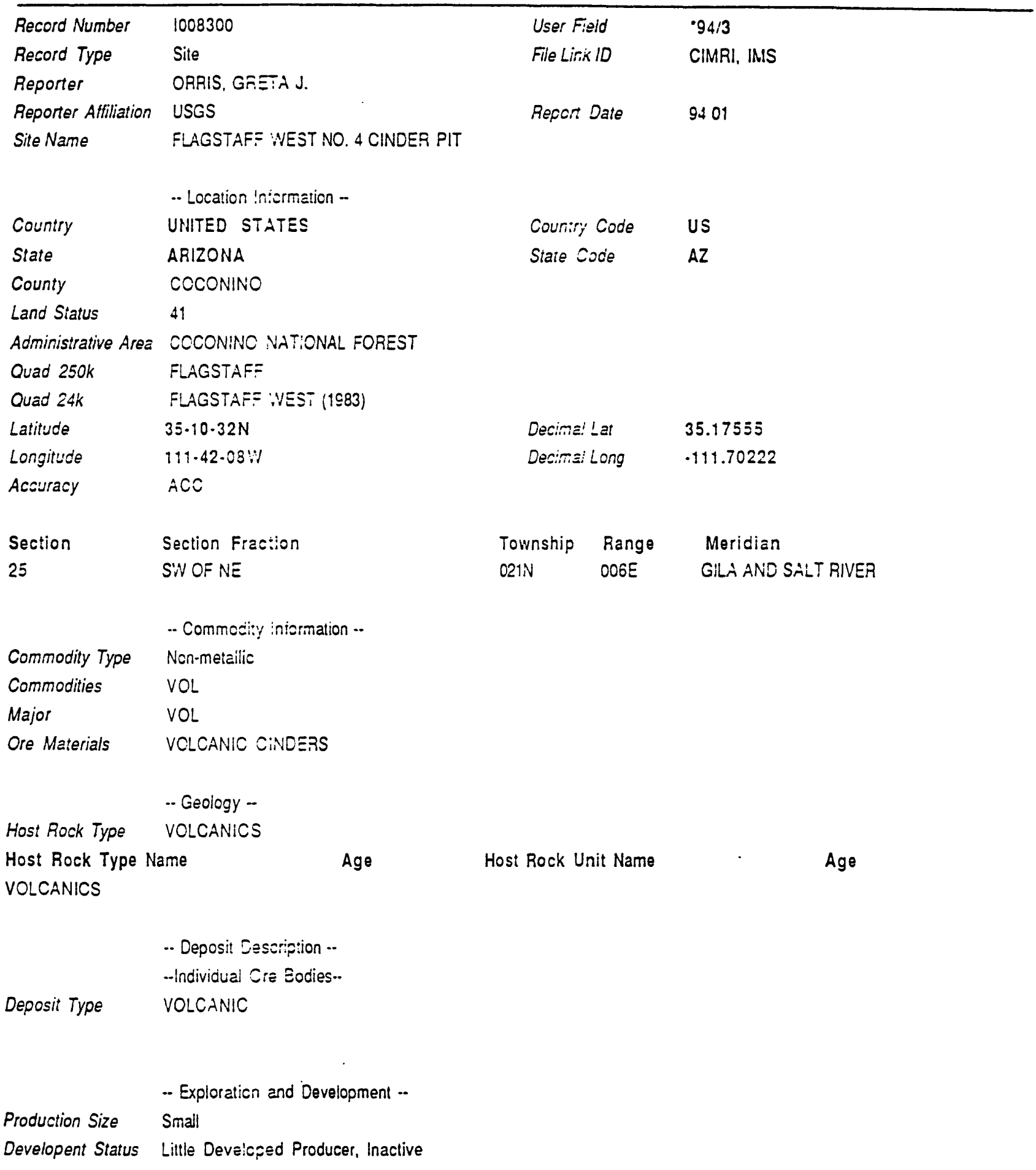


- Description of Workings ..

Desc Workings Surlace

Workings Comments QUARRY.

Reference

- Reference -

PHILLIPS, K.A., 1987, ARIZONA INDUSTRIAL MINEFALS: ARIZONA DEPARTMENT OF MINES AND MINE:AL RESOURCES MINERAL REPORT $\div 185 P$.

Page 2 


\section{Mineral Resources Data System (MRDS)}

Report Title

Issue Date 00100100

Current Date Monday, April 7, 1997

Current Time 10:24:50

Numioer 95 of 103

Record Number 1008301

Record Type Site

Reporter

ORRIS, GRETA J.

Reporter Affiliation USGS

Site Name

FLAGSTAFF WEST NO. 5 CINDER PIT

User Field

File Linik 10

Report Date

- Lccation Information -

Country

UNITED STATES

State

ARIZONA

County

COCONINO

Land Status

41

Administrative Area

Quad 250k

COCONINO NATIONAL FOREST

Quad 24k

FLAGSTAFF

Latitude

FLAGSTAFF 'VEST (1983)

Longitude

Accuracy

$35 \cdot 10.27 \mathrm{~N}$

$111 \cdot 42 \cdot 22 \mathrm{~W}$

ACC

Section

Section Fraction

25

SE OFNE

.. Commodity Information .-

Commodity Type Non-metallic

Commodities VOL

Major VOL

Ore Materials VOLCANIC CINDERS

-. Geology ..

Host Rock Type VOICANICS

Host Rock Type Name

US

State Code

AZ

- $94 / 3$

CIMRI, INS

Decimal Lat

35.17416

Deciniล Long

.111 .70611

VOLCANICS

-. Deposit Description .-

--Incividual Ore Bodies-

Deposit Type VOLCANIC

-- Exploration and Development -

Production Size

Small

Developent Status Little Develcped Producer, Inactive
Printed 95 of 103 
-. Description of Workings --

Dese Workings Surface

Workings Comments QUARRY.

- Relerence -

Reference PHILLIPS, K.A.. 1987, ARIZONA INDUSTRIAL MINERALS: ARIZONA DEPARTMENT OF MINES AND MINEPAL RESOURCES MINERAL REPORT 4, 185 P.

Page 2 


\section{Mineral Resources Data System (MRDS)}

Report Titie

Issue Date 00/00/00

Current Date Monday, April $i, 1997$

Numiber 96 of 103

Printed 96 of 103

\begin{tabular}{|c|c|c|c|c|}
\hline Record Number & 1008302 & \multicolumn{2}{|c|}{ User Fieid } & $\cdot 94 / 3$ \\
\hline Record Type & Site & \multicolumn{2}{|c|}{ File Linik 10} & CIMRI, IMS \\
\hline Reporter & ORRIS, GFETA J. & & & \\
\hline Reporter Affiliation & USES & \multicolumn{2}{|c|}{ Repor: Date } & 9401 \\
\hline \multirow[t]{2}{*}{ Site Name } & BASALT & & & \\
\hline & .- Location Inicrmation .- & & & \\
\hline Country & UNITED STATES & \multicolumn{2}{|c|}{ Couri:r, Code } & US \\
\hline State & ARIZONA & \multicolumn{2}{|c|}{ State Zode } & $A Z$ \\
\hline County & GiLA & & & \\
\hline Land Status & 41 & & & \\
\hline Administrative Area & TONTO NATIONAL FOREST & & & \\
\hline Quad 250k & HCLSPOOK & & & \\
\hline Quad $62.5 k$ & PINE & & & \\
\hline Quad 24k & BUC'KHEAD MESA & & & \\
\hline Latitude & $34-13-45 N$ & Destr: & Lat & 34.3125 \\
\hline Longitude & $111 \cdot 24 \cdot 15 W$ & Desima & iong & .111 .40416 \\
\hline Acsuracy & EST +i-0.5 MLLE. & & & \\
\hline Section & Section Fraction & $\begin{array}{l}\text { Township } \\
011 \mathrm{~N}\end{array}$ & $\begin{array}{l}\text { Range } \\
\text { OOgE }\end{array}$ & $\begin{array}{l}\text { Meridian } \\
\text { GLAAND SALT RIVER }\end{array}$ \\
\hline \multirow[t]{2}{*}{ Losation Comments } & NE: 4 OF THE TOWNSHIP. & & & \\
\hline & -- Commodity Information .- & & & \\
\hline Commodity Type & Non-metallic & & & \\
\hline Commodities & VOL & & & \\
\hline Major & $\mathrm{VCl}$ & & & \\
\hline \multirow[t]{2}{*}{ Ore Materials } & BASALT & & & \\
\hline & - Geology - & & & \\
\hline Host Rock Type & BASALT & & & \\
\hline \multirow{3}{*}{$\begin{array}{l}\text { Host Rock Type } \\
\text { BASALT }\end{array}$} & Age & \multirow{2}{*}{\multicolumn{2}{|c|}{ Host Rock Unit Name }} & Age \\
\hline & & & & \\
\hline & $\begin{array}{l}\text {-- Deposit Description .- } \\
\text {.-Individual Ore Bodies-- }\end{array}$ & & & \\
\hline Deposit Type & VOLCANIC & & & \\
\hline Production Size & $\begin{array}{l}\text {.- Exploration and Development - } \\
\text { No }\end{array}$ & & & \\
\hline
\end{tabular}


Developent Status Occurrence

- Description of Workings --

- Relerence -

Reference

PHILLIPS. K.A., 1987, ARIZONA INDUSTRIAL MINERALS: ARIZONA DEPARTMENT OF MINES AND MINEPAL RESOURCES MINERAL REPORT 4. 185 P.

Page 2 


\section{Mineral Resources Data System (MRDS)}

\section{Report Title}

Issue Date 00/00/00

Current Date Monday, April T, 1997

Current Time 10:24:50

Number 97 of 103

Printed 97 of 103

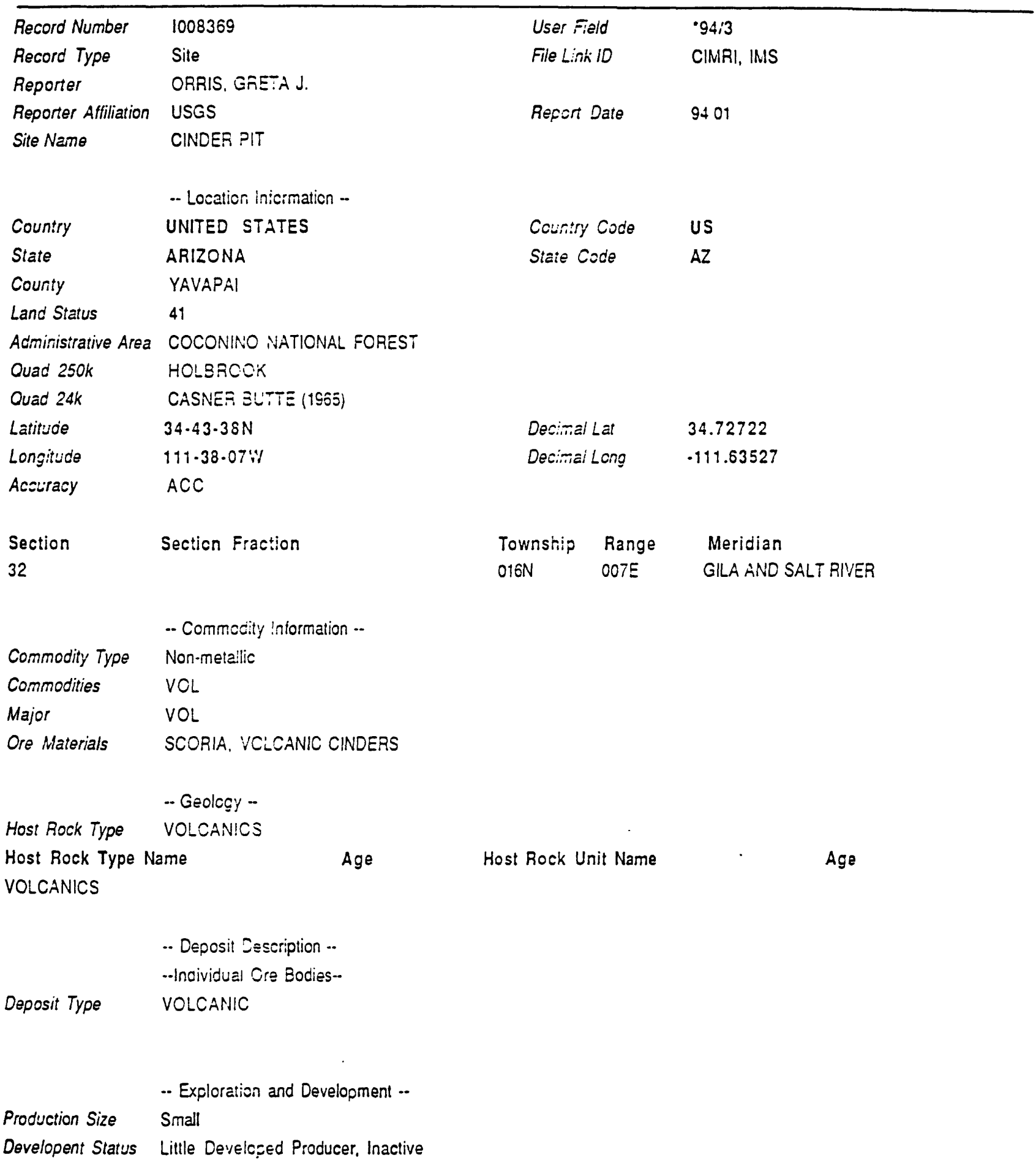


- Description of Workings .-

Desc Workings Surface

Workings Comments QUARRY.

- Relerence -

Reierence PHILLIPS, K.A., 1987, ARIZONA INDUSTRIAL MINEPALS: ARIZONA DEPARTMENT OF MINES AND MINEFAL RESOURCES MINERAL REPORT 4, 185 P.

Page 2 


\section{Mineral Resources Data System (MRDS)}

Report Title

Issue Date 00/00/00

Current Date Monday. April 7, 1997

Current Time 10:24:50

Number 98 of 103

Printed 98 of 103

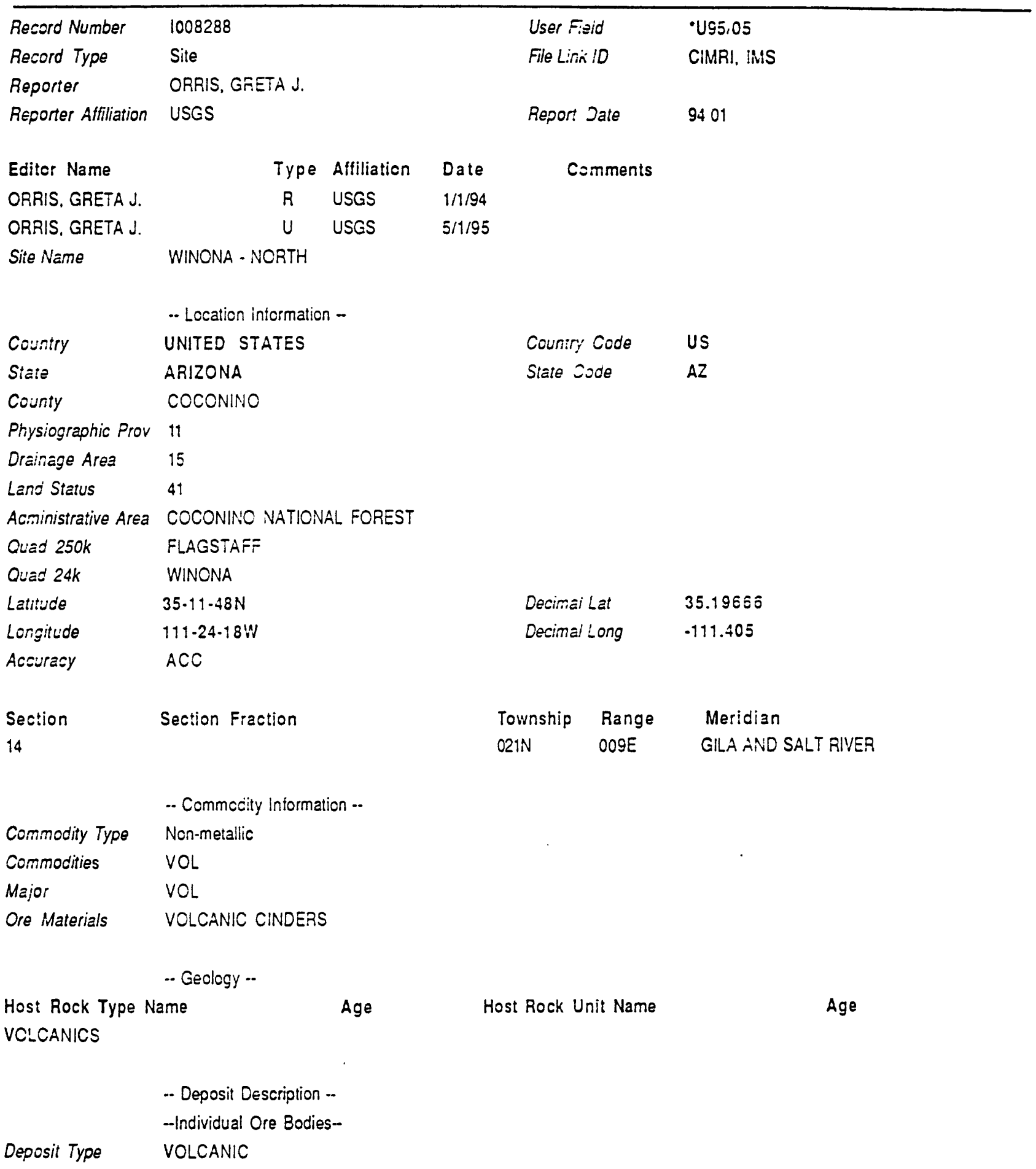


-- Exploration and Development .-

Production Size Small

Developent Status Developed Producer, Inactive

- Description of Workings ..

Desc Workings

Surface

Workings Comments QUARRY.

- Reference -

Reference

PHILLIPS, K.A., 1987, ARIZONA INDUSTRIAL MINERALS: ARIZONA DEPARTME.VT OF MINES AND MINEFAL RESOURCES :IINERAL REPORT 4, 185 P.

Info Source $\quad 94107 / 20$

Page 2 


\section{Mineral Resources Data System (MRDS)}

Report Titlo

Issue Date 00/00/00

Current Date Monday, April 7, 1997

Current Time 10:24:50

Numier 99 of 103

Printed 99 of 103

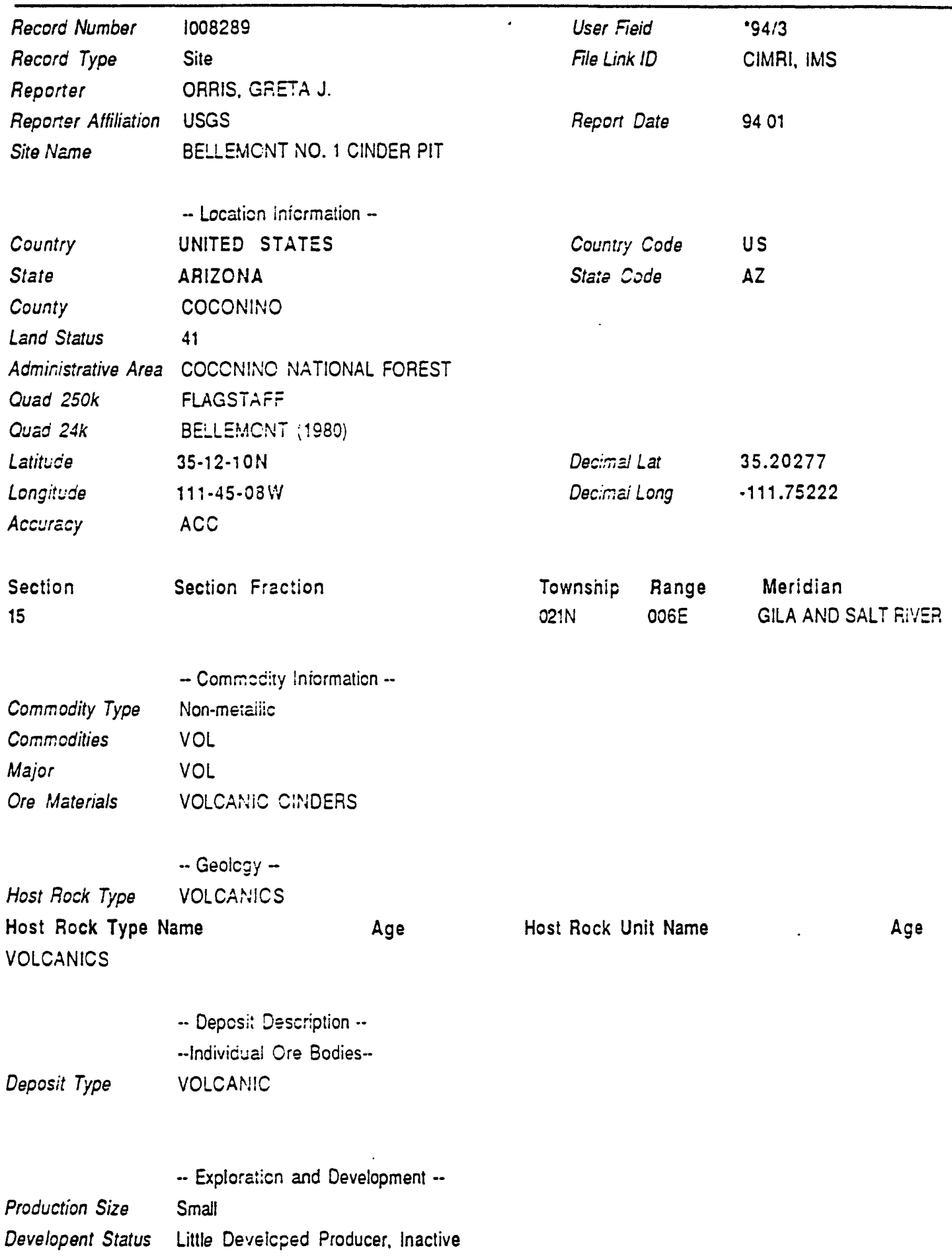

Page 1 
- Description of Workings -

Desc Workings Surface

Workings Comments QUARRY.

- Relerence -

Reference PHILLIPS, K.A., 1987, ARIZONA INDUSTRIAL MINERALS: ARIZONA DEPARTMENT OF MINES AND MINE.SAL RESOURCES MINERAL REPORT 4, 185 P.

Page 2 


\section{Mineral Resources Data System (MRDS)}

\section{Report Title}

Issue Date 00100100

Current Date Monday, April 7, 1997

Current Time 10:24:50

Number 100 of 103

Record Number

1008458

User Field

File Link ID

- 9415

Record Type Site

Reporter

ORRIS, GRETA J.

Reporter Affiliation USGS

Site Name

PHOENIX CEMENT CO. CLAIMS

Repcr Date $\quad 9402$

- Location Iniormation -

Country

UNITED STATES

Couritry Code

US

State

ARIZONA

County

YAVAPAI

Land Status

41

Administrative Area

Quad 250k

PRESCOT NATIONAL FOREST

Ouad 24k

PRESCOTT

Latitude

CLARKDALE

Longitude

$34 \cdot 47 \cdot 45 \mathrm{~N}$

State Coce

$A Z$

Accuracy

$112 \cdot 07-25 W$

Decimal Lat

34.79583

Decmai Long

$-112.12361$

Section Section Fraction

03

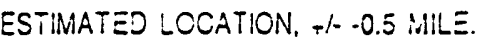

$\begin{array}{lll}\text { Township } & \text { Range } & \text { Meridian } \\ 016 \mathrm{~N} & \text { OO2E } & \text { GILA AND SALT RIVER }\end{array}$

-. Commodity Information -.

Commodity Type Non-metallic

Commodities LST

Major LST

Ore Materials LIMESTONE

-- Geology -

Hosi Rock Type LIMESTCNE

Host Rock Type Name

Age

Host Rock Unit Name

Age

-. Deposit Description --

--Individual Ore Bodies-

Deposit Type SEDIMENTARY

.. Exploration and Development ..

Production Size

No

Developent Status

Prospect, Inactive

Page 1 
Record Number 1008458

(....Continued)

.. Description of Workings ..

- Reference -

Reference

PHILLIPS, K.A., 1987, ARIZONA INDUSTRIAL MINERALS: ARIZONA DEPARTMENT OF MINES AND MINERAL RESOURCES MINERAL REPORT 4, 185 P.

Page 2

$B-195$ 


\section{Mineral Resources Data System (MRDS)}

Report Title

Issue Date 00/00/00

Current Date Monday, April 7, 1997

Current Time 10:24:50

Number 101 of 103

Printed 101 of 103

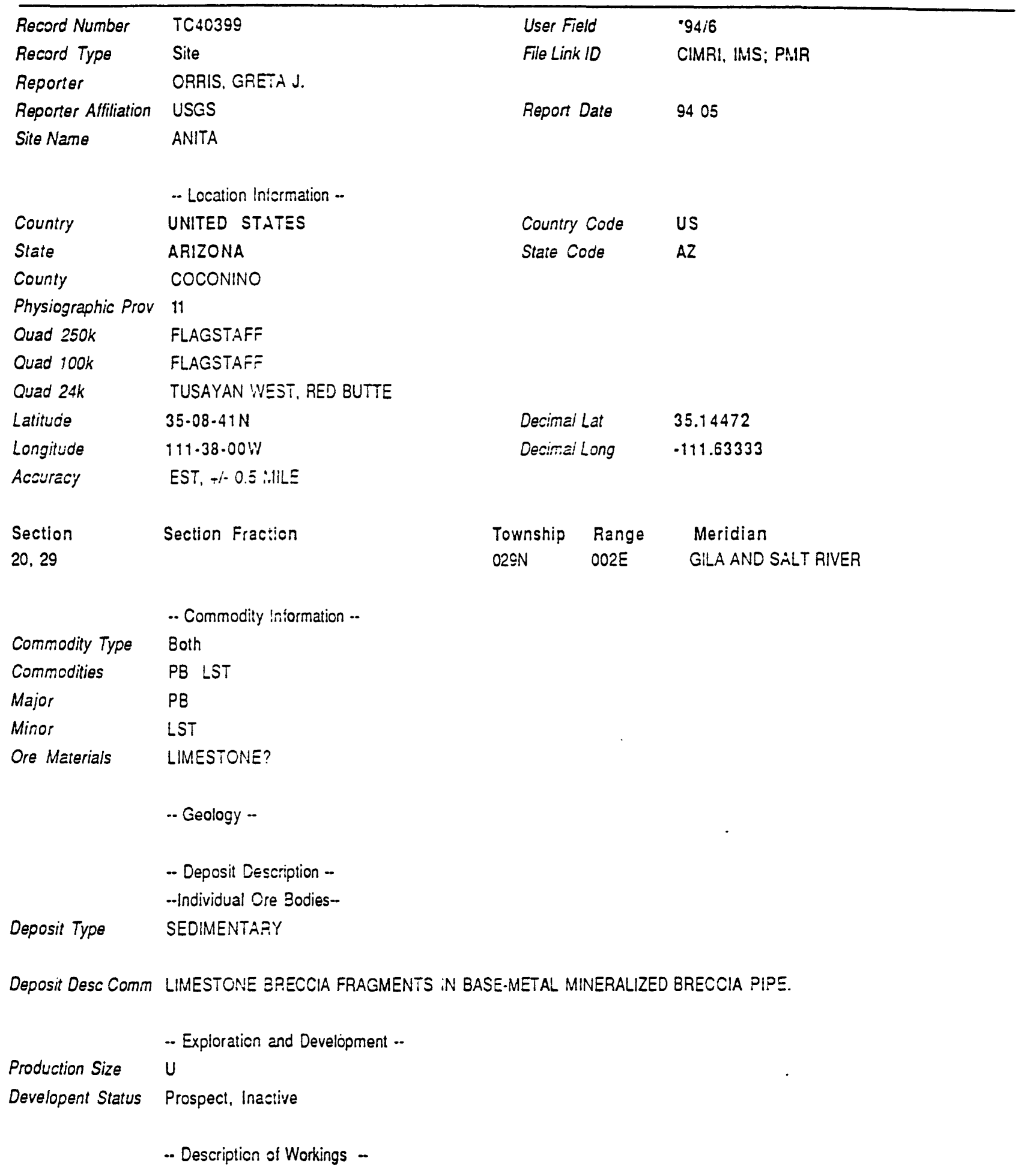

Page 1 
- Reference --

Reference PHILLIPS, K.A., 1987, ARIZONA INCUSTRIAL MINERALS: ARIZONA DEPARTMENT OF MINES AND MINEFAL RESOURCES REPORT 4, 185 P.

Prod Comments INACTIVE PROSPECT

Page 2 


\section{Mineral Resources Data System (MRDS)}

Report Title

Issue Date 00100/00

Numiear 102 of 103

Current Date Monday, April 7, 1997

Current Time 10:24:50

Printed 102 of 103

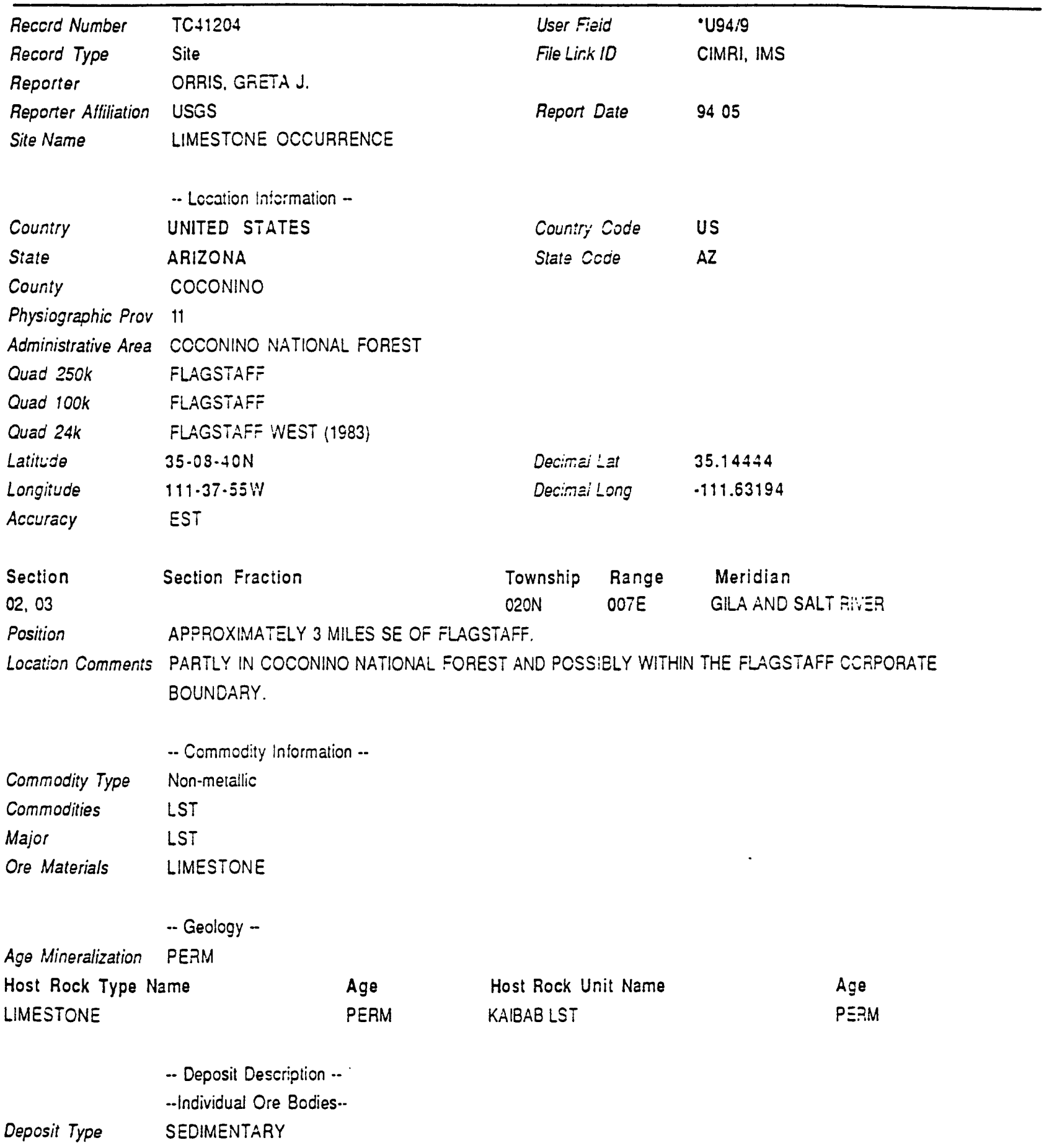

Page 1 
-- Exploration and Development ..

Production Size No

Developent Status Occurrence

- Description of Workings --

- Relerence -

Reference

PHILLIPS, K.A., 1987, ARIZONA INOUSTRIAL MINERÁLS: ARIZONA DEPARTMENT OF MINES AND MINERAL RESOURCES REPORT 4, 185 P.

Prod Comments INACTIVE OCCURRENCE

Page 2 


\section{Mineral Resources Data System (MRDS)}

Report Title

Issue Date 00/00/00

Current Date Monday, April 7, 1997

Number 103 of 103

Record Number T1205

Reccrd Number
Record Type
Reporter
Repcrter Affiliation
Site Name
Country
State
County
Physiographic Prov
Land Status
Administrative Area
Ouad 250k
Ouad 100k
Quad 24k

Latitude

Site

ORRIS, GRETA J.

USGS

WINONA NO. 1

Current Time i0:24:50

Printed 103 of 103

- Location Inicrmation -

$\begin{array}{lll}\text { UNITED STATES } & \text { Country Code } & \text { US } \\ \text { ARIZONA } & \text { State Code } & \text { AZ }\end{array}$

COCONINO

User Field $\quad 94 / 6$

File Link $10 \quad$ CIMRI, IMS

Repori Date 9405

11

46

WALNUT CANYON NATIONAL MONL'NENT

FLAGSTAFF

FLAGSTAFF

FLAGSTAFF EAST

Longitude

$35 \cdot 10 \cdot 27 \mathrm{~N}$

Decim: $\equiv$ Lat

35.17416

$111 \cdot 30-05 \mathrm{~W}$

Decimai Long

$-111.50138$

Acsuracy

EST, $+i-0.5$ MLE

Section Section Fraction

25

Township Range Meridian O21N OO8E

-. Commodity Intormation .-

Commodity Type

Non-melallic

Commodities LST

Major LST

Ore Materials LIMESTONE

-. Geology -

Host Rock Type Name

LIMESTONE

-- Deposit Description -.

--Individual Ore Bodies--

Deposit Type SEDIMENTARY

-- Exploration and Development -.

Production Size

U

Develcpent Status Prospect, Inactive

\section{Age}

PERM

Host Rock Unit Name

KAIBAB LST
Age

PERM 


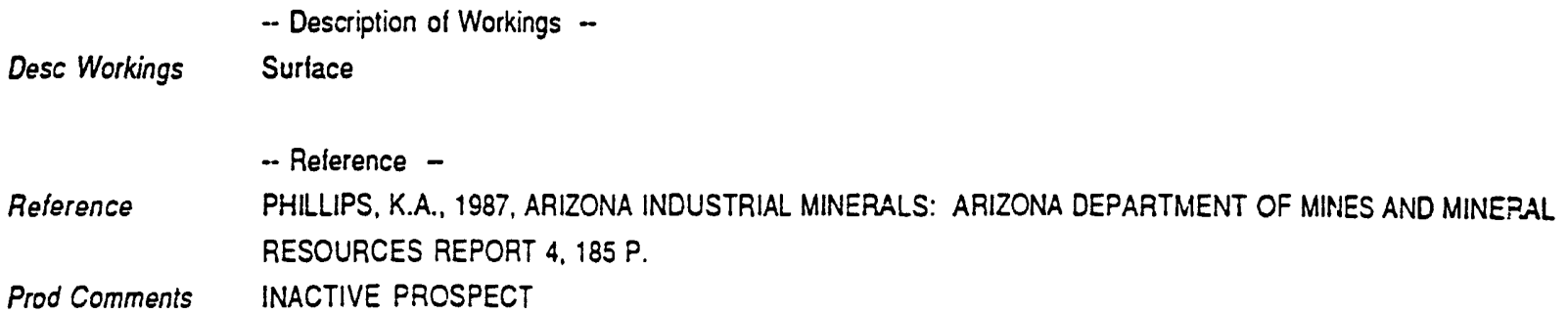

Page 2 